
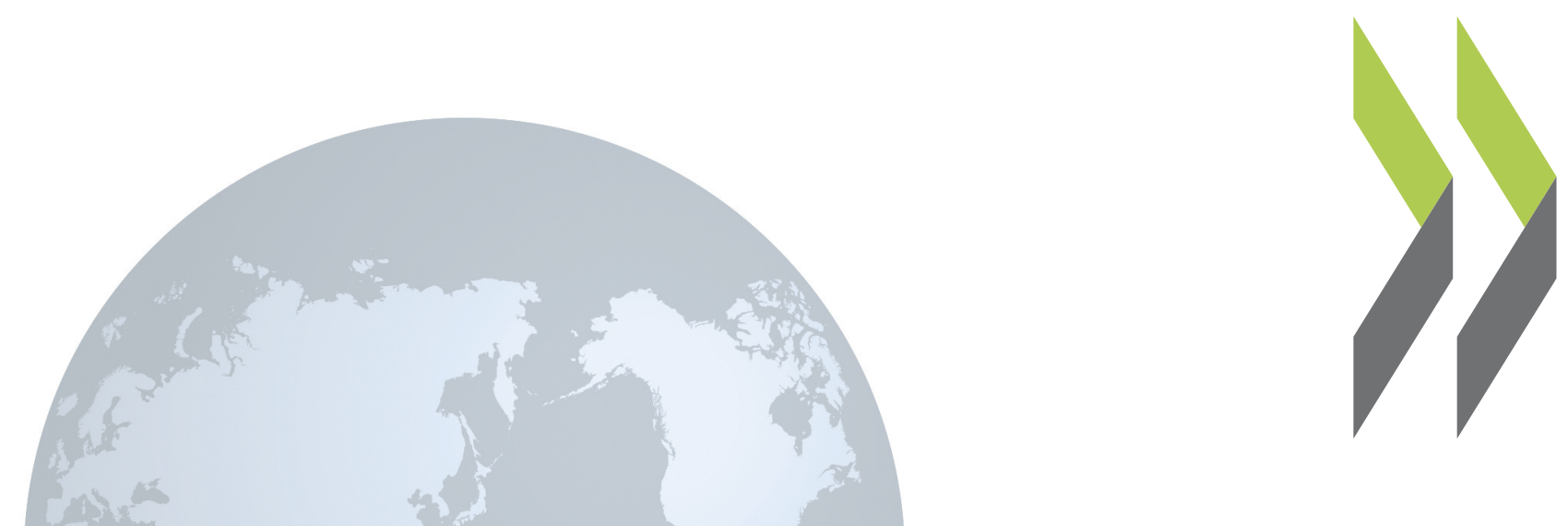

SIGMA Papers No. 23

\title{
Preparing Public Administrations for the European Administrative Space
}

OECD 
Organisation de Coopération et de Développement Economiques

OLIS : 13-May-1998

Organisation for Economic Co-operation and Development

Dist. : 19-May-1998

SIGMA -- A JOINT INITIATIVE OF THE OECD CENTRE FOR CO-OPERATION

Or. Eng.

WITH NON-MEMBER ECONOMIES AND THE EUROPEAN UNION PHARE

PROGRAMME, PRINCIPALLY FINANCED BY PHARE

Cancels \& replaces the same document: sent on OLIS 07-May-1998

\section{PREPARING PUBLIC ADMINISTRATIONS FOR} THE EUROPEAN ADMINISTRATIVE SPACE

SIGMA PAPERS: No. 23 


\section{THE SIGMA PROGRAMME}

SIGMA - Support for Improvement in Governance and Management in Central and Eastern European Countries - is a joint initiative of the OECD Centre for Co-operation with Non-Member Economies and the European Union's Phare Programme. The initiative supports public administration reform efforts in thirteen countries in transition, and is principally financed by Phare.

The Organisation for Economic Co-operation and Development is an intergovernmental organisation of 29 democracies with advanced market economies. The Centre channels the Organisation's advice and assistance over a wide range of economic issues to reforming countries in Central and Eastern Europe and the former Soviet Union. Phare provides grant financing to support its partner countries in Central and Eastern Europe to the stage where they are ready to assume the obligations of membership of the European Union.

Phare and SIGMA serve the same countries: Albania, Bosnia-Herzegovina, Bulgaria, the Czech Republic, Estonia, the Former Yugoslav Republic of Macedonia, Hungary, Latvia, Lithuania, Poland, Romania, Slovakia and Slovenia.

Established in 1992, SIGMA works within the OECD's Public Management Service, which provides information and expert analysis on public management to policy-makers and facilitates contact and exchange of experience amongst public sector managers. SIGMA offers beneficiary countries access to a network of experienced public administrators, comparative information, and technical knowledge connected with the Public Management Service.

SIGMA aims to:

- assist beneficiary countries in their search for good governance to improve administrative efficiency and promote adherence of public sector staff to democratic values, ethics and respect of the rule of law;

- help build up indigenous capacities at the central governmental level to face the challenges of internationalisation and of European Union integration plans; and

- support initiatives of the European Union and other donors to assist beneficiary countries in public administration reform and contribute to co-ordination of donor activities.

Throughout its work, the initiative places a high priority on facilitating co-operation among governments. This practice includes providing logistical support to the formation of networks of public administration practitioners in Central and Eastern Europe, and between these practitioners and their counterparts in other democracies.

SIGMA works in five technical areas: Public Administration Development Strategies; Policy-making, Co-ordination and Regulation; Budgeting and Resource Allocation; Public Service Management; and Administrative Oversight, Financial Control and Audit. In addition, an Information Services Unit disseminates published and on-line materials on public management topics.

\section{Copyright OECD, 1998}

Applications for permission to reproduce or translate all or part of this material should be made to: Head of Publications Service, OECD, 2 rue André-Pascal, 75775 Paris Cedex 16, France.

Views expressed in this publication do not represent official views of the European Commission, OECD Member countries, or the central and eastern European countries participating in the Programme. 


\title{
FOREWORD
}

Preparing Public Administrations for the European Administrative Space contains the papers presented at the multi-country meeting on European integration and administrative reform organised for senior government officials from twelve central and eastern European countries - Albania, Bulgaria, Czech Republic, Estonia, "the former Yugoslav Republic of Macedonia", Hungary, Latvia, Lithuania, Poland, Romania, Slovakia and Slovenia. The meeting was held in Athens on 8-10 October 1997 and hosted by the Greek Ministry of the Interior, Public Administration and Decentralisation and the Greek National Centre of Public Administration.

The meeting provided a forum for central and eastern European countries to exchange views on preparations for European accession, and the important link to public administration reform. Counterparts from European Union Member States were invited to the seminar to share their experiences in these areas, together with experts from the European Commission and SIGMA.

The number of participants in such a meeting is naturally limited, but the subjects discussed are relevant to a larger audience, especially in candidate countries. By widely distributing the papers to public servants and political figures in Central and Eastern Europe, SIGMA hopes to reach those directly involved in helping their countries attain the goal of EU membership. Their task will be long and arduous. A comment which has often been made by EU Member States is that meeting the requirements for accession is often more complicated than countries imagine at the outset and will make increased demands on an already overburdened public service in the midst of great transformation.

This publication contains an overview of the seminar, background papers - including an inventory of how candidate countries plan to manage European integration - as well as ten points which emerged during the panel discussions of senior negotiators. Chapters have been grouped around the three main topics which the seminar addressed: (1) managing EU affairs; (2) membership negotiations and preparation for accession; and (3) preparing to join the emerging "European Administrative Space".

Ensuring the smooth running of a multi-country seminar away from the SIGMA Secretariat required intense organisational and logistical work. The conference facilities provided by the Greek hosts, together with their sharing of information on what is involved in becoming an EU Member State, and on their efforts in administrative reform, contributed to the seminar's success.

SIGMA wishes to thank Nelli Sakellariadou from the Greek Ministry of the Interior, Public Administration and Decentralisation for co-ordinating the event. SIGMA staff Linda Duboscq, Winnie Marshall and Joanne Stoddart provided logistical support, and Michal Ben-Gera, Jacques Fournier and Tony Verheijen developed the programme, wrote background papers and co-chaired the sessions with the Greek hosts. Other background papers and presentations were provided by experts in the field.

For further information, please contact Michal Ben-Gera at the address below.

This publication appears in French under the title Préparation des administrations publiques à l'espace administratif européen.

This report is published on the responsibility of the Secretary-General of the OECD.

\author{
SIGMA-OECD, 2, rue André-Pascal, 75775 Paris, Cedex 16, France \\ Tel. (33.1) 45.24.79.00; Fax (33.1) 45.24.13.00 \\ e-mail: sigma.contact@ oecd.org; http://www.oecd.org/puma/sigmaweb
}




\section{OPENING SPEECH ${ }^{1}$ By Mr. Stavros Benos}

\section{Ladies and Gentlemen,}

It is with great joy that I open the seminar "Administration and European Integration" organised by the SIGMA Programme and hosted by the (Greek) Ministry of the Interior, Public Administration and Decentralisation and the National Centre of Public Administration.

I also wish to convey to you the warm greetings of the Minister of the Interior, Public Administration and Decentralisation, Mr. Papadopoulos, and to ensure you that we fully support the arduous efforts of SIGMA $^{2}$ to create the optimum prerequisites for co-operation and communication with the states of Central and Eastern Europe in the course towards the creation of a great United Europe.

I also feel very happy because this seminar takes place in our country, and thus it gives us the opportunity, in the context of this Forum, to share with the representatives of friendly states in the pre-integration process our own experience from the integration of our country into the European Union and also to listen to their problems, plans and concerns.

We, ladies and gentlemen, share and understand not only the hurdles in the course towards the integration of our states in the European Union but also your visions about a Europe of people, about the great state that will protect our national identities through the development of a unique European conscience common to all of us. Allow me to recall to your memory the fact that Ancient Greece was the birthplace not only of the idea of a harmonious coexistence of states in the context of a big political, economic and social entity, but it is also a country that had put this idea into practice, in a unique manner, within the geographical boundaries of this age.

The role of public administration in the course of European unification emerges as a decisive one, not only because it is linked to institutional and other governmental mechanisms, but also because the real practical, technical and "aesthetic" convergence of different administrative cultures is a key element of European integration.

The means, ladies and gentleman, for the public administration to reach successful results in this process is called public reform. And as this is being planned and implemented by our government, allow me to say

1. Address of Mr. Stavros Benos, Deputy Minister of the Greek Ministry of the Interior, Public Administration and Decentralisation, to the Multi-Country Seminar on European Integration and Public Administration Reform organised by the SIGMA Programme, Athens, 8-10 October 1997.

2. SIGMA is a joint intiative of the OECD Centre for Co-operation with Non-Member Economies and the European Union's Phare Programme. The initiative supports public administration reform efforts in thirteen countries in transition, and is principally financed by Phare. 
not only with the necessary knowledge but also with passion, aiming at an administration that will be up to the standards and requirements not only of a Unified Europe but to Greek citizens' expectations also.

Global interventions that change the administrative map of the country, such as the prefectural local government; the creation of new regions; the unification of local authorities of first degree; new institutions in the service of the citizens, such as the Ombudsman; and changes that make bureaucratic rigid structures and processes flexible constitute the axis on which the administrative reforms are based. And all these are possible through the upgrading of the most precious of resources, that is human resources who work in the administration aiming at reaching the highest qualitative results.

Our experience from the administrative reform in the process of materialisation can provide a constructive contribution to the administrative restructuring of your states.

Firmly believing that the present seminar can be a very important step in this direction, I wish you every success in your work.

Thank you. 


\section{TABLE OF CONTENTS}

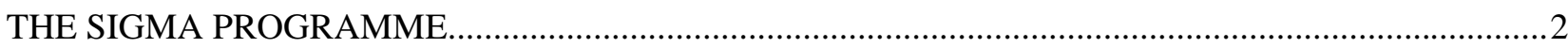

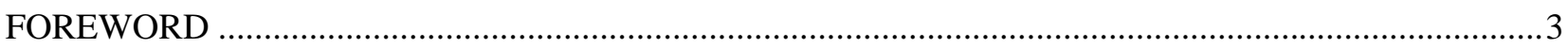

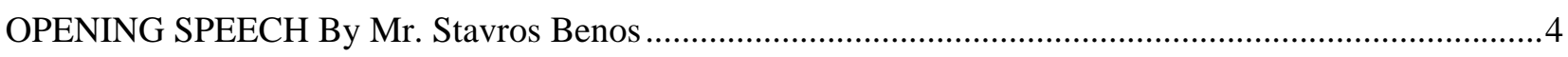

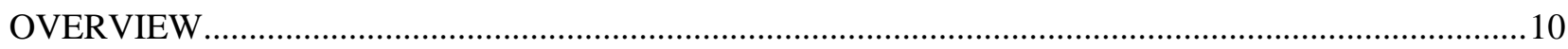

Management and Co-ordination of the EU Accession Process ..........................................................10

The Link Between European Integration and Public Administration Reform ......................................... 13

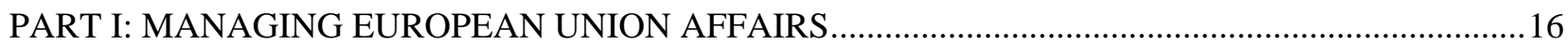

Chapter 1: The Management of EU Affairs in Candidate Member States: Inventory of the Current State of

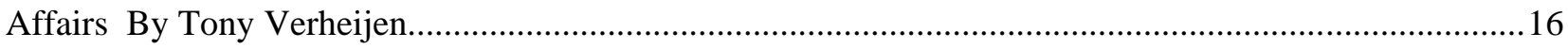

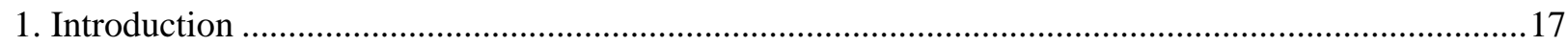

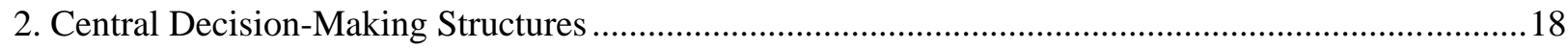

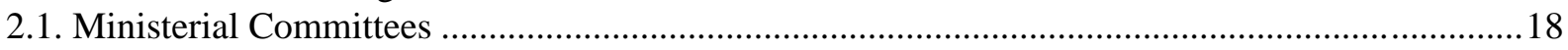

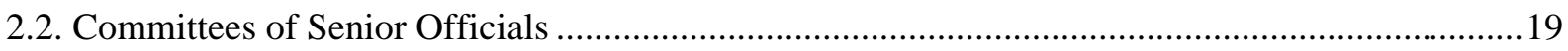

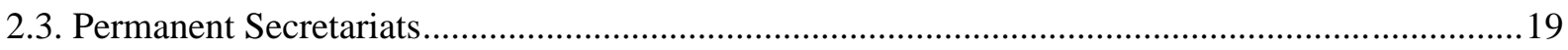

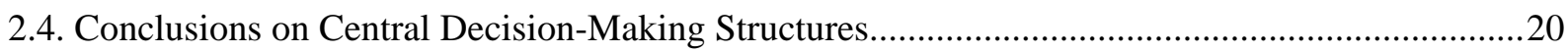

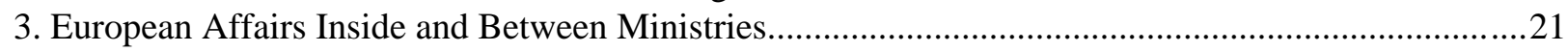

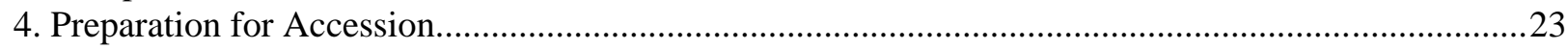

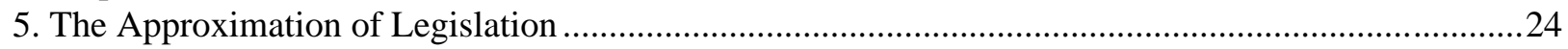

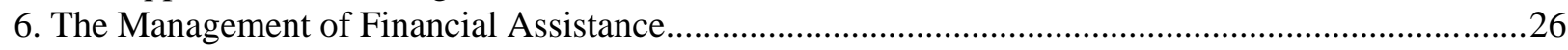

7. Self-Analysis of the System for the Management of EU Affairs......................................................2

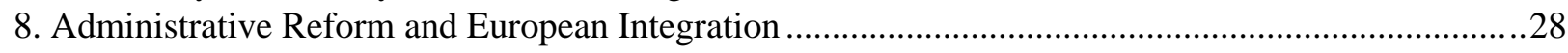

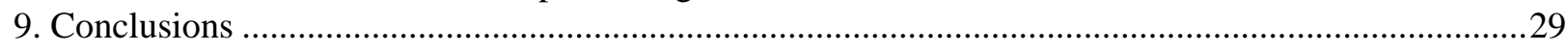

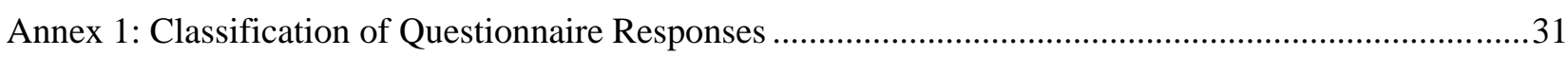

Chapter 2: Meeting the Challenges of Accession By Les Metcalfe …......................................................41

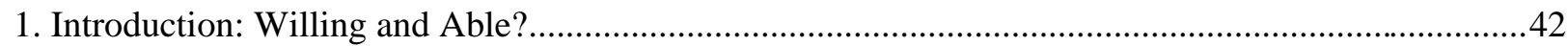

2. Challenges and Capacities — The Internal Management of EU Relations .........................................43

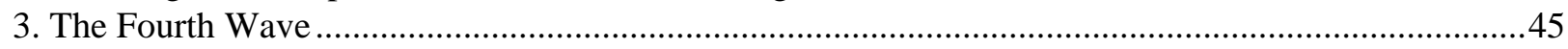

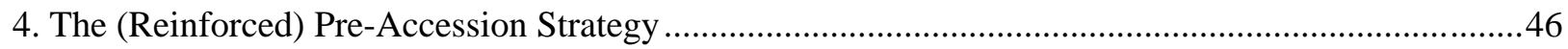

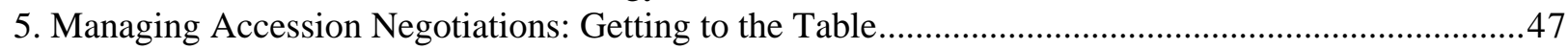

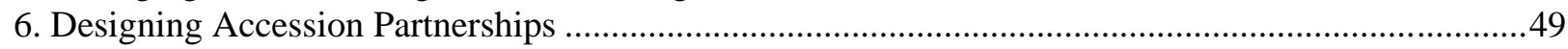

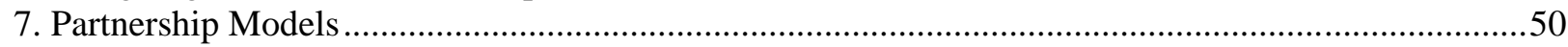

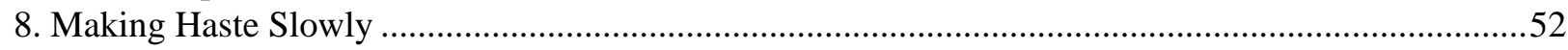

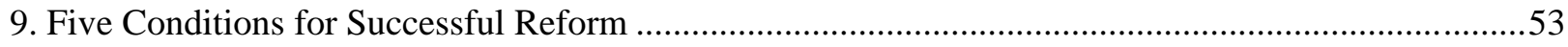




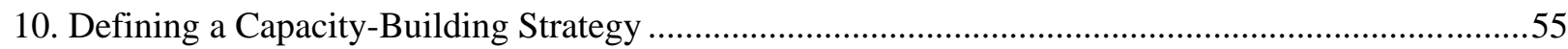

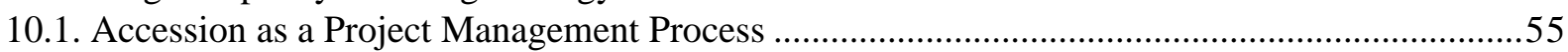

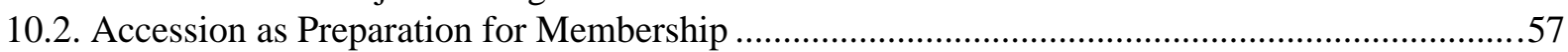

10.3. Managing Accession and Domestic Public Management Reform ..............................................60

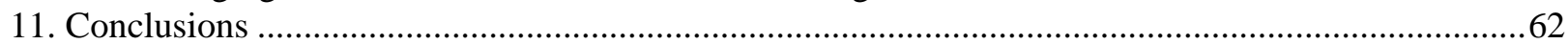

Chapter 3: Transposing Community Directives into the Legislation and Regulations of EU Member States

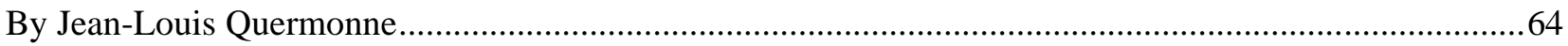

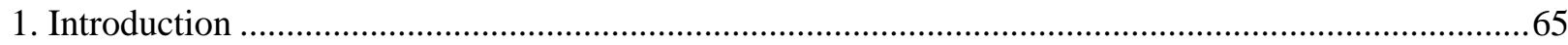

2. Singularity of Directives at the Interface Between Community and Member State Legal Systems ....66

3. Different Ways of Implementing Directives in the Main EU Member States ....................................68

4. Problems Facing Candidate Countries and the European Union on Enlargement of the Community in

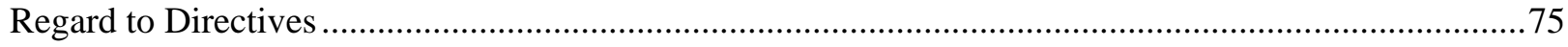

PART II: MEMBERSHIP NEGOTIATIONS AND PREPARATION FOR ACCESSION.........................79

Chapter 4: Preparation of EU and CEEC Institutions for the Accession Negotiations By Alan Mayhew..79

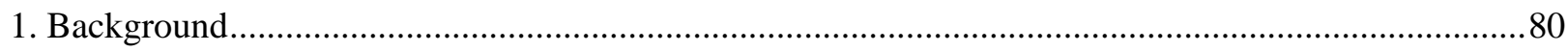

2. Agenda 2000

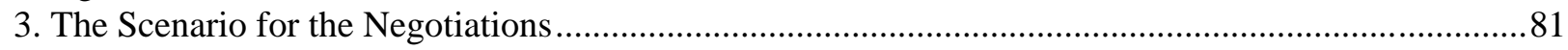

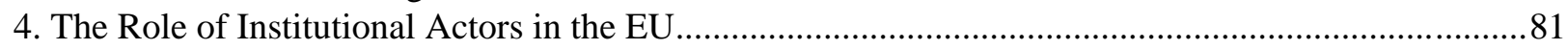

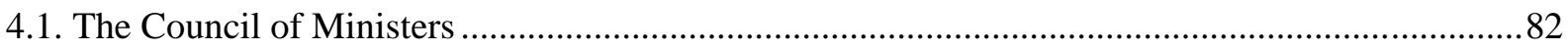

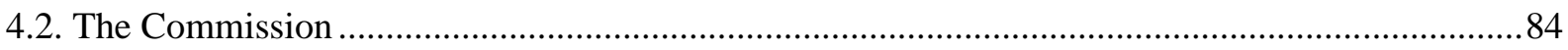

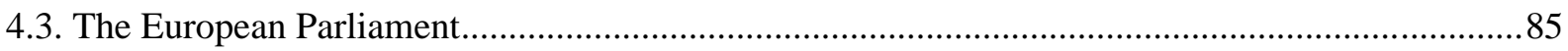

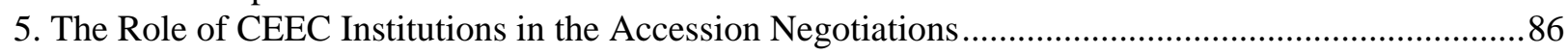

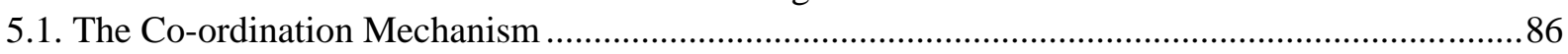

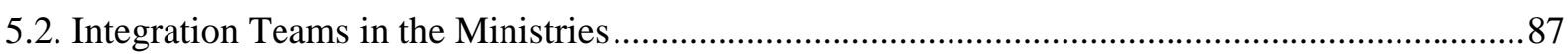

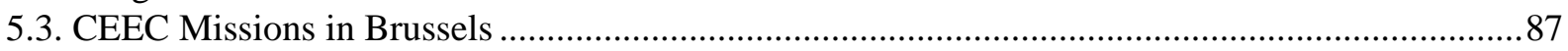

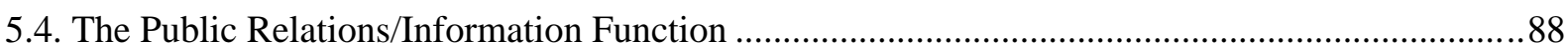

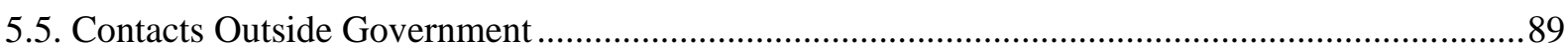

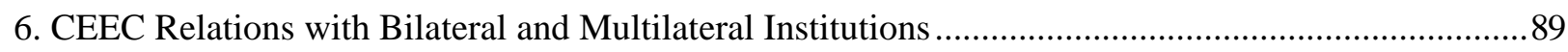

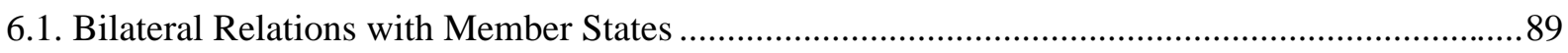

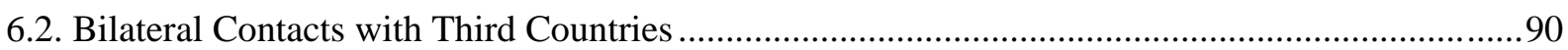

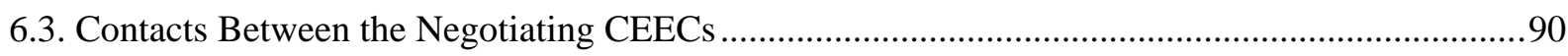

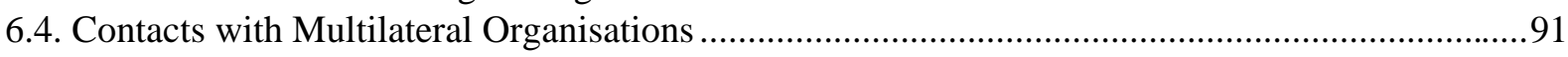

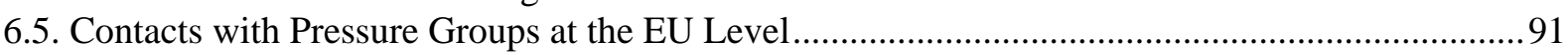

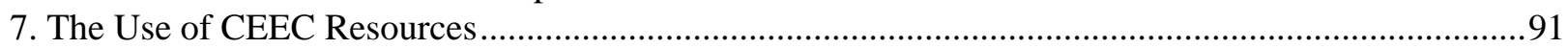

Chapter 5: The European Commission and the Negotiation Process in the Previous Waves of Accession to the European Union By Francisco Grannell .......................................................................................

Table 1. States which Have Put in a Request for Accession to the EU ..................................................95

Chapter 6: Panel of Senior Negotiators: The Main Conclusions By Tony Verheijen ...............................104

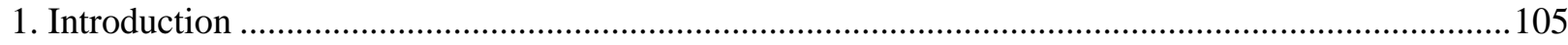

2. Greece

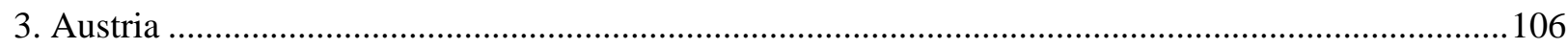

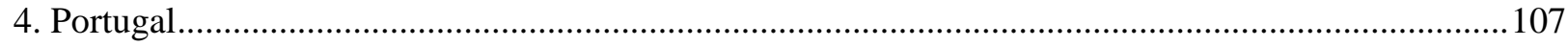

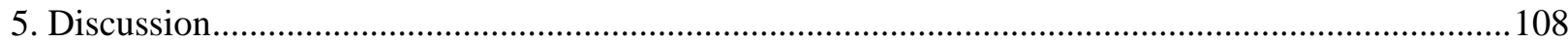


Chapter 7: Administrative Reform in the Commission Opinions Concerning the Accession of the Central and Eastern European Countries to the European Union By Jacques Fournier........................................110

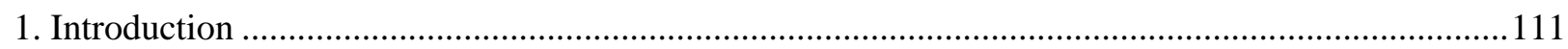

2. The Importance of Public Administration Issues in Commission Opinions.......................................111

3. What Model for Public Institutions Emerges from the Opinions? .................................................111

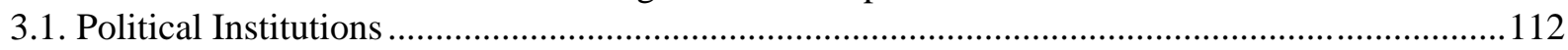

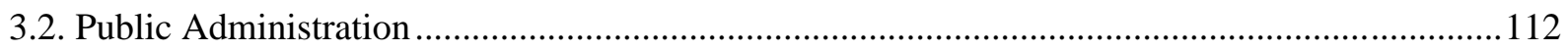

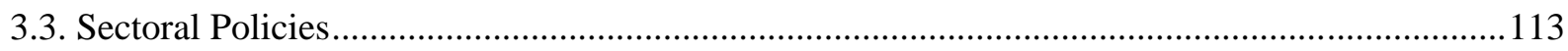

4. How do the Commission Opinions Assess the Public Administration of Candidate Countries? ........114

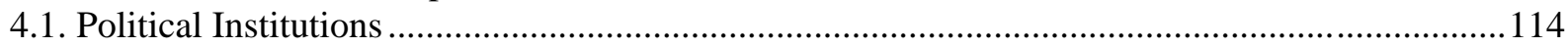

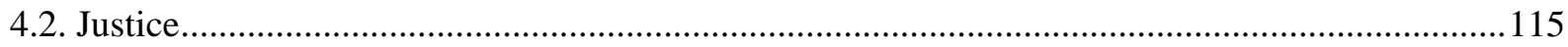

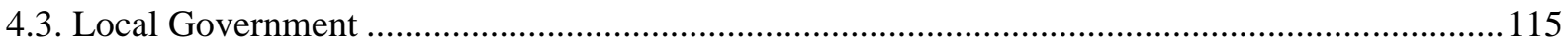

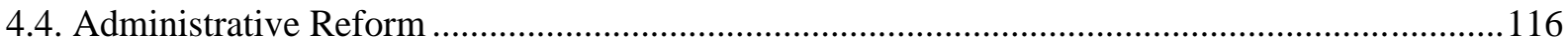

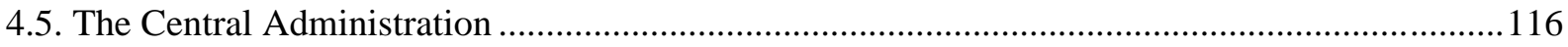

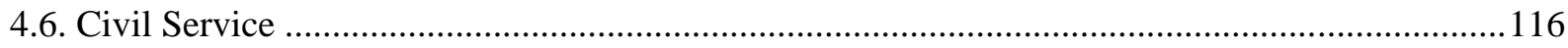

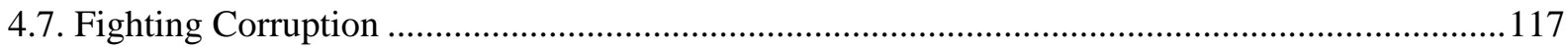

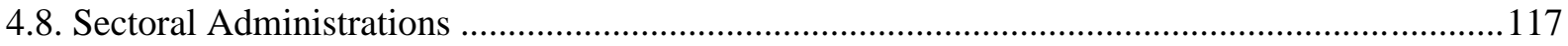

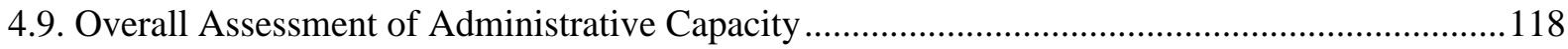

Chapter 8: Governance and European Integration — Reliable Public Administration By Jacques Fournier119

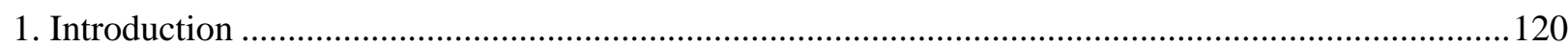

2. Europe and Governance: The European Administrative Space ....................................................... 120

3. The Special Needs of Central and Eastern European Countries in Terms of Public Administration:

Guiding Transition, Fulfilling the Obligations of Membership ........................................................121

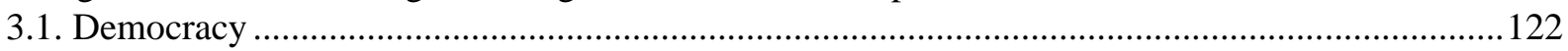

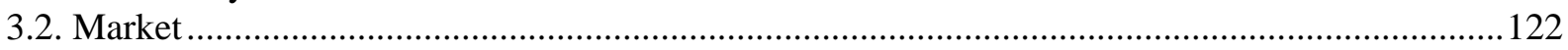

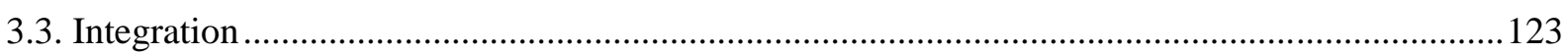

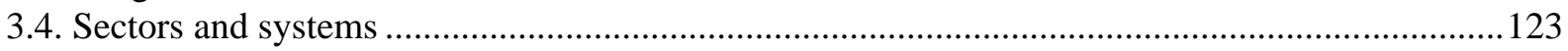

4. A Possible Contribution by Europe to Administrative Reform in Central and Eastern European Countries: Incentives and Models Rather than Coercion.................................................................. 124

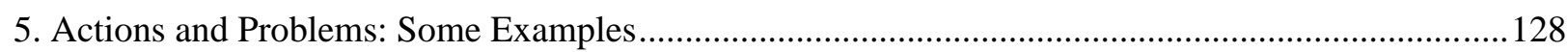

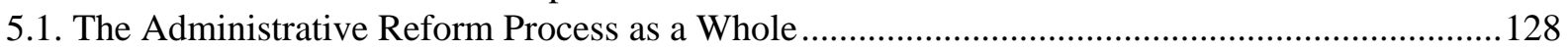

5.2. The Government, National Public Administration, Centralised Decision-Making .....................129

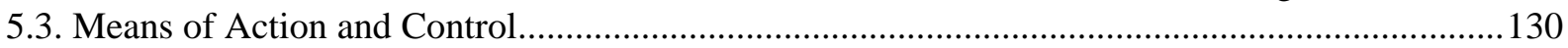

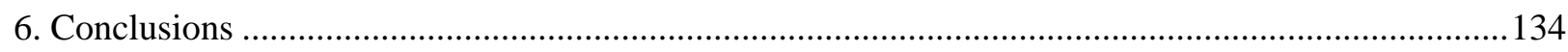

Chapter 9: EU Integration and Civil Service Reform By Jacques Ziller...............................................136

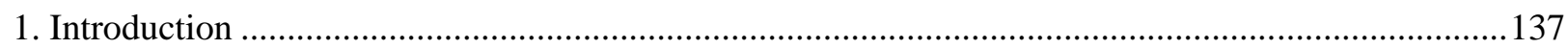

2. Why Would the EU Assess the Civil Service System of a Candidate to Integration?.......................137

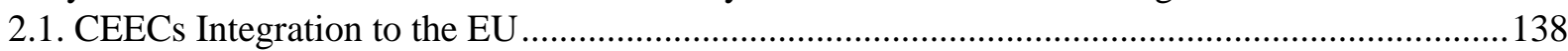

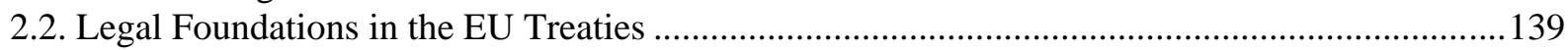

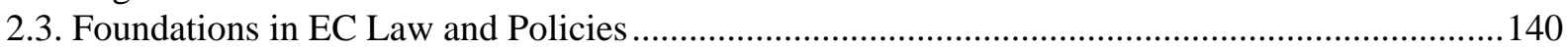

3. The Impact on Civil Services of EU Member States' General Standards .........................................141

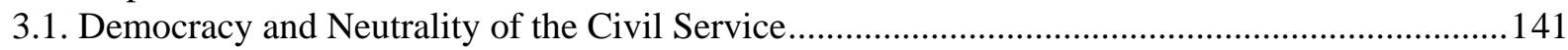

3.2. The Rule of Law as a Foundation of Modern Administration..................................................142

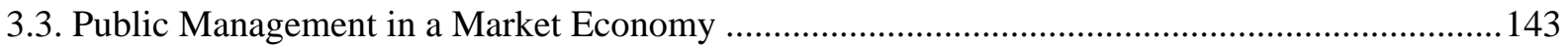

3.4. The Impact of Accession and Participation in the EU on Member States' Civil Services ............143 


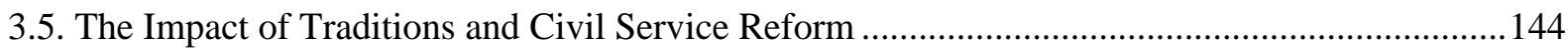

4. Characteristics of Civil Service Systems in EU Member States ....................................................... 145

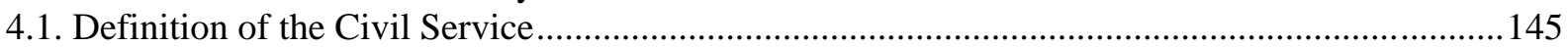

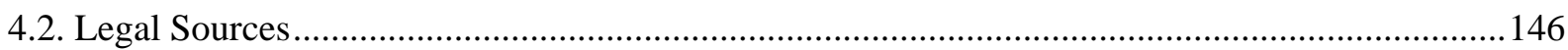

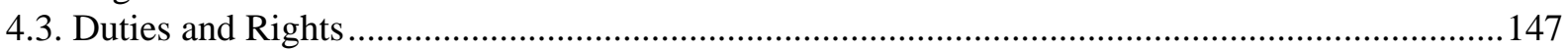

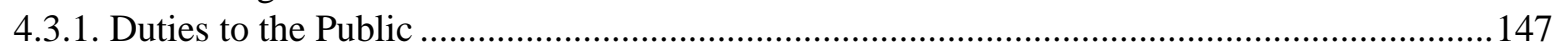

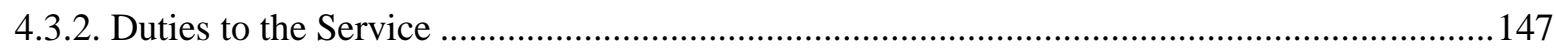

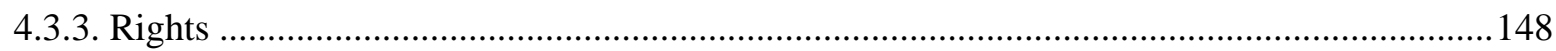

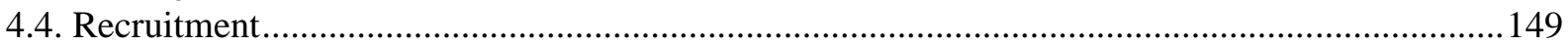

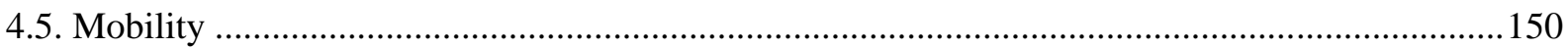

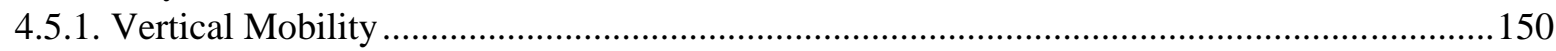

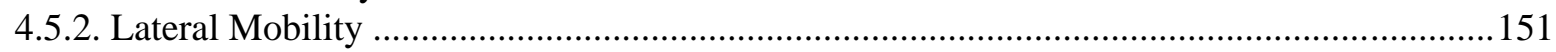

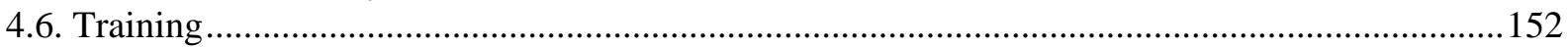

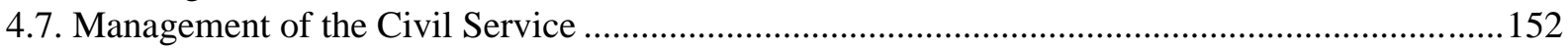

Chapter 10: The Impact of EU Accession on Budgeting, Control and Audit By Kjell Larsson and Richard

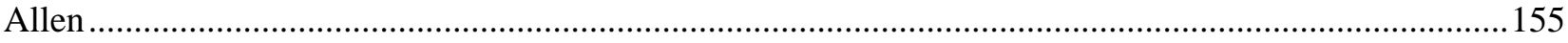

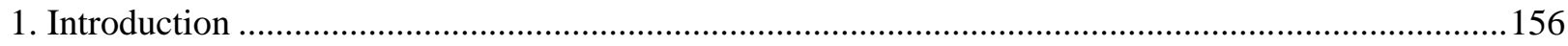

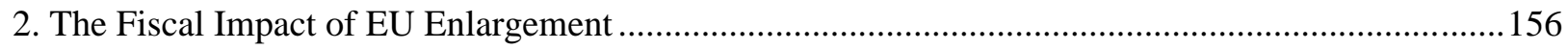

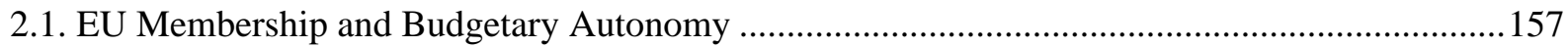

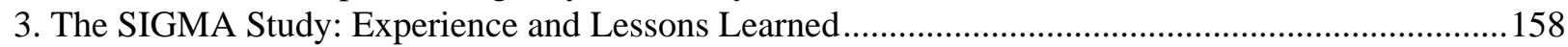

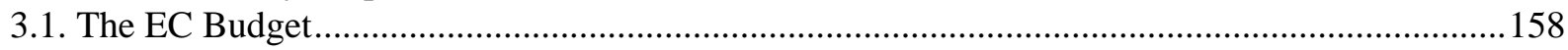

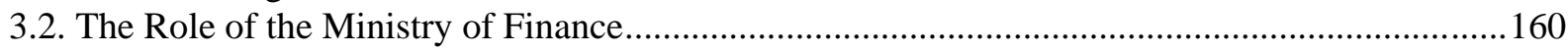

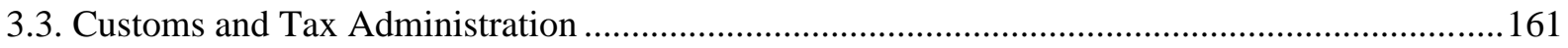

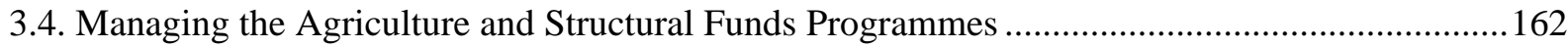

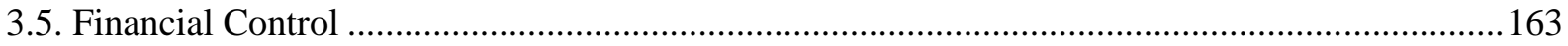

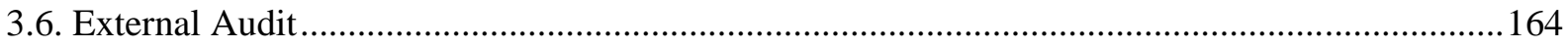

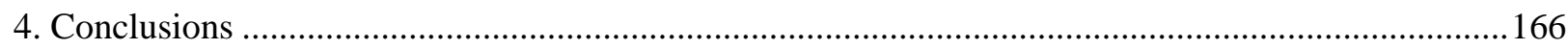

Chapter 11: Rebuilding the State: Administrative Reform in Central and Eastern Europe By Joachim Jens

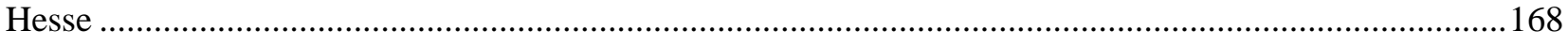

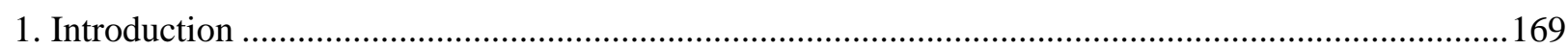

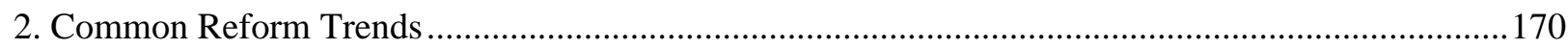

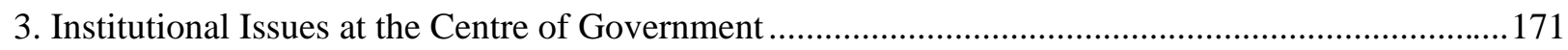

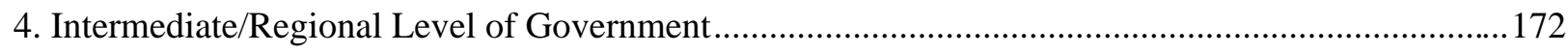

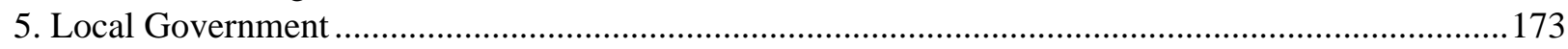

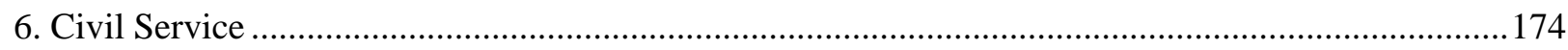

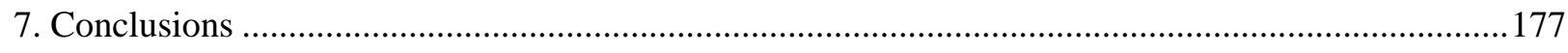

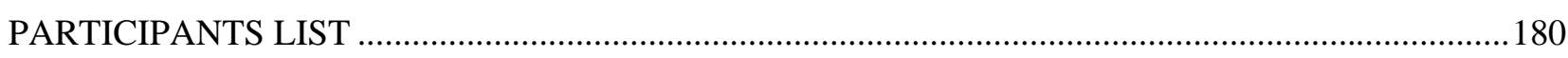




\section{OVERVIEW}

1. The European Commission's avis of July 1997 confirmed that administrative capacity is a crucial ingredient of the readiness to assume the obligations of both becoming and being a European Union Member State. Accordingly, administrative capacity in this regard can be seen as having two inter-linked but distinguishable aspects: the capacity to prepare, co-ordinate and carry out the accession process itself; and the capacity to implement the acquis communautaire and operate effectively within the Union on an on-going basis.

2. To contribute to improved administrative capacity and preparations for accession negotiations of candidate states from Central and Eastern Europe, SIGMA organised a multi-country seminar in Athens on 8-10 October 1997. Senior officials from the ten central and eastern European candidate countries, as well as Albania and "the Former Yugoslav Republic of Macedonia", attended the seminar. The Greek Ministry of the Interior, Public Administration and Decentralisation, and the Greek National Centre of Public Administration, served as hosts.

3. Two aspects of administrative capacity shaped the seminar's themes: first, the management and co-ordination of European integration processes; and second, the relationship between European integration and public administration reform. In both cases, the seminar focused on reviewing and assessing progress to date, and on identifying and clarifying next steps. The meeting took place at a crucial point in the enlargement process, between the publication of the Commission's avis in July, and the European Council meeting in Luxembourg in December 1997.

4. One of the proposals set out by the Commission in the policy document 'Agenda 2000' was to step up assistance to the candidate states. Mr George Zavvos, Counsellor, Directorate General 1A, presented the Commission's new approach towards the provision of technical assistance. He explained that assistance will become accession-driven, and will be delivered in the framework of an Accession Partnership to be concluded which each candidate state. The development of the institutional infrastructure required for being an effective member of the EU will be a major element of these partnership agreements. The exact contents of the individual partnership agreements will be defined on the basis of analyses of current institutional capacities, to be carried out by the Commission and the candidate states. One of the proposed methods of delivering assistance will be twinning ministries of candidate states and current Member States. There will also be an annual assessment of progress toward achievement of the objectives of the plan.

\section{Management and Co-ordination of the EU Accession Process}

a) Taking Stock

5. EU candidate countries have reported considerable progress in the development of institutions and structures for the management of EU affairs. Structures originally set up for the management of the Europe Agreements are being gradually transformed into structures which form the basis for negotiating with the EU and eventually for participating as Member States in the EU policy process. The legal basis 
for the institutional framework has been created in all countries and most of the institutions provided for in legislation have been created. The approach to the development of the institutional framework varies considerably between states. However, one of the interesting aspects of these structures is the emphasis on structures for political decision-making as opposed to administrative preparation. The development of administrative structures for the preparation of policy proposals appears to be the weakest element of the institutional development process.

6. One example of this can be seen with respect to the functioning of the various national systems of inter-ministerial working groups. Whereas the political decision-making structures for EU affairs are relatively permanent, frequent changes have been made in the structure and position of working groups. The answers to the questionnaire give the impression that working group structures remain the weakest link in the institutional system. This is an issue to be reflected on, since inter-ministerial working groups have an important role both in policy formulation on substantive questions, and in contributing to the co-ordination at the level of senior officials.

7. Structures for the management of the approximation of laws are generally well-established. Procedures to ensure compliance of new legislation with EU standards have been put in place, and national strategies for the revision and adaptation of legislation are in the process of implementation. The procedures put in place, however, mostly deal with the process within the administration. Relations between the administration and parliament in the approximation process are not always well developed, which can pose problems, in particular in cases of a coalition government, or when the government does not command a clear majority in parliament. The development of a compliance control system for the whole institutional system is an issue worth discussing.

8. Reflections by officials responsible for EU affairs in the applicant countries reveal a general weakness of the co-ordination capacities in most of their administrations. The same is true for policy implementation, where central and eastern European countries have had to create a new institutional network for policy implementation. This process has not yet been completed in most of the candidate countries, and this affects policy implementation in EU affairs as much as policy implementation in any other area. Candidate countries also have cited a shortage of qualified personnel. This theme surfaced throughout the seminar, especially in the area of preparation for the negotiations themselves.

b)

The Tasks Ahead

9. The seminar's presentations and discussions concerning the negotiations process were carried out within the context of the uncertainty about the results of the Luxembourg European Council. Nevertheless, it was possible to focus on a number of relevant questions that would have to be dealt with regardless of the ultimate plan. [At the time of compiling this SIGMA Paper, the Luxemburg European Council meeting had taken place and Member States had accepted the Commission's recommendation that negotiations begin with five central and eastern European countries, and established a framework for continuing the process with the other five states. Negotiations with Estonia, the Czech Republic, Hungary, Poland and Slovenia began in March 1998.]

10. A theme running throughout the seminar was that the process from becoming an EU Member State to being an EU Member State is an uninterrupted one, and that administrative capacity is crucial before and after membership is achieved. This idea is reflected in the avis, and explains the Commission's emphasis on "Institution Building" as a central element of the accession strategy, and an important focus of financial support for candidates in the coming years. This means that there will be a need to focus not only on the co-ordination of European affairs, and on completing the task of approximation of legislation, 
but on developing the personnel and organisation in key ministries which have responsibility for implementing important parts of the acquis.

11. Greek representatives stressed that it is important for governments to be realistic in drawing up their strategies for the adaptation of national systems to EU requirements. If states move too fast and accept unrealistic deadlines imposed on them, this can have serious consequences once they join the Union. It is therefore important to use techniques like impact analysis to determine a realistic national negotiation strategy, and it is more important to join on realistic terms than to join as soon as possible. The answers to the questionnaire give the impression that relatively little thinking has been done in this area so far.

12. A related issue is that of continuity and stability within the public administration. Institutions take time to develop, and in democratic systems, where governments and coalitions change, there is a need to ensure that such changes do not undermine the institutions and personnel. This is crucial, as a number of speakers noted, for the accession and negotiations process itself. It was emphasised, for example, that membership in the negotiating team, and in the team of officials back in the capital who support the negotiators, must be stable. These officials should not be subject to replacement when the government changes. The teams should be composed of highly qualified individuals who can represent the country throughout a process which normally takes a number of years. As the teams proceed through the negotiations, they develop knowledge, team spirit, relationships in the Commission and with Member State representatives, and a "corporate memory". All this knowledge and experience must not be lost with the inevitable changes of government and of parliamentary majorities.

13. Similarly, the negotiating mandate, and the approach and preparations that the country takes to the negotiations, must not change with the government or the composition of the coalition. Experts who were senior members of their country's negotiating team in previous enlargement rounds underlined that therefore the negotiators' mandate should be seen as a professional matter within the responsibility of the executive, and not be put for decision by the parliament. The parliament's role, on the other hand, would be to ratify the negotiated agreement.

14. Speakers from Member States who shared the experience of their own countries noted the complexity of the European Union, and the resulting complexity of the negotiations process. They emphasised in many ways the importance of building within the administration detailed knowledge of how the EU works, and how things get done. For example, the negotiations process is not only multi-lateral (i.e., the Council of Ministers with all Member States), but also "multi-player", as the Commission, the European Parliament, individual Member States, and even some powerful lobbies all have ways of influencing the content and the progress of the negotiations. A skilled team would need to negotiate with all the players, and have a good understanding of their interests, styles, and political pressures.

15. Nevertheless, and despite all this complexity, all the experienced negotiators agreed that the most difficult element of the negotiations is the "home front". All ministries have activities and interests that would be affected by accession, and all of them should be ready and able to support the team with ongoing information, analysis, and ideas. And they have, at times, to accept that their interests might be part of a compromise that would have to be offered to protect other interests. The pressure and workload would at times be intense, and an immense effort would be required to co-ordinate the process internally. This is why it is not too early for any of the candidate countries to develop and train the teams dealing with European affairs in all the ministries, and to put in place an efficient structure for co-ordination. 


\title{
The Link Between European Integration and Public Administration Reform
}

\author{
a) \\ A Strong Indirect Link
}

16. As accession approaches, the link between European integration and public administration reform seems to become stronger. Significantly, the European Commission places great emphasis in the avis on the capacity of Member States' administrations to implement the body of European law (the acquis communautaire) on schedule, although this had never been an issue in previous waves of accessions.

17. The link is an indirect one since there is no general body of European law in the public administration sphere. Just as individual Member States are free to frame their own constitution, they are free to organise their administration as they see fit. This is an issue that comes under the subsidiarity principle. In actual fact, public administration structures and regulations vary a great deal among the present EU Member States. All of them jealously guard their independence on this issue. That they should refuse to recognise an applicant's right to the same independence is unthinkable.

18. Indirect though it may be, the link between accession and public administration reform is nonetheless very real. Member States must be able to implement EU policies and legislation in their own countries. To do so, they must have an administration that performs well. This is a very important requirement for the EU as a whole and for its individual Member States. The Union has no administration at individual country level and therefore relies on each Member State to implement its decisions. In the same way, the individual Member States depend on each other to implement Community regulations, for example, on product health standards or the qualifications required to practise certain professions.

19. The EU administration is in fact a chain of national administrations. That chain - as we have seen with external border controls - is only as strong as its weakest link. While candidate countries are not under any requirement as to the means they use (no-one dictates how they should organise their administration), they do have to satisfy what lawyers call "performance requirements" or "obligation of results".

20. Central and eastern European countries have made great progress on public administration reform. Several countries have defined an overall reform strategy. Almost every country has made an effort to organise government affairs efficiently and to improve decision-making processes. Legislation on the civil service has already been introduced or is in the process of being drafted. Regulations on taxation and public procurement have been clarified. Internal and external checks and balances have been put in place. In short, the main elements of the rule of law in a democratic system are being put in place.

21. However, there is still a long way to go before candidate countries build the capacity to implement the entire body of Community legislation. In this respect, an analysis of the Commission's opinions is instructive. The Commission, as its mandate required, closely reviewed the situation in Community policy areas (the regulation of competition, telecommunications, indirect taxation, veterinary and plant health controls, transport, labour inspection, environment, consumer protection, border controls, international police/judicial co-operation, customs, financial audits, etc.). It found serious inadequacies in most of them.

22. Apart from these sector-specific inadequacies, other more general criticism emerged, although the Commission was careful not to impose a model: a lack of a coherent overall plan for administrative reform in several countries; poor legislation, resources and morale in the civil service; failures in inter-ministerial co-ordination; and weaknesses in the fight against fraud, corruption and crime. 
23. On that basis, the overall assessment was both careful and nuanced. No country applying for membership is judged perfectly capable of applying European law in the medium term. However, four are considered likely to be capable, and the other six possibly capable. In other words, all applicant countries need to pursue their reform effort.

24. The process that is being put in place in 1998 for accession negotiations includes significant attention to problems in public administration. As we know, there will be three stages to the process: Accession Partnerships, for which the general framework will be established at Community level; national programmes for the adoption of EU legislation that applicants are committed to; and lastly, Institution Building Plans which will outline the action to be taken on public administration.

25. Participants at the seminar in Athens identified these priorities that were essential for a successful pre-accession phase.

26. First, it is crucial for the countries concerned to be able to retain control over the reform of their public administration. As someone said at the Athens Seminar, the countries themselves must be the "driving force" behind reform. This is in line with the principles governing relations between EU Member States. It is also common sense. Reform can only work if it is based on perfect local knowledge of the country concerned and if those who will be implementing reform take ownership of it.

27. The second key to success is strong political determination, in the form of a comprehensive government action plan and proper structures to guide its implementation.

28. In both current and aspiring EU Member States, administrative reform does not always arouse interest among politicians, either because they underestimate what is in fact the vital role played by government in a market economy, or because they are put off by awkward issues that do not always produce spectacular results. In the pre-accession phase there is no longer room for any lack of interest. Every government is now aware that this is an important issue. It is up to them to tackle it in the right way.

29. The third priority identified was the need to strike a balance between the horizontal and the sectoral approach to administrative reform. The European Commission will probably emphasise, in line with its mandate, actions required in each sector to apply the acquis. Many of the support and twinning initiatives being planned by the Commission will be given over to this.

30. However, sectoral issues should not mask the broader picture. Of course the legal frameworks for agricultural, environmental or telecommunications policy have to be established. It is advisable to have police, customs and veterinary services that operate correctly in terms of both quantity and quality, but this cannot be achieved in isolation. It will only succeed if a number of general systems have been set up or re-organised - inter-ministerial co-ordination, government decision-making, civil service regulations and management, budget procedures and control mechanisms - to ensure the smooth running of the public administration.

31. The substance of policy should of course be left to the individual country to decide. This said, and this is a last important priority, applicant countries could usefully explore the solutions adopted in other countries that share with them common values regarding the rule of law, democracy and the market economy. 
32. It is clear that a "European Administrative Space" is now beginning to emerge. The gradual emergence of this "space", which does not impose standards, is a logical step forward in the construction of the European Union. National governments meet, compare notes and join forces to draw up and enforce EU standards. It is quite natural that they should increasingly influence each other.

33. In each sphere of administrative policy, it offers applicant countries a range of solutions that are similar enough to provide some common ground and broad enough to leave each country substantial room for manoeuvre in terms of policy options. 
PART I: MANAGING EUROPEAN UNION AFFAIRS

Chapter 1: The Management of EU Affairs in Candidate Member States: Inventory of the Current State of Affairs

By Tony Verheijen ${ }^{3}$

3. Tony Verheijen is currently Administrator, Policy-Making, Co-ordination and Regulation, at SIGMA in Paris. $\mathrm{He}$ is on leave from his post as Lecturer in Public Administration and European Integration at the University of Limerick, Ireland. 


\section{Introduction}

34. This paper provides an overview of the responses to the SIGMA questionnaire on structures for the management of European Union (EU) affairs sent to the ten central and eastern European candidate Member States in June 1997. Nine countries responded to the questionnaire. Due to the ongoing reform of the system for the management of EU affairs in Slovenia, it was impossible for the Slovenian authorities to respond to the questionnaire. Therefore only some very limited information has been included on Slovenia.

35. The development of structures for the management of EU affairs in the states of Central and Eastern Europe is at a critical stage. In recent years, structures which were originally designed for the implementation of the Europe Agreements have gradually been transformed into structures for the management of EU affairs in the pre-accession period. The pre-accession period imposes considerable requirements on the institutions of candidate Member States. The process of approximation of laws has to be extended beyond the requirements of the Europe Agreements to meet the requirements of the Cannes White Paper. The full acquis communautaire has to be transposed and implemented. Furthermore, detailed institutional requirements, which were not part of the Europe Agreements, have been included in the Cannes White Paper, in addition to the institutional elements of the general membership criteria set out at the Copenhagen Summit. These detailed requirements related in particular to policy implementation structures and the development of financial control mechanisms. Finally, candidate Member States have to develop the structures and procedures for the preparation of national positions for the membership negotiation process. The development of new institutions, structures and procedures for the process of European integration takes place under conditions of institutional turbulence; the central and local state institutions of most central and eastern European countries are in the process of being re-constructed.

36. The importance of having a well-functioning institutional framework for the management of EU affairs during the pre-accession period should not be underestimated. The quality of the institutions, structures and procedures created will influence the timetable for membership, taking into consideration the conditions set out in avis, and the conditions under which membership will be granted, i.e. the extent to which the accession treaty will reflect the real economic and political conditions in the country.

37. In many ways this is an appropriate moment to evaluate the state of development of the systems for management of EU affairs in Central and Eastern Europe. Just after the publication of the avis and before the start of negotiations, there is a brief period to reflect on the structures and procedures in place and to ensure that all the components of the negotiation and implementation engine are in good shape for the long trip on the treacherous road towards EU membership.

38. The purpose of this paper is to serve as a basis for discussion of the development of systems for the management of EU affairs in central and eastern European countries, and how this relates to the overall institutional and administrative reform process. Obviously, it is only possible to draw conclusions about the structures as they are described in the response to the questionnaire. It is not possible to discuss how well these structures function in practice, apart from the limited information obtained on the basis of the self-analysis which the countries were asked to conduct.

39. The analysis of the information arising from the answers to the questionnaire is subdivided into seven main sections: central decision-making structures; ministerial and inter-ministerial structures; the management of the accession process; the management of the approximation of legislation; the management of financial assistance; the relations between administrative reform; and European 
integration, and the self-analysis of strengths and weaknesses of institutional structures for the management of EU affairs.

\section{Central Decision-Making Structures}

40. The creation of central decision-making structures is well advanced in all central and eastern European candidate Member States. The legal basis for the creation of decision-making structures is in place in all countries, even though not all the institutions have actually been set up. There is considerable variety in the central decision-making structures which have been created. It is important to note that the systems for decision-making in EU affairs have not been permanent. Changes in government have often resulted in a complete overhaul of governmental structures, including the structures for the management of EU affairs, and there is no guarantee that the structures described in this paper will outlast the next elections in any of the candidate Member States. However, with the start of membership negotiations approaching, frequent and radical changes in decision-making structures in EU affairs are less likely to occur. Another factor which might lead to some form of stabilisation of policy-making structures are the clear indications in the avis that the European Commission would like to see a stabilisation and strengthening of the structures for decision-making in EU affairs.

\subsection{Ministerial Committees}

41. The central institutions for decision-making in EU affairs can be described as follows. At the highest level, there is in most countries a ministerial committee, which decides on European integration policy and, with the exception of a few countries, has powers to resolve inter-ministerial conflicts in the final instance. This, of course, does not preclude the discussion of EU affairs in general council of ministers meetings. There are significant differences in the composition of the ministerial committees. The following are the main patterns which can be observed:

- Ministerial committees with limited membership, with or without the possibility of including other ministers and members of other state institutions if required (Czech Republic, Estonia, Hungary, Latvia, Poland,);

- Ministerial committees with varying membership, including at least all ministers responsible for policy areas which are affected by the European integration process (Romania);

- Two countries which fall outside these patterns are Bulgaria and Slovakia. Bulgaria has special monthly Council of Ministers' sessions on European integration to discuss policy, strategy and appointments, and a committee at the level of deputy ministers which deals with day-to-day management and implementation There is no specialised ministerial committee for EU affairs. In Slovakia an Advisory Council on European integration has been created. However, this body has a purely advisory function and does not have the same status as the ministerial committees described above. While in Bulgaria provisions have been made for the creation of a committee of senior officials, no such structure was reported by Slovakia.

42. The Prime Minister plays a central role in the European integration policy process in all countries, illustrating the strategic importance attributed to European integration. Ministerial committees on EU affairs are generally chaired by the prime minister. In some countries, the prime minister is assisted by a minister or secretary of state for European integration, who generally reports to the prime minister. Ministers of European integration usually head the European secretariat or bureau, to be discussed below. The main exception to the rule is Lithuania, which has a Ministry of European Affairs that in addition 
shares the administrative responsibility for EU affairs with the Ministry of Foreign Affairs. In Slovenia, the definition of the specific responsibilities of the recently nominated Minister for European Affairs are to be defined in a Government Decree which is under preparation.

43. Decisions in ministerial committees are generally taken by consensus, even though in Lithuania and Poland ministerial committees can decide by majority or qualified majority respectively. In Hungary, decisions are generally taken by voting.

\subsection{Committees of Senior Officials}

44. Most countries have created committees of senior officials to manage the EU policy process at the level of senior civil servants or deputy ministers. Bulgaria has two committees: the Council for European Integration, which brings together deputy ministers, and a committee of senior civil servants, which consists of heads of EU divisions in line ministries. Romania does not have a formal (permanent) committee of senior civil servants; meetings of officials are called on an ad hoc basis when the need arises. Slovakia did not report provisions for the creation of a committee of senior officials. Meetings of senior officials generally have a preparatory function (in Bulgaria preparation of policy proposals is carried out by the Council for European Integration) and also serve to filter issues. The case of Lithuania is particularly interesting. The newly created Committee of Deputy Ministers, the Delegation for the Preparation of EU Membership Negotiations, is specially geared towards the preparation for membership, even though it also has tasks related to the preparation of meetings of the ministerial committee on European integration.

45. The (almost) general lack of co-ordination committees which bring together the civil servants who head EU divisions in the line ministries is striking. The creation of committees at this level of the administration could make a major contribution to the improvement of co-ordination capacities in policy-making on EU affairs.

\subsection{Permanent Secretariats}

46. The position of the permanent secretariat for EU affairs varies considerably between countries. In one group of countries, the permanent secretariat is part of the centre of government (Estonia, Romania, Slovenia and Slovakia [the main secretariat, a smaller secretariat exists in the Ministry of Foreign Affairs to deal with the management of Association Council and Committee meetings]) or an independent administrative unit linked to the Centre of Government (Latvia and Poland). The subordination of the European Secretariat to the Centre of Government in Slovenia is a recent development. The Slovenian Parliament recently nominated a Minister for European Affairs without portfolio, as a consequence of which the Office for European Integration, which used to be part of the Ministry of Foreign Affairs, is now directly attached to the Prime Minister's Office.

47. In other countries the European integration secretariat is hosted by the ministry of foreign affairs. The Czech Republic does not have a formal European Secretariat. However, the Czech Department for the Co-ordination of Relations with the EU at the Ministry of Foreign Affairs fulfils most of the tasks which are carried out by the European secretariats in the other central and eastern European countries. Another part of the preparatory and co-ordination work is carried out by the Czech Department of Political Relations with the EU, also at the Ministry of Foreign Affairs. In Bulgaria, the Ministry of Foreign Affairs controls the European Secretariat, which was recently transferred from the Council of Ministers. In Hungary, the Secretariat used to be split between the Prime Minister's Office (Secretariat to 
the Cabinet for European Integration) and the Ministry of Foreign Affairs. The decision has been taken to transfer the secretariat of the Cabinet for European Integration to the Ministry of Foreign Affairs, so that all administrative support functions for the European integration process are located at this ministry. In Lithuania there are two Secretariats, one in the Ministry of Foreign Affairs and one in the Ministry of European Affairs, with the former playing the more important role.

48. Secretariats generally fulfil preparatory tasks but also monitor policy implementation and can function as a strategic planning unit. In some countries, the European secretariat also acts as a clearing house for legislation, ensuring the compatibility of new legislative proposals with European standards (Latvia, Poland, Romania [shared with the Legislative Council and the Ministry of Justice)]. The creation and management of working groups is another task the secretariat has assumed in some countries, as well as communications with the public and the co-ordination of training in EU affairs. The latter two tasks were mentioned in nearly all countries which had responded to the questionnaire by early September 1997.

49. The number of staff working for the European secretariats varies significantly between countries. The following is an overview of staff numbers reported in August/September 1997 (with updated information where available as at February 1998). The Polish Office of the Committee for European Integration, for instance, has a staff of 160, while the Estonian has no more than six permanent and 3-5 temporary (Estonian and foreign) staff. Staff levels in other secretariats number 100 in Hungary, 40 in Romania (to be expanded to 70), 37 in Lithuania (the total number for the European Integration Departments for the ministries of Foreign Affairs and European Affairs), 20 in Bulgaria (only shortly after the creation of the Department, expected to expand), 20 in the Czech Republic (in the two departments, in the process of being expanded), 17 in Latvia (25 as at February 1998) and 16 in Slovakia (including the European Integration Department at the Ministry of Foreign Affairs). The size of the administration in the country alone does not provide a sufficient explanation for the difference in numbers. It is important to keep in mind that smaller countries have to deal with the same workload in EU affairs as bigger countries, and can therefore normally be expected to have larger European integration offices relative to their size. This appears for the time being not to be reflected in the numerical strength of the European integration offices in the smaller countries, in particular in two of the Baltic states. Obviously, a high level of decentralisation of the management of EU affairs could compensate in part for a lack of staff in the central secretariat, but there is a minimum level of staff required for the adequate co-ordination of policy-making and implementation, and in view of this, staff levels might not be sufficient in some of the candidate Member States.

\subsection{Conclusions on Central Decision-Making Structures}

50. The responses to the questionnaire raise a number of questions. A first question regards the division of labour between ministries, in particular the role of the ministries of foreign affairs. Traditionally, ministries of foreign affairs have often been assigned responsibility to manage EU affairs, as this was considered to be a foreign policy issue. Even though the perception of the character of EU affairs as a policy area has changed, the ministry of foreign affairs still plays a central role in EU policy co-ordination in many EU Member States, for reasons of tradition and possibly because ministries of foreign affairs are seen as "neutral" in inter-ministerial conflicts. In recent years, however, there have been moves to increase the role of other ministries, in particular ministries of economic affairs and newly created ministries of European affairs in the EU policy process, at the expense of the role of ministries of foreign affairs. The question of how to classify EU affairs and to what ministry to assign responsibility is an important one. It is interesting to note that a number of central and eastern European candidate Members have given the Minister of Foreign Affairs a central role in the management of EU affairs 
(Bulgaria, the Czech Republic and Hungary). In Lithuania, the Ministry of European Affairs has gradually increased its role in the management of EU affairs, but the main European Secretariat is still part of the Ministry of Foreign Affairs. In Slovakia, the main European Secretariat is at the Government Office but the Ministry of Foreign Affairs plays a significant role in the management of the Association Agreement. In the other countries, in particular in Estonia, Latvia, Poland, Romania and Slovakia, the role of the ministry of foreign affairs is less central. In these countries, the main institution in the management of EU affairs is either part of the centre of government (council of ministers or government office) or an independent unit in the administration (Latvia and Poland).

51. Ministries of foreign affairs in all countries which responded to the questionnaire have the task to maintain the links with the mission to the EU and to staff the missions. However, the role of ministries of foreign affairs in staffing the missions might be reduced when countries join the EU. The transformation from mission to permanent representation usually goes with the development of a more diverse institution, staffed with civil servants representing different ministries. Provisions for this have already been made in several countries. The long-term role for ministries of foreign affairs in the management of EU affairs remains a question to be addressed.

52. The same question can be raised regarding the role of ministries of trade and/or economic affairs. In EU Member States, the economic ministries have become increasingly involved in EU policy co-ordination, especially when policy-making on internal market issues is concerned. Economic ministries in Central and Eastern Europe are so far largely absent from the central institutions for EU policy-making. The important role assigned to ministries of justice should be noted. This can easily be explained as a consequence of the high priority accorded to the management of the approximation of legislation, which is a central issue in the pre-accession period. The importance of ministries of justice in Central and Eastern Europe is interesting in particular considering the limited role of ministries of justice in EU affairs in Member States, regardless of recent attempts to extend their influence (e.g. in the Netherlands).

53. A last point of interest is how the general government debate on European integration will develop. Since European integration will eventually affect most or all ministries, it is important to keep those ministries not represented in the ministerial committee involved in the policy debate. The Bulgarian decision-making structure provides for special sessions of the Council of Ministers on EU affairs. It will be interesting to see how these special sessions on European integration will influence the development of a coherent European integration strategy in Bulgaria and whether this example will be followed by other countries.

\section{European Affairs Inside and Between Ministries}

54. Central decision-making bodies represent only the tip of the iceberg in the policy process. European integration policy is no exception to this. The strength of central institutions and their abilities to develop strategic capacities depend to a large extent on whether their workload allows them time to develop strategies and overall policy. One of the main problems of administrative systems in Central and Eastern Europe, as noted in the European Commission avis and in other analyses, is the weakness of the policy co-ordination systems. This leads to many issues and inter-ministerial conflicts being pushed up to central government bodies for their resolution. This in turn limits the time centres of government can devote to the development of policy and strategy.

55. Most central and eastern European countries are well advanced in the creation of European integration policy units in individual ministries. In most countries, it is mandatory for ministries to have a specialised unit for European integration issues, even though in most cases there is no unified approach to 
the creation of such units. Furthermore, as has been mentioned in the section on committees of senior officials, in most countries there is no framework for regular meetings between the heads of European integration policy units. The creation of a framework for regular meetings could make an important contribution to the improvement of co-ordination capacities in the countries.

56. The implementation of EU policies and legislation has started to increasingly affect sub-national government (e.g. the implementation of public procurement directives, management of structural fund projects, etc.). Therefore the early creation of specialised units at sub-national level would be an important step forward in the creation of institutional structures for the management of European affairs. In Romania each prefecture (de-concentrated general unit of state administration) is also required to have a specialised unit for European integration. However, generally there is still too little awareness of the importance of the integration of de-concentrated units of the state administration and local self-governing authorities in the management of EU affairs.

57. The creation of a well-functioning system of inter-ministerial policy co-ordination can alleviate the pressure on centres of government. All central and eastern European countries have made provisions for the development of a network of inter-ministerial working groups. There is no clear pattern in the structure of the network of working groups existing in the different countries, and the existing structures are not necessarily permanent. The organisation of working groups either follows an external or an internal logic. Countries that have organised their working group structures according to external criteria generally either follow the sub-division of the European Commission questionnaire or the structure of the Cannes White Paper. Variations on this system exist as well. Romania, for instance, operates separate working group structures for the implementation of the recommendations of the White Paper (23 working groups) and the Europe Agreement (9 working groups). In Hungary, there are 27 working groups set up according to the European Commission questionnaire, plus four additional groups set up for internal purposes. In the Czech Republic, the 22 working groups are organised on the basis of the requirements posed by the management of the implementation of the Europe Agreement. When working groups are organised on the basis of an internal logic it is left to individual ministries to decide on the creation and management of working groups.

58. An important question in relation to the system of working groups is which institution is responsible for the creation and co-ordination of working groups. Working groups can either be created on the initiative of individual ministries or on the initiative of the European Secretariat. Countries which have a working group structure based on the initiative of ministries are likely to have a less permanent system, since there is no real central oversight. Poland, for instance, operates a flexible system of working groups, which are created by ministers on an ad hoc basis. In most countries, however, the European secretariat plays a role in the process of creating working groups and sends a representative to each working group meeting. The question can be raised as to which of these systems is likely to function more effectively. There are good arguments for working groups to be established and co-ordinated by the European secretariat. This will create a more uniform structure and make it more likely that government policy is reflected in the deliberations of the working groups. A decentralised system has the advantage that the ministry which creates or co-ordinates a working group will view the working group as part of its own structure. This will make it more likely that working group decisions and recommendations are actually implemented.

59. The working group structures set up in central and eastern European countries have not always been permanent. In several countries, a revision of the structures has either taken place recently or has been planned for the near future. It is also difficult to estimate the real importance of the working groups since no information is available on how frequently they meet and the extent to which their recommendations and decisions are followed by the ministries. The impression obtained from the answers 
to the questionnaire is that the working groups are the weakest link in the policy-making structure, which is not surprising in view of the general co-ordination problems in the administrations of central and eastern European countries, as highlighted in the majority of the Commission avis.

\section{Preparation for Accession}

60. Central and eastern European countries have made considerable progress with the development of general structures for the management of policy-making in EU affairs. These structures are not yet sufficiently stable and often suffer from the lack of co-ordination and policy-making capacities. However, it is likely that structures for the management of EU affairs will stabilise during the membership negotiation period. Structural problems can be expected to get resolved in the coming years as part of the general effort to improve administrative structures. The explicit references to the need to improve administrative capacities in the Commission avis of practically all central and eastern European countries will most likely help to keep up the momentum of administrative reform.

61. Unlike the considerable progress made on the development of institutions and structures for the management of policy-making in EU affairs, the development of structures and strategies for membership negotiations is still in its initial stages in most candidate Member countries. This section contains an overview of the structures in place for the negotiation process, the state of affairs regarding the formulation of a national negotiation strategy, and the strategy for communications with society on EU membership issues.

62. As far as institutional structures for negotiations are concerned, most countries intend to use the existing policy-making structures for the preparation of national positions and the selection of negotiators. A special structure charged with the oversight of the negotiation process exists in Lithuania (the Delegation on Preparation for EU Membership Negotiations) and will be created in the near future in Latvia. The Secretariat to the Delegation on Preparation for EU Membership Negotiations in Lithuania is placed in the Ministry of Foreign Affairs. In Latvia, the Secretariat to the negotiation team will be also under the Ministry of Foreign Affairs. In the Czech Republic, the working group structure will be adapted to enable it to function as specialised groups to assist the negotiating team with the preparation of the Czech position during the accession negotiations. In Slovakia, special structures have been set up inside ministries and between ministries to support the work of the negotiation teams. In other countries, the creation of special procedures for the preparation of national positions for the accession negotiations is not planned for the time being.

63. Not all countries have as yet made a decision on what institution will lead the negotiations. For the countries which have made a decision, the negotiations will be led by the minister of foreign affairs or by a different representative of that ministry. This is true even for those countries where the role of the ministry of foreign affairs in the policy-making process is limited. In Slovakia, the negotiating teams have also been created.

64. The preparation of a national strategy for the negotiation process is at a different stage of development in each country. All countries intend to develop a national strategy which should serve as the framework for the approach in the negotiation process. A national strategy document has been finalised in Poland and almost finalised in Estonia. In all other countries, it is in different phases of preparation.

65. The development of training structures to create a core group of experts in European affairs in the administration is generally at an advanced stage. An overall training strategy has been developed by several countries (Czech Republic, Estonia, Hungary, Latvia, Poland, Slovenia,) which should lead to a 
gradual increase in the number of experts in EU affairs in the administration. Training programmes for future negotiators are at an early stage of development.

66. The main problem regarding the impact of training is the high level of turnover among civil servants. Changes in personnel following elections and the competition from the private sector, which has an increasing interest in EU specialists, make it difficult to estimate the real effect of training programmes, in particular in countries which do not have a civil service law. The long term availability of specialists in EU affairs is therefore in serious doubt. Only the improvement of employment conditions in the administration could lead to an improvement in this situation.

67. A last issue to be discussed under this heading is the interaction between government and society over the accession process. It is important that there is an open debate on the costs and benefits of EU membership in the countries. Support for EU membership is still generally high in Central and Eastern Europe; Eurobarometer results indicate that a large majority of the citizens of central and eastern European countries would vote 'yes' in a referendum on EU membership. The results also show an awareness of the potential cost of membership, in particular for the agricultural sector, but this seems to have little influence on the general positive perception of possible EU membership. At the same time it is clear that more education and information on EU affairs has to be provided in order to help citizens to build up an informed opinion on EU affairs. Governments have a very important role to play in this area, since there are few other institutions which could play a role in the provision of information on EU affairs. Central and eastern European governments appear to be well aware of the need to provide more information to stimulate a more informed debate on the consequences of EU membership. All countries plan to complete a national communication strategy in the near future. However, the number of countries which has already developed a public information and communication strategy remains rather small. The communication strategies vary from general provision of information to the public to the development of comprehensive packages of actions targeted at different sectors of society.

68. Preparations for membership negotiations have been started in all candidate Member States. The process of the selection and training of negotiators is in its initial stages, and all countries have made some progress in the development of negotiation strategies. The training of civil servants in EU affairs has also started, but training programmes can only have a long-term effect once the level of turnover among civil servants, especially those with a knowledge of foreign languages and EU affairs, is reduced. Information and communication strategies are being developed in most candidate Member States and should help to build up an informed public opinion on EU membership. Due to the lack of detail on the contents of these information programmes, it is difficult to draw conclusions on their quality and potential impact.

\section{The Approximation of Legislation}

69. The approximation of legislation is a crucial element of the membership preparation process for central and eastern European countries. For three reasons the approximation process is more complicated in the candidate Member States from Central and Eastern Europe than in the countries which joined the EU in the previous two waves of enlargement. The first reason is the ever increasing volume and complexity of the acquis communautaire. The second is the simultaneity of the transition of the legal system in Central and Eastern Europe and the approximation process. While in some ways the need to create the legislative framework for a market economy makes it easier to approximate legislation (since the two can take place at the same time), the workload generated by the simultaneity of the two processes puts too much pressure on the new institutional systems of the countries. A third problem is the relatively limited expertise in European law in Central and Eastern Europe, which can hamper the process of approximation. 
70. The development of a well-functioning system to ensure compliance of new legislation with EU standards, and the adoption of a clear and realistic programme for approximation of existing legislation, can address the three problems raised above, especially if accompanied by a well-developed training and education programme for judges, lawyers and parliamentary experts (civil service training has been dealt with in the previous section).

71. Structures to ensure the compliance of new legislation with EU standards have been put in place in all central and eastern European countries. A number of different methods to ensure compliance of legislation drafted in the administration have been developed:

- Compliance check by the legislative council (Bulgaria and Romania);

- Decentralised system, each ministry is responsible for checking the compatibility of legislation (Estonia, Hungary). In the Czech Republic and Hungary, the Ministry of Justice has a co-ordinating function;

- Compliance check by the European secretariat (Latvia, Poland);

- Compliance check by the Legal Bureau of the Ministry of European Affairs (Lithuania); and

- Compliance check by the Office of Legislation under the Prime Minister's Office (Slovenia).

72. A decentralised system of carrying out compliance checks obviously requires a much higher level of expertise in EU affairs at the individual ministries than a centralised system of compliance control. However, if the human resources are available to develop an effective system of compliance control in the ministries, this could obviously have a positive effect on the overall efficiency of the legislative process; there would be fewer cases of legislation sent back to the ministries for revision. The possible drawback of a decentralised system is that it can make it more difficult for the institution responsible for the co-ordination of the overall approximation process to keep track of progress in the implementation of the approximation strategy. The combination of decentralised ensurance of compliance and a co-ordinator function for one institution, as exists in the Czech Republic and Hungary, might combine the advantages of both systems.

73. The compliance check on draft legislation mainly exists to avoid that new laws proposed to be adopted by parliament are in conflict with European law. In addition to compliance checks on all new legislation, all candidate Member States have developed national programmes or strategies for the harmonisation of legislation. The co-ordination of the implementation of these national programmes is either carried out by the European secretariat, by the ministry responsible for the approximation of laws (e.g. Ministry of Justice and Approximation of Laws in Bulgaria; Ministry for European Affairs in Lithuania; Ministry of Justice in the Czech Republic).

74. Some states have decided to differentiate between the institutional responsibility for compliance control, which is essentially a technical function, and the responsibility for the development and implementation of the national approximation strategy, which is by nature a more political task. Such a separation might make sense in terms of separating technical and political work. It is important to stress the need to develop a realistic approach to approximation, where possible based on impact analysis. Approximation strategies should reflect the institutional capacities and the economic realities of a given country, not an imposed external timetable. In the long term, countries will benefit from having a realistic approach to approximation, rather than opting for political opportunism. A system to monitor progress and to periodically revise harmonisation strategies has been set up in most countries. 
75. The main method of approximation is to amend existing national legislation or to draft new national legislation to ensure compliance between national legislation and EU norms. The transfer of European text into national legislation is used by some countries, but remains the exception to the rule even in these countries.

76. There are different types of government interaction with parliament over the approximation process. In Bulgaria, for instance, there are as yet no formal channels of interaction between government and parliament over the approximation process. The clear majority enjoyed by the current government acts as a guarantee that governmental priorities, in particular the harmonisation strategy, are reflected in the legislative programme of parliament. In Latvia, this is treated as a normal aspect of relations between government and parliament. In other countries, formal links between either the European Affairs Committee and/or the Legislative Committee and the government committee/commission for European integration have been established. These formal links consist either of regular meetings between representatives of the different committees and/or of participation of representatives from parliamentary committee(s) in the sessions of the government committee responsible for EU affairs (Lithuania, Poland, Romania). This participation can be statutory (Poland) or on a case-by-case basis. In the Czech Republic, formal and informal meetings on approximation are held between representatives of government and parliament on an ad hoc basis.

77. The way the approximation process is handled in the ten candidate Member States differs from country to country. Patterns of inter-institutional relations can be distinguished, for instance, in the way compliance checks are carried out and also in the interaction between government and parliament. However, the level of diversity is much higher in this issue than in other aspects of the development of structures for the management on EU affairs.

78. A final point to be raised regarding the relations between government and parliament, even though not dealt with explicitly in the questionnaire, is the involvement of parliament in the accession negotiation process. The legislative workload to be generated by the accession treaty will have significant implications for parliament. This is therefore an additional important issue to be reflected on.

\section{The Management of Financial Assistance}

79. The management of financial assistance is an important issue in the development of the relations between the EU and the candidate Member States. The development of financial control systems, in particular to monitor the use of financial assistance, has been highlighted as an important issue in the European Commission Opinion on the membership applications of the central and eastern European applicants. The SIGMA questionnaire does not deal in detail with issues of financial control, but poses questions on the relation between financial assistance and the process of European integration.

80. The responsibility for the management of financial assistance is divided in some countries and concentrated in one institution in others. Bulgaria has the most decentralised system of management of financial assistance; each ministry deals with assistance in its own area. The Bulgarian Department for European Integration of the Ministry of Foreign Affairs has to guarantee coherence in the use of assistance to the European integration process, but the department has the function of co-ordinator rather than manager of assistance in this area. In Estonia, the responsibility for the management of assistance is shared between the Ministry of Finance (general assistance) and the Office for European Integration (assistance related to the European integration process). In the Czech Republic, the political responsibility is with the Ministry of Foreign Affairs, but in practise it is the Centre for Foreign Assistance in the Ministry of Finance which deals with the management of assistance. Questions relating to financial 
assistance to the European integration process are discussed in the Czech Working Committee for the Implementation of the European Agreement, the committee of senior officials for EU affairs. In Hungary, Poland, Romania and Slovakia, the management of assistance is assigned to one institution, and in all cases, the same institution hosts or serves as the European integration secretariat. In Latvia and Lithuania, foreign assistance is managed by an inter-ministerial co-ordination council chaired by the Ministry of Finance and Foreign Affairs respectively.

81. All countries clearly attach special importance to financial assistance in the area of European integration. All have put in place special arrangements to ensure that assistance is used to achieve the objective of EU membership. This is particularly clear in countries which have given the responsibility for the management of financial assistance to the European secretariat.

\section{Self-Analysis of the System for the Management of EU Affairs}

82. In the SIGMA questionnaire, the candidate Member States from Central and Eastern Europe were asked to identify the main strengths and weaknesses of their own policy-making systems in EU affairs. The main point of strength identified by most countries was the progress made in the creation of the institutions for the management of EU affairs. It appears that the creation of central decision-making institutions has been one of the primary concerns of policy-makers in Central and Eastern Europe. Few other points of strength were identified in the self-analysis. One response referred to the possibility of transforming the pre-accession policy-making system into a policy-making system under membership; others made special mention of the creation of specialised EU affairs units in the individual ministries, while one country identified the well-functioning horizontal co-ordination system as a main point of strength. It should be noted that the same country included the insufficient formalisation (i.e. insufficent legal acts) of this policy co-ordination system in its analysis of the weaknesses of its decision-making system.

83. Whereas there is a high degree of similarity regarding the positive elements of the new institutional structure, there is much more diversity in the weaknesses identified in the self-analysis. There was no response from Hungary and Bulgaria on this point (in the case of Bulgaria because the new institutional system had been in place for a very short period only). The weaknesses identified in the responses included the partial completion of institutional systems and strategy documents (for instance training and information strategies); unsatisfactory law drafting and policy implementation records; the lack of qualified staff and suitable equipment; problems with the adaptation of individual ministries; and weakness of co-ordination and communication between institutions.

84. The weaknesses identified in the self-analysis show a great deal of similarity with the conclusions drawn by the European Commission in its Opinions on the membership bids of the countries of Central and Eastern Europe. A positive evaluation was made of the institutional systems developed for the management of EU affairs, even though the Commission also stressed the need to consolidate and strengthen the newly created institutional systems. However, questions were raised about the policy co-ordination capacities (in most countries) and the availability of human resources to manage policy processes in EU affairs. Concerns over policy implementation capacities formed an underlying motive for the emphasis on the creation and improvement of these institutions in the Cannes White Paper. The evaluation of the institutions responsible for policy implementation, as published in the Commission avis, was highly critical. A combination of the self-analysis carried out by the candidate Member States and the European Commission Opinion would indicate that strengthening the institutional system for the management of EU affairs (mostly as far as human resources are concerned and in particular in line 
ministries), improving co-ordination capacities, and strengthening institutions responsible for policy implementation are priority issues for the coming years.

\section{Administrative Reform and European Integration}

85. The administrative capacity to take on the obligations of membership has become an important criterion for EU membership. The Commission Opinion on the EU membership applications of the central and eastern European candidate Member States confirms the trend towards the increasing importance of administrative capacities as an aspect of EU membership.

86. Politicians in Central and Eastern Europe have been quick to realise the growing importance of a well-functioning administration as a condition for EU membership. Administrative reform used to be a relatively neglected area of reform in many countries. Following the publication of the Cannes White Paper, administrative reform was generally given a higher level of priority. However, the critical evaluation of administrative capacities in the European Commission avis, even though more strong in some countries than in others, indicates that a lot of work remains to be done to bring administrative capacities up to level required for countries to fully participate in the EU policy process.

87. Even though there is a relation between administrative reform and European integration, the institutional links between institutions involved in the management of administrative reform and the management of European affairs are not always obvious. There are several reasons for this. First, the responsibility for administrative reform is not always clearly assigned. In Bulgaria, administrative reform is shared between two ministers, but there is no administrative reform unit as such. In Estonia, responsibility rests with the individual ministries, even though co-ordination tasks have been assigned to several ministries. In Lithuania, the Ministry for Public Administration and municipalities is responsible for administrative reform. In Hungary, Latvia, Poland and Romania, responsibility rests in the centre of government. In Hungary, Latvia and Poland, a specific unit has been created to manage the administrative reform process, while in Romania central government reform is, for the time being, managed by a steering committee, consisting of representatives of various government departments.

88. Second, in cases where responsibility has been assigned, the responsibilities for administrative reform and European affairs are often placed in institutions which have limited connections. In most countries, the minister or official responsible for administrative reform is not a member of the government committee for EU affairs, which automatically limits the scope for exchange of information between the two areas. If both areas are managed by sub-units of the central institution of government, this might increase the scope for co-operation, but this is not the case in all countries. In Lithuania, for instance, administrative reform is managed by a separate ministry, while the responsibility for EU affairs rests with two other ministries. One country where an institutional link has already been created between the government committee for European integration and the minister responsible for administrative reform is Bulgaria, where the Secretary-General of the Council of Ministers, who is at the moment (February 1998) also the Minister for Public Administration, is represented in the Inter-ministerial Committee and in the Council for European Integration. In Latvia, permanent co-ordination mechanisms between the institutions responsible for EU affairs and administrative reform are being developed. In Poland, the Head of the Department for Public Administration Reform is an ex-officio member of the Council for European Integration, an advisory body to the Prime Minister. However, there was no linkage between the two institutions in the decision-making process. It seems that even though central and eastern European countries have recognised the importance of having a well-functioning administrative system, administrative reform is not high enough on the political agenda for the representatives of the 
administrative reform unit to be included in the core decision-making units of the EU policy-making process.

89. The self-analyses of the main problems in public administration and their impact on the European integration process reflect the general awareness among central and eastern European politicians of the relationship between the two issues. The main problems identified were the general weakness in institutional and administrative structures (Bulgaria, Latvia, Romania) and the lack of qualified and adequately trained personnel (Hungary and Lithuania). Among the countries which answered this set of questions, only Estonia did not identify serious problems in the public administration. The main reasons given as to why it is difficult to address problems in the administration are the lack of financial means and the lack of qualified personnel. Two of the Baltic states also mentioned the problems arising from the need to develop a new institutional system.

90. General administrative reform strategies are in the process of development in Bulgaria and Romania (where first priority has been accorded to local government reform), and in the process of implementation in Latvia. In Lithuania, a reform strategy was adopted but its implementation has not yet started. In Hungary, the first stage of the administrative reform process has been completed. The next phase of the administrative reform process is fully geared towards the specific requirements for European integration. Among the countries which answered this section of the questionnaire, Hungary is the only country which reported a specific accession oriented administrative reform strategy.

91. As described above, the link between European integration and administrative reform is not as obvious as it might seem. Administrative capacities are obviously not the main criterion on which the membership applications for the countries of Central and Eastern Europe have been judged. However, even if membership is not conditional on the quality of the administration, a high-quality administration is required to meet the other conditions set out in the avis. It is therefore important that the relationship between European integration and administrative reform is not only acknowledged but also operationalised in practical terms.

\section{Conclusions}

92. The central and east European candidate Member States report considerable progress in the development of institutions and structures for the management of EU affairs. The legislative basis for the institutional framework has been created in all candidate Member States and, with few exceptions, all the institutions provided for in legislation have been created. The same is true for the creation of European integration units in the ministries. The creation of inter-ministerial working groups appears to be a more problematic issue. Whereas the central decision-making structures for EU affairs are relatively permanent, frequent changes have been made in working groups structures. The answers to the questionnaire give the impression that working group structures are generally the weakest link in the institutional system. This is an issue to be considered. Working groups do not only have a role in the formulation of policy on substantive questions related to European integration but can also exercise a co-ordination function at the level of senior officials.

93. The preparation for the management of the accession process has been started in all candidate Member States that responded to the questionnaire. Interestingly, the Ministry of Foreign Affairs appears to have obtained a central role in the negotiation process in the majority of the countries, which seems in contrast to the more limited role Ministries of Foreign Affairs appear to play in the management of EU policy-making. As the process of negotiation requires continuous adjustment in policy positions, as well 
as a flow of information from ministries, the question of the relation between the European integration co-ordination structure and the negotiation structure is quite important.

94. Structures for the management of the approximation of laws are well established. Procedures to ensure compliance of new legislation with EU standards have been put in place, and national strategies for the systematic revision and adaptation of legislation are in the process of implementation. The procedures put in place, however, mostly deal the process in the administration. Relations between the administration and parliament in the approximation process are not always well developed, which can pose problems, in particular when a government is a coalition government and/or does not command a clear majority in parliament. The development of a compliance control system for the institutional system as a whole might be an option to consider.

95. The management of financial assistance is increasingly geared towards assisting the preparation for membership. The European Commission Phare Programme, which remains the main financial assistance programme for the candidate Member States, has been re-oriented to increasingly support the accession process. The management of financial assistance is generally either well co-ordinated with or part of the functions of the European secretariat.

96. The self-analysis of the institutional system and procedures for the management of EU affairs, carried out by most of the countries which responded to the questionnaire, reveals rather obvious weaknesses in the policy-making systems. The weakness of co-ordination capacities is a general problem for most central and eastern European administrations. The same is true for policy implementation, where central and eastern European countries have had to create an almost completely new institutional network for policy implementation. The process to create this institutional network has not yet been completed in most of the candidate Member States. This affects policy implementation in EU affairs just as much as policy implementation in any other area. The concerns over implementation capacities expressed by the European Commission in its avis are in line with this self-analysis, but should be seen in the right context. Apart from the development of policy co-ordination capacities and the construction of policy implementation networks, the lack of qualified personnel is the other main weakness of the policy-making systems for EU affairs in the countries mentioned in the self-analyses.

97. The last category of the SIGMA questionnaire was the link between administrative reform and European integration. Apart from the problems in the administrative systems discussed in the previous section, the lack of clear institutional connections between administrative reform units and the structures responsible for the management of EU affairs is one of the main potential sources of problems.

98. Considerable progress made in the development of systems for the management of EU affairs in Central and Eastern Europe. If the institutional systems work as well as the answers to the questionnaire suggest, the existing systems will probably manage to cope with the workload generated by the accession process, if measures are taken to improve the main deficiencies highlighted above. Whether these structures will be sufficient to manage EU affairs once countries join the Union is a completely different matter. Substantial improvements will have to be made in policy implementation capacities in general, as well as in the development of accountability mechanisms, in addition to the improvement of structures for policy development. A better integration of administrative reform policy and EU accession policy will be required to ensure that countries are administratively prepared to join the EU when membership becomes a reality. 


\section{ANNEX 1: CLASSIFICATION OF QUESTIONNAIRE RESPONSES}

\section{Central Decision-Making Structures}

\begin{tabular}{|c|c|c|c|c|}
\hline $\begin{array}{c}\text { Institutional } \\
\text { Structures: Country }\end{array}$ & $\begin{array}{l}\text { Ministerial Committee(s)/ } \\
\text { Council of Ministers }\end{array}$ & Designated Minister & $\begin{array}{l}\text { Committee of } \\
\text { Senior Officials }\end{array}$ & Secretariat \\
\hline Bulgaria & $\begin{array}{l}\text { 1. Special sessions on EI of the CoM to } \\
\text { define national policy, approve mandates } \\
\text { and documents, appoint negotiators; } \\
\text { 2. Meets at least once a month, decides by } \\
\text { consensus. }\end{array}$ & $\begin{array}{l}\text { Prime Minister chairs special } \\
\text { sessions; } \\
\text { Minister of Foreign Affairs } \\
\text { chairs the Council for } \\
\text { European Integration, main } \\
\text { co-ordinator; } \\
\text { Ministry of Justice co-ordinates } \\
\text { activities re: approximation of } \\
\text { laws. }\end{array}$ & $\begin{array}{l}\text { 1. Council for EI (Deputy } \\
\text { Ministers of relevant } \\
\text { departments), prepares special } \\
\text { sessions, monitors policy } \\
\text { implementation, creates working } \\
\text { groups; } \\
\text { 2. Interministerial Committee on } \\
\text { EI (Heads of EI units). }\end{array}$ & $\begin{array}{l}\text { European Integration Department at the } \\
\text { Ministry of Foreign Affairs; } \\
\text { Main tasks: co-ordination, review, } \\
\text { preparation of negotiations, training, } \\
\text { monitoring approx. of laws. }\end{array}$ \\
\hline Czech Republic & $\begin{array}{l}\text { Government Committee for EI, limited } \\
\text { statutory membership, other ministries and } \\
\text { institutions can be invited, meets once } \\
\text { every two months; } \\
\text { The Committee has a preparatory function, } \\
\text { decisions can be taken only by the } \\
\text { government. }\end{array}$ & $\begin{array}{l}\text { Ministry of Foreign Affairs } \\
\text { responsible for overall } \\
\text { co-ordination. }\end{array}$ & $\begin{array}{l}\text { Working Committee for the } \\
\text { Implementation of the Europe } \\
\text { Agreement, headed by the } \\
\text { Deputy Ministry of Foreign } \\
\text { Affairs; } \\
\text { Meets at least once per month, } \\
\text { sets up working groups. }\end{array}$ & $\begin{array}{l}\text { Two Departments in the Ministry of } \\
\text { Foreign Affairs, one for co-ordination of } \\
\text { relations with the EU, one for political } \\
\text { relations with the EU. }\end{array}$ \\
\hline Estonia & $\begin{array}{l}\text { Ministerial Committee on European } \\
\text { Affairs, chaired by the PM, limited number } \\
\text { of ministries; } \\
\text { Meets at least once per month; } \\
\text { Decides by consensus. }\end{array}$ & $\begin{array}{l}\text { Prime Minister is responsible } \\
\text { for European Integration. }\end{array}$ & $\begin{array}{l}\text { Council of Senior Civil Servants, } \\
\text { chaired by head of the Office on } \\
\text { EI; } \\
\text { Meets fortnightly; } \\
\text { Decides by Consensus; } \\
\text { Special role for Ministries of } \\
\text { Foreign Affairs and Justice. }\end{array}$ & $\begin{array}{l}\text { Office of EI in the State Chancellery; } \\
\text { Main tasks: co-ordination, monitoring } \\
\text { and strategic planning. }\end{array}$ \\
\hline Hungary & $\begin{array}{l}\text { Cabinet for EI, Chaired by the Prime } \\
\text { Minister, limited number of ministries, } \\
\text { cannot take legally binding decisions; } \\
\text { Decides by voting; } \\
\text { Meets at least once per month. }\end{array}$ & Minister of Foreign Affairs. & $\begin{array}{l}\text { Interministerial Committee for } \\
\text { EI, State Secretaries and deputy } \\
\text { State Secretaries. }\end{array}$ & $\begin{array}{l}\text { State Secretariat for EI at the Ministry of } \\
\text { Foreign Affairs; } \\
\text { Strategic Task Force for Integration at } \\
\text { the PMO. }\end{array}$ \\
\hline
\end{tabular}




\begin{tabular}{|c|c|c|c|c|}
\hline Latvia & $\begin{array}{l}\text { EI Council, chaired by the PM or by the } \\
\text { minister of EU affairs (if PM is absent), } \\
\text { limited number of ministries; } \\
\text { Meets at least once per month; } \\
\text { Decides by consensus. }\end{array}$ & $\begin{array}{l}\text { Minister for EU affairs, reports } \\
\text { to the PM. }\end{array}$ & $\begin{array}{l}\text { Council of Senior Civil servants } \\
\text { on EI; } \\
\text { Special role for Ministry of } \\
\text { Foreign Affairs. }\end{array}$ & $\begin{array}{l}\text { European Integration Bureau (EIB), } \\
\text { under the Minister for EU affairs: } \\
\text { monitoring, co-ordination, information, } \\
\text { planning. Broad mandate. }\end{array}$ \\
\hline Lithuania & $\begin{array}{l}\text { Governmental EI Commission, chaired by } \\
\text { the Prime Minister, limited number of } \\
\text { ministries represented, convened by the } \\
\text { Head of the Delegation on Preparation for } \\
\text { EU Membership Negotiations; } \\
\text { Meets when required; } \\
\text { Decisions by qualified majority. }\end{array}$ & $\begin{array}{l}\text { Responsibility shared: Minister } \\
\text { of Foreign Affairs (overall } \\
\text { co-ordination) and Minister for } \\
\text { European Affairs (preparation } \\
\text { and co-ordination of national } \\
\text { programme for approx. of laws } \\
\text { and preparation of the } \\
\text { programme for economic } \\
\text { integration). }\end{array}$ & $\begin{array}{l}\text { Delegation on Preparation for EU } \\
\text { Membership Negotiation, } \\
\text { convenes meeting of the } \\
\text { Governmental Commission, } \\
\text { settles disputes and co-ordinates } \\
\text { accession policies. }\end{array}$ & $\begin{array}{l}\text { European Integration Department at the } \\
\text { Ministry of Foreign Affairs, acts as the } \\
\text { secretariat of the Governmental EI } \\
\text { Commission and the Delegation on } \\
\text { Preparation for EU Membership } \\
\text { Negotiation. }\end{array}$ \\
\hline Poland & $\begin{array}{l}\text { Committee for EI, chaired and convened } \\
\text { by the Prime Minister, limited number of } \\
\text { ministries represented, includes } \\
\text { non-ministerial representatives; } \\
\text { Meets on average once per month; } \\
\text { Decides by majority voting. }\end{array}$ & $\begin{array}{l}\text { Secretary of State (Secretary of } \\
\text { the Committee on EI), reports } \\
\text { to the PM. }\end{array}$ & $\begin{array}{l}\text { Meeting of under-secretaries of } \\
\text { State of ministries involved in } \\
\text { the Committee for EI, decides by } \\
\text { consensus, meets before each } \\
\text { meeting of the Committee. }\end{array}$ & $\begin{array}{l}\text { Office of the Committee for European } \\
\text { Integration, independent office within } \\
\text { the Polish central administration, has a } \\
\text { wide range of responsibilities. }\end{array}$ \\
\hline Romania & $\begin{array}{l}\text { Inter-Ministerial Committee for EI, chaired } \\
\text { by the Prime Minister, participation in } \\
\text { meetings varies, includes ministers but can } \\
\text { also include representatives from other } \\
\text { institutions; } \\
\text { Usually convened by the Minister for EI; } \\
\text { Generally meets quarterly, decisions made } \\
\text { by consensus. }\end{array}$ & $\begin{array}{l}\text { Minister for European } \\
\text { Integration (executive president } \\
\text { of the Inter-Ministerial } \\
\text { Committee), reports to the } \\
\text { Prime Minister; } \\
\text { Special role for the Minister of } \\
\text { Foreign Affairs (political } \\
\text { co-operation) and the Minister } \\
\text { of Trade (trade provisions of } \\
\text { the association agreement). }\end{array}$ & $\begin{array}{l}\text { Department for EI at the } \\
\text { Romanian Government convenes } \\
\text { meetings of representatives of } \\
\text { ministries/state institutions } \\
\text { whenever required. No } \\
\text { permanent committee of officials. }\end{array}$ & $\begin{array}{l}\text { Department for EI at the Romanian } \\
\text { government, subordinated to the Minister } \\
\text { for EI, prepares strategies, acts as a } \\
\text { clearing house in approx. of laws, } \\
\text { approves proposed actions of other state } \\
\text { institutions in EU related matters. }\end{array}$ \\
\hline Slovakia & $\begin{array}{l}\text { Council of the Slovak Government for the } \\
\text { Integration of the Slovak Republic in the } \\
\text { EU, advisory body, limited membership, } \\
\text { meets once per month. }\end{array}$ & $\begin{array}{l}\text { Deputy Prime Minister with } \\
\text { own support structure. }\end{array}$ & $\begin{array}{l}\text { No permanent committee } \\
\text { reported. }\end{array}$ & $\begin{array}{l}\text { Main co-ordinating office in the } \\
\text { Government Office, Department of EI, } \\
\text { Department of EI in the Ministry of } \\
\text { Foreign Affairs deals with Europe } \\
\text { Agreement structures. }\end{array}$ \\
\hline Slovenia & Under revision. & $\begin{array}{l}\text { New Minister for European } \\
\text { Affairs appointed, division of } \\
\text { tasks under revision. }\end{array}$ & Under revision. & $\begin{array}{l}\text { European Secretariat attached to the } \\
\text { Prime Minister's Office, structure and } \\
\text { competencies to be defined. }\end{array}$ \\
\hline
\end{tabular}




\section{Internal Organisation of Ministries, Cross-Sectional Working Groups and External Representation}

CCET/SIGMA/PUMA(98)2

\begin{tabular}{|c|c|c|c|}
\hline $\begin{array}{l}\text { Institutional Structures } \\
\text { and Arrangements: } \\
\text { Country }\end{array}$ & EU Affairs Within Ministries & Sectoral Working Groups & Representation to the EU \\
\hline Bulgaria & $\begin{array}{l}\text { Most ministries have specialised units and } \\
\text { experts in each or most departments. }\end{array}$ & $\begin{array}{l}26 \text { working groups exist, following the structure of } \\
\text { the Commission questionnaire. }\end{array}$ & $\begin{array}{l}\text { Under the Ministry of Foreign Affairs; } \\
\text { Ministry of Trade and Tourism represented. }\end{array}$ \\
\hline Czech Republic & $\begin{array}{l}\text { Ministries have special European integration } \\
\text { units. }\end{array}$ & $\begin{array}{l}22 \text { working groups exist, Ministry of Foreign } \\
\text { Affairs is represented in all groups, they are } \\
\text { chaired by the ministry most closely involved in } \\
\text { the subject matter. Working group structure might } \\
\text { be revised. }\end{array}$ & $\begin{array}{l}\text { Permanent mission under the Ministry of Foreign } \\
\text { Affairs, other ministries and institutions can be } \\
\text { represented. }\end{array}$ \\
\hline Estonia & $\begin{array}{l}\text { Decentralised system; varies from ministry to } \\
\text { ministry. }\end{array}$ & $\begin{array}{l}\text { Policy oriented and technical working groups } \\
\text { exist; } \\
\text { Co-ordinated by designated ministries; } \\
\text { Ministries deliver results to central co-ordinating } \\
\text { body. }\end{array}$ & $\begin{array}{l}\text { Under the Ministry of Foreign Affairs; } \\
\text { Ministries of Agriculture, Justice and Finance } \\
\text { represented; } \\
\text { Presents Estonian positions to the EU. }\end{array}$ \\
\hline Hungary & Special units exist. & $\begin{array}{l}27 \text { groups following the structure of the } \\
\text { questionnaire plus } 4 \text { additional groups, state } \\
\text { secretariat represented in each group. }\end{array}$ & $\begin{array}{l}\text { Under the Ministry of Foreign Affairs; } \\
\text { Ministries of Industry and trade and Tourism } \\
\text { represented at the moment. }\end{array}$ \\
\hline Latvia & $\begin{array}{l}\text { Varies between ministries; obligation to } \\
\text { appoint an official responsible for EU affairs. }\end{array}$ & $\begin{array}{l}23 \text { working groups under the EIB, main function } \\
\text { relates to approximation of laws. System under } \\
\text { revision. }\end{array}$ & $\begin{array}{l}\text { Under the Ministry of Foreign Affairs, Ministry of } \\
\text { Agriculture represented, in future also the Ministry of } \\
\text { Education and Science. }\end{array}$ \\
\hline Lithuania & Each ministry has a separate unit on EI. & $\begin{array}{l}10 \text { working groups, dealing with approximation of } \\
\text { legislation and institutional structures required for } \\
\text { implementation. }\end{array}$ & $\begin{array}{l}\text { Under the Ministry of Foreign Affairs, no special } \\
\text { attachés yet, but planned for the future. }\end{array}$ \\
\hline Poland & Each ministry has a special unit for EI. & $\begin{array}{l}\text { Sectoral working groups function on an } a d \text { hoc } \\
\text { basis, not related to the white paper structure. }\end{array}$ & $\begin{array}{l}\text { Under the Ministry of Foreign Affairs, co-ordinated } \\
\text { multilateral relations. }\end{array}$ \\
\hline Romania & $\begin{array}{l}\text { Each ministry has a special unit on EI, units } \\
\text { have also been set up in the prefectures. }\end{array}$ & $\begin{array}{l}\text { There are } 32 \text { working groups, } 23 \text { related to White } \\
\text { Paper and } 9 \text { related to the institutional structures } \\
\text { set up under the Europe Agreement. }\end{array}$ & Under the Ministry of Foreign Affairs, EU directorate. \\
\hline Slovakia & Special departments in each ministry. & $\begin{array}{l}23 \text { working groups for the implementation of the } \\
\text { White Paper. }\end{array}$ & $\begin{array}{l}\text { Under the Ministry of Foreign Affairs, includes } \\
\text { representatives for the Ministries of Finance, the } \\
\text { Economy and Agriculture. }\end{array}$ \\
\hline Slovenia & Under revision. & Under revision. & Under revision. \\
\hline
\end{tabular}




\section{Managing the Accession Process}

\begin{tabular}{|c|c|c|c|c|}
\hline $\begin{array}{l}\text { Institutional } \\
\text { Arrangements and } \\
\text { Strategies: Country }\end{array}$ & $\begin{array}{l}\text { Institutional Arrangements } \\
\text { in Place for the Negotiation } \\
\text { Process }\end{array}$ & $\begin{array}{l}\text { Strategy and Priorities for } \\
\text { Accession }\end{array}$ & $\begin{array}{l}\text { Organisation of Training in } \\
\text { European Affairs }\end{array}$ & Communications with society \\
\hline Bulgaria & $\begin{array}{l}\text { New co-ordination structure } \\
\text { geared towards negotiations, } \\
\text { specific arrangement to be } \\
\text { formalised. }\end{array}$ & Draft strategy prepared. & $\begin{array}{l}\text { No general strategy, Ministries of } \\
\text { Foreign Affairs and Justice deal } \\
\text { with horizontal issues, specialist } \\
\text { training in the ministries. }\end{array}$ & $\begin{array}{l}\text { Special Phare project in place; } \\
\text { National communication strategy } \\
\text { to be developed; } \\
\text { Council for EI has a consultation } \\
\text { function. }\end{array}$ \\
\hline Czech Republic & $\begin{array}{l}\text { Decisions of the negotiation } \\
\text { team and its head are being } \\
\text { finalised. }\end{array}$ & Not answered. & $\begin{array}{l}\text { Overall concept on EI training in } \\
\text { place, special responsibility for the } \\
\text { Ministry of Foreign Affairs but } \\
\text { specialist training organised by the } \\
\text { ministries. }\end{array}$ & $\begin{array}{l}\text { Strategy for communications } \\
\text { defined and to be implemented } \\
\text { from early } 1998 \text {, some information } \\
\text { activities have been started already. }\end{array}$ \\
\hline Estonia & $\begin{array}{l}\text { To be dealt with by existing } \\
\text { structures; } \\
\text { Ministry of Foreign Affairs } \\
\text { will deliver chief negotiator. }\end{array}$ & $\begin{array}{l}\text { General objectives and strategy } \\
\text { defined, not yet specified and } \\
\text { prioritised. }\end{array}$ & $\begin{array}{l}\text { National training strategy for EI } \\
\text { exists, general training through EI } \\
\text { office, specific training through } \\
\text { ministries. }\end{array}$ & $\begin{array}{l}\text { Strategy of public awareness exists, } \\
\text { concrete action under preparation. }\end{array}$ \\
\hline Hungary & $\begin{array}{l}\text { No new structures envisaged, } \\
\text { chief negotiator from the } \\
\text { Ministry of Foreign Affairs. }\end{array}$ & $\begin{array}{l}\text { Strategy under preparation, } \\
\text { position paper on the acquis } \\
\text { under preparation. }\end{array}$ & $\begin{array}{l}\text { Training strategy adopted in June } \\
\text { 1997, different training } \\
\text { programmes for different aspects } \\
\text { of the EU policy process. }\end{array}$ & $\begin{array}{l}\text { Strategy for communications with } \\
\text { the public exists, in the process of } \\
\text { implementation. Developed with } \\
\text { Phare support. }\end{array}$ \\
\hline Latvia & $\begin{array}{l}\text { Special secretariat to be } \\
\text { established. Ministry of } \\
\text { Foreign Affairs will form the } \\
\text { negotiation team. }\end{array}$ & $\begin{array}{l}\text { Concept for Latvian } \\
\text { preparation for accession } \\
\text { negotiations has been drafted. }\end{array}$ & $\begin{array}{l}\text { Training strategy developed by the } \\
\text { EIB and the Latvian School of } \\
\text { Public Administration. }\end{array}$ & $\begin{array}{l}\text { Information strategy under } \\
\text { development. Gradual information } \\
\text { of the mass media. }\end{array}$ \\
\hline
\end{tabular}


CCNM/SIGMA/PUMA(98)39

\begin{tabular}{|c|c|c|c|c|}
\hline Lithuania & $\begin{array}{l}\text { Delegation on Preparation for } \\
\text { EU membership Negotiation, } \\
\text { Secretariat at Ministry for } \\
\text { European Affairs. }\end{array}$ & $\begin{array}{l}\text { Integration strategy and } \\
\text { position under preparation. }\end{array}$ & $\begin{array}{l}\text { Training for negotiators started, } \\
\text { overall training strategy under } \\
\text { preparation. }\end{array}$ & $\begin{array}{l}\text { National strategy for } \\
\text { Communication on EI under } \\
\text { preparation. }\end{array}$ \\
\hline Poland & $\begin{array}{l}\text { No decision on specific } \\
\text { structures or negotiating teams. }\end{array}$ & $\begin{array}{l}\text { National Strategy for } \\
\text { Integration. }\end{array}$ & $\begin{array}{l}\text { General EI training is part of the } \\
\text { National Strategy for Integration, } \\
\text { co-ordinated by the Office of the } \\
\text { Committee for EI. }\end{array}$ & $\begin{array}{l}\text { Part of the National Strategy for } \\
\text { Integration, comprehensive } \\
\text { package of actions directed at } \\
\text { different sectors of society. }\end{array}$ \\
\hline Romania & $\begin{array}{l}\text { No new arrangements } \\
\text { envisaged, chief negotiator will } \\
\text { be the Minister of EI. }\end{array}$ & $\begin{array}{l}\text { References in the general } \\
\text { government programme; } \\
\text { Department of EI is drafting a } \\
\text { detailed strategy based on the } \\
\text { National Strategy for Accession } \\
\text { to the EU. }\end{array}$ & $\begin{array}{l}\text { Decision process on the } \\
\text { composition of negotiating teams } \\
\text { started, strategy for training under } \\
\text { development. }\end{array}$ & $\begin{array}{l}\text { "Image Strategy" for the process of } \\
\text { Romanian accession to the EU has } \\
\text { been prepared, in the process of } \\
\text { being updated. }\end{array}$ \\
\hline Slovakia & $\begin{array}{l}\text { Chief negotiator and } \\
\text { negotiating teams appointed, } \\
\text { support structures in the } \\
\text { ministries and inter-ministerial } \\
\text { working groups. }\end{array}$ & Not answered. & Not answered. & Not answered. \\
\hline Slovenia & Not answered. & Not answered. & Not answered. & Not answered. \\
\hline
\end{tabular}




\begin{tabular}{|c|c|c|c|}
\hline $\begin{array}{l}\text { Institutional } \\
\text { Arrangements and } \\
\text { Strategies: Country }\end{array}$ & $\begin{array}{l}\text { Institutional Arrangements in Place for the } \\
\text { Approximation of Legislation }\end{array}$ & National Strategy for Approximation & Interaction with Parliament \\
\hline Bulgaria & $\begin{array}{l}\text { Organisational structure in place, compliance } \\
\text { check for all new legislation (legislative } \\
\text { council), training programme started. }\end{array}$ & $\begin{array}{l}\text { Strategy paper exists, sector-by-sector inventory } \\
\text { of the most suitable approach to approximation } \\
\text { was carried out. }\end{array}$ & $\begin{array}{l}\text { No formal procedure for co-ordination of legislative } \\
\text { activity of parliament with the executive. }\end{array}$ \\
\hline Czech Republic & $\begin{array}{l}\text { Ministry of Justice responsible, clause on } \\
\text { compatibility to be included in each legislative } \\
\text { proposal, information technology system for the } \\
\text { approximation of laws (ISAP) established. }\end{array}$ & $\begin{array}{l}\text { Timetable for transposition approved in July } \\
\text { 1997, based on National Strategy for } \\
\text { Approximation, progress reports written every } \\
\text { three months. }\end{array}$ & $\begin{array}{l}\text { Parliamentary institute connected to ISAP, formal } \\
\text { and informal meetings between parliament and } \\
\text { government on approximation organised on an ad } \\
\text { hoc basis. }\end{array}$ \\
\hline Estonia & $\begin{array}{l}\text { Organisational structure in place, compliance } \\
\text { check for all new legislation, training structures } \\
\text { in place (judges and civil servants). }\end{array}$ & $\begin{array}{l}\text { National strategy exists, main method is } \\
\text { modifying national legislation. }\end{array}$ & $\begin{array}{l}\text { Regular meetings with European Affairs Committee } \\
\text { and other relevant committees. }\end{array}$ \\
\hline Hungary & $\begin{array}{l}\text { Requirement that detailed justification on } \\
\text { compatibility is submitted with each draft law, } \\
\text { special training programmes in place. }\end{array}$ & $\begin{array}{l}\text { National programme exists, main method to } \\
\text { modify existing legislation, but decision is taken } \\
\text { on a case-by-case basis. }\end{array}$ & $\begin{array}{l}\text { Regular consultation between the Standing } \\
\text { Committee on European Affairs and government } \\
\text { officials. }\end{array}$ \\
\hline Latvia & $\begin{array}{l}\text { EIB checks compliance of all legislation } \\
\text { submitted to the Chancellery, training of judges } \\
\text { and lawyers in progress. }\end{array}$ & $\begin{array}{l}\text { National strategy exists, main method is } \\
\text { modifying national legislation. }\end{array}$ & $\begin{array}{l}\text { Part of the responsibilities of the Deputy PM } \\
\text { responsible for relations with parliament. }\end{array}$ \\
\hline Lithuania & $\begin{array}{l}\text { Legal Bureau under the Ministry for European } \\
\text { Affairs checks compliance, training institutions } \\
\text { for judges and lawyers set up. }\end{array}$ & $\begin{array}{l}\text { National Law Harmonisation programme exists, } \\
\text { main method is modifying national legislation. }\end{array}$ & $\begin{array}{l}\text { Members of parliament are invited for meeting of the } \\
\text { Government EI Commission to discuss } \\
\text { approximation issues. }\end{array}$ \\
\hline Poland & $\begin{array}{l}\text { Office of the Committee for EI checks } \\
\text { compliance, exception for legislative initiatives } \\
\text { of parliament or president (voluntary submission } \\
\text { only). }\end{array}$ & Part of the National Strategy for Integration. & $\begin{array}{l}\text { President of the Legislative Committee of parliament } \\
\text { sits in the government Committee for EI, opinion of } \\
\text { the Office of the Committee for EI submitted to } \\
\text { parliament. }\end{array}$ \\
\hline Romania & $\begin{array}{l}\text { Legislative council acts as a clearing house, } \\
\text { Department of EI co-ordinated the } \\
\text { harmonisation process, training programme } \\
\text { started. }\end{array}$ & $\begin{array}{l}\text { National Programme for Legislative } \\
\text { Harmonisation exists, both amending legislation } \\
\text { and drafting new legislation are used to ensure } \\
\text { compliance. }\end{array}$ & $\begin{array}{l}\text { Agreement between the Joint Parliamentary } \\
\text { Commission on EI, the Department of EI and the } \\
\text { Legislative Council forms the basis of co-operation. }\end{array}$ \\
\hline Slovakia & Not answered. & Not answered. & Not answered. \\
\hline Slovenia & Not answered. & Not answered. & Not answered. \\
\hline
\end{tabular}


5. Management of Assistance

\begin{tabular}{|c|c|c|}
\hline $\begin{array}{l}\text { Structures for the Management } \\
\text { of Assistance: Country }\end{array}$ & Location of Responsibility & $\begin{array}{l}\text { Relation with Structures and Policies } \\
\text { for European Integration }\end{array}$ \\
\hline Bulgaria & $\begin{array}{l}\text { Decentralised, each ministry deals with assistance in its own } \\
\text { area. }\end{array}$ & $\begin{array}{l}\text { Co-ordinator of EU affairs responsible for the coherence in } \\
\text { assistance in this area. }\end{array}$ \\
\hline Czech Republic & $\begin{array}{l}\text { Politically, the Ministry of Foreign Affairs; in practise, the } \\
\text { Ministry of Finance. }\end{array}$ & $\begin{array}{l}\text { Assistance and its relation to European integration discussed in } \\
\text { the Working Committee for the Implementation of the } \\
\text { European Agreement. }\end{array}$ \\
\hline Estonia & $\begin{array}{l}\text { Ministry of Finance (general); } \\
\text { Office for EI (EI related assistance). }\end{array}$ & $\begin{array}{l}\text { Technical Assistance Co-ordination Committee of the Council } \\
\text { of Senior Civil Servants defines needs and priorities. }\end{array}$ \\
\hline Hungary & Ministry of Foreign Affairs. & Both in the same ministry. \\
\hline Latvia & $\begin{array}{l}\text { Ministry of Finance (general); } \\
\text { Assisted by an inter-ministerial TA co-ordination group for } \\
\text { assistance in the area of EI. }\end{array}$ & Inter-ministerial TA co-ordination group acts as the linkage. \\
\hline Lithuania & $\begin{array}{l}\text { Minister of Foreign Affairs chairs the Aid Co-ordination } \\
\text { Council, responsibility divided between ministries of Foreign } \\
\text { Affairs, Finance, European Affairs and the Economy. }\end{array}$ & $\begin{array}{l}\text { European Integration Department of the Ministry of Foreign } \\
\text { Affairs forms the secretariat of the Aid Co-ordination Council, } \\
\text { Council formulates proposals for the use of assistance for EI } \\
\text { needs. }\end{array}$ \\
\hline Poland & $\begin{array}{l}\text { Office of the Committee for EI, special department for foreign } \\
\text { assistance. }\end{array}$ & Strict link between assistance and integration policy. \\
\hline Romania & $\begin{array}{l}\text { Directorate for Financial Co-operation and Economic } \\
\text { Assistance within the Department of European Integration. }\end{array}$ & $\begin{array}{l}\text { Both dealt with in the same institution, ensures that there is a } \\
\text { clear relation between assistance and European Integration. }\end{array}$ \\
\hline Slovakia & Department of Foreign Assistance at the Government Office. & $\begin{array}{l}\text { Department under the supervision of the Deputy Minister } \\
\text { responsible for European Integration. }\end{array}$ \\
\hline Slovenia & Not answered. & Not answered. \\
\hline
\end{tabular}


6. Strengths and Weaknesses of the System of Management of EU Affairs

\begin{tabular}{|c|c|c|}
\hline Strengths and Weaknesses: Country & Main Strengths & Main Weaknesses \\
\hline Bulgaria & $\begin{array}{l}\text { Mechanism covers all levels of the administration, can be } \\
\text { transformed into a policy formulation/implementation } \\
\text { procedure upon joining the EU, central role of the Ministry of } \\
\text { Foreign Affairs. }\end{array}$ & $\begin{array}{l}\text { System in place too short a time to enable analysis of } \\
\text { weaknesses. }\end{array}$ \\
\hline Czech Republic & Not answered. & $\begin{array}{l}\text { Reform of the Working Committee for the Implementation of } \\
\text { the Europe Agreement should eliminate current weaknesses in } \\
\text { the management of EU affairs, in particular in relation to policy } \\
\text { co-ordination. }\end{array}$ \\
\hline Estonia & $\begin{array}{l}\text { Well-functioning co-ordination structures, qualified personnel } \\
\text { and high level of awareness of complexity of tasks. }\end{array}$ & $\begin{array}{l}\text { Improvement of law drafting and problem identification } \\
\text { required, institution building not complete. }\end{array}$ \\
\hline Hungary & Not answered. & Not answered. \\
\hline Latvia & $\begin{array}{l}\text { Most institutions created, horizontal co-ordination working } \\
\text { well. }\end{array}$ & $\begin{array}{l}\text { Council of Senior Civil Servants not yet created, horizontal } \\
\text { co-ordination mechanism not sufficiently formalised, lack of a } \\
\text { uniform information exchange system. }\end{array}$ \\
\hline Lithuania & $\begin{array}{l}\text { Most institutions created, proper structures created in the line } \\
\text { ministries. }\end{array}$ & $\begin{array}{l}\text { Integration strategy, training strategy and information strategy } \\
\text { still under preparation. }\end{array}$ \\
\hline Poland & $\begin{array}{l}\text { Presence of EI units in all ministries, high level central } \\
\text { co-ordination function (direct involvement of the Prime } \\
\text { Minister). }\end{array}$ & Lack of qualified staff and fundamental equipment. \\
\hline Romania & $\begin{array}{l}\text { Existence of a coherent institutional system for managing all } \\
\text { aspects of EU affairs, coherent political approach, stability of } \\
\text { the institutional system. }\end{array}$ & $\begin{array}{l}\text { Weakness in co-operation and communication between } \\
\text { institutions, lack of specialised personnel, lack of } \\
\text { inter-institutional dialogue with EU Members and candidate } \\
\text { Members, insufficient organisational capacity and lack of } \\
\text { flexibility in ministries to adapt their working method to EU } \\
\text { requirements. }\end{array}$ \\
\hline Slovakia & Not answered. & Not answered. \\
\hline Slovenia & Not answered. & Not answered. \\
\hline
\end{tabular}


CCNM/SIGMA/PUMA(98)39

\subsection{Administrative Reform and European Integration: Part I}

Issue: Country

Existence of Special Unit for Administrative Reform

\begin{tabular}{|l|}
\hline Bulgaria \\
\hline Czech Republic \\
\hline Estonia \\
\end{tabular}

\begin{tabular}{|l|l|}
\hline Hungary & \\
\hline Latvia & \\
\hline
\end{tabular}

\begin{tabular}{l|l}
\hline Lithuania & $\begin{array}{l}\text { Ministry for Public Administration Reforms } \\
\text { and Municipalities. }\end{array}$
\end{tabular}

\begin{tabular}{|l|l} 
& \\
\hline Poland & Dep \\
& i \\
\hline
\end{tabular}

Romania

Department for Public Administration reform

in the Prime Minister's Office.

Government of Romania, local government

reform clearly assigned, central government reform managed by a steering committee.

\begin{tabular}{|l|l|}
\hline Slovakia & Not answered. \\
\hline Slovenia & Not answered. \\
\hline
\end{tabular}

\section{Interrelations Between Structures for}

Administrative Reform and European

$$
\text { Integration }
$$

Ministry for State Administration

represented in the Council for EI and in the

Inter-ministerial Committee.

Not answered.

Only as part of relations between ministries

and the Office for EI.

Office of the Government Commissioner

participated in the elaboration of the training

strategy.

Co-ordination with the EIB, mechanisms

being developed.

Two vice-ministers of the Ministry for PAR

are members of the Delegation on

Preparation for EU membership negotiation.

Not answered.

Permanent co-operation and partnership.

Not answered.

Not answered.
Substantive Links Between Administrative

Reform and European Integration

Two areas seen as closely linked, however, no institutional overlap so far.

Following the avis, work has started on the

development of new procedures to create a more effective administration.

Areas: Training of civil servants, institution building and enforcement of legislation.

Public administration reform is seen as one aspect of

Hungary's preparation for EU membership.

Under discussion.

Creation of special structures for European integration.

Not answered.

So far mainly regarding local government reform,

trying to adapt Romanian local authority structures to European standards.

Not answered.

Not answered. 


\subsection{Administrative Reform and European Integration: Part II}

\begin{tabular}{|c|c|c|c|}
\hline Issue: Country & $\begin{array}{l}\text { Potential Problems for the European } \\
\text { Integration Process Related } \\
\text { to Administrative Reform }\end{array}$ & Cause of Problems & $\begin{array}{l}\text { Expected Developments in } \\
\text { Administrative Reform }\end{array}$ \\
\hline Bulgaria & $\begin{array}{l}\text { General weakness of institutional and } \\
\text { administrative structures needs to be addressed. }\end{array}$ & $\begin{array}{l}\text { Several types of problems, but the overriding } \\
\text { problem is the lack of financial means. }\end{array}$ & $\begin{array}{l}\text { Administrative reform measures under } \\
\text { development, has been earmarked as a priority } \\
\text { area. }\end{array}$ \\
\hline Czech Republic & Not answered. & Not answered. & Not answered. \\
\hline Estonia & $\begin{array}{l}\text { Not significant, potential problems will be dealt } \\
\text { with as part of the institution building process. }\end{array}$ & $\begin{array}{l}\text { Complexity of building up a new institutional } \\
\text { system. }\end{array}$ & $\begin{array}{l}\text { Training of civil servants, institution building } \\
\text { and enforcement of legislation. }\end{array}$ \\
\hline Hungary & $\begin{array}{l}\text { Lack of adequate level of training for civil } \\
\text { servants. }\end{array}$ & $\begin{array}{l}\text { Improvement of quality of human resources, } \\
\text { improving decision-making and implementation } \\
\text { processes. }\end{array}$ & $\begin{array}{l}\text { Next phase of the administrative reform process } \\
\text { in line with EU requirements, stress on } \\
\text { implementation, co-ordination, EI training, } \\
\text { improvement of management. }\end{array}$ \\
\hline Latvia & $\begin{array}{l}\text { Problems in the civil service are complex and } \\
\text { serious, relate to most aspects of policy-making } \\
\text { and internal organisation. }\end{array}$ & $\begin{array}{l}\text { Complexity of building up a new institutional } \\
\text { system, difficult to isolate what are the main } \\
\text { causes. }\end{array}$ & $\begin{array}{l}\text { Strategy for the implementation of PA reform } \\
\text { under revision, rationalisation to structures } \\
\text { should free resources to bring about } \\
\text { improvements, Regulatory impact analysis } \\
\text { system planned. }\end{array}$ \\
\hline Lithuania & $\begin{array}{l}\text { Lack of expert EI staff in the administration and } \\
\text { the judiciary. }\end{array}$ & Human resources and financial. & $\begin{array}{l}\text { The accession and training strategy should } \\
\text { provide the basis to address the lack of human } \\
\text { resources. }\end{array}$ \\
\hline Poland & Not clear. & Not answered. & Not answered. \\
\hline Romania & $\begin{array}{l}\text { Serious weaknesses at central and local } \\
\text { government level, Romanian government is in } \\
\text { the process of addressing these. }\end{array}$ & $\begin{array}{l}\text { Financial and technical causes, mainly due to a } \\
\text { lack of experience and training. Need to create a } \\
\text { new administrative culture. }\end{array}$ & $\begin{array}{l}\text { Ambitious legislative reform programme, for the } \\
\text { time being with priority for local government } \\
\text { reform. }\end{array}$ \\
\hline Slovakia & Not answered. & Not answered. & Not answered. \\
\hline Slovenia & Not answered. & Not answered. & Not answered. \\
\hline
\end{tabular}


Chapter 2: Meeting the Challenges of Accession

By Les Metcalfe ${ }^{4}$

4. Les Metcalfe is Professor of Public Management at the European Institute of Public Administration (EIPA) in Maastricht, Netherlands. 


\section{Introduction: Willing and Able?}

99. The conclusion of the 1996 Inter-Governmental Conference (IGC, Maastricht II) at the Amsterdam Summit in July 1997 marked a turning point in the development of the European Union which has particular relevance to the candidate countries of Central and Eastern Europe. The Amsterdam Treaty which was agreed at the Summit does not contain dramatic new initiatives - indeed it has been criticised for lack of vision and ambition. Nevertheless, it has great importance. It was previously agreed that its conclusion would act as a trigger for the start of the next phase of enlargement negotiations. The success or failure of accession negotiations is a matter of supreme importance to the candidate countries from the standpoint of their political stability and long-term economic performance. Hence, the strong reactions when the Commission recently gave its Opinion that accession negotiations should begin first with the Czech Republic, Estonia, Hungary, Poland and Slovenia (plus Cyprus), and only at a later stage with Bulgaria, Latvia, Lithuania, Romania and Slovakia. The assumption is that negotiations will open early 1998.

100. The main concern of this paper is the management capacities needed by the governments of Central and East European countries to meet the challenges of accession to the European Union. In May 1997, the EU Dutch Presidency underlined the importance of this dimension of the forthcoming enlargement of the EU with a conference on "Governance and European Integration" which highlighted questions of governmental effectiveness and reliability. Up to now, it has been the political and administrative dimensions of accession that have attracted most attention. But with the recent publication of the Commission's Opinions on the candidate countries and the presentation of Agenda 2000, it has become impossible to escape the hard practical questions about how well equipped the candidate countries are to cope with the combination of managing the accession process and subsequently meeting the demands of membership. What capacities do they have now? What capacities do they need? What strategy should be followed in order to develop the requisite capacities?

101. In principle, membership of the European Union is open to all countries with a European identity that are willing and able to meet the membership requirements. The combination of willingness and ability is important. There is little doubt about the willingness of CEECs to become Members of the European Union. As Hans van den Broek, the Commissioner principally responsible for the enlargement observed in the first issue of Thesis-A Journal of Foreign Policy Issues, "the waiting room is crowded" (Van den Broek, 1997, p. 8). There is obvious impatience on the part of CEECs to join the EU. This is fuelled by excessively high expectations of the scale of benefits that EU membership will bring, as well as unrealistic assumptions about the pace at which enlargement can proceed. For, at present, the stumbling block is the ability of all CEECs to cope with the complex and demanding requirements of membership.

102. EU membership brings costs as well as benefits. Some of the most important costs stem from the obligation to implement a widening range of European policies and to participate in the formulation new ones, as well as the revision of existing one as needs and circumstances change. Reliable and effective administrations are essential means to these ends. If the main issue in the previous enlargement was willingness (Switzerland and Norway decided not to join), this time it is ability-the capacity to cope with the obligations of membership. The candidate countries have to prove that they are able as well as willing to fulfil the requirements of membership. Equipping national administrations to take on these new and difficult tasks involves a sustained commitment to public management reform and a sizeable investment in reorganisation. Transformations of this scale and complexity cannot be accomplished quickly or easily. The candidate countries will have to invest time and effort in capacity-building. 
103. The criteria and conditions of EU membership for CEECs were set out at the Copenhagen Summit in June 1993:

- Stability of institutions guaranteeing democracy, the rule of law and human rights;

- Respect for and protection of minorities;

- The existence of a functioning market economy;

- The capacity to cope with competitive pressure and market forces within the Union;

- The ability to adhere to the aims of political, economic and monetary union.

104. Underpinning all of these is an assumption that political and economic progress will be matched by appropriate capacity-building measures. New systems and structures have to be created and staff have to be developed to make them work reliably and effectively. There is some danger that the implications of this seemingly innocuous statement are not taken seriously enough. The management challenges of EU membership are frequently underestimated and often misunderstood. Although there are political concerns about sovereignty and threats to national identity, membership requires more not less of national administrations. The limited capacities of the EU institutions means that a great deal of the work of managing European policies is the responsibility of other levels of government. The integration process makes increasingly heavy demands on the administrations of the Member States.

\section{Challenges and Capacities — The Internal Management of EU Relations}

105. The basic approach of this analysis is to consider the management challenges that the candidate countries face and the capacities they need to meet them. Although there is a lack of detailed comparative information, there is little doubt that the challenge is a considerable one. There is a large disparity between the existing capacities of the administrations of the candidate countries and the demands that will be placed on them during the accession process and in the post-entry period. The question is what strategies for capacity development should be adopted in order to close the gap progressively in the future.

106. There is no standard answer to this question. All candidate countries are different in terms of economic strengths and weaknesses and in the geopolitical opportunities and threats they face. Countries have different priorities and problems and have established different kinds of administrative and political machinery for setting objectives and managing their negotiations with the EU. Internal political, economic and administrative variations are reflected in a diversity of institutional forms at the national level. The responses to the SIGMA questionnaire survey (See Chapter 1, Annex 1) illustrate this diversity. Despite these national differences, all CEECs must deal with some common challenges as they approach accession negotiations. The solutions they develop are bound to show similarities. All countries have to come to terms with the same external set of European institutions and procedures. They must also measure up to the same conditions and criteria if they are to be successful in their quest for EU membership. In the process they must work with the Commission as well as developing and maintaining relationships with the Member States individually, and collectively through the Council of Ministers, and with the European Parliament.

107. The capacities needed to secure accession and make European policies work are of various kinds. Some are operational management capacities, specific to very technical areas of policy implementation. Expert knowledge and specialist skills are needed in difference branches of agriculture, in transport, in dealing with environmental policies etc. Managing in such fields means becoming part of a policy network or regime and liaising with professional colleagues in the same field in other countries. 
Often these are regimes for the management of regulatory policies (Majone, 1996). There are highly developed networks of relationships in numerous economic policy fields and, increasingly, for second and third pillar ${ }^{5}$ policies also.

108. Other, higher-level capacities are relevant to the performance of a government as a whole and to making crucial policy choices, such as securing entry to the EU. It has been argued that dealing effectively with these high-level problems of governance calls for a new type of senior civil service which will not be developed within the framework of current New Public Management reforms (Dror, 1995). For conventional definitions of management, this is true. However, it would be wrong to conclude that expertise in management is not required at this level. Management is usually defined as getting things done through other people; public management is getting things done through other organisations. Different kinds of management skills and expertise are needed to deal with management tasks at the interorganisational level. These include co-ordinating and integrating the work of different organisations involved in managing public policies. They also include the ability to design and develop new organisations and management systems that work effectively across organisational and national boundaries. In doing so, it is necessary to understand the rivalries and overcome the centrifugal tendencies of bureaucratic politics, as well as counter other sources of organisational resistance to change within and between organisations. At the interorganisational level, there is no sharp distinction between governance and public management. They are simply two sides of the same coin. The construction of new systems and structures of governance, such as those involved in the adaptation of a national administration to meet the conditions of EU membership, is the management of change on a grand scale.

109. Managing European affairs requires the development of an increasingly complex network of links extending outwards to the EU institutions and inwards to the domestic administration. The crucial management questions facing candidate countries are how to upgrade capacities for managing interdependence between the national and European levels. There is no blueprint for capacity development that applies across all countries. The circumstances of one country may make it vitally important to develop capacities for managing particular policies, while in others they may already exist. As the White Paper on the Single Market insisted, each country must take responsibility for formulating its own approach. Despite the differences, the accession process does call for the development of certain core competencies. The aim, here, is to identify the strategic issues common to all candidate countries and consider the options available to them as they engage in the accession process with a view to eventual EU membership.

110. Thinking particularly about the approach of CEECs to accession negotiations, it becomes clear that it is vitally important to keep in mind another type of capacity that is crucially important and in extremely short supply: capacity-building capacities. As well as knowing what kinds of capacities are needed to gear national administrations up to the tasks of EU accession and membership, it is essential to know how to build and develop those capacities. In large part, the development of these capacities is a matter of learning from experience. But that does not mean it should be purely trial and error. The experiences of other countries in the current and previous waves of accession can be taken into account and utilised. Of course, in the end, each country must make its own decisions about how to proceed. But the effectiveness with which it develops the right kinds of capacities to meet the challenges of accession depends significantly on the efficiency with which it learns to discriminate between what works and what does not work, drawing on its own experience and that of others. Capacity-building capacities require a

5. Second pillar policies concern common foreign and security policy; third pillar policies concern justice and home affairs. 
more sophisticated approach than either outright rejection ("not invented here") or naive imitation of what is done elsewhere. This paper attempts to set out a framework for "lesson-learning" and the more efficient application of the lessons of relevant experience.

\section{The Fourth Wave}

111. In a long-term perspective, the incorporation of CEECs in the EU is the fourth wave of enlargement. The first, westward, enlargement, brought in Denmark, Ireland and the UK. The second, southern, enlargement, added Greece, Portugal and Spain. The third wave was the EFTA, or northern, enlargement to include Finland, Sweden and Austria (if Austria can be regarded as an honorary Nordic country). With each of these waves of enlargement, the candidate countries have had to surmount a higher threshold of political obligations and administrative responsibilities. In substance, this is non-negotiable. A basic condition of membership is that each new set of candidate countries accepts and takes account of the advances in integration made by the established Member States. This has meant that over time prospective Member States have had to make greater investments to strengthen their administrative capacities and adapt their political and administrative infrastructure to the increased levels of European integration.

112. The fourth, eastern, wave of enlargement will be the most difficult ever undertaken both for the candidate countries and for the EU itself. There are three main sources of complexity. The first is simply the number of countries involved. Though, in principle, each country negotiates its terms of entry independently, there are obvious problems in coping with so many candidates. The procedures for entry have been developed through previous accession negotiations, though they always have to be adapted to meet new circumstances. The development of the basic framework of accession negotiations and some of the specific innovations in the current round of enlargement are discussed in Nicolaides and Raja Boean (1997). The second source of complexity are the very real difficulties of meeting the Copenhagen criteria and developing the management capacities needed to sustain governmental performance as a Member State. Candidate countries have a great deal to do in order to bring their administrative systems and governance structures up to standard. The threshold of membership requirements has moved up even further since the relatively easy incorporation of Austria, Finland and Sweden. Before any new countries join, the price of entry will rise even higher as current commitments to further integration are confirmed in the coming years.

113. Third, on the side of the EU, it is clear that institutional reform is indispensable to the prospective enlargement. The EU has outgrown the institutional framework that was originally created to serve the limited needs of six Member States. But it has demonstrated little capacity for structural reform. The term "absorption capacity" which has come into popular use fails to reflect the complexity of the structural changes that are necessary for expansion to something close to twice the present membership without loss of effectiveness. Though it is not part of the purpose of this paper to discuss it, it is relevant to note that the EU has a significant "management deficit" which urgently need to be resolved. The 1996 IGC largely avoided these difficult issues of institutional reform despite the fact that it was specifically called upon to address them. The task of dealing with institutional deficiencies and weaknesses cannot be postponed for long without seriously damaging the functioning of the system as it is and disrupting the enlargement process. There is no denying the political difficulties this will raise among the Member States and the EU institutions. Nevertheless, the need for fundamental reform of major policies and institutions is inescapable. Oddly, this means that the candidate countries are negotiating to join a system which will be changed in some quite unpredictable ways by their incorporation within it. 


\section{4.}

\section{The (Reinforced) Pre-Accession Strategy}

114. The circumstances described above make the forthcoming enlargement process markedly different from the previous waves. The difficulties were recognised by the launching of a pre-accession strategy at the Essen Summit (December 1994). The four main elements of the pre-accession strategy are the Europe agreements, the structured relationship (structural dialogue) with the institutions of the Union, the Phare Programme and the programme based on the Commission's White Paper for alignment with the internal market. They are all different in scope and purpose and have evolved over time. The Europe agreements are association agreements with individual governments. The structured relationship is a framework for a multilateral dialogue between the associated countries as a group and the institutions of the EU to build mutual trust and explore areas of common interest. Phare is the main source of financial assistance in the pre-accession strategy. The White Paper programme is geared to go beyond approximation of internal market legislation to prompt the development of administrative capacities needed to implement them.

115. These four elements are intended to be included in a modified and more coherent form in the reinforced pre-accession strategy set out in the Commission's Agenda 2000 document (see especially Vol. II , pages 3-12). It is worth quoting the final paragraph which gives an indication of the scale and ambition of the task ahead:

"The next enlargement, unlike the previous ones, is forcing the European Union to link, in an overall approach as provided by the reinforced pre-accession strategy, the instruments granting aid to all the applicant countries and the conduct of the negotiations, irrespective of the date when each applicant country will be involved, so as to give cohesion to the entire exercise. Such a reinforced pre-accession strategy, if carried out well, will give all parties a guarantee of a well-prepared accession and will facilitate the solution of the problems raised by enlargement by avoiding systematic recourse to long transition periods, which could jeopardise the Community acquis and the cohesion of the Union."

(Agenda 2000, Vol. II, p.12, European Commission DOC/97/7).

116. Coherence is required at the level of each candidate country. Each must take on responsibility for adapting or developing its own systems and structures to meet the requirements of negotiating accession. Coherence is also required across all candidate countries to ensure that the whole accession process is intelligible, orderly and proceeds in a co-ordinated way. An important side-effect of managing the accession process coherently is that thorough preparation prior to accession will minimise the need for numerous, long transition periods which would subsequently complicate and disrupt the management of EU policies.

117. One aspect of this reinforced pre-accession strategy was announced previously; the reorientation of the Phare Programme. This has been described in broad terms as a switch from a demand-driven to an accession-driven approach. The selection, management and evaluation of projects will be geared to promoting the readiness of candidate countries for accession. In order to promote greater coherence at the national level, the intention is to have fewer but larger projects in each country. Projects will be selected on the basis of meeting needs identified in the Commission's Opinion. The management of projects will be delegated to the government in the country concerned as far as possible, with the Commission establishing a monitoring and accountability framework. This change not only implies the gradual acceptance of more responsibility by candidate governments but also a more co-ordinated and disciplined approach to management on the side of the Commission services. Reforms of the Commission's internal financial management are intended to support this new direction. 
118. Coherence across all candidate countries has been addressed from another angle. Allowing for the differences from country to country in problems and priorities, Agenda 2000 identified "institution-building" and "aligning economic activity with Community standards" as the two common themes of the reinforced accession strategy. The former reflects a recognition that approximation of laws is only a first step down the road to implementing the acquis. Implementation requires a public administration infrastructure with the skills, structures and systems needed to ensure compliance with EU standards and requirements. Aligning economic activities with Community standards will require substantial new investment. Without new physical capital investment, long transition periods and many exemptions from standards would probably be conceded. This, again, has implications for public administration because the management of regulatory policies requires the authorities responsible to build new relationships with the businesses concerned.

119. Even if negotiations do begin early in early 1998, the most optimistic target dates for entry for any new Member States would be 2002. But it is more than likely that accession negotiations will take longer. In any case, it might be said that the process has already been underway for some years, though the signing of association agreements with individual countries and the creation of the structured relationship to bring the associated countries within a multilateral framework of dialogue with the EU institutions and the Member States. Important though these are in substantive and symbolic terms, they are only preliminaries. There is still a long way to go. Nothing will be gained by underestimating what accession requires of candidate countries or by building up unrealistic expectations about how quickly membership can be achieved. A quick entry decision with qualifications and extended transition periods might actually have negative long-term effects. The important task is not fixing a specific date for entry but ensuring that candidate countries are adequately equipped for membership.

120. Although the enlargement of the EU can be seen as a succession of waves, negotiations are conducted separately with each applicant country. This does not mean there is no co-ordination and comparison among the applicant countries or within the EU institutions. On the contrary, there is considerable sensitivity to the relative progress that is made. The recent responses to the Commission's Opinions on the current candidates illustrates this quite clearly. In the end, decisions will be made and agreements reached with each country individually. But before that time arrives, a good deal of preparatory work has to be done with the EU setting up parallel processes for dealing with the applications of the candidates. Identifying a group of countries is a step towards the orderly management of the accession process.

\section{Managing Accession Negotiations: Getting to the Table}

121. Before considering strategies for capacity building as such, it is necessary to make some general comments about the whole process of managing accession negotiations. As the discussion above illustrates, accession negotiations are far removed from the popular stereotype of deals struck around the bargaining table by individuals who snatch victory from the jaws of defeat by their persuasiveness, shrewdness and force of personality or, alternatively, are outmanoeuvred by the low, cunning and underhand tactics of their adversaries. In such a context, management would seem to have little to do with success or failure. But the context of accession negotiations is quite different. The success of accession negotiations depends critically on good management.

122. The reason is the sheer complexity of the task. Chief negotiators are not individuals acting alone; it is impossible for any single individual to oversee, let alone control the whole process. Nor is the management of accession negotiations a purely diplomatic function be carried out by a foreign ministry. Chief negotiators are leaders of negotiating teams. Success depends on sustained concerted efforts and 
well-organised teamwork. This does not eliminate the influence of personality, but it does limit it. Foreign ministries usually take a leading role, but the wide ramifications of EU membership mean that many other ministries have a legitimate interest and seek to play a role. This forces a whole process of reorganisation on ministries and the relations among them. If foreign ministries have difficulty in adapting to the new demands from the EU environment, this will have unsettling effects throughout government (Christensen, 1996). Blurring the boundary between foreign and domestic policy is one of the distinctive features of the accession process. Having to negotiate on so many inter-related issues, which might previously have been regarded as independent of each other, greatly increases the need for careful preparation and closer co-ordination. Any administrative weaknesses or unresolved political differences are almost certain to come to the surface when commitments to irrevocable national positions have to be made. European integration should lead to the active involvement and effective co-operation of individuals from many different parts of government. Ensuring that this actually happens calls for greatly increased capacities within the governments of the candidate countries. The vast bulk of the time and effort that goes into negotiations is in "getting to the table" (Stein, 1989). Thorough preparation is crucial and this means that contrary to the popular stereotype negotiators spend most of their time negotiating with their own side. The final phase around the bargaining table is the tip of the negotiating iceberg.

123. It is useful to differentiate between internal processes of preparation and external processes of pre-negotiation. Intragovernmental preparation takes place to ensure that negotiators are well briefed and able to represent national interests effectively when they eventually do reach the negotiating table. Preparation involves all the detailed technical analysis required to understand issues and problems. It also includes assessing the implications of different policy options before determining national negotiating objectives, strategies and tactics. A very large part of the work that goes into accession negotiations is "homework" in this sense. Indeed, senior negotiators involved in previous waves of enlargement have commented that they spent much more of their time negotiating inside their own government to reduce areas of uncertainty and resolve internal differences rather than in actually representing their governments in negotiations.

124. Side by side with intragovernmental preparation, there is an external process of pre-negotiation with counterparts in the negotiating process to establish the framework and basic agenda of the negotiations themselves. Pre-negotiation establishes the environment in which negotiations take place without determining their outcomes. The institution of the structured dialogue and the upcoming European Conference of 12 March 1998 appear to provide the elements of a pre-negotiation framework; so also do the Accession Partnerships which are discussed below in Section 6. Preparation and pre-negotiation are interactive. Negotiators must always be aware of the ways in which developments in the negotiating environment may influence internal preparations and vice versa. Although Agenda 2000 has established some general parameters, there are still many unanswered questions on the pre-negotiation agenda. How, for instance, will Accession Partnerships be structured and organised?

125. Negotiators must take account of two other distinctive features of accession negotiations. First, the range of issues and interests involved is wide and increasing. Successful negotiations require teamwork to ensure that all relevant subjects are covered and differences and conflicts sufficiently reconciled for negotiators to present a consistent view of national interests. There is already some experience of this. All CEECs have had to face this problem in deciding how to assign responsibilities for specific aspects of the White Paper. Since there are important areas of interdependence, after deciding on the division of labour among ministries and other organisations, they have also faced the problem of ensuring co-ordination. What has been learned from this experience? Second, because of the heavy bias in thinking about negotiations towards competitive strategies and win/lose dynamics, the fact that accession negotiations are principally about integration may be lost sight of. While it is always possible to see elements of competition and conflict in negotiations, the distinctive feature of accession negotiations is 
that their primary aims are to bring candidate countries up to the standards needed to be effective Members of the EU and define the terms on which they can join. In certain respects, this makes the negotiations more like a management audit than a conventional international negotiation. Though, it must be added at once that they hardly fit the conventional image of a management audit either.

126. The way the negotations were set out reflects the specific circumstances of CEECs as countries undergoing major politico-economic transition-establishing new constitutional frameworks, systems of government and undergoing economic transformation. Not only is this wave the biggest in terms of the number of countries seeking admission, but there is a very large gap between the limited governance and administrative capacities of CEECs and the increased demands that the rapid progress of integration in the last decade places on the administrative capacities of Member States. Tight financial and budgetary constraints preclude a large increase in resources. The situation is further complicated by the fact that the fourth wave of enlargement cannot be accommodated in the existing institutional framework of the EU. Major structural reform is necessary. The 1996 IGC did not address this issue although this is what it was intended to do.

\section{Designing Accession Partnerships}

127. Agenda 2000 has introduced the concept of "Accession Partnerships" as a key element in the reinforced pre-accession process. It is useful to consider more closely what it may mean in practice, both in its intrinsic importance and as an example of how capacity-building capacities might be strengthened. The capacities concerned are design capacities for re-defining CEEC and EU roles in the accession process.

128. An Accession Partnership is intended to bring together all forms of assistance available to each of the candidate countries in a coherent way and to focus their use on meeting the priorities of implementing the acquis communautaire. In future, the choice of projects and the development of programmes should reflect the specific needs and circumstances of each of the candidate countries. The intention is to develop country programmes during 1997 and 1998 within the new Accession Partnership framework which will enable each country to move more quickly and effectively towards building the capacities to cope with the obligations of EU membership.

129. Thus, Accession Partnerships are intended to make a lasting contribution to the "Europeanisation" of governance in the candidate countries. Their purpose is to organise and accelerate the process of equipping candidate countries to meet the conditions of EU membership and enabling them to function as effective Member States thereafter. Europeanisation is not something which ends with accession. It is a continuing part of the functioning of each Member State. Membership does not diminish demands on national governments, it increases them. Contrary to common misperceptions, the progress of European integration demands more of national governments rather than less. In the multi-level system of governance developing in Europe, the Member States have to cope with the commitments and workloads of additional European policies. Countries in the process of accession have to gear themselves up to take on the same commitments, as well as prepare for future ones.

130. Symbolically, Accession Partnerships represent the beginning of a new phase in the relationship of CEECs with the EU as they move towards the achievement of membership in the coming years. But what is the added value? Looking beyond political symbolism, it is important to consider how the Accession Partnerships will make a positive difference in practice to the way accession is managed. Otherwise, there is a danger that the term will be no more than empty political rhetoric. Worse, it may become a source of confusion because ambiguities and misunderstandings obstruct the design of effective 
working relationships. Different interpretations of what "partnership" means can lead to frustration and unproductive conflict. Clarity and consistency are all the more important because this new formulation is a response to dissatisfaction. Management practices in the past have failed to cope satisfactorily with the inherent complexity of the task of steering the accession process and co-ordinating the efforts of the numerous of organisational actors involved.

131. There is, at least, the basis for progress. The general principles that are intended to guide Accession Partnerships seem clear. An assumption of joint responsibility and shared commitment for capacity development on the part of each of the candidate governments and the Commission is implicit in the concept of partnership itself. Better organisation of both partners is a prerequisite of a constructive partnership. Neither the Commission nor each candidate government is a single monolithic entity. In order to ensure that they can work together, each needs to strengthen its own internal organisation. On the side of the Commission, there is an acknowledgement of the need for a more coherent approach to relationships with candidate countries than there has been in the past. The internal management of the Commission needs to be changed to strengthen the mutual co-ordination of different Directorate Generals' (DGs) activities in dealing with each country. This does not preclude decentralisation and the development of separate links with a candidate country by different DGs. What it entails is greater commitment to co-ordination within the Commission in order to ensure that different initiatives are part of a recognisable joint approach which will not degenerate into confusion and conflict because of overlap, duplication or unrecognised gaps and omissions.

132. Just as it is important that the Commission speaks with one voice in dealing with a particular country, so on the other side it is essential for a national government to speak with one voice in its dealings with the Commission and other partners in the accession process. Intragovernmental co-ordination is vitally important to ensure that national interests are well defined and effectively represented. If anything, national co-ordination is a more complex task than it is for the Commission because of the number and diversity of domestic interests involved. (Though it must be pointed out that the Commission must develop as many co-ordination subsystems between DGs as there are candidate countries!). Moreover, there is the added complexity that co-ordination is required for both European policy formulation purposes and also for the implementation of agreed programmes and projects. Finally, Accession Partnerships require a more coherent approach on the side of the candidate countries themselves. The underlying aim is gradually to devolve more responsibility to the CEEC governments for designing future programmes which will provide the framework for the selection and management of assistance projects.

133. The internal organisation of the Commission in its dealings with each country and the internal organisation of the national governments themselves for dealing with the Commission are prerequisites of the effectiveness of Accession Partnerships. But the function of Accession Partnerships per se is to assist candidate countries to organise the interface between the national and EU levels and to assist them in developing capacities to perform the management tasks that arise at the boundaries. This raises questions of organisation and management at a different level.

\section{Partnership Models}

134. Bureaucracies have a bias towards standardisation. Given the number of candidate countries, there will probably be pressures on the Commission to treat all of them in the same way. Though this would be administratively convenient and, outwardly, fair, it would not necessarily be effective. It would fail to reflect the diversity of the candidate countries. They have different needs - as partially reflected in the Commission's Opinions. And, the design of Accession Partnerships should be adapted to take account 
of these differences. This does not mean that they should be dealt with in an unsystematic ad hoc way. An Accession Partnership is a strategic alliance in which there is a gradual shift of responsibility towards the candidate government. Ensuring its effectiveness as a mode of management involves clarifying the respective roles of the Commission and the candidate governments. Since Accession Partnerships are still at an early stage of development, it may be worth setting out some options for consideration and discussion of the ways in which these requirements might be met. Only the broad outlines will be presented. The fine structure of actual cases consists of networks of dozens of organisations.

135. Without making any claim to be exhaustive or original, it is useful to consider three partnership models: principal-agent, purchaser-provider and professional-client. First, partnerships are sometimes based on a principal-agent model. In essence this is a hierarchical relationship in which objectives and policies are set by the principal and implementation by the agent is closely supervised and monitored. Standard management-by-objectives models and methods provide the means of making this type of partnership work. Since compliance with large volumes of EU legislation is an essential part of the accession process, partnerships based on relationships of this kind are important. But the maintenance of hierarchical relationship in which candidate countries are junior partners is only part - and presumably a diminishing part — of Accession Partnerships.

136. A second model, very familiar from many recent reforms of public administration throughout the world is a purchaser-provider partnership. This is a quasi-commercial relationship in which partners agree a performance contract based on payment for services. This does not apply directly to the relationships between the Commission and CEECs. There is not a customer-supplier relationship between them on which a performance contract might be based. There is, however, a more complex web of exchange partnerships in which services are provided to CEECs (on a more or less commercial basis by third parties) with the Commission playing a sponsorship role. One of the drawbacks of a purchaser-provider design for Accession Partnerships is that the contract approach tends to overstate the degree of certainty that can be written into agreements and, consequently, leads to an underestimation of the extent to which contract performance has to be continuously monitored and managed. Though there are justifiable reservations about whether purchaser-provider relationships are, or should be, the main basis for Accession Partnerships, they are certainly an important component of the whole process of capacity development.

137. A third partnership model distinct from principal-agent and purchaser-provider is a professional-client model. Here the relationship is based on diagnosis of client needs and the application of professional expertise to solve problems and upgrade capacities. A professional-client partnership involves the management of an awkward mixture of professional autonomy and client commitment. This is particularly the case when developing the capacities of the client system is one of the key objectives of the partnership. The professional-client model of partnership is relevant in two perspectives. One is that there are many instances where an independent preliminary diagnosis of needs is an indispensable step in deciding what should be done, while the effectiveness of what is done depends on the commitment of the client. Principal-agent and purchaser-provider relationships are not appropriate here. The other perspective is based on the presumption that Accession Partnerships have a developmental dynamic. They are intended to build capacities and promote independence, not maintain dependence. Whereas principal-agent and purchaser-provider partnerships may be perfectly appropriate for managing specific tasks, a professional-client partnership provides a framework for strengthening capacity-building capacities. The intention is to move, over time, to greater delegation of responsibility to candidate countries for managing their own programmes. A professional-client partnership offers a more appropriate and flexible framework for increasing autonomy and enabling CEECs to take on more responsibilities in anticipation of membership. 
138. These partnership models are not mutually exclusive. There is no reason why they should not be combined in designing Accession Partnerships. Different combinations may be appropriate to different countries. Different combinations may be appropriate at different stages of the accession process in one country. From the standpoint of effective performance, perhaps the most important general observation is that in all cases the partners should understand and agree on the kind of relationship they are getting into. The basis of the Accession Partnership should be reviewed from time to time as capacities develop.

\section{Making Haste Slowly}

139. Some CEECs have been the targets of shock therapy and crash programmes intended to produce dramatic results very quickly. Whatever the merits of this approach in bringing about economic change, it is very doubtful whether it is the best way to produce lasting reforms of public management or build the capacities needed to secure and benefit from EU membership. There is always the danger that superficial progress cannot be sustained. Setbacks can be politically damaging and administratively demoralising.

140. A patient build-up of capacities reduces the chances of such setbacks and offers a more productive long-term prospect. The key to long-term success is a strategy carefully designed to keep an overall balance between the rate at which new capacities are developed and the rate at which additional European responsibilities are acquired. Attempting to accelerate the accession process by taking on more responsibilities than existing capacities can cope with increases the risk of overload and collapsing performance and has a damaging effect on a country's external image by making it appear an unreliable partner. Particularly where there is a need to shift to significantly higher level of performance - as there is for CEECs seeking accession to the EU-initial progress may seem unimpressive. "Making haste slowly" has less obvious political appeal than promising quick results, but it seems likely to provide a firmer foundation for long-term effectiveness.

141. The accompanying diagram suggests why a "make haste slowly" approach is appropriate for designing a capacity-building strategy. The presumption is that at low levels of capacity governmental networks are easily overloaded. A reform strategy should be carefully designed to keep an overall balance between the rate at which new capacities are developed and the rate at which new European responsibilities are acquired. Especially when the gradient is steep, overloading a governmental system can cause a collapse of performance and can act as a severe setback to the capacity-building process. 


\section{Capacity Development Strategies}

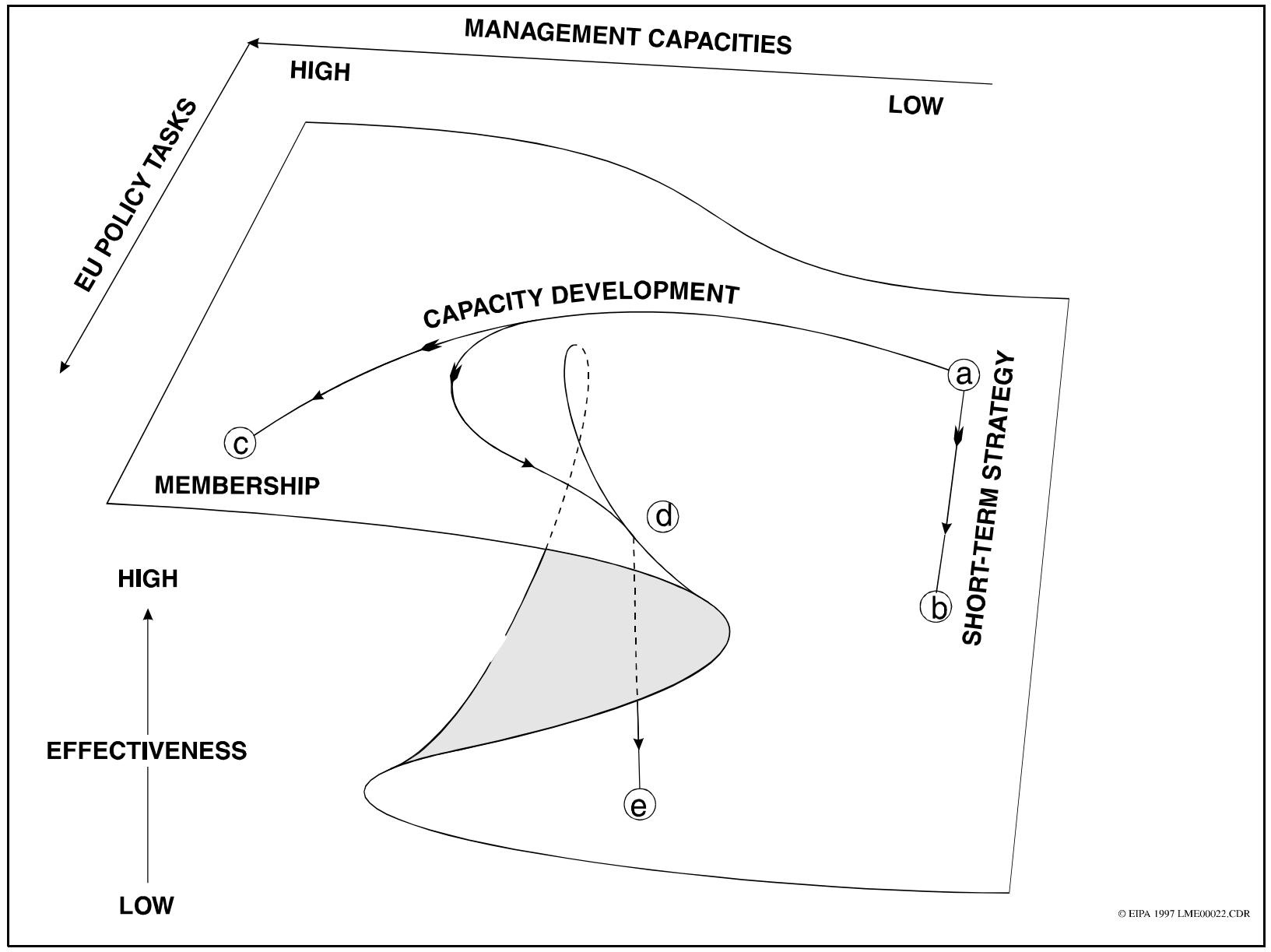

142. A short term strategy (a-b) leads to the uncritical acceptance of additional EU policy tasks without any significant effort to build capacities to cope with them. It achieves no gain in effectiveness. A competitive strategy (a-d-e), based on a shock therapy philosophy, produces rapid initial results before creating overload or a crash. A viable long term strategy (a-c) maintains a balance between the development of management capacities and the acquisition of EU policy responsibilities. Initial progress is liable to seem slow, but like an athlete in a progressive training regime a succession of "challenge response" cycles leads to enhanced performance without causing excessive stress or destructive overload.

\section{Five Conditions for Successful Reform}

143. Reform in government often starts with high expectations and ends in disarray and disappointment. One reason, often quoted, is bureaucratic resistance to change. Since some resistance is to be expected, reform strategies should be designed to take account of it either by overcoming it or circumventing it. We know enough about the main sources of resistance to change to be able to anticipate them and formulate ways of dealing with them.

144. More generally, poor results are usually attributed to lack of political will. The presumption is that political pressure, firmly applied, is all that is necessary to ensure that reforms are implemented. It is certainly the case that if there is no political commitment, reforms soon lose momentum. Lack of support at the top or divided political views about the direction of reform will undermine efforts to introduce 
changes. However, it is mistaken to conclude that political commitment is all that matters. Political will is necessary but not sufficient to guarantee the success of reforms.

145. What else is required? What conditions underpin successful reform? Effective reforms seem to depend on a combination of five conditions which are partly characteristics of the situation and partly the results of deliberate action by reformers and their political leaders. In summary form they are:

- External Pressure;

- Internal Dissatisfaction;

- A Reform Strategy;

- A Mechanism for Managing Reform;

- Feedback and Evaluation.

146. It is, to say the least, unusual for any organisation to embark on a major reorganisation or reform without some external pressure. In the case of CEECs, there is no doubt that all governments are under enormous pressure from domestic and international sources to introduce reforms which further the process of transition. Excessive external pressure, rather than lack of it, is the problem in all candidate countries.

147. External pressure on its own will achieve little unless there is also a sense of internal dissatisfaction. Internal dissatisfaction - a feeling that things could be done differently and done better - is essential to maintain the motivation for reform. Political will may be enough to initiate a reform. A widespread sense of dissatisfaction with the status quo helps to keep reform going. Importantly, exploiting internal dissatisfaction reduces resistance to change. If there is little sense of dissatisfaction, passive resistance will be enough to bring reforms to a standstill.

148. A combination of external pressure and internal dissatisfaction provides the motivation and energy for change without giving it a coherent purpose. A strategy of reform is also needed to give a clear general direction to reform. Membership of the EU and developing capacities to implement the acquis communautaire provide just such a direction. They point a definite way forward. Even so, they leave a great deal of scope for working out the details and setting the priorities of a reform strategy, to say nothing of the questions they raise about capacities for managing and implementing a strategy.

149. This leads to the next condition for successful reform: a mechanism for steering and managing the reform process. In modern government, reform is the management of change-change in organisations and change in the working relationships among networks of organisations. These are very complex and difficult changes to bring about. Passing laws achieves little if there is no capacity for doing detailed work and developing programmes that, step by step, move towards strategic objectives. The capacities required need not be in the form of a large organisation that centralises control. Instead a small group with clear political backing may work in a quite decentralised way. In the end, the success of reform depends on the commitment of those who have to implement them.

150. Finally, the fifth condition of successful reform is processes of feedback and evaluation. These are important politically as well as managerially. They can be used to give reforms political visibility and also provide those who are managerially responsible with the means of assessing progress. Reforms often lose momentum because over time they lose political visibility and support. Feedback and evaluation provide the flows of evidence and information which can be used to maintain internal and external support. Despite the difficulties, one of the advantages of accession is that it gives some definite and politically significant criteria to assess and reinforce progress in a self-organising reform process. 


\section{Defining a Capacity-Building Strategy}

151. In order to define a capacity-building strategy, it is important to set an agenda that establishes the key issues that are common to all the candidate countries. At this point, the question arises "What is the strategic objective?" Particularly in the situation following the announcement of the Commission's Opinions, the assumption seemed to be that in many cases the answer was "To achieve membership" or even "To achieve membership as quickly as possible". For the purpose of the present analysis, these seem to be too limited and perhaps even damaging as primary objectives. In what follows, it will be assumed that the appropriate strategic objective is to create the capacity to benefit from membership. Negotiating accession is an essential step in this process rather than an end in itself (Metcalfe, 1996).

152. From the perspective of a candidate country, a viable strategy depends on developing systems and structures to enable them to negotiate accession and manage membership as well as gearing up their administrations to implement current and future EU policies. To provide a stable long-term perspective on the management of accession, it is useful to distinguish three strands of a capacity-building strategy which aims at securing the long term benefits of EU membership:

1. Accession as a Project Management Process.

2. Accession as Preparation for Membership.

3. Accession and Domestic Public Management Reform.

\subsection{Accession as a Project Management Process}

153. It is useful to start by viewing the process of negotiating accession as an exercise in project management. Negotiating accession to the EU may be regarded as a self-contained task which is assigned to a specific group within the government of a candidate country. All applicant countries past and present, have established units and given them responsibility for leading the accession process. Such groups have to fit into a structure of government and a pattern of political responsibility. Carving out a role involves resolving problems of credibility and legitimacy with existing ministries and central government institutions. Continuous involvement with the accession process makes them the nucleus for the accumulation of experience and the development of expertise in dealing with European affairs. If the group or unit functions well, it gradually becomes the government's memory and main source of knowledge about what has been done and what is being done in the field of European integration. A group of this kind forms the basis for an effective negotiating team.

154. A project management perspective is a useful first approximation rather than the whole picture. Accession shares some important common features with a conventional project management approach. The basic one indicated above, is the creation of a single-minded team or task force which has the completion of the project as its main responsibility. Ideally, a group is established to perform a task from beginning to end and given clear terms of reference. In accession negotiations, this is a more accurate description of what is needed as the final stages are reached, than what can be expected earlier. The reality is that there is generally more than one focus within a national government. Foreign ministry involvement is essential; so, from a different angle, is finance ministry involvement. It is usual to create a specialist department or bureau for European integration; and given the high political priority attached to the exercise, there is generally a close link with the prime minister and/or president. It is impossible to say what is the best configuration. There is no "one-best-way" solution. However it is possible to say that with any configuration, it is very important to have an explicit understanding of the division of responsibilities between the different bodies, e.g. who is primarily responsible for ensuring coherence vis à vis the outside 
world and who for internal co-ordination. Coalition governments and coalition politics complicate these tasks, but one reason for stressing the relevance of a project management perspective is to drive home the importance of developing the capacities for settling these differences and resolving conflicts in the long-term national interest.

155. Applying a project management perspective helps to move in this direction by providing a common framework for judging effectiveness and systematically identifying obstacles and issues that have to be dealt with in steering a project effectively. In broad terms, project management utilises three sets of performance criteria: objectives, costs and time. A well-managed project has a clearly defined goal, a budget and a time-scale. The management task is to complete the project: "to standard, on time, and within budget". In accession negotiations, the management tasks are determined by the goal-the achievement of EU membership; a suitable time frame has to be established in the light of the resources available. The management task is to steer a course which makes best use of the resources to achieve the objectives within the time constraints. These criteria are interdependent. In an ideal world, budget commitments, completion dates and guarantees that standards will not slip can all be given in advance. In the real world, none of them can be guaranteed. The important questions revolve around the priorities among them. What happens to timetables if problems prove more intractable than expected? What if costs rise, or standards are difficult to reach? Project management does not provide ready-made answers to these questions, but it does provide tools and techniques for anticipating and steering a course which prevents crises from doing lasting damage. Most important, it provides a common framework for discussion within a national government which can help to prevent bureaucratic or coalition politics overriding serious evaluation of progress.

156. A good deal of recent debate about the progress of accession negotiations can be framed in these terms. Politically, the sensitive question is the timescale of accession. When will accession negotiations begin? What is the expected date for their completion? There are strong political pressures to speed up the process and shorten the timescale. Whatever the short-term political gains from doing so, ignoring other dimensions of effectiveness is liable to have damaging long-term effects. Costs and standards have been given far less consideration than they deserve. Rushing the process is liable to add to costs and to compromise standards. Whatever the temptations to seek a quick decision on the assumption that the problems can be sorted out afterwards, there is a danger that superficial consideration of the problems will result in major errors and reduced standards of performance that are exceedingly difficult to correct later. (Although the context is different, in principle, this is what is happening with European Monetary Union. The desire by countries to be included in the first round of membership and the efforts to maintain the original timetable led governments to incur the costs of heavy unemployment through the adoption of restrictive economic policies and then seek ways of lowering the standards that monetary union was intended to guarantee. Whatever the merits of Monetary Union in economic terms, as a project it is being poorly managed.)

157. The first important question for the management of accession is whether a stable project team can be assembled. Given the limited human resources and the highly specialised needs of the accession process, it is neither easy to recruit nor retain people of the right calibre. The next question is where such a team should be located in the machinery of government. The most usual answers to these questions have been to form a small project team within or closely linked to the foreign ministry. The logic of this is that it is foreign ministries that have the diplomatic skills and the established network of external relationships needed to deal with accession negotiations. But this is only one side of the picture. The accession process has complexities that do not usually figure in project management, particularly with regard to securing the full co-operation of relevant domestic ministries. One of the most important and difficult aspects of the accession process is the extent to which it blurs the boundaries between what is conventionally regarded as foreign policy and what is regarded as domestic policy. The success of an accession strategy depends 
heavily upon making use of knowledge and expertise across government. An effective accession project team must ensure that links are established among all the ministries and other organisations that should contribute to policy formulation or have a role to play in implementation.

158. A project team, however high-powered and wherever it is located in government, cannot take on the whole task of preparation and negotiation itself. It is only the nucleus around which capacities for managing accession are organised and deployed. A project team is the nerve centre which ensures the continuity of leadership and co-ordination of the process. But it does not possess all the knowledge and expertise needed to conduct successful accession negotiations. From the earliest stages, accession negotiations require much more extensive involvement by line ministries. The heavy burden of detailed technical work requires the inputs of specialists and experts in all the relevant policy fields. If expertise does not already exist, one of the responsibilities of the accession project team is to stimulate its development. In the short term, it may be possible to "borrow" or "buy-in" expertise but in the longer term, there is no substitute for developing in-house capacities. Importantly, this means that the project team at the centre has to play an active role in developing the domestic national network that will eventually take over the tasks of managing membership.

159. The responses to the SIGMA questionnaire have shown the steps that have already been taken in the CEECs to develop these networks. Sometimes this has been done by designating individuals as contact persons or establishing specialist units for European affairs within line ministries. As the volume of EU-related work grows, the importance of these boundary-spanning roles increases. It is also important that the domestic national network develops as a horizontal network in which priority is given to accurate and reliable two-way flows of information among ministries. Much of this can be done on a bilateral basis. A hierarchical structure of relationships is liable to restrict communication and lead to excessive dependence on hierarchical sources of information. In bureaucratic politics, information is power but a project team which attempts to act as a gatekeeper on European contacts or establish a monopoly of information is more likely to undermine than reinforce its credibility. Perhaps the main point to underline is that a project management approach should aim to make a decentralised system work rather than try to increase central control.

\subsection{Accession as Preparation for Membership}

160. Provided that the additional complexities that have just been discussed are allowed for, it is useful to think of the accession process as an exercise in project management. Pre-negotiation and preparation benefit from having a cohesive dedicated team with good links into the national administration as well as external relationships and access to political leaders. A project management approach can provide a good foundation for establishing a negotiating team which avoids serious errors and seizes opportunities even in the stressful, hyperactive atmosphere of accession negotiations.

161. This said, it is very important to recognise that creating a project management team is not all that needs to be done. At the same time as preparations are being made to negotiate accession, preparations for managing membership should begin. It might be argued that this is neither necessary nor wise. From a management standpoint, it might appear that it would be better to concentrate all resources on securing membership as quickly as possible and then move on sequentially to deal with membership. Given the limited human resources in candidate governments, this "one thing at a time" approach may seem sensible. It has often been supported from a political standpoint by the argument that preparing for membership is tactically unwise because it weakens the negotiating position of a candidate country. It suggests over-eagerness and appears as a concession. Whatever plausibility these arguments may have had 
in the previous wave of enlargement, they are much less relevant in the present one. The main focus of negotiations is not on willingness to join, but on ability to meet the heavy demands of membership.

162. Underlying the preference for a "one thing at a time" strategy, there is often a belief that the really difficult challenge facing candidate countries is securing membership. Securing membership becomes a political end in itself, rather than a means to the strategic objective of being in a position to benefit from membership. Once membership has been accomplished, it is assumed that life becomes easier. The opposite is the case. Securing membership, in other words, is not the end of the story. It is only the beginning of a new phase-an important event in a continuing process. Being a Member is, in some ways, more difficult and demanding than negotiating membership. A sound strategy for building capacities to cope with membership must take account of the permanent demands that membership brings and the temporary problems of the transition to membership. Concentrating solely on securing membership runs the risk of underestimating both and weakening rather than strengthening capacities in the long run.

163. Managing the transition from candidate to Member presents specific challenges. In broad terms there is a shift from bilateral negotiation with the EU to multilateral negotiation in the EU. This complicates the task of national representatives. Instead of having a single objective-membership-to provide a common point of reference, there are numerous objectives and competing concerns without any clear priorities among them. If anything, membership generates heavier loads than the accession process because national representatives have to be involved in all spheres of EU policy and not just those that are of direct national interest.

164. Deferring consideration of the needs of membership until the post-accession period may create false expectations that increase negative reactions to the culture shock of membership. The problem is like leading a team up a difficult mountain climb with all efforts and expectations focused on the peak above, only to make the demoralising discovery that the actual summit is very much higher. A specific problem of transition management is that heavier responsibilities have to be taken on at a time of reorganisation and, most probably, a loss of key personnel. The risks of a breakdown are increased by the fact that at this crucial turning point all new Member States must deal with the loss of a significant number of their most senior and expert personnel; particularly those with the skills and knowledge that equip them to work in the EU environment. Some will take up new posts in the European institutions. Some may go to a strengthened Permanent Representation in Brussels. Some may find employment in other EU-related organisations. Almost certainly some will be lost to government entirely. Even though CEECs are not in a position to have a "back-up crew," they should be aware of the likelihood of this transitional problem.

165. Advanced preparation for managing membership involves substantial investments in human resources and organisational development within the line ministries that have EU-related responsibilities for agriculture, transport, environment, industry, customs, etc. Since it takes considerable time to train and develop staff and to build or adapt the organisations that have to fulfil European and domestic responsibilities, there is a need for careful planning of the necessary capacity building programmes within these and other ministries.

166. Equally important as developing organisational capacities is the development of interorganisational capacities. European policies are often interdependent. They are not just parallel lines of policy that can be dealt with by individual ministries independently of each other. Taking account of policy interdependence requires co-ordination. Ministries must work together in the process of formulating national interests on a regular basis. To be effective in managing membership, ministries need to co-ordinate with each other as a matter of routine and also develop capacities for managing non-routine co-ordination problems. 
167. Establishing a special unit for "co-ordination" is not the solution to this problem, although specialist co-ordination units do have a useful role. The more important task is to build capacities for managing interdependence into line ministries themselves. Instead of equating co-ordination with external control or hierarchical supervision, the great bulk of the work of co-ordination should become part of the responsibility of the ministries which exercise policy responsibilities. For countries in the throes of rapid economic change and political turbulence, it may seem that this is asking too much, but it is extremely important to make the effort to build these capacities for managing conflicts internally. Failure to do so will certainly weaken the external negotiating position.

168. This does not exclude the possibility that foreign ministries, finance ministries, prime ministers' offices, cabinet offices or chancelleries play an important role in co-ordinating national positions. What it implies is that for higher level co-ordination units such as these to work well, the capacities for managing lower level co-ordination functions should be well established. If this is not the case, high-level co-ordinating institutions will be overloaded with a large number of ill-prepared proposals and specific problems which interfere with efforts to deal with broader issues. Ministers and senior officials will find their agendas blocked by huge numbers of detailed issues that could just as well be dealt with at a lower level of co-ordination if capacities were better developed.

169. The policy co-ordination scale set out in the diagram below provides a systematic way of identifying weaknesses in governmental co-ordination and points to ways of remedying them (Metcalfe, 1994). Given the importance of co-ordination to the effective management of both accession and membership, it is very important that deficiencies in, say, communication and consultation between ministries, or other lower level co-ordination functions, are identified and eliminated. But often politicians are inclined to adopt a top-down perspective and simply assume that all the levels of co-ordination described in this diagram are adequately provided. Since this is not the case in many of the existing Member States, it is extremely unlikely to be the case in the candidate countries. The diagram can be viewed as a series of steps that can be built from the bottom up. The effectiveness of higher levels of coordination depend on the firm establishment of those below. For instance, it is important in negotiations for representatives from different ministries to speak with one voice (Step 4). Good communication and consultation processes among ministries provide the basis for doing so (Steps 2 and 3).

\section{SETTING GOVERNMENT PRIORITIES}

\section{SETTING CENTRAL LIMITS}

\section{ARBITRATION OF CONFLICTS}

\section{CONCILIATION (MEDIATION)}

\section{SEARCH FOR AGREEMENT (CONSENSUS)}

\section{SPEAKING WITH ONE VOICE}

\section{CONSULTATION (FEEDBACK)}

\section{EXCHANGE OF INFORMATION (COMMUNICATION)}

\section{INDEPENDENT POLICY MAKING BY MINISTRIES}

170. There is, of course, no conflict between developing co-ordination capacities as part of the project management approach to managing accession and developing them to underpin the effective management of membership. But there are great risks in assuming a smooth transition from one to the other. The high 
pressure work of negotiating accession is liable to produce a reaction once the objective is attained. The loss of one specific focus and a clear common goal is likely to result in a loss of coherence.

\subsection{Managing Accession and Domestic Public Management Reform}

171. Managing the accession process and preparing for the transition to membership both have major consequences for the governments and administrations of candidate countries CEECs. Some of their direct implications have been considered in the previous two sections. But their impact is not confined to those areas of government that traditionally deal with foreign affairs and the external environment. The main conditions of membership include the ability to cope with the increasingly extensive demands that European integration places on national administrations. Because the EU is evolving as a pluralistic, multilevel system of governance, rather than a federal state, much of the administrative work, as well as a great deal of policy development, remains at the national (and subnational) level.

172. Each candidate country faces a steep learning curve as it comes to terms with the demands that EU membership makes and engages in the tasks of designing and developing appropriate organisational structures and administrative systems. While this may be regarded as an additional claim on administrations that are already overloaded by the tasks of economic transition and political reconstruction, it has two important potential advantages. First, since Europeanisation is in line with the objectives of other reforms, it gives administrations a specific direction that might otherwise be lacking. There are relatively concrete intermediate goals to work towards. Second, there is a structure of incentives and assistance to reinforce the process. It is up to each candidate government to work out its own strategy and develop its own supporting structure. Each must demonstrate that it is competent to handle the responsibilities of membership. But in the process all are in a position to draw on resources and assistance to aid in developing the requisite capacities.

173. Ministries and other public organisations concerned with a wide and widening range of policies have to take account of and adapt to norms established by the EU. Administrators in many specialist fields are expected to apply EU standards laid down in directives and regulations. A mass of detailed legislation has to be put into effect. This is not just a matter of implementing different policies through national systems. Increasingly, national officials have to learn to become reliable partners in multinational frameworks of governance which are being constructed to ensure the consistent implementation of EU policies across all Member States. Europeanisation, in this sense of integrated policy management, redefines the boundaries of administrative systems and prompts the redesign of existing relationships among their constituent organisations as well as the development of new ones. It becomes impossible to compartmentalise and separate responsibilities for managing internal and external affairs. In many instances the distinction between domestic and foreign policy becomes irrelevant. Policies traditionally thought of as purely national acquire a European dimension. Conversely, EU policies frequently depend on co-operation with and among national government to implement them. Competences (in the legal sense) of decision-making powers may be vested in European institutions, but the management capacities essential to make them work in practice are mostly located at the national and subnational levels.

174. This means that in the national day-to-day business of policy management, administrators and elected national politicians in governments are required to work within the framework of the larger EU system. This applies to both the formulation of policies, post-entry, and policy implementation in the pre-entry phase. There is an increasing volume of two-way traffic to deal with. Both officials and politicians occupying boundary roles have to become skilled at shifting backwards and forwards between acting in a national and a European context. 
175. Of course, some ministries will only have a partial and specific interest in some aspects of EU policies. Others are likely to become much more heavily involved. But the crucial point is that Europeanisation has a pervasive impact not just on policies but on administrative organisation and the way the business of government is conducted at the national level. What might have seemed a separate and remote concern of a foreign ministry or a trade ministry becomes an integral part of everyday life in ministries concerned with agriculture, industry, education, environment, customs, immigration, etc.

176. This is not to imply that national governments simply become the administrative agents for the EU. They are not just transmission belts for European policies. It is an important part of the duty and responsibility of national officials and politicians to represent national interests in the European arena. This requires thorough preparation and well-managed co-ordination within the national administration. In addition, it requires the development of links to economic and social organisations and interest groups outside government. Reliable governance is not just a task for government. If governments are to represent national economic interests on a highly technical subject, for example, it is important that industrial interests that could be affected are consulted. As the recent report about the effects of EU membership on Swedish administration commented, the views of affected social and economic interests should be sought as a matter of routine "When EC directives are implemented, for example, the Agency for Administrative Development considers it very important that the special-interest organisations involved be given the opportunity to submit their comments" (Statskontoret, 1996, page 33. See also page 35).

177. How much consultation and other forms of co-ordination are appropriate and feasible is open to debate. What is of fundamental importance is the widespread recognition of the need for effective management of interdependence within and between different units and levels of government, as well as with outside interests.

178. What implications does this have for programmes of public management reforms in CEECs? Three general observations may be made. First, what has just been said is entirely consistent with the main themes of the reinforced accession strategy included in Agenda 2000. This paper goes somewhat further in suggesting that there is a need to define public management reform programmes around national accession strategies. The goal of EU membership provides a key reference point for steering the transition process. National circumstances, priorities and needs should be taken into account in defining a capacity-building strategy.

179. Second, capacity-building poses different problems from those that have provided the focus for public management reforms in Western Europe and elsewhere over the last decade and more. Since the problems are different, so should the solutions be. The New Public Management prescriptions which have underpinned many (though by no means all) reforms are not the most appropriate for CEECs (Verheijen, 1996). They are mainly concerned with slimming down established systems rather than building new ones; they have a strong bias towards creating more specialised and differentiated organisations at the micro level. In the context of the pre-accession process, the most urgent needs are, not surprisingly perhaps, for better integration and co-ordination at the macro level. New Public Management reforms might only serve to increase fragmentation if they were given top priority.

180. This leads to the third observation. The reforms required in the pre-accession period are not simply reforms of low-level operational management. They are reforms of larger systems where governance and management interact. In addition to building new capacities, new institutional frameworks have to be designed and developed to ensure that they are used effectively. In this respect, the accession process is the management of change on a grand scale. 


\section{Conclusions}

181. The conclusion of the 1996/97 IGC, the agreement on the Treaty of Amsterdam, the presentation of Agenda 2000 and the announcement of the Reinforced Pre-Accession Strategy mark a decisive move to the next wave of EU enlargement. The aim of this paper has been to examine how CEECs can prepare to meet the challenges of accession. In contrast with the previous wave of enlargement, the central issue is the ability of the candidate countries to take on the responsibilities of membership, rather than their willingness to do so. The main priority is the development of a strategy for developing the capacities needed to negotiate accession and function as effective and reliable Members of the EU.

182. Given the size and complexity of the task, it is especially important to take a long-term view, going beyond the management of accession to include the management of membership. In effect, the Copenhagen criteria and the way they have been developed subsequently set this as a key condition of membership. This is an ambitious goal, but it makes sense from a national as well as an EU standpoint. The strategic objective for a candidate country is not simply membership of the EU, but creating the capacity to benefit from membership. For CEECs, meeting the demands of accession requires a quantum jump in their effectiveness. This cannot be achieved by shock therapy or a crash programme because it involves the management of change on a grand scale. Paradoxically, a quantum jump in effectiveness requires a gradual approach to capacity building so as not to cause overload.

183. A capacity development strategy comprising three components has been proposed. The first is the establishment of a system, along project management lines for managing the accession process. The second, overlapping the first, is the development of organisational capacities and interorganisational co-ordination to manage membership after accession. The third is the introduction of more general public management reforms to support Europeanisation.

184. Individually and together, these three components of a capacity-building strategy constitute a heavy workload. Achieving EU membership and benefiting from it subsequently require careful attention to each of them, even if this takes longer than national politicians and domestic public opinion would wish. Success depends on establishing a reputation as a reliable partner in the integration process. The whole process must be underpinned by a clear understanding of the conditions for successful reform and a deliberate effort to create and sustain them, as well as by conscious attention to the need to build capacity-building capacities.

185. In each candidate country, a demanding programme of institutional and management development is essential to transform governance capacities. Even in the most favourable of circumstances, it is bound to take a number of years. The fable of the hare and the tortoise is relevant; make haste slowly. 


\section{REFERENCES}

CHRISTENSEN, Tom. "Adapting to Processes of Europeanisation”, a study of the Norwegian Ministry of Foreign Affairs, ARENA Report, No. 2, June 1996.

DROR, Yehezkel. "Delta-type Senior Civil Service for the 21st Century", International Review of Administrative Sciences, Vol. 63/1, pp. 7-23, March 1995.

MAJONE, Giandomenico. Regulating Europe, Routledge, London, 1996.

METCALFE, Les. "International Policy Co-ordination and Public Management Reform", International Review of Administrative Sciences, Vol. 60, pp 271-290, Sage, London, 1994.

METCALFE, Les. "National Preparation for International Policy-Making - Capacities for Managing National Policy Coordination in the Context of European Integration", The Internationalisation of Policy Making - Institutional and Organisational Options to Integrate Domestic and International Aspects of Policy Making, SIGMA Papers: No. 6, OCDE/GD(96)45, pp. 29-55, Paris, 1996.

NICOLAIDES, Phedon and Sylvia RAJA BOEAN. A Guide to the Enlargement of the European Union: Determinants, Process, Timing, Negotiations (Revised Edition), European Institute of Public Administration, Maastricht, July 1997.

STATSKONTORET. The Effects of EU Membership on Swedish Government Administration, report prepared on the instructions of Swedish Government, Statskontoret, 1996:7A.

STEIN, Janice Gross. Getting to the Table: The Processes of International Pre-Negotiation, Johns Hopkins University Press, Baltimore and London, 1989.

VAN DEN BROEK, Hans. "The Waiting Room", Thesis - A Journal of Foreign Policy Issues, Vol. 1, No. 1, Spring 1997.

VERHEIJEN, Tony. "The Relevance of 'Western' Public Management Reforms for CEECs", Public Management Forum, Vol. II, No. 4, pp. 8-9, 1996. 
CCNM/SIGMA/PUMA(98)39

Chapter 3: Transposing Community Directives into the Legislation and Regulations of EU Member States

By Jean-Louis Quermonne ${ }^{6}$

6. Jean-Louis Quermonne is Professor of Political Science, University of Grenoble, France. 


\section{Introduction}

186. Problems with the transposition of Community directives into the legislation and regulations of EU Member States stem from the gradual merging of the political and legal systems of Member States, and perhaps of aspiring Members, with those of the European Union. Where the EU is concerned, the process mainly, if not exclusively, affects the first pillar known as the European Community, comprising the European Coal and Steel Community (ECSC), the European Economic Community (EEC) and the European Atomic Energy Community (EAEC), established respectively under the treaties of Paris (1951) and Rome (1957). If the third phase of Economic and Monetary Union comes into force on 1 January 1999, the Community will also include the European System of Central Banks (ESCB) and eventually, provided the Treaty of Amsterdam is signed and ratified, the third pillar of Community provisions.

187. One sign of this process is the interconnection between the legal institutions and legal orders of Member States and those of the European Union. Yet the links between the two are not the usual kind of systemic ties between sovereign States and international organisations, or between domestic and international legal orders. In fact, it matters little whether Member States have a dualistic or monistic legal tradition. The distinctive feature of Community law lies in the three main characteristics recognised by the case law of the Court of Justice of the European Communities (CJEC), namely direct and immediate applicability, supremacy over domestic law and uniformity of interpretation. The three rules apply to all Community law, be it primary (founding and accession treaties) or secondary (regulations, directives and decisions) $)^{7}$.

188. Since Community law penetrates directly into the legal system of each Member State, it does not have to be incorporated into domestic law in order to take effect there, although directives are a special case (see below).

189. Measures of general application in the form of secondary legislation need only be published in the Official Journal of the European Communities (OJEC) to become law on the effective date, or failing that, on the twentieth day following publication, while measures applying to individuals take effect as from notification. From that date onwards the institutions of Member States, and their nationals where appropriate, are bound to accord them legal force, subject to review by the national courts.

190. Directives, however, differ in a number of ways from other types of secondary legislation. Not surprisingly, they raise a series of problems at the interface between domestic and Community legal systems - problems to which Member States and European institutions have given various answers which the Luxembourg Court has attempted to harmonise in its case law.

191. This paper cannot, of course, give a comprehensive analysis of the practices used by all fifteen EU Member States to implement Community directives. It will simply endeavour to illustrate their variety by describing the most frequent and original ones. It will also take account of the specific situations prevailing in central and eastern European countries and will try to select examples of use to them. Before doing so, however, the special nature of Community directives has to be explained. The report will then go on to set out some ideas on the special problems of transposing directives into the legislation of new or applicant Member States.

7. QUERMONNE, Jean-Louis. Le système politique de l'Union européenne - Clefs, Ed. Montchrestien, 2nd edition, pp. 59-71, Paris, 1994. 
192. The paper will thus be divided into three sections. The first will highlight the singularity of directives for the legal systems that have to implement them. The second, forming the main body of the report, will address the various methods of implementation used in EU Member States. The third and last section will look at the situation in countries currently applying for membership and consider the changes that their accession may bring about to EU institutions, as a result of enlargement.

\section{Singularity of Directives at the Interface Between Community and Member State Legal Systems}

193. Like other normative acts of the Community institutions, directives share the characteristics of secondary Community legislation but have specific features of their own. This must be clearly understood.

194. Like regulations and decisions - and contrary to the rules habitually governing relations between international and domestic law - directives have a direct and immediate effect on the legal systems of Member States; they effectively take precedence over domestic law; and they are uniformly interpreted by the CJEC in cases referred to it by national courts.

195. These three features are not explicitly mentioned in the treaties but have gradually emerged from CJEC case law. In acknowledging a "new legal order of international law (...) the subjects of which comprise not only Member States but also their nationals" (Case 26/62 Van Gend en Loos, 5 February 1963), and in viewing integration as the ultimate aim of the Single Market, the Court has found that "the [EEC] Treaty has created its own legal system which (...) became an integral part of the legal systems of the Member States" (Case 6/64 Costa v. ENEL, 15 April 1964). The obligation to ensure that Community rules are fully applied has led the Court to recognise the precedence of Community law over the legal order in each Member State (Simmenthal, 9 March 1978).

196. So Community directives, like regulations and decisions, are an integral part of that legal order. They take effect in accordance with Article 191 of the EC Treaty, namely on the date of notification or, if the directive is published in the Official Journal, on the date specified in the directive or, failing that, on the twentieth day following publication; however, the final provisions of a directive may also postpone the date of entry into force ${ }^{8}$. Furthermore, in the absence of any hierarchy of norms based on some organic or formal test, a directive may be issued by the Council on the proposal of the European Commission in consultation, co-operation or co-decision with the European Parliament, or by the Commission alone. In the latter case, however, the directive is adopted pursuant to express provision in the treaties or, more generally, under rules laid down by the Council, which it has instructed the Commission to apply.

197. In all cases, Community directives are normative acts. Consequently they have nothing in common with the administrative directives found in France or Germany. They are however comparable to "recommendations" under the ECSC Treaty, which also have normative force.

198. While directives are similar to regulations and decisions, they nevertheless constitute a special type of Community legal instrument. This is recognised in Article 189, paragraph 3, of the EC Treaty which states that "a directive shall be binding, as to the result to be achieved, upon each Member State to which it is addressed, but shall leave to the national authorities the choice of form and methods."

8. SIMON, Denys. La directive europeénne - Connaissance du droit, Dalloz, Paris, 1997. 
199. The Community directive, as an extension to the EEC of the concept of recommendation first found in the ECSC Treaty, is the only instrument of European legislation involving a "two-stage or dual process implying by definition the successive intervention of Community and national authorities" . This raises two issues, namely the legal problem of transposing the directive and the political problem of implementing it, the latter being the main focus of this paper.

200. But the singularity of directives does not stop here. Although "binding" in the same way as regulations and decisions, they only bind those designated therein, namely the States or enterprises notified. However, since most directives are addressed to all Member States, it has become customary to publish them in the Official Journal, hence the CJEC description of them as measures "of general application" (22 February 1984, Kloppenburg, 70/83, Rec. 1075). Thus, the fact of being uniformly and simultaneously implemented makes them an indirect instrument of Community legislation. The use of directives to institute the internal market, pursuant to the 1986 Single European Act, placed them very high in the European legal order, and the concern of many Member States to clarify their provisions on implementation developed them still further.

201. Nevertheless directives, unlike regulations, have only limited legal force. They are binding on Member States only in terms of the result to be achieved, not as to "form and methods". This gives Member States considerable leeway by virtue of the subsidiarity principle. Compared with the authority given to the German Länder to implement federal legislation, the founding treaties left considerable discretion to EU Member States in implementing directives.

202. The logical outcome would have been to make a directive binding, in domestic legal terms, solely on Member States and territorial subdivisions responsible for implementation. But this interpretation, based partly on relations between domestic and international legal systems, might have jeopardised the supremacy and uniform application of Community law, and hence EU common policies, in the various Member States. Accordingly national courts and the CJEC have tended to agree in accepting extended availability of Community directives in some cases, notably to punish States which have not, or not properly, implemented them ${ }^{10}$. Moreover, the Treaty of Rome, as interpreted extensively by the Luxembourg Court, has sanctioned inertia on the part of Member States by introducing proceedings for non-compliance which can be set in motion by the Commission on its own initiative or by Member States. The Maastricht Treaty imposes lump-sum fines or penalty payments for failure to comply with the Court's judgments ${ }^{11}$.

203. Consequently, effective implementation and interpretation of directives are not left to the discretion of Member States. The methods they use must remain within a given framework. After a long period during which some Member States failed to implement directives (less through bad faith on the part of their governments than through inadequacy of their administration or slow parliamentary procedures), overall implementation rose from 89.3 per cent in December 1991 to a reasonable 93.6 per cent in March 1992.

9. SIMON, Denys. La directive européenne, op. cit, p. 23.

10. MANIN, Philippe. "L'invocabilité des directives: quelques interrogations", Revue Trimestrielle de Droit Europeén, p. 669, 1990.

11. BERTRAND, Christine. "La responsabilité des Etats Membres en cas de non transposition des directives communautaires", Revue du Droit Public, p. 1507, 5-1995. 
204. Furthermore, the threat contained in the new Article 171 of the EC Treaty, introduced by the Maastricht Treaty, is helping bring Member States tempted by non-compliance into line. Recently the Federal Republic of Germany, under threat of a fine after a second referral by the Commission to the Court of Justice, finally took steps to apply the water quality directive and avoided a penalty payment of ECU 264000 per day. Italy, under threat of a daily payment of ECU 123 900, also complied.

205. All these aspects of the legal regime governing directives will be examined in greater depth in the second section of this report, regarding sanctions that can be imposed on Member States to compel them to give effect to Community directives properly and before a specific deadline.

206. Briefly to conclude the first section of this report it is important to note that while the directive is an integral part of secondary Community law (Art. 189 EC, paragraph 1), it also has two distinguishing features. First, in domestic legal systems it has less direct effect, given the strict limitations on its availability to private individuals (legal writers contrast non-existent horizontal effect with limited vertical effect). Second, within that same legal system, the directive requires that Member States proceed with implementation before a deadline which it specifies and, although they are free to use the forms and methods established in their constitutions, this will be done subject to the dual supervision of the national courts and the Court of Justice in Luxemburg, which will hear cases referred to it by national courts, as well as proceedings for non-compliance.

207. To shed some light on the second of these two features, it is tempting to compare directives in the European legal order with the "outline laws" found in some countries. However, this would be more of an image than a comparison, since outline laws vary from one country to the next.

\section{Different Ways of Implementing Directives in the Main EU Member States}

208. Whatever the framework established by the case law of the Court of Justice of the European Communities, the methods used by Member States to apply Community directives have always differed in certain ways. This appears to anticipate Article F of the Maastricht Treaty, which stipulates that "The Union shall respect the national identities of its Member States, whose systems of government are founded on the principles of democracy", and also perhaps Article 3B of the EC Treaty and the principle of subsidiarity.

209. The resulting differences naturally relate - to quote Article $189 \mathrm{EC}$ again — to "the form and methods" which are left to the appreciation of each Member State's authorities, rather than to the "result to be achieved", which should be both effective and uniform. But form and methods raise enough problems to warrant comparison. This paper cannot undertake a comprehensive study of the practices used by all the Member States in the European Union ${ }^{12}$. It will, however, describe some significant examples, selected either because the Member State plays a major role in the EU or because it has found a particularly original way of giving effect to Community directives. The political regime variable will also be taken into account, although the great majority of countries do have parliamentary regimes which differ in their degree of rationalisation, some being semi-presidential (France in particular), and more importantly in terms of the traditions and culture of their political and parliamentary life and the structures of their legal systems.

12. For further details, see RIDEAU, Joël. Les Etats Membres de l'Union européenne - adaptations, mutations, résistances, LGD, Paris, 1997. 
210. In these various contexts, four types of national authority are regularly faced with the problem of implementing directives, namely governments as diplomatic authority, and their administrations; parliaments as legislative bodies; administrative and ordinary courts; and in some cases constitutional courts.

211. The fact that national governments not only help draft directives within the Council of Ministers but also implement them clearly puts them in the front line. But the efficiency of their administrations is also a decisive factor in determining how well this is done. For a long time the reason for most cases of non-compliance noted by the Commission and the Court of Justice was not so much bad faith on the part of government, as inability on the part of administrative departments to cope with the pace and technical aspects of implementation. There have also been cases where central government, in transferring responsibility to federal authorities or decentralised regions, has in fact complicated the process and delayed it still further. However, so far as the European Union and, more particularly, the Court of Justice are concerned, the Member State bears sole responsibility.

212. To overcome these difficulties, some governments have deemed it necessary to provide their administration with detailed instructions on how to apply Community law. France has used circulars (notably those of 22 September 1988 and 25 January 1990), and Spain the resolution of 10 September 1990.

213. Central governments have opted for one of two approaches to ensure co-ordination between all government departments so as to harmonise their relations with Brussels, via the permanent representatives based near the Community institutions. France and the United Kingdom, both centralised states, have set up interministerial units reporting to the head of government ${ }^{13}$. In France, it is called the Secrétariat général du Comité interministériel pour la coopération économique internationale (SGCI), and was set up when the OEEC was established in 1948 and used to further European integration ${ }^{14}$. In the United Kingdom, a European Secretariat has been included in the Cabinet Office and, although ministerial departments enjoy greater autonomy, it plays much the same role. In Italy too, the Decree of 10 March 1994 established a secretariat for community affairs reporting to the Prime Minister, but which works closely with the ministerial department set up for the same purpose.

214. In most of the other countries with no such unit, the real leaders are the ministry for foreign affairs and/or the ministry for the economy and finance, although the subject matter of each directive requires intervention by the relevant ministerial department with the technical knowledge required for implementation.

215. In federal states, the task of applying Community law may encroach on the exclusive powers of the federated states. In Germany, the Länder have even wider implementing powers. In such cases, provision is made for intervention by subdivisions, either directly or via the second chamber of parliament representing them, e.g. the Bundesrat in Germany and Austria. A more flexible system is found in Spain, for the benefit of the Autonomous Communities. If the Scottish devolution bill becomes law, specific measures will bring Scotland into the Community decision-making process.

13. QUERMONNE, Jean-Louis. L'appareil administratif de l'Etat, p. 37 onwards, Collection Points, Seuil, Paris, 1991.

14. LEQUESNE, Christian. Paris-Bruxelles - comment se fait la politique européenne de la France, Presses de Sciences-Pô., Paris, 1993. 
216. Conversely, EU membership has not yet made much impact on the structure of Member State governments. In France, and to a lesser extent Finland, it has of course enhanced the status of the President, who now has a seat on the European Council. In other countries, the head of government has benefited. But resistance from foreign affairs ministers has so far managed to curb the role of ministers for European affairs - if any - who are usually a minister of state, a ministerial delegate or a secretary of state. Only the Italian mnister has (to the author's knowledge) been given something a real department. However, the fact that ministers for European affairs often sit on the Council when it meets to regulate the internal market provides them with expertise that they subsequently tend to use for political control over the implementation of numerous directives.

217. Their role would of course take on more importance if, as has been suggested, the ministers of foreign affairs became ministers residing in Brussels in order to sit on the Committee of Permanent Representatives (COREPER). But that is not yet the case.

218. By and large, regardless of how roles are distributed within national governments, it is primarily up to governments to ensure that implementation proceeds correctly. Whether this is done through legislation or regulations, the initiative almost always lies with the government. Hence the need for governments to find an efficient way of synchronising and monitoring the dual process of transposition into laws and regulations.

219. Parliaments play a wide range of roles in applying Community directives, depending on the country. This is because the process raises two thorny political and constitutional problems, one legal and the other political.

220. The legal problem stems mainly from the way laws and regulations are linked in individual countries.

221. In France, the Constitution of the Vth Republic strictly limits the domain of legislation to the subjects listed under Article 34, the others falling automatically into the regulatory domain as specified under Article 37. This innovation, written into the Constitution in 1958 to reduce the number of laws being passed, has had the "perverse" effect of limiting Parliament's role in the transposition of Community directives. In 1992, for instance, it appeared that of 1000 instruments on transposition, only 75 were of a legislative nature ${ }^{15}$. Paradoxically, deciding which directives require mandatory intervention by Parliament, in response to bills presented by government, is a task that falls - at the government's request - to the Conseil d'Etat, by virtue of a simple circular from the Prime Minister dated 25 January 1990. In any case, when parliamentarians are required to play a role, they often complain that directives are so detailed that all they can do is "rubber-stamp" them.

222. In Denmark, on the other hand, the Folketing (Parliament), jealously guarding its prerogatives, strictly limits the authority of the government to pass regulations, and only exceptionally enacts legislation delegating to government the task of implementing Community directives. Here more than anywhere else, parliamentary sovereignty contrasts with a regulatory domain that is wide-ranging and autonomous. Consequently, Parliament either exercises its own prerogatives or delegates them to government on an ad hoc basis but with severe a posteriori review.

223. In Spain, on the other hand, although the Cortes Generales are competent for all matters on which Parliament has already legislated, Article 82 of the Constitution authorises them, with the exception

15. Rapport public, Conseil d'Etat, 1992. 
of certain reserved areas, to delegate to the government power to adopt provisions with the force of law in specified fields, including implementation of Community directives. In Greece, implementation results in practically all cases from enabling legislation adopted by the Greek Parliament. Even in the United Kingdom, despite the prestige of the Westminster Parliament, the European Community Act of 1972 "provides that application of Community law, even when it is intended to replace a provision of domestic law or an Act of Parliament, is to be by Order in Council or by regulations rather than by an Act of Parliament as such" ${ }^{\prime 16}$.

224. An original practice has prevailed in Italy since 1989 with the La Pergola Act. Having first left application of Community directives to the government on a case-by-case basis by means of a mass of legislation passed well after the event, the Italian Parliament then rationalised the legislative and administrative workings of the State as follows: every year before 31 January the government has to prepare a bill setting out "provisions for performance of obligations deriving from Italy's membership of the European Communities". This annual "Community Act" includes, in particular, all provisions necessary for implementation of directives, either in the form of legislation as such, or by delegation of government powers. An annex to this Act sets out a list of directives which the government wishes to implement via regulation, which must happen within four months of entry into force of the Act.

225. Practice followed since 1990 in Italy undoubtedly shows that delegated legislation remains the principal means of implementation of directives ${ }^{17}$. Annual review by Parliament has at least been stepped up. Regions with special status have also been given direct power to implement directives in areas within their responsibility, whereas ordinary regions must await the annual Community Act before doing so.

226. In federal-type states, the subdivisions of the State have of course a more important role to play. This is so in Austria and Belgium, but more particularly in Germany. The new Article 23 of the Basic Law, following the constitutional revision of 1992, gives the Länder individually, or via the Bundesrat, real powers in regard to directives whose implementation encroaches on their constitutionally recognised competence. This tendency has moreover become more marked as time goes by. It has recently been seen that the susceptibility of the Länder regarding their prerogatives goes far to explain the reservations of Chancellor Kohl at the Amsterdam Treaty negotiations, regarding extension of qualified majority voting in the Council of the European Union.

227. The Länder, responsible in Germany for implementing federal legislation, have thus also insisted on being more closely associated with the preparation of Community directives from the outset. This is, moreover, the other aspect of the problem, namely participation of national parliaments themselves in European legislation of a more political nature.

228. Since this only indirectly affects implementation of directives, it will only be briefly looked at here. But insofar as national parliaments have gradually become aware both of their limited room for manoeuvre in regard to implementation of directives, and of the extension of Community legislation to ever broader fields, it has in itself become of increased political importance.

229. It is true that by reason of their diplomatic prerogatives national governments have been able to acquire, by exercising it within the Council of the Union and COREPER in Brussels, much of the

16. DUTHEUL DE LA ROCHERE, Jacqueline and Malcom JARVIS in RIDEAU, Joël, Les Etats Membres de l'Union européenne, op. cit., p. 409.

17. ASTENGO, François, id., p. 328. 
legislative power that has so far eluded the European Parliament. This violation of the separation of powers is increasingly seen as a "democratic deficit". The attempt by governments to make the European Commission the "scapegoat" for this process has become less and less convincing.

230. This being so, not to mention the request by the French Parliament to its partners and to the 1997 Intergovernmental Conference for re-establishment of a second chamber of the European Parliament made up (as was the case prior to 1979) of members of national parliaments, or failing this, for creation of an interparliamentary body to review application of the subsidiarity principle, national parliaments have on numerous occasions shown their determination to resist loss of their authority. In most cases, domestic constitutional practices have been extended over time. Recently, however, there have also been moves towards interparliamentary co-operation.

231. The Danish Folketing has gone furthest vis-à-vis its government in this respect. The latter must forward to the Parliament's European committee all proposals for regulations, directives and decisions presented by the European Commission to the Council of the Union. The Danish minister has to appear before this committee which instructs him what attitude to adopt at the Council in Brussels. If he has to take another line for the purposes of negotiation, he must reappear before the committee before any final decision is reached.

232. Naturally, were the 15 national parliaments of the European Union all to adopt the same attitude, the already complex Community decision-making process would inevitably grind to a standstill. Other parliaments have therefore devised a more flexible form of review described as "subject to consideration by parliament". This domestic procedure simply obliges governments to inform their national parliaments in real time, via the appropriate committees or delegations, and to reserve their position in Brussels pending consultations or until a reasonable time has elapsed. However, the political responsibility of governments with parliamentary systems means that ministers' hands are not tied, and they are still free to negotiate. Their room for manoeuvre is thus safeguarded.

233. Systems of this kind now operate in most Member countries of the Union, with varying degrees of flexibility and depending on the number of chambers of parliament. They are to be found in particular in the United Kingdom, Germany, the Netherlands and Spain. In France, the procedure has been embodied in Article 88(4) of the Constitution, following the constitutional revision of 1992 which gave parliamentary assemblies the right to adopt resolutions setting out their attitudes regarding draft Community regulations or directives with legislative implications.

234. In 1997, general use of this practice led the Intergovernmental Conference to annex to the draft Amsterdam Treaty a protocol on the role of national parliaments in the European Union designed to recognise the practice. Apart from institutionalising the Conference of Bodies Specialising in Community Affairs (COSAC) set up in Paris on 16 and 17 November 1989, the protocol provides for national parliaments to be informed in the three following ways:

- all consultative documents of the Commission (green books, white books and communications) are to be forwarded rapidly to the national parliaments of Member States;

- legislative proposals by the Commission, defined by the Council in accordance with Article 151 of the Treaty establishing the European Community, are to be communicated in sufficient time for the government of each Member State to ensure that they are forwarded in a proper fashion to national parliaments;

- a period of six weeks is to elapse from the time when a legislative proposal or proposed measure for adoption under Title VI of the European Union Treaty is made available by the 
Commission to the European Parliament and the Council in all languages and the date on which it is included on the agenda of the Council for decision, either with a view to adoption of an instrument, or to adoption of a common position in accordance with Article 189B or $189 \mathrm{C}$, with possible exceptions in urgent cases the reasons for which are to be set out in the instrument or common position.

235. Before implementing a directive or delegating that function to their governments, national parliaments ought therefore henceforth to be properly informed of prior negotiations and deliberations. Without necessarily making them actors in the procedures, such measures should allow them to exercise their specific responsibilities under better conditions.

236. National courts are also called upon to intervene in the implementation of Community directives. Such intervention, which enables them to condemn shortcomings or irregularities of the other powers does not materially differ from the supervision they exercise over application of European law by Member States as a whole ${ }^{18}$.

237. The Court of Justice in Luxembourg pointed out moreover in a decision of 10 April 1984 (Von Colson v. Kaman, 14/83, p. 1891) that "the Member States' obligation arising from a directive to achieve the result envisaged by the directive and their duty under Article 5 of the Treaty to take all appropriate measures, whether general or particular, to ensure the fulfilment of that obligation, is binding on all the authorities of Member States including, for matters within their jurisdiction, the courts."

238. In addition, since Community law must be interpreted in a uniform manner, national courts are invited, where the wording is not clear, to refer the directive to the CJEC for interpretation, and this has led the Luxembourg Court gradually to set a framework for national courts. Lastly, the comparative frequency of actions for infringements (1 043 cases from 1 January 1973 to 1 January 1994) has also enabled the Court to clarify the scope of major Community directives on a case-by-case basis.

239. There is not enough space here to examine the respective roles of national courts and the CJEC. Let it simply be said that the latter (CJEC) ensures compliance by the former (national courts) with the three principles defined by Denys Simon as follows ${ }^{19}$ :

- access to legal review, whereby "remedies under national procedural law shall not be less favourable in cases of application of Community law than for equivalent proceedings under domestic law";

- provisional protection of litigants whose rights have been violated by national authorities;

- ex officio application of Community law by national courts, even when not invoked by the parties themselves.

240. But in addition to these procedural provisions the question that most frequently arises relates to the degree of direct effect of directives in the domestic legal order.

241. Admittedly, as pointed out in the first part of this report, directives, like regulations and decisions, are an integral part of secondary Community legislation. As such, they share the same characteristics. But, as already emphasised, they are special in that their direct effect may vary, since

18. SIMON, Denys, op. cit., p. 80 et seq.

19. SIMON, Denys, op. cit., p. 80 et seq. 
domestic measures are required to implement them. Logically, therefore, only these implementing measures should be invocable.

242. Such a solution will presumably always be adopted in disputes between private individuals, owing to the "horizontal" character (CJEC, 14 July 1994, Faccini Dori. C-91-92, Vol. I-3349) of the litigation. On the other hand, in "vertical" litigation between a private individual and a Member State an innovative line of CJEC decisions accepted, subject to certain conditions, that there could be full direct effect. The conditions were that the provisions of the directive concerned be clear, unconditional and legally perfect. However, recrimination arising from the Ratti (CJEC 5 April 1979, 148/78, p. 1629) and Becker (19 January 1982, 8/81, p. 53) decisions, condemning Member States which had failed to implement directives, led the Luxembourg Court to adopt a stance based more on the principle of the precedence of Community law in order to sanction states which failed to meet their obligations.

243. This more cautious approach, combined with resistance by national courts, of which the French Conseil d'Etat's Cohn Bendit decision remains the most striking example (CJEC 22 December 1978, Dalloz, 1979, p. 155), now allows national courts and the CJEC itself to sanction Member States for their inertia or erratic behaviour by invoking their civil liability. As regards national courts, we could refer, this time in a positive sense, to the example of the French Conseil d'Etat in the Rothmans, Philip Morris and Arizona Tobacco case (28 February 1992, ADJA 1992, p. 210). Regarding the Luxembourg Court, the decision of principle, which seems likely to prevail, is to be found in the Francovich and Bonifaci case (19 November 1991 C-6/90 and C-9/909, I-5357).

244. Mention has been made at the end of the first part of this report of the impact of the new wording established by the Maastricht Treaty for Article 171 EC which punishes failure to comply with decisions of the Luxembourg Court of Justice by requiring the defaulting state to pay a lump sum or penalty.

245. In addition, it should be remembered that no Member State can avoid its obligations as a result of its internal structures, whether they involve separation of the executive and legislative powers or the autonomy of decentralised or federated bodies (CJEC, 22 February 1979, Commission v. Italy, 163/78, p. 771).

246. The problem remains of whether direct and immediate applicability and the precedence of Community law over domestic law are binding on national courts when considering Community directives which extend to the provisions of constitutional law. The answer to this question is still far from uniform as regards secondary Community legislation.

247. On the one hand, some CJEC decisions do seem to imply precedence of Community law as a whole over the legal orders of Member countries, including their constitutions. This was at any rate the interpretation given in the Costa v. ENEL and Simmenthal decisions, and would imply that in the ultimate analysis the case law of the Court views the Community legal order, separate from international law, as generating a "virtual" European federal state.

248. On the other hand, the positions of national courts and, when they have the opportunity, constitutional courts, seem much more qualified. The French Constitutional Council and Council of State see the precedence of Community law as based on domestic legislation rather than on some autonomous Community legal order embodied in the national legal order, i.e. it results from Article 55 of the Constitution of the Fifth Republic which grants "properly ratified or approved treaties or agreements ... as from publication, higher authority than that of domestic laws subject, for each agreement or treaty, to 
implementation by the other party". As regards original Community law, its non-conformity with the French Constitution requires, under Article 54, a revision of the Constitution prior to any ratification ${ }^{20}$.

249. The case law of the German and Italian constitutional courts appears less clear-cut. However, in the absence of any European federal state meeting the requirements of the rule of law and democracy, they refuse to accept that European law has any precedence over national constitutional provisions. As regards Germany, the decision of the Karlsrühe Court regarding compatibility of the Maastricht Treaty with the Basic Law takes a somewhat restrictive view of the principle of precedence of the Community legal $\operatorname{order}^{21}$. The influence of the Länder, anxious to retain their autonomy, has also led the Federal Republic to adopt a cautious stance on this point.

250. This marks the limit to the precedence of Community law as it has emerged from the case law of the European Court. In a climate of Euro-scepticism certain politicians have sought to reverse the trend so as to enable constitutional courts to review conformity of European directives with national constitutions whenever cases are brought claiming that implementing measures are unconstitutional. This is in particular the case in France following the proposed constitutional law submitted by the former chairman of the National Assembly's legislative committee, the lawyer Pierre Mazeaud.

251. The continuing ambiguity regarding the legal and political nature of the Community and the European Union is not helping to clarify the matter. Only the development of these "non-identified political objects" into a federal state with its own comprehensive legal order, would establish a clear and certain hierarchy among national and Community legal orders.

252. In the meantime, as Joël Rideau has written, "there is no constitution carrying Monet's thinking to its logical consequence". Precedence of Community law over national law ends in a kind of no man's land between legislation and constitution. Again as Louis Favoreu has written, "ultimately it is better to see the problem of the hierarchy of constitutional and international law as a non-existent one, even in the case of France where the Article 54 procedure does nevertheless seem to imply some hierarchy. Two systems of law exist side by side without interpenetration, at least in constitutional terms" ${ }^{, 22}$.

\section{Problems Facing Candidate Countries and the European Union on Enlargement of the Community in Regard to Directives}

253. In 1992 there were 1675 implemented directives, and 22454 Community regulations ${ }^{23}$. These figures alone show the implementation and integration efforts required of new Member countries of the Union in the first years of the 21 st Century! Such states are faced with two problems: that of introducing Community law adopted after their accession; but more important that of assimilating the "stock" of

20. CHAGNOLLAUD, Dominique and Jean-Louis QUERMONNE. Le gouvernement de la France sous la Ve République, p. 465 et seq. and p. 714 et seq., new edition, Fayard, Paris, 1996.

21. GERKRATH, Jörg. "La critique de la légitimité démocratique de l'Union européenne selon la Cour constitutionnelle fédérale de Karlsrühe", in DUPRAT, Gérard, L'Union européenne, droit, politique, démocratie, politique aujourd'hui, p. 209 et seq., PUF, Paris, 1996.

22. FAVREU, Louis and Loïc PHILIP. Les grandes décisions du conseil constitutionnel, p. 803, 8th edition, Sirey, Paris, 1995.

23. By 1996 the number of directives in force had risen to 2084 . 
directives (and ECSC recommendations) accumulated since the Treaty of Rome of 1957 and the Treaty of Paris of 1951.

254. The urgency of the second problem will inevitably raise difficulties not encountered by the founder countries nor by those which joined in the 1970s. The new Members from Central and Eastern Europe will therefore turn primarily to Spain and Portugal, and to Austria, Finland and Sweden for lessons and advice on how to proceed.

255. But the scale of the obstacles to be overcome this time seems disproportionate to that of previous occasions. There are therefore bound to be repercussions for the institutions and structure of the Union itself, imposing more flexibility in regard to the new Members. This is the other aspect of the problem we shall touch on.

256. Hitherto new Member countries and the Community institutions have attempted to deal with the problem of absorbing the mass of regulations and directives in force in a number of ways. But they all had to comply with the sacrosanct principle of respect for the acquis communautaire, clearly established following the long negotiations preceding the United Kingdom's entry to the Common Market. Today the principle seems beyond challenge and was reaffirmed in 1994 in Article 2 of the Act concerning the conditions of accession of the Republic of Austria, the Republic of Finland and the Kingdom of Sweden and adjustments to treaties on which the European Union was founded. That Article states that from accession the provisions of the original treaties and acts adopted prior to accession by the (Community) institutions are binding on the new Member States and applicable in those states in accordance with such treaties and the present $\mathrm{Act}^{24}$. When the European Council in Edinburgh granted Denmark, following a negative referendum result, a number of exemptions from the Maastricht Treaty, it was clearly specified that they did not in any case set a precedent for new Member countries.

257. However, since Community law cannot be introduced all at once, various approaches have been tried out by countries which have joined the Communities and the Union since the end of the 1980s. We shall look briefly at a number of them.

258. The first example is that of Spain, whose government as from July 1978 began to bring its legislation into line with Community law. From that time, the Council of Ministers encouraged the different ministries to "examine Community regulations in force to avoid as far as possible any conflict between Spanish regulations and Community law"25. This preliminary work was followed after accession on 1 January 1986 by recourse to delegated legislation to speed up actual implementation of directives.

259. A second precedent, of broader scope, results from the initiative of Jacques Delors to associate more closely with the European Community, without leading to full membership, the countries of the European Free Trade Association (EFTA). This endeavour, commenced in 1986, was to lead to creation of the European Economic Area (EEA), the basis for which was established by the Porto Treaty, which took effect on 1 January 1992 after being rejected by referendum in Switzerland. This treaty was intended, with the exclusion of agriculture, to set up a free trade zone between the EEC and the EFTA countries, implying integration in their legal orders of a large part of Community legislation. In fact, except as regards Norway, Iceland and Lichtenstein, the EEA served as a pre-membership arrangement for the other

\footnotetext{
24. OJEC, 29 August 1994.
}

25. BURGOGUE LARSON, Laurence in RIDEAU, Joël, Les Etats de l'Union européenne, op. cit, p. 171. 
EFTA countries which subsequently became full Members: Austria, Finland and Sweden. In any event, it considerably speeded up the process.

260. A third approach, this time related directly to the countries of Central and Eastern Europe, took the form of the European Association Agreements concluded, following the fall of the Berlin wall and the break-up of the Soviet Union, between the European Communities and a number of countries under Article 238 EC. These agreements, preceded by the Phare Programme, were to constitute the first step in a pre-membership process. Concluded for the first time on 16 December 1991 with Poland, Hungary and Czechoslovakia, they were extended to Romania and Bulgaria, and after the break-up of Czechoslovakia, to the Czech Republic and Slovakia, and finally in 1995 to the Baltic States and Slovenia. These agreements provide for creation of a free trade area for a period of ten years after their entry into force subject to certain limitations, and state that the ultimate objective for the signatory countries is membership of the European Community, without formal commitment by the latter. However, since the European Council in Copenhagen in June 1993, the European Union has gradually come to accept the principle of such membership and numerous pre-membership measures have been adopted. Following the Opinion of the Commission, the European Council in Luxembourg in December 1997 gave the go ahead for the negotiations.

261. However, if membership is not to be delayed for several years, or in some cases for one or two decades, it would be an illusion to think that pre-accession measures will themselves apply the mass of directives in force in all the countries concerned. From unofficial sources in Brussels, it appears that as at 1 January 1997 the most advanced country had absorbed no more than 15 per cent of existing Community legislation. There is therefore still a long way to go. This being so, a fourth approach has to be used as on previous occasions, i.e. inclusion in future accession treaties of provisions according new Member States transitional measures to spread application of Community law, and of directives in particular, over time.

262. It remains that such a policy, if it is to be agreed to by the European Commission and the Council of the Union, could not give the countries of Central and Eastern Europe an unlimited period of grace. Although "time has to do its work," it would be harmful, not only to the cohesion of the Union, but to the new Member States themselves, to allow them "extra time". Differences in the pace of integration, acceptable in a multi-speed Europe, would quickly become unacceptable if it led to Europe "à la carte". In this connection, it was stipulated that exemptions granted the United Kingdom and Denmark at the time of the Maastricht Treaty did not constitute a precedent. At the Amsterdam Summit, the British Prime Minister, Tony Blair, thus recently abandoned the exception regarding the social chapter. Of course the single currency remains outstanding.

263. It is clear that the transition from Europe of 15 countries to one of 25 or even 30 could, if care is not taken, lead to a loss of coherence and cohesion for the Union with the risk of ultimate dissolution. Offering candidate countries membership of a dislocated Union could well amount to "misrepresentation", including and perhaps above all in relation to foreign security.

264. Consequently, full respect for the acquis communautaire, even though a flexible timetable is necessary, is not negotiable in the long term. The problem of implementation of Community directives has to be considered against this background and this requirement. Admittedly, such a constraint might be seen as a dictat. But, once in the Union, the new Member States will have the same right as the others to change existing legislation. Moreover, in a Union with a large number of Member States, making unanimous decisions practically impossible, there has to be a move towards generalised introduction of majority voting in the Council. This is precisely what the European Council in Amsterdam (June 1997) failed to do, by not including in the new draft Treaty adequate measures to offset the future enlargement of the Union by appropriate changes to its mode of governance. 
265. Flexibility is indeed essential to enable the countries of Central and Eastern Europe to join the European Union fairly rapidly. But if the fact that different countries are at different stages is not to end by each country taking a different course, structural arrangements have to be strengthened and some form of government emerge at European level. If this is not done, both economic and monetary union and common foreign and security policy will become an illusion. Those countries which wish to go further on the road towards integration would use the new provisions in the draft Amsterdam Treaty to reinforce co-operation among themselves, leading inevitably to a Union with an inner and outer circle: the inner one consisting of countries determined to establish a federation capable of becoming an economic and political power as perceived by Jacques Delors ${ }^{26}$, and an outer circle of the others exposed to domination by the former and likely to be seen as second class Members.

266. This twin challenge faces both the European Union and its Member States on the one hand, and candidates for accession, not to mention those still hesitant like Norway or Switzerland, on the other. Implementation of Community directives is undoubtedly but one aspect of the problem. But there is no doubt that it forms part of this institutional and geopolitical context.

26. DELORS, Jacques. Combats pour l'Europe, Economica, Paris, 1996; CROISAT, Maurice and Jean-Louis QUERMONNE, L'Europe et le fédéralisme, Clefs, Ed. Montclustière, Paris, 1996. 
PART II: MEMBERSHIP NEGOTIATIONS AND PREPARATION FOR ACCESSION

Chapter 4: Preparation of EU and CEEC Institutions for the Accession Negotiations

By Alan Mayhew ${ }^{27}$

27. Alan Mayhew is Professor at the University of Leuven, Belgium, and former acting head of the EU Phare Programme. 


\section{Background}

267. Preparing the accession negotiations between the European Union (EU) and the associated countries of Central and Eastern Europe (CEECs) that have applied for membership will have major institutional consequences for both. The objective of this paper is to explore the roles of the institutions in the preparation and running of the negotiations on both sides, the roles of institutions in third parties at bilateral or multilateral level, and the institutional changes which negotiations will imply for all parties.

268. The background to the negotiations is well known. Ten countries in Central and Eastern Europe have negotiated association agreements with the EU, all of them have applied for accession to the Union and all are preparing for their entry. On the Union side, accession of the CEECs was agreed in principle at the Copenhagen European Council in June 1993 subject to the following criteria:

- the existence of democracy, the rule of law, respect for human rights and for minority rights;

- the existence of a functioning market economy;

- the capacity to resist competitive pressures from the Union;

- the capacity to accept the responsibilities of membership (the ability to take over Community regulation and policies, including eventually economic and monetary union - generally known as the Community "acquis");

- the capacity of the Union to absorb new Members without losing efficiency or reducing the level of integration.

269. The Essen European Council in December 1994 determined a pre-accession strategy to help the associated countries prepare for membership, including the White Paper on the internal market, which was approved in June 1995. The Madrid Council in December 1995 asked the Commission to prepare Opinions on the membership applications and to report (after the conclusion of the Inter-Governmental Conference) on the impact of enlargement on Community policies and on the budget. In response, the Commission presented its "Agenda 2000" proposals to the Council and the European Parliament in mid-July 1997. The European Council meeting in Luxembourg in December 1997 took the final decision on the opening of negotiations.

\section{Agenda 2000}

270. The first thing to note about the Agenda 2000 documents is that they are proposals not decisions. The Council will decide in December and could radically change these proposals.

271. Agenda 2000 consists of seven parts:

- a first outline of the European Union's budget (the New Financial Framework) for the period 2000-2006 in the light of enlargement;

- an analysis of the Common Agricultural Policy after enlargement and proposals to reform it;

- an analysis of the necessary reforms in the Community's structural funds;

- an assessment of enlargement's impact on other European Union policy areas;

- the Opinions on the applications for membership of 10 associated countries;

- an overall assessment of which countries should be invited to negotiate with the EU; 
- a reinforced pre-accession strategy.

272. The discussions in autumn 1997 in the Council of Ministers concentrated on the last two points, in order to prepare the decision of the European Council on the opening of negotiations. The reform of Union policies is so complex that it is unlikely that agreement will be reached between the 15 Member States before 1999. This will render the negotiations extremely complex.

\section{The Scenario for the Negotiations}

273. No decisions have been taken on the way in which the negotiations will be run; these decisions, which will effectively be taken by the Council in Brussels, are likely to be decided on only after the Council has resolved the question of the scope of the negotiations.

274. There is no guarantee that the negotiations will be run in the same way as previous enlargement negotiations; nevertheless certain features are common to all negotiations. After a ceremonial official opening, the accession negotiation conferences, one for each applicant, will establish their work programmes. The first step will probably be a consideration of the whole of the acquis, divided into chapters, to determine where the problems in the negotiations are likely to occur. This process may well take place between the Commission and all the negotiating CEECs together. It will take longer than it did in the EFTA enlargement, where most of the internal market acquis had already been agreed in the context of the European Economic Area agreement. It will also be longer because the process of learning about each other will take more time than with the EFTA countries.

275. At the latest by the end of this first reading of the acquis, the CEECs must know exactly which parts of the acquis they can accept and which parts are problematic for them. The CEECs can ask for clarification, written or oral, during this exploratory stage, in order to enable them to decide whether the acquis will or will not cause problems. Normally at the end of the first stage of the negotiations, those parts of the acquis which pose no problems will be closed and will not be revisited during the negotiation.

276. For the remaining areas, the Union will expect to receive position papers laying out clearly what the nature of the problem is and how the applicant proposes to solve it. It will be vital for the CEECs to have clear position papers early in the negotiations. The Union side will then prepare a common position to present as its offer on each of the problem areas (the EU may not agree to move from its initial position of course). Often it will be more difficult to get agreement on a common position between the 15 than it will be to get agreement on it with the CEECs.

277. The timing of the various stages is difficult to predict. Normally this second stage, with the handing over of position papers could be reached in the second half of 1998; this will however depend on the willingness of both the EU and the CEECs to proceed quickly. The Union produced a timetable for the negotiations with the EFTA countries, including a date for the actual accession to take place, relatively early on. It may be less willing to do this in the current negotiation, because of its complexity and the larger number of countries involved. It would however be in many ways an advantage to have a timetable fixed beforehand, even if it were only indicative.

\section{The Role of Institutional Actors in the EU}

278. On the EU side, three institutions will be primarily involved in the process of accession: the Council of Ministers, the European Parliament and the European Commission. Other institutions such as 
the Economic and Social Committee or the Committee of the Regions will give opinions, but these will not be binding, though they will be taken into consideration.

\subsection{The Council of Ministers}

279. The Council of Ministers will decide on the opening of the negotiations, preside the negotiations and take all the key decisions in the enlargement process. On the EU side, it is therefore the decisive institution in the enlargement process.

280. The Presidency of the Council will preside the negotiations. As the Council Presidency changes every six months, it is likely that the whole process up to accession will be in the hands of twelve or more Member States. Each of the Presidencies will have its own priorities and its own position on enlargement. This means that there will be periods of more and less rapid progress, though the negotiations will continuously advance towards a conclusion. The changes in Presidency emphasise the need for the CEECs to maintain good bilateral contacts with the Member States.

281. The Council Secretariat, under the authority of the Presidency, is in charge of the arrangements for both the discussion of the Agenda 2000 package and for the negotiations themselves. The Council Secretariat is likely to play a more decisive role in the coming enlargement negotiations than in the past. Its power and influence has been growing over the last few years and indeed in the Amsterdam Treaty, the Secretary General received new powers in the area of the Common Foreign and Security Policy of the Union. The Council Secretariat will play an important role in the organisation and timing of all meetings in the negotiation process, in the drafting of minutes of meetings and of compromises and possible solutions to problems in the negotiations. It is vital for there to be a good working relationship between the Council Secretariat and members of the CEEC negotiating teams.

282. The Council has already established the procedures to be used to deal with Agenda 2000 and to prepare the December Luxembourg Council. The organisation of work in the Council is always essentially the same though different names will be given to the committees when dealing with enlargement or with the negotiations.

283. The essential work is done in the working groups of the Council, consisting of representatives of the Member States, the Council Secretariat and the Commission. The representatives of the Member States are usually diplomats from the Permanent Representations in Brussels, but they are joined on special topics by colleagues from the "Capitals". These groups agree the vast majority of points on any subject, leaving only those points on which no agreement is possible for higher-level groups.

284. These problem points are sent to the Committee of Permanent Representatives (COREPER). COREPER is certainly the key committee in the Council, taking many of the most important decisions and leaving as little as possible for decision by Ministers. The atmosphere in COREPER is usually very collegiate and good-humoured, although the bargaining is often very hard. The Permanent Representatives are regarded as amongst the most powerful people in Brussels.

285. What cannot be decided in COREPER goes to Ministers meeting in the different specialist Councils. The General Affairs Council is undoubtedly the most powerful. Its members are the foreign ministers of the Member States and they set, in a certain way, the agenda for the Council. The most intractable problems frequently end up at the European Council, attended by the heads of state and government, and held at least once in each Presidency. 
286. Ad hoc groups can of course be formed to deal with specific tasks. These are agreed by the Presidency. A "high-level group" dealt with the Copenhagen criteria for accession discussion under Danish Presidency in 1993 and a "Groupe des Amis" will examine the financial and policy adjustment aspects of "Agenda 2000'. These are essentially ad hoc high level working groups, reporting as normal working groups to COREPER.

287. This mechanism for resolving problems between the Member States is most important for the CEECs to understand. Many of the most difficult problems in the negotiations will be between the Member States themselves, in the search for common positions to put to the applicant countries in negotiations.

288. The essential work to prepare for the European Council of Luxembourg in December 1997 was done by the Working Group on Enlargement. This group concentrated on the Commission Opinions on the different countries, the countries with which to open negotiations and the pre-accession strategy. It reported to COREPER II which will prepare the work of the General Affairs Council.

289. The results of the first study of the Commission papers were considered by an informal meeting of foreign affairs ministers at the end of October 1997. The General Affairs Council then met in early November to consider a draft report to the European Council. The report was finalised in early December and deliberated on by the European Council in Luxembourg on 12-13 December 1997.

290. While the procedures in Council for taking decisions on the opening of negotiations on enlargement are relatively clear, those to be adopted for the negotiations themselves are not. No serious consideration has been given to this question, but it must be assumed that similar procedures will be adopted as in previous negotiations.

291. The Council structures on the Union side outlined above will remain the basis for Union decisions. Following previous negotiations, accession negotiation conferences will be set up with each of the CEECs admitted to the negotiations. They will meet occasionally at ministerial level (opening of negotiations or when certain chapters of the negotiations are being closed), but usually for working sessions at deputy level. There will of course be many ad hoc discussions in Council to tackle specific problems.

292. For the CEECs, it is important to assess the degree of independence of the national officials working in Brussels and their role in relation to the ministries in the capitals. The diplomats in the working groups usually work on the basis of briefings and positions received from the capitals. In the course of meetings, however, they may make suggestions themselves subject to confirmation from their capitals. Disputes often arise amongst civil servants in the capitals and those in Brussels, because they are looking at problems from different perspectives. Those in Brussels often have a better view of the possibility of getting their country's interests partially respected in negotiation than those in the capitals. The latter, on the other hand, often feel that the Brussels-based civil servants are not fighting sufficiently hard for their country's interests.

293. At higher level, the independence of Member State representatives generally increases. The permanent representatives are all highly respected figures in their governments and can often persuade the capital to change its views on issues.

294. For the CEECs, contacts with the staff of permanent representations in Brussels is essential. All of the CEEC missions in Brussels are aware of this already. It is worth emphasising however that contact 
should not only be maintained at the highest level but also at the level of diplomats taking part in the working groups of the Council.

\subsection{The Commission}

295. The Commission's role in the preparation for the European Council in Luxembourg and for the following negotiations are crucial even though all decisions will be taken by the Council.

296. The Commission first presented its "Agenda 2000" package to the Council in September and October 1997. In its presentation and answers to Council members' questions, it already has an opportunity to influence considerably, and perhaps decisively, the decisions which the Council will make.

297. The role of the Commission in the negotiations will be to assist the Council in its work and maintain the flow of information to the Parliament. In fact, it will do much more.

298. The Commission will almost certainly set up a powerful enlargement task force, directed by a director general and having a considerable staff drawn from all the relevant services of the Commission. This task force will have access to several hundred officials, who have experience of the matters being negotiated. It will also have access to as much expertise from outside the Commission as it wants and needs.

299. In the previous enlargement, the Commission undertook the preparatory phase of reviewing the whole of the acquis with the applicants. The same process is likely to be followed again, although this stage may take far longer than it did in previous enlargements.

300. In the actual negotiations, the Commission will have the responsibility of preparing papers on all the most difficult aspects of the negotiations, which it will submit to the Council. It will propose solutions to the different problems which occur and seek agreement between the Member States. It will have the closest contact to the individual Member States and will be consulted by the Member States on most important questions. It will also keep contact with the applicant CEECs to explain to them what is going on and to ask them what their latest thinking is.

301. In other words, the role of the Commission will be to facilitate the negotiations on the Union side and to design solutions to the most difficult problems. There is little that the Commission can do to oppose key decisions taken by the Council (for instance if the Council decides that negotiations should go more slowly), but in the normal progress of negotiations, the Commission can have a determinant role.

302. The College of Commissioners itself may not be asked to take too many decisions in the enlargement process, partly because decisions will be taken by the Council of Ministers and partly because on minor matters the Commissioner responsible for the negotiations will probably obtain a delegation of powers to enable him to decide without reference to the College. However, major matters such as the offering or requesting of transitional periods in the negotiations will be discussed in Commission which will make proposals to the Council. It is important to remember here that each Commissioner is collectively responsible for decisions taken and therefore it is important to influence all Commissioners not simply the one responsible for the negotiations.

303. In the Commission and in COREPER, the Secretary General of the Commission, as its representative, will play an important role. Within the Commission, the enlargement task force, yet to be created, will be the key body with which the CEECs will deal. However, it must be remembered that in 
the technical areas of negotiation, it will be the technical directorates-general which have the greatest influence. If there is a problem in the treatment of national monopolies for instance, it will be the Directorate-General on Competition Policy which has the crucial role to play.

304. The Commission delegations in the CEECs will in general not have a major role in the negotiations, though they will be involved and will be important providers of information. The fact that the CEECs will all have large missions in Brussels during the negotiations, and that CEEC ministers and officials will be continually required to travel the short distance to Brussels and will develop close relations with Union negotiators, means that the delegations are less significant. They will however be deeply involved in the implementation of the Pre-Accession Strategy and the Accession Partnerships (outlined in "Agenda 2000"). This means that there will be little change in the current situation: the delegations are important in the implementation of the Phare Programme but have a very limited "political" role. This situation is in contrast to the bilateral embassies of the Member States.

305. The CEECs will obviously want to keep close relations with the Commission during the whole course of the negotiations; and this applies not only to the enlargement task force and its Commissioner but also to all the Commission services which are implicated in the negotiation process. Again, contacts are necessary at all levels not just simply at the top of the hierarchy. These contacts should be maintained both through the CEEC missions in Brussels but also directly between officials in the CEEC capitals and the Commission. It is most important that these relations are on a flexible and amicable level between people who respect each other's professionalism.

\subsection{The European Parliament}

306. In theory, the European Parliament does not have an important role during the negotiations. The Union Treaty only requires that the Parliament agree to each accession by a simple majority.

307. This is also, however, to underestimate the growing significance of the Parliament. The EP was the great winner in the disappointing (draft) Amsterdam Treaty, its powers increased through the extension of the so-called co-operation procedure to new areas. The Commission lives in considerable trepidation of the opinions of Parliament, which effectively controls much of the discretionary spending in the budget.

308. The growing power of the Parliament will be felt during the negotiations as it expresses its opinions on its various concerns. While these opinions need not be taken into account by the Council, the Council will nevertheless try to avoid upsetting Parliament too much, because accession needs a simple majority at the end of the day.

309. For the CEECs, the Parliament is probably more difficult an institution to influence than either Council or the Commission. The first obvious parliamentarians to influence are those which participate in Parliamentary Association Committees with each CEEC under the association agreement. But these Members of Parliament are liable to be favourable towards the candidate country in any case. The next groupings which will take collective positions on accession negotiations are the political groupings such as the Party of European Socialists or the European Peoples' Party. The CEECs should consider keeping both the leaders and deputies of the parties informed but should also maintain some contact with the civil servants which serve the different parties. Finally, there are the Committees of Parliament which will also have a considerable input into the discussions on enlargement, notably the Committee on Foreign Affairs and the Committee on External Economic Relations. 
310. Of course, as the negotiations draw to a conclusion in the Council, it will be most important for the CEECs to increase their lobbying of Parliament.

\section{The Role of CEEC Institutions in the Accession Negotiations}

311. The accession negotiations will mean a major change for many of the CEEC institutions, both those in country and those in Brussels, in the Member States and in third countries. The effort required will be enormous and very varied.

\subsection{The Co-ordination Mechanism}

312. The first requirement of the CEECs is to have a strong co-ordination mechanism in place well before the negotiations begin. The preparation for the negotiations and the negotiations themselves will become extremely complex. In fact, the negotiations will eventually turn into an enormous number of mini-negotiations between officials of both sides which will be extremely difficult to control, without a significant co-ordination mechanism.

313. The functions of the co-ordination mechanism include:

- the co-ordination of the impact analysis of the Community acquis on the CEEC economy and society - without such an analysis, further steps in determining a negotiating position become very complex;

- the prioritisation of CEEC requests for either transition periods or temporary derogations;

- the sequencing of the introduction and implementation of the acquis;

- the construction of a negotiating mandate to be approved by the government; this must be backed up by different scenarios for the negotiations;

- the overall co-ordination of the negotiations, ensuring that the government's overall objectives are met in as efficient a way as possible.

314. There is no one institutional format for the co-ordinating mechanism, but there are certain indicators of the qualities it must possess:

315. It should have the total backing of the national government and the prime minister, in order to keep so-called "turf battles" to a minimum and to make sure that other line ministries do not make deals independently of the chief negotiator and the co-ordination centre. Without the highest possible political backing, it will not succeed, and confusion and second-best solutions will be the rule. While the co-ordinating institution can be the foreign ministry, accession negotiations are a matter of domestic not foreign policy. Foreign policy will play an absolutely insignificant role in the negotiations. The co-ordinating institution should have staff with technical competence. It is not sufficient just to have a generalist staff. Lawyers, economists, and staff trained in some of the technical matters of the internal market are essential. The staff should be of course multi-lingual and, if possible, with experience inside the Community, though this is not essential.

316. The advantage of the foreign ministry in this co-ordinating role is that the staff is used to dealing with the Community and its Member States, that it has usually considerable negotiating experience and that it generally commands considerable authority within government. A disadvantage is that the foreign ministry frequently has staff trained in diplomacy but not in the legal, economic or technical detail of the 
internal market. A specific ministry for European integration is another possible institutional solution. Its success however depends on it being at the heart of government with total support from the top.

317. Perhaps, more important than where the institution is situated is the degree of stability it enjoys during the course of the negotiation. One institution should be responsible for co-ordination throughout the negotiation process, and as far as possible the staff of the institution should change as little as possible. There will of course always be changes taking place through the political process. However, the importance of building informal confidence bridges between the negotiators in the CEECs and those in Brussels should not be overlooked.

318. In all the CEECs, this co-ordination mechanism exists in one form or another. The necessary networks between the European integration units in the different ministries and agencies of government also exist. The key task between now and the opening of the negotiations is to ensure that the mechanism works smoothly and efficiently.

319. The EU will almost certainly negotiate from the position that new Member States have to accept the whole acquis immediately on accession, though this position will be modified slightly as the negotiations progress. Between now and the opening of negotiations, the CEECs must therefore define their negotiating positions. The co-ordinating institution must by then have a clear idea of the areas of the negotiation which are going to create difficulties and must be advising the government of the choices which will have to be made. While the co-ordinating institution cannot itself undertake the technical work in defining the individual problem areas and possible solutions, it must be in a position to propose overall negotiating solutions to the government that are feasible and take into account the main interests of the country.

\subsection{Integration Teams in the Ministries}

320. The need to have significant groups in each government ministry working on the negotiations is clear to all. In the key ministries, such as agriculture or the economy, these groups will become very large and absorb considerable resources. The staff involved in the negotiations will all have to be able to work in English or another Community language, and they will have to know Community policy and law in their sector well.

321. One of the main functions of these groups will be to provide position papers to the co-ordination institution and the negotiator on those areas of the acquis which will cause problems for the country. These papers will be required for transmission to the EU negotiators to explain the particular problem of the CEEC applicant in each area.

\subsection{CEEC Missions in Brussels}

322. The complexity of the negotiation process makes it absolutely essential that the CEECs establish larger and more powerful missions in Brussels for the duration of the negotiations.

323. On numerous occasions, informal meetings bearing on the negotiations will be called at very short notice, and the CEEC missions will be asked to attend, perhaps with only 30 minutes notice. The missions will need a level of staffing which will enable them to have specialists in most areas of the negotiations always on hand; this means as part of the mission. It will not always be possible to get instructions from the capitals of the CEECs for such meetings and ex-post rather than ex-ante 
co-ordination will be necessary. During the previous enlargement, the EFTA candidates maintained large missions during the negotiations in Brussels with 50 or more officials; and because of the EEA agreement these countries had less to negotiate than the CEECs will have!

324. The missions will also have the duty to maintain contact and friendly relations with Commission officials, Council negotiators and officials and the Permanent Representations of the Member States of the EU. This role is immensely important if the CEECs are to avoid misunderstandings arising in the negotiations. There is little that is more important than good personal, informal relations with the other party. These relations will however be built up on mutual respect for the intellect and honesty of the parties rather than on their hospitality!

325. The missions in Brussels will need to be given more freedom and room for manoeuvre than the capitals will instinctively want to give them. The experience of most countries which have negotiated with the Union is that ex post they did not allow the missions enough freedom to decide. The officials working in the missions will have a much better appreciation of the negotiating possibilities in detail than the officials in the capitals. In general, if one considers the existing Member States, it is those which give more room for manoeuvre to their permanent representatives in Brussels which are the most successful in negotiations.

\subsection{The Public Relations/Information Function}

326. The negotiations will continue for at least two years and maybe longer. They will become extremely complex and very difficult to understand, even for the people in the process. In such a situation, it will be essential to have a dedicated public relations team dealing with:

- the domestic consumers, who will want to know both what changes are likely to affect them and also how the negotiations are progressing;

- the requirements of the embassies and other CEEC official representations abroad;

- the EU Member States and third parties, to explain clearly CEEC positions on particular problems.

327. The public relations / information function is not an "optional extra" in the process of negotiations; it may be at the heart of the process. It will be important to keep public support for accession during a period where most of the news from Brussels is liable to be about disagreements between the CEEC and the EU. Such a long period of essentially negative feedback can have a disastrous impact on the popularity of accession and lead to a "no" vote in referenda after the end of the negotiations (cf. Norway).

328. The supplying of the latest information to the CEEC embassies in the EU Member States but also in third countries is a most important function. The responsibility lies with the foreign ministry, but the public relations/information mechanism must always keep the needs of the embassies in mind, especially in the area of wide-diffusion printed material.

329. For an external audience, it is essential to put across the CEEC arguments effectively, in order to keep support for the enlargement process in the EU. While this information function should obviously concentrate on the EU Member States (and in part at least be organised by the CEEC embassies in those Member States), it is also important to maintain a flow of information to important third countries. The United States is the first to come to mind, but other OECD countries will also be important backers. The same applies to the multilaterals, such as OECD itself, the World Bank, IMF, WTO and so on. 
330. The public relations function needs to be set up immediately in order to play a role from the beginning of the negotiations. It should be staffed by professionals and its senior staff should have direct access to ministers involved in the negotiations, to the head of the co-ordinating institution and to the chief negotiator.

\subsection{Contacts Outside Government}

331. One serious danger is that the negotiation of parts of the acquis may be carried out by civil servants without contact with those in the economy and society who are affected by the resulting agreements. In order to guard against this, it will be important to establish flexible arrangements to consult with business, trade union, professional and other interests.

332. Ideally, light structures might be established linking these interests to the preparation of the negotiating position. Beyond this, the structures must also be designed to provide opinions to the negotiators on different points of the negotiations throughout their duration. The flexibility of the structures is most important. Negotiators require instant answers to questions during the negotiations. There is little use in having business organisations which, in order to answer a question, need to hold a general assembly of all their members! The earlier these interests are brought into the preparation of the negotiations, the easier it is for them to prepare their positions on the different issues and the more useful they will be to the negotiators.

333. The final negotiating position is of course a matter for government. Governments must not be "captured" by agency-specific interests in dealings with these representatives of different economic interests, especially when the different interests have substantial economic power or prestige in society (for instance state-owned enterprises or politically involved labour movements).

\section{CEEC Relations with Bilateral and Multilateral Institutions}

334. It is clearly not sufficient for the CEECs to develop contacts simply with the different institutions in Brussels and the other centres of the EU. Decisions being made in Brussels are usually the result of positions taken in the Member State capitals, and it is here that the CEECs should seek to exert influence.

\subsection{Bilateral Relations with Member States}

335. There are perhaps four important levels of contact for the CEECs in the Member States: those with government, with parliament, with significant pressure or representative groups and with major enterprises.

336. Contacts with government are the most obvious and in many ways the simplest. These contacts exist already and should be promoted throughout the negotiations. Though many EU Member State politicians will visit the CEECs, clearly the burden of travel will fall mainly on the CEECs themselves. These visits should in an ideal manner be co-ordinated by the co-ordination institution in the CEEC capitals, but on many occasions the visits will be of an ad hoc nature. While the main burden will fall on the minister responsible for the negotiations, the foreign minister and the prime minister, other members of the government must also be brought into the schedule of visits, especially those to their direct counterparts in the Member States. The visits will concentrate on the Member State ministers and officials 
directly concerned in the negotiations, the foreign ministry, and, if present, the ministry for European affairs (or co-ordination body - $\mathrm{SGCI}^{28}$ in Paris or Cabinet Office in London).

337. As enlargement in the EU is decided by unanimity, it is dangerous to suggest that CEECs should give priority to contacts with certain Member States against others; any single Member State can block accession. It is perhaps more important to work to change the mind of the potential opponents of accession than to encourage those countries which are positive towards enlargement. Frequently however, Member States will not be simply for or against accession; they will all have problems with different parts of the negotiations and therefore maintaining contact with all Member States will be necessary.

338. While it will not be possible to expend large resources on contacts with national parliaments, it should not be forgotten that they will also have to agree to accession in the end, just like the European Parliament. They cannot therefore be ignored. Ideally this relationship is maintained by visits from either CEEC governments or CEEC parliamentarians. Convincing national parliamentarians is also an effective way of maintaining general popular support for enlargement in the EU.

339. Contact should also be nurtured with large national pressure groups and with major national and multi-national enterprises in the Member States. In many Member States, these organisations have a major impact on the opinion of government; in Germany for instance, the DIHT (the Chambers of Commerce representation), or the BDI (the representative of private companies) or the DGB (the trades unions), have great power and authority and are often consulted by government.

340. Clearly, much of the strain of these contacts must be borne by the embassies of the CEECs in the Member States. The embassies must be tied into the network of the co-ordinating institution in the CEEC capital; where this is not the foreign ministry, the latter will also be deeply involved in the networking of the embassies.

\subsection{Bilateral Contacts with Third Countries}

341. Contacts with third countries can be extremely important; this applies especially to contacts with the United States of America. This is not necessarily a popular message in some quarters of the EU and is something that should be done relatively discreetly. However, enlargement is an important part of the development of the post-Cold War security system, in which the United States is playing a very significant role. It is therefore a process in which the Americans must take a considerable interest and will attempt to exert a diplomatic interest in its dealings with the Union. The United States and many other third countries also have important economic interests in the accession countries and are therefore interested in the smooth process of accession.

\subsection{Contacts Between the Negotiating CEECs}

342. An important question is whether the negotiating CEECs should institutionalise the contacts between themselves in the run-up to and during the negotiations. Experience in the past has shown that such co-ordination is difficult. It did not really work during the negotiations for the first association

28. The Secretariat of the Interministerial Committee for European Matters (Secrétariat général du Comité interministériel pour la co-opération économique internationale) deals with most aspects of European affairs, except foreign and security policy. 
agreements in 1991, nor did much co-ordination take place between the EFTA countries in the last accession negotiations.

343. In spite of the difficulties, some attempt should be made at least to maintain contact on common problems in the negotiations; these could be for instance the form of the structural funds assistance after accession or the negotiation of free movement of workers or perhaps transition periods for certain costly environmental directives. These contacts can be maintained both between the missions in Brussels and between capitals.

344. The interests of the CEECs are often so divergent or are felt to be so divergent that this co-ordination will be ineffective; but the potential gains from some co-ordination on certain problems are great enough to make the attempt worthwhile.

\subsection{Contacts with Multilateral Organisations}

345. CEEC contacts with multilateral organisations are potent ways of reaching authoritative bodies which will support the cause of accession. This is true even where the CEECs are not Members of the organisation. This is for instance the case of the OECD, where only three CEECs are Members, but which, as a very important part of the network of industrialised countries, can have an important influence on the international community and particularly the EU Member States. The World Bank, which has concentrated its activity recently on supporting the process of European integration, and the IMF and the UN and its agencies should also be used to influence the process.

\subsection{Contacts with Pressure Groups at the EU Level}

346. Pressure groups at the EU level vary in their leverage on Community processes considerably. Traditionally, the farming lobby has been the most successful lobby group (COPA), and it is still powerful, though perhaps less so than in the 1970s and 1980s. Representatives of industrial sectors such as EUROFER (iron and steel) or CEFIC (chemicals) can be extremely influential, as they have often shown in anti-dumping cases. The power of these lobbies, including consumer lobbies, has been growing and will continue to do so.

347. As certain parts of EU industry or indeed agriculture may turn against enlargement, some attention should be paid to these organisations, which have influence both on the Commission and the European Parliament.

\section{The Use of CEEC Resources}

348. To adequately cover all of the tasks outlined in this paper exceeds the human resource capacities of all of the CEECs. The negotiations are important, but they cannot absorb the whole resources of government.

349. The CEECs will have to dedicate more resources to the negotiations; there is no alternative to this. That this will be an additional cost on already strained budgets is also clear. The question is how to obtain more resources economically and use them efficiently.

350. In the use of direct government resources, priority must be given to the negotiations themselves. This suggests that the co-ordinating institution, the chief negotiator's office, the negotiation teams in the 
ministries and the Brussels mission should have priority. To obtain maximum efficiency, it is necessary for this large group of people to work as a close team. Serious thought must be given now to structuring this core group and relating it to other parts of the negotiating complex in order to obtain maximum efficiency. Above all, some thought should be given to the communication between the different members of the team; for instance whether there should be dedicated and confidential electronic mail (e-mail) and telecommunication links between them.

351. Government should also make wide use of domestic expertise from outside government. This expertise can be obtained from the universities but also from business and other parts of the national economy and society and is especially valuable in complementing the information from within ministries.

352. Foreign expertise will be necessary in certain key areas and can generally be financed through Phare or one of the bilateral assistance programmes. The problem in the use of foreign assistance is to identify good quality experts on specific subjects who can spend the required amount of time in the CEECs. In this, the EU Member States and the EU itself can help by supplying to the CEECs the names of the officials who can be contacted in their administrations to identify suitable resources.

353. Perhaps the most important immediate task for the CEECs is to accelerate the organisation of the whole negotiating network, with forecasts of the resource needs and availability over the coming year. In such tasks, the SIGMA Programme can certainly be a considerable support to the negotiating CEECs. 
Chapter 5: The European Commission and the Negotiation Process in the Previous Waves of Accession to the European Union

By Francisco Grannell ${ }^{29}$

29. Francisco Granell is Director, DG VIII, European Commission, Brussels. 
354. In accordance with the decision taken by the EU Foreign ministers in December 1997 to accept the recommendation of the European Commission to open enlargement negotiations with six states, while leaving formal talks with an additional five applications for later, on 31 March 1998 the European Union will start the negotiations for membership of five central and eastern European states (Poland, Hungary, the Czech Republic, Estonia and Slovenia). Cyprus has also been included in this wave in accordance with previous decisions already taken.

355. According to the Treaty of Maastricht the European Union is an open area in the sense that any European country wishing to pool its resources to share the ideal of preserving and strengthening peace and liberty may join the European Union. Countries applying for membership must adopt the full Acquis Communautaire.

356. Based on this principle and the previous ones established by the treaties of Paris, creating the European Coal and Steel Community, Rome, creating the European Economic Community and EURATOM, several countries became full Members of the European Community during the period 1973/1986. Several others became full Members under the Maastricht Treaty (1992), which established the European Union.

357. The six founding Members of the EC were Belgium, France, Germany, Italy, Luxembourg and the Netherlands. Three more states, the United Kingdom, Denmark and Ireland were admitted from 1 January 1973 in the first wave of EC enlargement. The second wave of enlargement involved Greece, which joined on 1 January 1981, Spain and Portugal, which both jointed on 1 January 1986. Finally Austria, Sweden and Finland jointed the EU on 1 January 1995. Eastern Germany had earlier joined the European Union following the merger of the two Germanys after the fall of the Berlin wall.

358. The EU, after having expanded from six to fifteen Members, once again faces the challenge of enlargement. Fifteen countries have applied for membership (Table 1.) and although some of these countries are not currently eligible for membership, they have not withdrawn their applications. With respect to Malta, both sides decided to freeze the application for membership and to seek for a reinforcement of economic co-operation. In the past only the application presented by Morocco had not been accepted for geographical reasons. In the case of Switzerland and Norway, their government have expressed the wish that future relations with the EU would continue as smoothly as possible on the basis of greater exploration of the existing agreements, taken into account the 'No' referenda on the EEA for Switzerland and on EU membership for Norway. A special process that will involve specific meetings with a view to discuss various problems has been established with Turkey because there is as yet no decision on Turkey's request to join the Union. 
Table $1^{30}$. States which Have Put in a Request for Accession to the EU

\begin{tabular}{|l|c|c|c|c|}
\hline & $\begin{array}{c}\text { Request of } \\
\text { Accession }\end{array}$ & Population & $\begin{array}{c}\text { Income per } \\
\text { capita (in US\$) }\end{array}$ & $\begin{array}{c}\text { Commission } \\
\text { Opinion }\end{array}$ \\
\hline Turkey & 14 April 1987 & 58.8 & 2000 & 18 December 1989 \\
\hline Cyprus & 4 July 1990 & 0.7 & 10000 & 30 June 1993 \\
\hline Malta & 16 July 1990 & 0.3 & 8000 & 30 June 1993 \\
\hline Switzerland & 26 May 1992 & 6.8 & 36000 & \\
\hline Norway & 25 November 1992 & 4.3 & 25000 & 24 March 1993 \\
\hline Hungary & 1 April 1994 & 10.2 & 3000 & 17 July 1997 \\
\hline Poland & 8 April 1994 & 38.5 & 2000 & 17 July 1997 \\
\hline Romania & 22 June 1995 & 22.8 & 1100 & 17 July 1997 \\
\hline Slovakia & 27 June 1995 & 5.5 & 2000 & 17 July 1997 \\
\hline Latvia & 27 October 1995 & 2.6 & 2000 & 17 July 1997 \\
\hline Estonia & 28 November 1995 & 1.5 & 3000 & 17 July 1997 \\
\hline Lithuania & 8 December 1995 & 3.7 & 1500 & 17 July 1997 \\
\hline Bulgaria & 16 December 1995 & 8.9 & 1500 & 17 July 1997 \\
\hline Czech Republic & 23 January 1996 & 10.4 & 2500 & 17 July 1997 \\
\hline Slovenia & 10 June 1996 & 1.9 & 6300 & 17 July 1997 \\
\hline
\end{tabular}

359. The situation of each of these countries is different. For instance, the membership negotiations with Switzerland, which were planned to take place together with the negotiations with Austria, Sweden, Finland and Norway, never started due to the Swiss "No" vote in a referendum on the European Economic Area on 12 December 1992. With Norway an accession agreement was negotiated which was subsequently rejected by the Norwegian people in a referendum on 28 November 1994. The Norwegian people had rejected membership on one previous occasion, in a referendum held on 24 September 1972.

360. The European Commission has presented Opinions on the application for membership for all the 15 applicant countries listed above, except for Switzerland. In these Opinions the consequences of the accession of each individual country and the issues that must be addressed for this country to join the EU are reviewed. The European Commission has also published, on each occasion, a general overview of the global impact of the future enlargement. The latter assessment serves to safeguard the EU's ability to function effectively (1)(2)(3).

361. Traditionally there has been concern in the EU about the impact of enlargement on the deepening of the European Integration or the 'quality' of the Union. Thus far enlargement has not affected the EU's ability to safeguard the 'quality' of the European Integration process. The Community enlarged from six to fifteen while simultaneously improving the quality of integration in a neo-functional trend, initiated with the Common Market for Coal and Steel and culminating in the present Three Pillar approach introduced by the Maastricht Treaty on European Union. New Member States have generally not suffered insurmountable problems of adaptation.

30. Source: F. Granell: “Catalunya I l'ampliació e la Unó Europea”, Nota d'Economia, May-August 1996. 
362. The question remains, today, how integration can be deepened when the community will include 20 or more Members. This question is even more crucial on the eve of Monetary Union.

363. In this respect the European Commission must be careful about the functions of the whole system. What will happen to the institutions, the representation of the Member States in the institutions and what will be the impact of enlargement on the decision-making process? How the budgetary questions of an enlarged community be resolved? How can the Acquis Communautaire be preserved?

364. This Acquis Communautaire is the term employed to describe primary Community law - the Treaty of Rome and other such treaties - and secondary community law adopted under these treaties since the European Union was founded (Regulations, Directives and decisions). The Acquis also comprises all the relevant case law of the European Court of Justice and the relevant Second and Third Pillar guidelines.

365. As the highest executive body of the European Union, the European Commission initiates policy and drafts detailed measures for its implementation. The Commission also has the task to ensure that EU regulations are observed. The Commission has the right to initiate proceedings at the European Court of Justice if Member States, individuals or companies infringe any part of the Acquis Communautaire. The procedure for bringing such a case is the subject of Article 169 of the Treaty.

366. In this respect the full acceptance of the Acquis Communautaire is a key element of the 'rules of the game' which bind both candidate states and Member States. This principle forms the basis condition for the effective participation in European institutions by candidate states.

367. In previous enlargements the principle of accepting the full Acquis Communautaire always formed the basis for the negotiations. This principle is not negotiable for the EU in the framework of further enlargements. The scenario for the start of the negotiations in previous accessions was always the same. At the first ministerial meeting of all previous accession conferences the candidate states agreed on the basic principle basis that the full Acquis must be taken on by the new Member States. The negotiations subsequently focused on the transition periods to be granted to the candidate states in order to allow them to adjust to the requirements of EU membership. Transition methods were the sole method of dealing with adjustment problems, changes in Community rules or permanent derogations were not deemed acceptable. This means that new Members have had - always in previous accessions - to accept the EU's Acquis in its entirety at the moment of accession.

368. The Acquis has extended enormously since the start of the European Integration process. The 1995 enlargement included the acceptance by the candidate countries of the traditional EU regulations and the new pillars introduced by the Maastricht Treaty on European Union (4):

- the institutional provisions: governing intergovernmental and supranational EU bodies, their composition and interactions with the logical numerical adaptations;

- the legal framework: the different kinds of Community treaties, regulations, acts and other texts;

- the financial regulations establishing the Union's budgetary resources and expenses, the European Development Fund (EDF) and the European Investment Bank (EIB) by laws;

- the norms establishing the free circulation of goods, persons and capital inside the EU, the freedom to provide services and the freedom of establishment; 
- the common Community rules and standards concerning approximation of laws, fair competition and monopolies, indirect taxation, veterinary and plant health, commercial law, etc.

- the common policies: Common Agricultural Policy (CAP); Common External Tariff and Commercial Policy; Development Policy; Regional Social and Cohesion Policy; Transport Policy and Trans-European networks; Consumer and Health Protection, Research and Information policies, Education, Statistics, Energy Policy; Fisheries Policy; Industrial Policy;

- Economic and Monetary Union (EMU) as a further stage of the European Monetary System;

- the so-called new "pillars" of the TEU;

- the Common Foreign and Security Policy (CFSP);

- Co-operation in the field of Justice and Home Affairs;

- the rights and duties derived from the concept of "Citizenship of the Union" included in the first pillar of the Maastricht Treaty.

369. Furthermore, in addition to present obligations (which can include participation in the Schengen agreements as well), applicant countries must be able to accept the future obligations generated by membership of the dynamic body which is the European Union.

370. The new Amsterdam Treaty is considering the possibility of a more flexible Community under "Provisions on closer co-operation" and the European Commission has expressed its willingness to accept some degree of flexibility, even though not with regard to the Acquis Communautaire questions. The reason for this is that if flexibility is allowed to such an extent that present or future Member countries can apply to only a part of the EU system, tremendous problems will emerge for the management of the overall legal and administrative system. Since the principle of the acceptance of the full Acquis Communautaire is not negotiable, previous enlargement negotiations had two main objectives; the creation of transitional periods to allow for the incorporation of the Acquis Communautaire into the legislation of the new Member State and the authorisation of certain temporary derogations when necessary. No permanent derogation has been allowed, even if in some cases "imaginative" solutions to cope with some problems were required. That means that the Treaty of Accession just contains the temporary exceptions and the technical adaptations to the general rule of the full acceptance of the Acquis. According to the experience in the past, the process conducing to membership has been:

$\Rightarrow \quad$ The country applied;

$\Rightarrow \quad$ The Commission asked questions on the economy and the legal framework of the applicant country, to prepare an Opinion on how potential problems posed by the accession of the candidate state can be addressed. In recent accessions this has included questions in relation to the political criteria;

$\Rightarrow \quad$ The Commission published one Opinion for each individual applicant country;

$\Rightarrow \quad$ The Council decided to open or not to open negotiations with each individual applicant country;

$\Rightarrow \quad$ Negotiations in the form of intergovernmental conferences between the EU's Member States and each of the candidates started;

$\Rightarrow \quad$ The Commission created an enlargement Task Force to help the negotiating process and to play a role in connecting requests of temporary derogations by applicant countries and the position of 
the Member States after a full screening of the applicant country regulation matching or not EU's regulations;

$\Rightarrow \quad$ The Member States agreed among them on the EU's negotiating position and then agree with the applicants in the formulation of the temporary derogations to be included in the Accession Treaty;

$\Rightarrow \quad$ The articles of the Accession Treaty are prepared. If there is no article regarding one particular part of the Acquis Communautaire then it means full acceptance of the Acquis without any need of temporary transitional period;

$\Rightarrow \quad$ The European Parliament approves the Accession Treaty text;

$\Rightarrow \quad$ Signature of the Accession Treaty by the EU's Member States and by the accession country;

$\Rightarrow \quad$ Ratification process in the EU's Member States and in the applicant country according to the constitutional requirements and procedures.

371. Table $2 .^{31}$ below shows the negotiating process in a schematic form:

31. Source: F. Granell: “The European Union's Enlargement Negotiations with Austria, Finland, Norway and Sweden”, Journal of Common Market Studies, Vol 22, No. 1, March 1995, pages 117-141. 


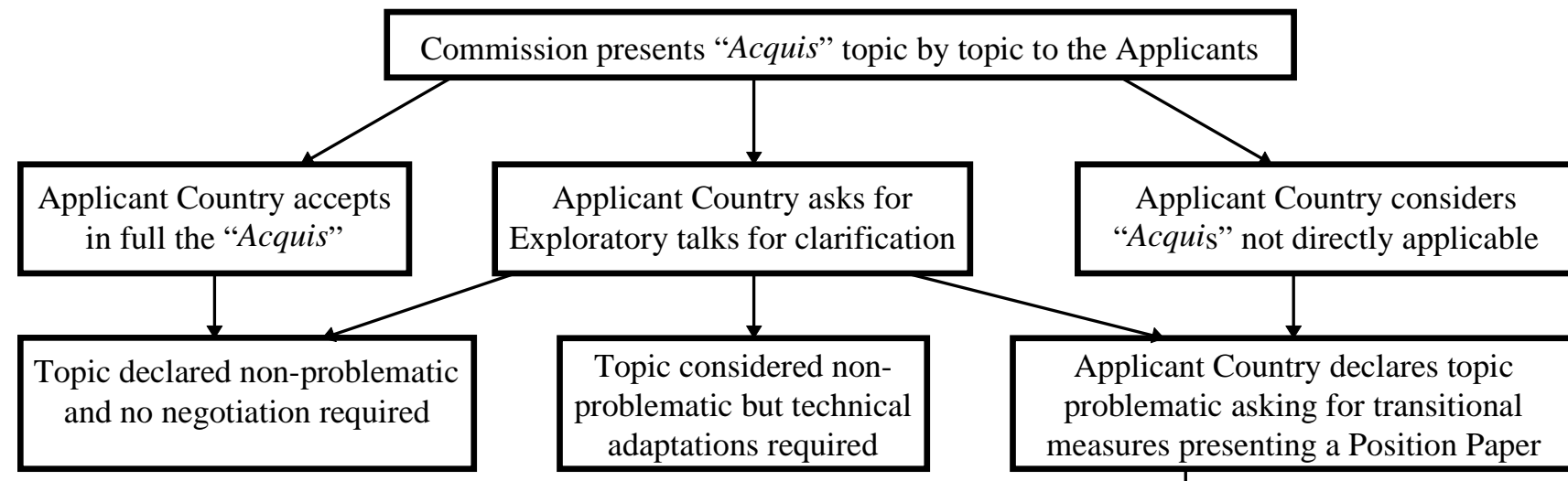

Commission made the Draft Common Position of the 12 matching to the requests of the Applicant and the "Acquis" or proposition of a "Third Option"

Council accepts the solutions proposed by the Commission in the DCP converting DCP in a $\mathrm{CP}$

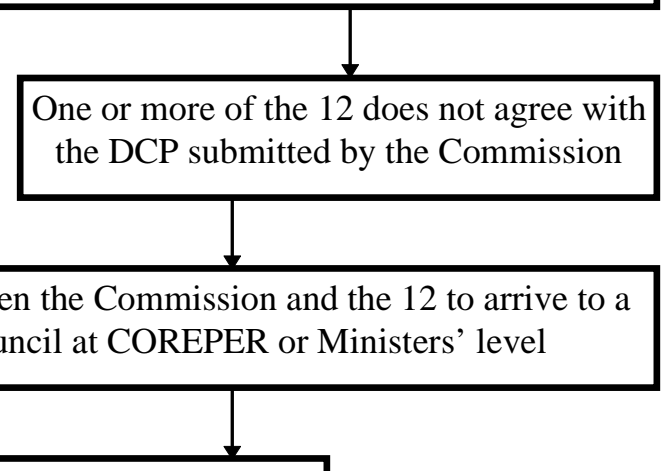

Presentation of the $\mathrm{CP}$ with the solution proposed by the 12 to the Applicant Country at a Deputy or Ministerial Negotiation Session

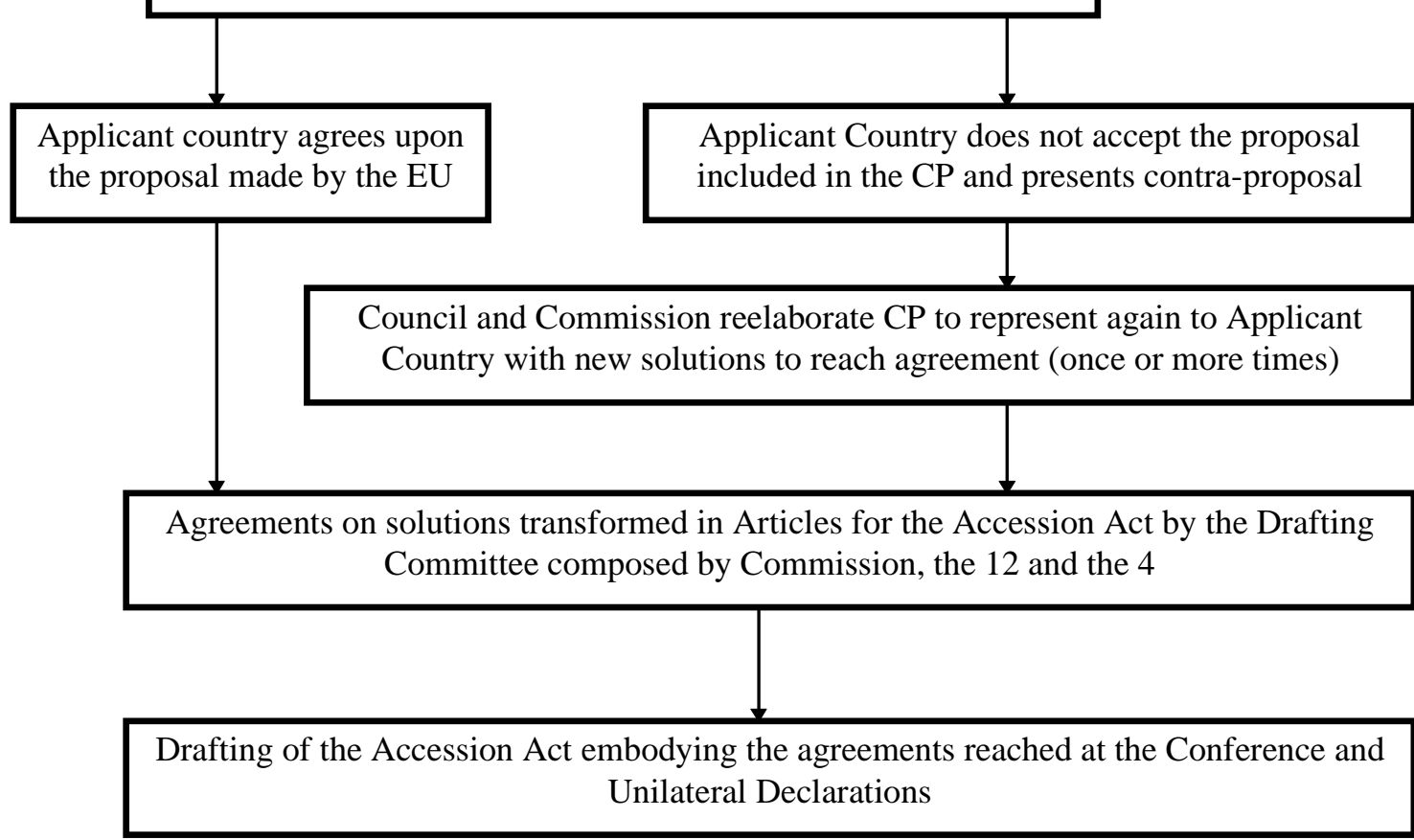

DCP: Draft Common Procedure

CP: Common Position 
372. The legal impact of the membership is not limited to the text of the Accession Treaty. Membership in the EU brought some 40000 more pages of EC legislation into the well developed Finnish legal system. This only concerned directly applicable EC regulations. In the case of previous enlargements the impact of the Community membership in the domestic system was proportionally even more important; countries like Greece, Spain and Portugal had not previously harmonised their legislation with EC norms, unlike Finland, Sweden and Austria which had harmonised their legal system with EU law in many fields under the European Economic Area Agreement.

373. In view of the above, it is perhaps wiser to make a comparison of the new enlargements with the Greek, Portuguese and Spanish experience of joining the EU rather than to make predictions about the current enlargement based on a comparison with the Finnish, Austrian or Swedish cases which were very advanced in many policy areas covered by the Acquis Communautaire.

374. Finland, Austria and Sweden had relatively short processes of negotiation for membership: Finland, for instance, applied for membership in March 1992 and became full Member of the EU in January 1995. Spain and Portugal received completely different treatment than that received by Finland, Sweden and Austria. They applied for membership in 1977 and only became full Members in 1986 and even very long periods of transition with temporary derogations were set because those candidate countries were not fully prepared to respond from the first day of membership to the commitment to take over in their national legislation the Acquis Communautaire. Spain and Portugal had to change or even create certain laws and administrative organs to cope with the EU's requirements, and that obliged a sometimes difficult internal legislative process with the involvement of the national parliaments.

375. In many cases the adaptation to EC legislation will constitute a heavier obligation for the current candidate states than for those states which negotiated Treaties of Accession in the 1970's and 1980's, because the volume of EC legislation requiring national implementation, often requiring Parliamentary enactment, has greatly increased during the Single Market process and the process to the Economic and Monetary Union. In any case at the end of the transitional period the Acquis Communautaire will apply to the new Member States in the same way as to the present Member States.

376. A state acceding to the EU must set up an efficient national preparatory and decision making machinery for European affairs in order to protect the national interest in the perspective of the full acceptance of the Acquis Communautaire.

377. The major concerns of the applicant countries are often a consequence of the national regulations and legal and economic traditions. Differences in minimum standards for health, safety and environment will require detailed expert discussions. Free movement of agricultural and industrial goods in the context of the Single Market must be combined with an adequate timetable to adopt the Common External Tariff and the EU's commercial policy vis-à-vis developed and developing countries. Competition and antimonopoly regulations and State Aid must be adapted in conformity with Community rules by the time of Accession.

378. Conservation of natural habitats, wild fauna and flora and some other conservation measures must be created in acceding countries when not previously existing. Energy policies, including policies relating to nuclear energy — must be adapted to the Community Acquis.

379. The main issues over which problems arise generally during enlargement negotiations are Agriculture, Taxation and Regional and Structural Policies. The Common Agricultural Policy frequently requires the adoption of a different model in terms of prices and administrative requirements than the one known to farmers of the applicant states. The need for adaptation varies according to the national model. 
In the field of the Value Added Tax, excise duties and the travellers' allowances the applicant countries can be granted transitional periods for harmonisation and exemptions but nothing else. The regional and structural policies are of great importance to relatively less prosperous states in the Union, and it is necessary to remember that all eastern European and Mediterranean applicants must be classified under this category.

380. Apart from these general questions every single enlargement negotiation must deal with other issues having special political and economic importance for a specific applicant countries. In the case of the Enlargement Negotiations with Austria, Finland, Norway and Sweden, some of the specific issues that can be mentioned are:

- Road transit agreement requested by Austria in order to maintain the right to restrict the transalpine transit of heavy vehicles through Austria and bilateral to and from Austria (already covered by the 1992 Transit Agreement lasting to 2004). It was the only solution of this question in the final round of negotiations on 1 March 1994 which permitted the Union and Austria to conclude the negotiations.

- Protocols on the special rights for the Sami people in Sweden, Finland and Norway.

- the Aland Islands are to benefit for special arrangements (approved by 73.7 per cent of the Alanders in a separate referendum held on 20 November 1994).

- Finnish insurance companies will be obliged to separate their pension schemes from other insurance activities, and the market will be open to companies from other countries.

- The new Members are being granted a five-year adaptation period before applying in full the right of foreigners to acquire secondary residences on their soil.

- Because of its geographical position and the exclusion of sea transport from the European networks project, Finland obtained a declaration stating that due attention must be paid to Finnish sea transport in the relevant Union initiatives.

381. Based on the combined considerations I have discussed, I would like to say that the situation and background of the present applicant countries is quite different to that of the previous accessions, as recognised by the European Commission in its Opinions about the present applicants (5).

382. Despite the pre-accession agreement, the Phare operations and other measures, applicant countries are still far away of been close to the regulations and competitive realities of the EU's internal market. The private sector is still weak and must strengthen its present position. The conduct of the economic policy is still in a phase of transition.

383. Let me conclude with some recommendations to the new enlargement states, based on my experience in previous enlargements exercises, during which I was the Chief negotiator on the EC side for the negotiations with Finland.

384. First: time, education on EU's matters, prudence and involvement of private sector and citizens is necessary, during the whole process.

385. Second: realism. As the Commissioner Hans van den Broek - responsible for External Relations with Central and Eastern Europe, said:

386. "One thing that is true for all applicants, regardless of the progress they have made to date, is the Commission's resolve to support wholeheartedly their preparations for membership until the day they join 
the European Union (EU). When we speak about the accession process, we do not differentiate between "ins and outs" but rather between "ins and pre-ins". All the applicants will be brought progressively into the EU's activities. All will become Members of the EU. Nothing could be farther from the Commission's intentions that to draw new dividing lines across Europe. Differentiation in no way implies discrimination. Enlargement is in the interest both of the applicants and of the EU itself. The benefits to the EU will be enormous, not only in terms of stability and security, crucial though this is, but also in terms of prosperity. The applicant countries are important partners, in terms of trade and investment. A hundred million consumers with rising incomes are already giving a major boost to economic growth and development throughout Europe."

387. It seems to me that it is totally necessary to maintain "momentum" towards membership during all the process while such membership may not conclude quickly.

388. Towards this end the EU established in 1997 new guidelines for Phare operations for the benefit of the ten central and eastern European countries knocking on the EU's door and to create a partnership towards future integration. As such, it is an accession-driven exercise, in which the EU is trying to improve the links with applicants in sectors like transport, telecommunications, creation of standards for enhancing adaptation of the economics.

389. I do not believe that corresponding answers to the past enlargements are very relevant to the position of the new applicants but I can assure that the European Commission will be also committed to preserve and improve the EU system and will continue to avoid that an increase in the number of partners will make it harder for them to work together. The European Commission is working to prepare the way for enlargement, particularly towards the east European countries, but is also working in favour of a simultaneous preservation and improvement of the deepening and quality of the European Integration.

390. In this context only countries able to respect in full the present and future Acquis Communautaire can be accepted as a member of "a better" and "genuine" European Union. It must be hoped that States applying for membership to the EU will put pressure on the EU to deepen at the same time as it is expanding. 


\section{REFERENCES}

(1) Enlargement of the Community: General Consideration, Transitional period and Institutional Implications, and Economic and Sectoral Implications, BULLETIN EC 3-78 (Supplement 1-3). Commission of the European Communities, 1978.

(2) Europe and the Challenge of Enlargement, BULLETIN EC, Supplement 1/1992. Commission of the European Communities, 1992.

(3) Agenda 2000: 1. For a stronger and Wider Union and 2. The Challenge of Enlargement; Doc. COM(97)2000 final, Vols. I and II, 15 July 1997. Commission of the European Communities, 1997.

(4) F. Granell. "The First Enlargement Negotiations of the EU", pages 35-63 of J. Redmond (Editor), The 1995 Enlargement of the European Union, Aldershot, Ashgate, United Kingdom, 1997.

(5) Published by the European Commission in Supplements to the Bulletin of the European Union: Cyprus (5/1993), Hungary (6/1997), Poland (7/1997), Romania (8/1997), Slovakia (9/1997), Latvia (10/1997), Estonia (11/1997), Lithuania (12/1997), Bulgaria (13/1997), Czech Republic (14/1997) and Slovenia $(15 / 1997)$. 


\section{Chapter 6: Panel of Senior Negotiators: The Main Conclusions}

$$
\text { By Tony Verheijen }{ }^{32}
$$

32. Tony Verheijen is currently Administrator, Policy-Making, Co-ordination and Regulation, at SIGMA in Paris. $\mathrm{He}$ is on leave from his post as Lecturer in Public Administration and European Integration at the University of Limerick, Ireland. 


\section{Introduction}

391. One of the main purposes of the Athens multi-country meeting on European Integration and Public Administration Reform held in October 1997 was sharing experience. The panel of senior negotiators (in which the experience of States involved in previous rounds of enlargements was discussed with officials involved in the management of EU affairs in the countries of central and eastern Europe) was one of the most important elements of the Athens meeting. Three former senior negotiators, Byron Theodoropoulos, chief negotiator for Greece, Hans Brunmayr, chief negotiator for Austria and Vitor Martins, member of the negotiating team for Portugal, discussed their experience with the participants. This report summarises their main recommendations to the future negotiators of the countries of central and eastern Europe.

\section{Greece}

392. The main recommendations of Mr. Byron Theodoropoulos are provided in the table below. In his introduction $\mathrm{Mr}$ Theodoropoulos provided the background to the start of the negotiations with Greece. Greece decided to apply for EC membership after a long debate in the 1960s on whether Greece should attempt to join the EC or EFTA. The Greece perception was that the EC was a more promising organisation than EFTA, and in 1974 the decision was taken to submit a formal application for membership. One of the main motives for applying at that time was to try to consolidate the emerging democratic system of governance in Greece, by anchoring it firmly into the EC system. However, the difference in economic development between Greece and the EC posed a major problem. The European Commission proposed in its Opinion a five year pre-accession period before Greece could join the EC. However, the Council overturned the Commission Opinion and instead decided to open negotiations with Greece. The negotiations lasted some four years. The structure established for the negotiations consisted of a Minister for Community Affairs, who was assisted by an inter-ministerial secretariat at the Ministry of Foreign Affairs. The inter-ministerial secretariat was established for the specific purpose of co-ordinating the negotiation process. The negotiating team was appointed by the cabinet, but responsible to the Minister for Community Affairs. The mandate for the negotiations was approved by the Greek Parliament. Under the Greek Constitution it is possible to transfer sovereign rights to international organisations provided a 3/5 majority of the Members of Parliament vote in favour.

393. Byron Theodoropoulos, Ambassador of Greece (retired), was Head of the Greek Negotiating Team during the negotiations which lead to the accession of Greece to the then EEC. He offers, from his own experience, the following advice to those who may have to negotiate on behalf of candidate Members. 


\section{THE TEN POINTS OF THEODOROPOULOS}

\section{Realise from the start with whom you are negotiating.}

Candidates negotiate with the EU as a whole, not with the individual Member States. Member States certainly negotiate among themselves before arriving at an agreed position to be presented to the candidate, but once they have arrived at such a position, it represents the EU stand as a whole. There is, however, wide scope for informal contacts with individual Member States with the aim of promoting better understanding of the candidate's viewpoint.

\section{Be clear in your mind what you are negotiating about.}

You are not negotiating about revising existing treaties or other parts of the so-called acquis communautaire. You are negotiating about the timetable of the application of that acquis by your country, i.e. essentially about the length of various transitional periods before the EU laws are fully applied by the candidate or with regard to the candidate.

\section{Order your priorities.}

You will have to negotiate on a number of issues, some of which will be more important than others. Arrange in your mind their order of priority and relative importance so as not to lose time and negotiating power on secondary items.

\section{Keep in touch with the other candidates.}

They are not your rivals in securing favours from the EU. Each may have his own problems, but you are all striving towards the same objective. You can learn from them and they may learn from you. Good communication channels are essential to all.

\section{Watch your home front.}

This may prove your biggest headache. As a negotiator you depend on the information fed to you by the services back home. If it is insufficient or incorrect, your negotiating stance is weakened. But, you also depend on the instructions you receive from home. Your government may base these instructions on internal political considerations or on misconceptions about the EU. It may sometimes prove more difficult for you to negotiate with your government about the instructions they send you than to deal with the EU.

\section{Do not nourish too high expectations from accession; it may prove more costly than you think.}

The impact of accession may, on the whole, be a positive one. In certain cases, however, you may discover that it has adverse effects on this or that sector of your economy or that it may require more cost and effort from you to conform with accession standards.

7. Remember that restructuring your economy will have to be done anyway, not just for the sake of accession.

Constraints, efforts and sacrifices needed for this restructuring would have to be done under any circumstances to bring your economy into shape. Accession to the EU should not be used as an excuse in order to deflect the possible discontent caused by the increased effort.

\section{Estimate the relative importance of your simultaneous accession to the EU and NATO.}

The two accessions may pose diverging demands upon your economy. Accession to NATO may require considerable new expenditure for military infrastructure to satisfy NATO standards, while accession to the EU may, at the same time, need more expenditure on other sectors of your economic infrastructure. Neither NATO nor the EU will be able to cover this additional expenditure in full. You will have a hard time deciding where to spend your money.

\section{Be aware of the possible weak spots of the European construction.}

There are at least three "fault lines" in this construction which, if left unattended, may cause problems:

a) the distinction between the "big" and the "small" Members, where some will be more equal than others;

b) the gap between the economic power of the EU and the manifest weakness of its political will; and

c) the possible increase in the gap within European societies between social classes, if a strict monetary policy is applied.

10. We have no credible alternative other than positive, creative participation in the EU.

Increased efforts internally, weak spots in the European structure, a steep path ahead are realities to be reckoned with. Do not despair, do not get discouraged. This is a one-way road. We should all make our contribution to the march forward. 
394. The Austrian experience was presented by Mr. Hans Brunmayr, former Chief Negotiator for Austria. The upcoming negotiation process will start with the screening of the acquis. At the time of the Athens conference in October 1997, it was not yet clear whether the screening process would be done country by country, or in groups. The screening will be divided into chapters. The exact number of chapters and their subject matters can change for each new round of enlargement negotiations. The extent to which changes are made in the division of the acquis in chapters depends mostly on the development of the Union, in particular on whether significant new competencies have been transferred to Union level. The screening process requires the involvement of a large group of experts. Mr. Brunmayr stressed the importance of having a good co-ordinator of the screening process both "at home" and "in Brussels". It is important for the candidate states to start the screening process as early as possible, even before the formal start of the negotiations, and to seek clarification from the Commission when necessary. Contacts with the Commission are important in general; the Commission can help candidate states in trying to find solutions for problems and can act as a go-between with the Council. However, convincing the Commission does not mean that one has won the argument. Working with individual Member States can also be important, in particular if the Commission is unable to broker a compromise in COREPER.

395. The final rounds of negotiations will generally be highly political. In these final rounds, those issues will be addressed which cannot be resolved at expert level and that require ministerial decisions. In this phase, the candidate country will need a large team in Brussels to back up the negotiators. In the case of Austria, the experience which had been built up in negotiating the EEA agreement proved to be particularly useful for the management of this phase of the negotiations.

396. The "management" of the home front can at times be more difficult than the negotiations themselves. The coalition government made internal decision-making processes rather complicated; some form of balance between the different political interests had to be found on each issue. However, in the end, the final rounds of negotiations were handled by a small group of high-level politicians.

\section{Portugal}

397. The Portuguese experience was presented by Mr. Vitor Martins, who was responsible for industry, energy and external relations in the Portuguese negotiating team. After the accession of Greece, the Portuguese team sought a meeting with the Greek negotiators. Greece had just completed its accession negotiations when Portugal was at the point of starting its negotiations. The exchange of experience with Greece proved to be very useful.

398. The very fact that Portugal could start negotiating was of extreme psychological importance. It allowed the government to carry out much needed economic and also administrative reforms. Without the prospect of future EU membership, it would have been much more difficult to convince citizens and the administration to accept these reforms. In Mr. Martins view, it is therefore important to start the negotiations, even if it is clear from the beginning that the process can take a long time.

399. The most important points to take into account, based on the experience of Portugal, are:

1. Co-ordination is the key word. Without a well-functioning co-ordination system, nothing will work. The hard core of the co-ordination system should consist of the chief negotiator and his negotiation team. The chief negotiator should ensure the fusion between internal interests and external demands. In the case of Portugal, like in the other two cases, the internal interests were more difficult to satisfy than the external (EC) demands. Keeping the internal communication flow going is therefore extremely important. 
2. The chief negotiator should be a high profile person who enjoys broad political support. Preferably his/her nomination should be approved by parliament. The Portuguese Parliament did not give the chief negotiator a formal negotiation mandate. The negotiation team was totally independent of the parliament. One of the weak points of the Portuguese system was the weak communication flow to Parliament.

3. The core negotiating team should include both generalists, such as lawyers, economists, and general experts able to judge which issues are of vital importance to the country's interests, and area specialists. All members of the team should be highly qualified in EU affairs, both in theory and in practise; in particular since a large part of the negotiations will take place in "back corridors". The core negotiating team should be as small as possible, preferably no more than 15 people. It is also important that the negotiating team is a team in the real sense of the word, not a conglomerate of different interests.

4. It is important to ensure continuity, even if negotiations will last for 5-6 years. In the Portuguese case, the team remained almost the same, with only one or two exceptions.

5. It is important to invest in providing the Commission with information. One cannot assume that the Commission has adequate information on one's country. For instance, it took Portuguese negotiators a lot of time and effort to make DG VI aware of the fundamental differences in agricultural structures between Spain and Portugal. The initial reaction of the DG was to treat Spain and Portugal as if they had the same type of agricultural structure.

6. It is important to make a proper analysis of the impact of adopting the acquis and, on the basis of this analysis, to determine a realistic time schedule for narrowing the gap between the prevailing situation in the country and the requirements of EU membership. Once the national position on these issues is established, it is important to ensure a strong overall political commitment to this position.

\section{Discussion}

400. During the discussion a number of issues were addressed. The two issues which were discussed most extensively were the main problems experienced during the negotiations and the definition of the procedures for appointment of the negotiators and of their relations with government and parliament.

401. The discussion on the main problems during the negotiations was addressed both from the side of the EU and the candidate states. According to Francisco Grannell, who was a member of the Commission Enlargement Task Force for the negotiations with Austria, Sweden, Finland and Norway, the institutional issues were finally the most difficult to be resolved. This will again be a main stumbling block in the next round of enlargement. Neither the Ioannina compromise ${ }^{33}$, nor the IGC provided a solution for the institutional problems generated by the expansion of the number of Member States. For the side of the former candidate states, the two main issues raised were the difficulty of explaining specific national problems (such as agricultural structure, mentioned both for the case of Portugal and Austria) to the Commission and the Member States, and the problem of putting the final result of the negotiations in writing. In this respect, it is very important to have good lawyers on the team to ensure that what gets written into the Accession Treaty is really what has been agreed. The final text is drawn up jointly by legal experts from the Council, the Commission and the candidate state.

33. This is a complex compromise on weighted voting in Council meetings that was reached between EU leaders in Ioannina in June 1994 to allow for the 1995 enlargement. 
402. The other main issue which was discussed at length was the procedure for appointing the negotiating team and the negotiating strategy. In Portugal and Austria, the appointment of the chief negotiator was put to a parliamentary vote. The negotiating team was subsequently appointed by the chief negotiator. However, there was a significant difference between the countries regarding the extent to which parliament was informed and consulted during the negotiation process. Whereas in Austria, the Parliament was briefed and consulted on a regular basis during the whole negotiation process, the negotiating teams in Portugal and Greece operated in a much more independent way, reporting mostly to the government.

403. The exchange of experience between former negotiators and officials involved in the management of EU affairs in the candidate states was generally evaluated as one of the most useful aspects of the Athens meeting. The open and frank discussion of the main issues arising from previous rounds of negotiations provided the participants with an inside view of how the negotiation process operates. However, the discussion went beyond the discussion of negotiating procedures and strategies. The most important lesson to be learned from this debate might be the following: the strength of internal communication mechanisms and co-ordination structures in candidate states, and the ability of the candidate country to "educate" the EU about national specificity, are, in the end, more important in determining the result of the negotiations than shrewd negotiating tactics. 
PART III: PREPARING FOR JOINING THE EUROPEAN ADMINISTRATIVE SPACE

Chapter 7: Administrative Reform in the Commission Opinions Concerning the Accession of the Central and Eastern European Countries to the European Union

By Jacques Fournier ${ }^{34}$

34. Jacques Fournier is Senior Counsellor, Policy-Making, Co-ordination and Regulation, SIGMA. He is also Conseiller d'État, France and former Secretary-General of the French Government. 


\section{Introduction}

404. The following remarks are based on an analysis of Part B.1, "Political criteria", Part B.4, "Administrative capacity to apply the acquis", and Part C, "Summary and conclusion", of the Commission Opinions of 15 July 1997. These Opinions show clearly the importance that the Commission attaches to administrative reform, which it considers essential if these countries are to develop the capacity to apply the Community acquis in the medium term (Section 7.1). They also provide a number of elements that help describe the public administration "model" that the Commission has in mind (Section 7.2). Lastly, the assessments made in the Opinions indicate the broad lines of the administrative reform these countries need to carry out in order to facilitate their accession (Section 7.3).

\section{The Importance of Public Administration Issues in Commission Opinions}

405. For the first time, the Opinions devote considerable attention to issues of public administration. This is evident from the following:

406. the administrative capacity to apply the acquis is, together with political and economic criteria and the ability to assume the obligations of membership in the Union, one of the four dimensions of the review conducted by the Commission in the central part of its report. In all the Opinions, a special chapter (B4), which is always substantial, is devoted to this subject;

407. public administration issues are raised at a number of other points in these Opinions, in particular:

- in the section on political criteria, which describes the functioning of institutions and of the executive in particular and discusses the judicial system, local government and the civil service;

- in the section on the obligations of membership, financial questions and control mechanisms are discussed;

408. the need to continue and reinforce administrative reform is always referred to in the recommendations made in the conclusion.

\section{What Model for Public Institutions Emerges from the Opinions?}

409. The Commission bases its analysis on the decisions made at the Copenhagen (June 1993) and Madrid (December 1995) European Councils. These guidelines remain very general. As regards political criteria, the Copenhagen decision stated that countries should have "stable institutions guaranteeing democracy, the rule of law, human rights and respect for and protection of minorities". As regards public administration, the Madrid decision simply mentioned that the harmonious integration of CEECs into the European Union would require the "adjustment of their administrative structures". But a number of specific provisions of the Community acquis regarding the various sectors of government action specify the administrative structures to be implemented in certain fields.

410. On this basis, the Commission lays down in its Opinions a number of positive rules that it believes the countries should follow. Even when it does not prescribe rules, its criticisms often make it possible to deduce the changes it considers to be desirable. An overall model thus emerges which may be 
unevenly developed in certain areas but is far more specific that the general guidelines of the European Councils.

\subsection{Political Institutions}

411. This is the field in which the Commission goes furthest. In its view, democracy, the rule of law and respect for human rights presuppose that a whole series of conditions are met, and the Commission carefully checks that each country complies with the following requirements:

- free elections, which allow the alternation of power, and respect for the rights of the opposition;

- separation of powers, under which the different branches of government do not exceed their authority and co-operate with each other;

- an independent judiciary, which has the necessary authority and means to carry out its mission;

- some degree of local autonomy;

- the full range of political and civic rights (right of appeal, protection against arbitrary arrest, voting rights, freedom of association, freedom of expression, ownership rights, right to privacy, etc.) and economic, social and cultural rights (minimum income, trade union freedom, the right to strike, freedom of education and worship, etc.);

- an effective system for protecting minorities; this final point was discussed at length in the Opinions, given the size of minorities in a number of the countries concerned.

412. All these elements are assessed comprehensively, without favouring a specific approach to any of them. In particular, it should be mentioned that the Commission does not take a position on whether there should be a bicameral system in parliament or how many tiers of decentralisation would be desirable.

413. On the latter point, the Opinions observe that in a number of countries local autonomy has still not been established at regional level, although it is often on the policy agenda. The Commission makes no specific recommendation in this regard and merely urges that countries organise their levels of government as they see fit to ensure the application of European regional policy and to establish effective control of the use of the funds provided for this purpose.

414. Lastly, in the light of abuses under previous regimes, the Opinions attach considerable importance to the existence, in law and in practice, of control of the police and secret services, and to conditions in prisons and orphanages.

\subsection{Public Administration}

415. The Opinions do not provide a specific model for the organisation and functioning of public administrations. However, they do take more definite positions on certain aspects, and in particular on the civil service.

416. The structures of governments and administrations are described, but the Commission does not take a position as to their appropriateness, for example regarding the number and organisation of 
ministries. Nor does it address the role of the centre of government specifically, although this is mentioned for some countries. However, the existence of a body responsible for the interministerial co-ordination of European affairs, and special EU units inside ministries, is mentioned in several Opinions and is considered to be a positive step.

417. The decision-making process, whether this concerns the preparation of legislation and regulations or more generally the organisation of government deliberations, is not mentioned, apart from references to the desirability of effective co-ordination between ministries in a few Opinions.

418. The method of operation of the administration is not discussed either. In particular, there is no reference whatever to the ongoing debate between the "Weberian model" and "new public management" 35 in the field of administrative science. The most that can be said that is that the Commission implicitly refers to the "classical model" prevailing in most EU countries.

419. This is especially clear with regard to the civil service. This issue is mentioned in all the Opinions, and a number of definite positions in this regard may be deduced from the comments made:

- the Commission urges countries to pass an act dealing specifically with the civil service;

- it is implicitly but unmistakably in favour of a career civil service;

- it emphasises the need to ensure that the public administration is independent of the political authorities;

- it stresses the importance of training, especially in the fields covered by Community legislation;

- it implicitly favours bringing public sector pay into line with that in the private sector.

\section{3. $\quad$ Sectoral Policies}

420. Under the heading "key sectors for the application of the acquis", the Commission, in all its Opinions, reviews the current situation in a number of fields that it thinks are essential if future Member countries are to apply Community legislation effectively. In each of these fields, the Commission mentions specific requirements that give a clear idea of the public administration model it has in mind for a number of government departments.

421. The first requirement is very general. It concerns the judicial system, which must be sufficiently effective to ensure uniform enforcement of Community law in the country in question.

422. The discussions that follow are much more specific. The Commission defines the characteristics that certain administrative bodies should possess. We shall not describe these in detail here, but simply note that the following bodies are mentioned:

35. Editor's note: for a brief discussion of these models, see for example Innovations in Public Management: Perspectives from East and West Europe, edited by Tony Verheijen and David Coombes, 1998. This book defines the main problems facing public administrations in central and eastern European countries and provides a comparative evaluation of the relevance for these countries of reform measures undertaken in OECD Member countries. The publication is part of the New Horizons in Public Policy series, published by Edward Elgar Publishing, Cheltenham, United Kingdom. 
- the bodies responsible for ensuring the free circulation of goods (regulations, standardisation and certification) and services (in particular, banking, insurance and security transactions);

- the bodies responsible for monitoring competition;

- regulatory bodies for telecommunications;

- the departments dealing with indirect taxes;

- the bodies responsible for veterinary and plant health inspection and those that implement the CAP;

- the transport authorities;

- the departments responsible for health and safety at work and social affairs;

- the bodies responsible for the environment;

- consumer protection bodies;

- the administrations responsible for home affairs and justice, to the extent that they are in charge of the enforcement of immigration laws, border control and international police and judicial co-operation;

- customs;

- financial control, in particular to ensure the fight against fraud and the monitoring of the use of Community funds. In this regard, the Commission stresses the need to make a clear distinction between internal and external control and to strengthen the means for fighting transnational financial crime.

423. Consequently, the Community model of public institutions can be described as a "variable geometry" one, since it addresses the conditions of democracy relatively fully, but is fairly vague about the organisation of public administration as a whole, although it is more specific about the civil service and a number of sectoral administrations considered to be essential to the functioning of the European Union.

424. The next section of this paper addresses how the Commission appraises the current situation in the light of this model.

\section{How do the Commission Opinions Assess the Public Administration of Candidate Countries?}

425. The answer to this question is obviously of great importance since any shortcomings observed by the Commission will call for action during the pre-accession period. As we shall see below, the Commission's appraisal of public administration varies considerably from one field to another.

\subsection{Political Institutions}

426. The Commission's assessment is favourable on the whole, since seven of the ten countries are considered as already meeting the conditions laid down in Copenhagen. Two others (Bulgaria and Romania) are "on the way" to meeting these conditions. In only one country, Slovakia, is the situation considered to be unsatisfactory. 
427. At the same time, the Commission does make a number of recommendations on points where it feels improvements are necessary, such as freedom of speech, control over the police and secret services, or conditions in prisons.

428. The situation of minorities is considered to be satisfactory on the whole, although cases where improvement is needed are mentioned, particularly as regards the Russian-speaking population in the Baltic States, the Hungarian minority in Slovakia and gypsy populations in central and southern Europe.

\subsection{Justice}

429. The Commission does not arrive at specific conclusions in this field. After describing how the judicial system is organised in each country, it observes the same shortcomings in virtually all cases, in particular the fact that courts are overloaded and that judgements can be a long time in coming. It ascribes these shortcomings to the insufficient training of judges, who are often inexperienced, and to the quantity and complexity of the new legislation they have to enforce.

430. There are specific comments on the situation in some countries, for example, regarding the independence of judges in Slovakia, penal procedure in Bulgaria, the definition of the powers of the prosecutor-general in Lithuania and judicial control of prosecutors' activities in Romania.

431. For a number of countries (Bulgaria, Poland, Slovakia and Slovenia), the role played by the constitutional court or its equivalent is assessed favourably.

432. On the whole, the Commission remains highly circumspect in its evaluation of the ability of these countries' judicial systems to apply the Community acquis in the medium term. This assessment can be broken down into the following divisions:

- it is unable to assess the situation at all ("a definite evaluation at this stage is difficult") for Bulgaria, Romania and Slovakia;

- it questions the pace of the progress that remains to be made ("it is not yet possible to judge when the judicial system will acquire the capacity to play its role effectively") for the Czech Republic, Estonia and Lithuania;

- it states that there is a need for a "major, reinforced effort of reform" to make it possible to apply the acquis (Latvia);

- it says that there is a favourable outlook for achieving this capacity, provided that the effort under way continues (Hungary, Poland and Slovenia).

\subsection{Local Government}

433. The current situation in this field - all countries have local autonomy at the level of municipalities, but only some have an intermediate level between the municipal and central level - is described but not criticised.

434. However, the Commission stresses decentralised authorities' need for financial autonomy and mentions excessive financial dependence on central government in a number of countries (such as, Bulgaria, the Czech Republic, Poland and Romania). 


\subsection{Administrative Reform}

435. The Commission stresses that all countries need to design and implement a coherent overall plan of administrative reforms. It recommends that one country's government start work in this field (Bulgaria), approves of the fact that some countries have created a body responsible for designing and monitoring the implementation of reform (Hungary and Slovenia) and finds it unfortunate that there is no body of this kind in the Czech Republic.

436. In each case, the Commission observes whether the country has such a plan and is actually implementing it (Hungary, Lithuania, and Slovenia,) or has yet to develop one (Bulgaria, Czech Republic, Romania). It stresses the considerable effort already made in Poland, with the reform of the economic administration of the central government, in Estonia where a coherent plan for applying the Community acquis has now to be implemented, and in Latvia where, following the 1993 reforms, the new office responsible for public administration will have an important role to play.

\subsection{The Central Administration}

437. As regards administrative structures, the Commission only mentions the role of the centre of government twice, observing that it has developed in Estonia and that it is too weak in Slovakia, which slows down strategic decision-making. The Commission finds that in Bulgaria most ministries are in need of basic reform, while in Latvia the effectiveness and cohesiveness of the various ministries is highly uneven, and in Estonia they are considered to be too small and overloaded.

438. The administrative structures devoted to co-ordinating European affairs are on the whole looked on in a favourable light (Estonia, Latvia, Lithuania, Poland, Hungary, Romania and Slovenia). The Commission would like to see this kind of structure implemented in Bulgaria and strengthened in Latvia.

439. As regards procedures, it is recommended that Slovenia improve co-ordination procedures between ministries. In Romania civil servants show an unwillingness to assume responsibility, which means that decisions on many matters must be made at too high a level. In Bulgaria, there is a need for greater transparency in the handling of public affairs.

\subsection{Civil Service}

440. The Commission observes that few countries have specific legislation governing the civil service (Estonia, Hungary, Latvia, Poland). Slovenia has some legislation, but it does not provide a comprehensive legal basis for the civil service and a new act is being prepared. This is also the case in Slovakia. In Lithuania, an act was passed in 1995, but it is currently being amended. Elsewhere (Bulgaria, Czech Republic, and Romania) there is still no civil service act, although the new Romanian and Bulgarian governments plan to address this issue. The Commission Opinions stress the priority that should be given to this problem and emphasise how useful an act can be in setting out the rights and obligations of officials and ensuring their independence from the political authorities.

441. In this respect, the Commission observes that, except for some relatively high civil service positions for which officials may be chosen on the basis of political criteria, the independence of civil servants is at least partly safeguarded in a number of countries. But, there are still serious problems in this regard in Slovakia, Romania and Bulgaria. 
442. The Commission's assessment of the issue of the size of the civil service is quite balanced. It points out cases of overstaffing, particularly in routine jobs (Poland and Romania), but finds that overall staff numbers are adequate in Slovenia and Bulgaria. It also frequently observes that there is a relatively widespread shortage of staff, especially of skilled staff in certain departments that are essential for applying the Community acquis (Czech Republic, Estonia, Latvia, Poland and Slovenia). What is more, the Commission stresses the risks of across-the-board staff reductions that do not take into account the practical situation of the departments concerned (Hungary).

443. The Commission strongly emphasises the widespread need to improve civil servants' job skills and to launch appropriate training initiatives. This leitmotif runs through its assessments, both at a general level and in the specific sectors in which the acquis must be applied.

444. For training to be effective, excessive turnover must be avoided, particularly in skilled jobs. In this regard, the Commission observes that in virtually all countries there is a considerable gap between pay in the public and private sectors, although it does not recommend a specific solution to this problem. Slovenia is the only exception in this respect, for although there is a wage gap, it is felt to be small.

\section{7. $\quad$ Fighting Corruption}

445. The Commission frequently addresses the problem of corruption. It does so in its discussion of the civil service and finds that there is widespread corruption, which leads to highly critical attitudes on the part of the population. The Commission also mentions this problem in its discussions of the police and judicial system, which often prove to be powerless to fight crime, fraud and corruption.

446. This situation is found in all countries except Slovenia, where there is no evidence of significant corruption in the civil service.

447. The Commission makes recommendations in two of the fields mentioned above, i.e. improving the effectiveness of the judicial system and police and weeding out corruption in the civil service.

\subsection{Sectoral Administrations}

448. It is not possible to list all the assessments made for the ten countries in each of the twelve sectors examined by the Commission. A few general observations can be made here:

449. The Commission naturally tried to make a practical appraisal of the situation in each sector in each country, but it did not always have the necessary information. As a result there are general evaluations in a number of fields that are virtually identical across countries. For example, this is the case of:

- consumer protection, a field in which all countries are criticised in the same terms because of continuing confusion over the scope and goals of policies, a lack of qualified experts, poor organisation and the failure of the courts to take these issues seriously;

- indirect taxation, a field in which the Commission observes that it is difficult to assess the efficiency of departments across countries because of high staff turnover; the Commission also recommends improving the rules governing staff, training and pay.

450. The staffing criterion is considered important by the Commission, and whenever it can it gives the numbers working in every department that it mentions and always assesses whether they are adequate 
or not. In these cases, the Commission fairly often recommends increasing staff, whether for financial departments (internal revenue service, customs, financial control) or for those departments responsible for enforcing the rules of the single market and competition (supervision of banks and insurance, monitoring competition, regulating communications and transport, etc.) or in charge of applying social, environmental or consumer protection legislation. More generally, it stresses the need to develop the expertise of the civil servants working in these departments or agencies.

451. The Commission also observes that in some fields, beyond these problems of staffing and job skills, governments simply do not have the necessary institutional framework to implement Community policies, particularly in the administrative and financial spheres. Consequently, it recommends that the necessary regulatory and administrative measures be adopted. This is fairly often the case regarding the application of the Common Agricultural Policy and regional policy. But the Commission also recommends adjustments or improvements in the regulatory framework in other fields, such as telecommunications, transport or the environment.

452. On the whole, criticism far outweighs compliments in the Commission's review of sectoral situations, and the conclusion most often reached is that further efforts are required. There are, however, some exceptions:

- for the departments responsible for the free circulation of goods and services and for competition, the situation is considered to be satisfactory in the Czech Republic, Hungary and Poland, and to a lesser extent in Slovenia;

- transport safety is a matter for concern for all countries, with the exception of Slovenia;

- it is generally recommended that health and safety at work be reinforced, but the situation in Hungary and to a lesser extent Poland is considered to be satisfactory;

- for home affairs and justice, the Czech Republic, Estonia and Slovenia and were assessed favourably.

\subsection{Overall Assessment of Administrative Capacity}

453. In the summary, assessment of the various countries' administrative capacity to apply the Community acquis in the medium term given at the end of its Opinions, the Commission has to encapsulate the findings of its reviews in a single sentence. It is of interest to compare these brief assessments since they show the fine distinctions drawn by the Commission. For example, although the Commission recommends that all countries continue the process of administrative reform, it can be noted that:

- it considers that four of them are likely to have the capacity to apply the Community acquis in the medium term. But to do so they will have to continue their effort of reform, which must be "comprehensive" in Slovenia and Poland and "substantial" in Slovakia (no adjective is used to describe the situation in Hungary);

- the Commission presents the capacity of the six other countries to apply the acquis only as a possibility. It will take an effort of reform that is described as "significant and sustained" (Czech Republic), "major" (Estonia), "major and sustained" (Bulgaria and Romania) and "major and reinforced" (Latvia and Lithuania). 


\section{Chapter 8: Governance and European Integration — Reliable Public Administration}

By Jacques Fournier ${ }^{36}$

36. Jacques Fournier is Senior Counsellor, Policy-Making, Co-ordination and Regulation, SIGMA. He is also Conseiller d'État, France, and former Secretary-General of the French Government. 


\section{Introduction}

454. The quality of public administration, its reliability and reform, are at the front line of the transition and integration processes on which central and eastern European States are embarked. The Netherlands government has targeted governance as a central issue for its Presidency which precedes the opening of negotiations (under the UK Presidency foreseen for end of March 1998) with the candidate states.

455. How are problems of public administration to be considered in light of European Union laws and practices? What are the specific needs of central and eastern European countries? How can the European Union help find solutions? How can governance be introduced into the accession negotiations?

456. This paper draws on the experience of the SIGMA Programme which has been working on administrative reform with the EU candidate countries since 1992.

\section{Europe and Governance: The European Administrative Space}

457. The issue of governance is central to building Europe, which is first and foremost an institutional structure. The institutions created for the European Union - its Parliament, Council of Ministers, Commission, Courts of Justice and Accounts - are not substitutes for national institutions. Rather, national and EU institutions work together and depend on each other.

458. Under this system, national public administrations play a very important role. They are responsible for implementing and controlling execution of European Community policies in all of the European Union States on behalf of their respective governments. While the EU has a central administration, it does not have external agencies. It depends on national governments for the implementation of its directives and regulations. And because of rules such as mutual recognition, each Member government depends on the quality of execution of community policy by its partners in order to fulfil its own domestic responsibilities.

459. Increasingly, domestic and foreign policy of the Members is settled in a European context. Whatever decision-making rules are agreed during the IGC, the ability of the Union to develop policy will continue to depend on the ability of each of its Members to participate effectively in policy discussions.

460. Governance in Europe is characterised by mutual dependence which is most keenly felt at the administrative level. It might therefore be expected that the European Union would require Member States to abide by certain basic rules concerning the organisation and operation of their public administrations. But this is not the case. The Treaty of Rome contains no provision of general application to public administration. No General Directive has been adopted. In other words, apart from some rare instances when Community provisions require Member States to have certain forms of organisation (e.g. in connection with the promotion of competition in services of general economic interest, pursuant to Article 90 of the Treaty) there are no Community rules regarding public management. In keeping with the principle of subsidiarity, national administration is the responsibility of national governments.

461. Despite the relative absence of direct powers, the European Union does influence how Member States govern themselves. 
462. For one thing, the Union imposes on its Members obligations expressed in terms of results to be achieved (what is referred to legally as an "obligation de résultat"). States are free to set up their public administration as they please, but it must operate in such a way as to ensure that Community tasks are effectively and properly fulfilled to achieve policy outcomes which are set by the Union.

463. On this basis, the Union is entitled to demand that current or future Member States have a reliable system of governance, able among other things to promptly incorporate Community standards and decisions into their legal systems, effectively implement such standards and decisions within their borders, and ensure enforcement through the appropriate means of control and procedures for settling disputes.

464. It also has the right to demand that Members are able to maintain consistency between their domestic policies and Union policies as they evolve over time. Simple compliance with Community law at a given time is not sufficient. The countries in question must also be able to progress along with the rest of Europe, including in the areas of economic growth and its social repercussions.

465. The Union is dominated by the objective of economic integration. European companies are increasingly acting on a European, or world-wide, rather than a national stage. If economic efficiency and reduction of transaction costs lead to consideration of a common currency, they just as inevitably lead economic agents to press for common standards in the administrative and regulatory framework under which they operate. And companies are just as dependent as governments on the effective working of the mutual recognition process to sell their products abroad and rely on quality assurance of the products they import.

466. What may be called a "European administrative space" is gradually taking shape. In order to implement Community decisions, the public servants of Member States meet frequently. They get to know each other and trade views and experiences. Patterns of communication develop which have an impact on decision-making, so that common solutions are often found. Officials and experts from European States are becoming used to examining issues jointly, including those having to do with public administration. A European administrative space is emerging with its own traditions which build on but surpass the distinctive administrative traditions of the Union. Administrative reliability, which is necessary for the rule of law, effective implementation of policy and economic development, is one of the key characteristics of this space.

467. All of this evidently presupposes a well-performing public administration. Administrative capabilities and how these are to be evaluated are likely to be issues behind the formal process of negotiation for accession.

\section{The Special Needs of Central and Eastern European Countries in Terms of Public Administration: Guiding Transition, Fulfilling the Obligations of Membership}

468. Since 1989, central and eastern European countries have been involved in a fundamental transition consisting of three parts:

- introducing democracy and democratic State institutions;

- shifting to a market system; and

- moving toward integration into the European Union. 
469. Each of these changes carries significant implications for public administration which is reflected in a brief discussion of sectors and systems.

\subsection{Democracy}

470. Initially, democratisation meant establishing new constitutional provisions transferring power to elected representatives, laws protecting freedom of opinion and expression, the establishment of a multi-party system and the possibility for the electorate to replace those in power. By and large these steps have by now been completed in the candidate countries.

471. However, democracy also requires the creation of a legally constituted state, acting under the rule of law and with the elimination of arbitrary use of public power. It therefore presupposes a thorough transformation of the system of governance; government is no longer at the service of a party or class. Public administration must represent the permanence, continuity and regularity of the State, as well as implement the policies of the government in power. Administration is not only neutral execution of policy; it is also a constitutional safeguard. Civil servants must be protected from partisan influences. Impartial control procedures must be introduced. Channels must be opened for interaction with the public at large. Authority must be decentralised.

\subsection{Market}

472. A market economy requires that individual initiative be given primacy, but that it be set in a legal and administrative framework. Apart from the spontaneous creation of new enterprises, it involves the privatisation of many firms and the enactment of new rules governing business and industrial relations. This process is well on its way in most countries, but far from complete. The share of the private sector in the economy of all candidate countries is constantly growing through privatisation and growth of spontaneous entrepreneurial activity. This also has considerable significance for public administration.

473. Firstly, the role of government has to change. It must move away from direct production of goods and services. This requires wholesale transformation of the duties, structures and personnel of national public administrations and their regional agencies. The economic role of government is still vital. The competitiveness of the private sector (essential precondition for European integration), depends on the reliability, efficiency and effectiveness of the public sector. But the State needs goods and services for its own purposes. A large investment is needed to create new laws, administrative structures, skills, and human capital to carry out public procurement in compliance with international and European standards.

474. Secondly, the transition to a market economy requires dismantling obsolete institutions and initially implies a reduction in output. This in turn has the effect of increasing unemployment and income disparity, which places new types of tasks on administrations and places them in a different relation with citizens. Citizens and enterprises need, and are legally entitled to, administrative services, but the culture of public service, the clarity of entitlements, the execution of administrative acts under law, and the systems of control and redress are not always present. Public servants are given power, but the frameworks to control its use are weak.

475. Thirdly, macro-economic balances must be maintained and budget resources allocated to priority purposes. This is in itself an administrative task for which past experience has not prepared the budget systems. In addition, the balance, and the tax burden, depend on the efficiency with which public resources are used. 
476. In order to manage these processes, governments must have reliable information, be willing to pay attention to the needs of populations and have the ability to negotiate with major international financial institutions. To handle such tasks, they must rely on skilled, professional, competent public administration.

\subsection{Integration}

477. Integration into the European Union can only occur if democratic systems of governance and market economies are in place. Integration complements and reinforces these through a major political project which involves both governments and all leading political and social forces. This process is now under way and can be considered irreversible, but it, too, adds constraints and tasks onto already over-burdened public administrations.

478. Such is the nature of policy-making in and for Europe that future Members must be able to deal with European issues by involving their entire government. They must have efficient co-ordinating institutions. They must integrate, within a relatively short period of time, the entire acquis communautaire. And they must be able to implement effectively Community directives and policies in their domestic contexts. Candidate countries have established central co-ordinating units to accomplish these objectives.

479. Their special situation of transition means that the accession burden on candidates from central and eastern Europe is far greater than for other candidates or previous entrants. Compared to Austria, Finland or Sweden, they have to travel a greater distance from their starting position to achieve the conditions that will make membership possible. Compared to the situation when Greece, Portugal and Spain joined, the acquis is significantly larger and is still expanding.

480. In the Member States of the Union, both national administrative systems and the acquis communautaire have evolved over decades in line with the growing sophistication and complexity of Western European economies, their integration into the European and world trading systems, and their multi-layered market systems and infrastructures. The economies of central and eastern Europe, for so long held back in forced, relative simplicity and geographically distorted, will take time to evolve.

481. Without challenging the policy objectives of the acquis or of integration, it is certain that the costs of implementing the acquis in central and eastern Europe will be high. Although they may have to be paid anyway as the price of economic transition, the timing, extent and distribution of the costs will be affected by the integration process. The costs will depend in part on how well systems of governance can design national policy instruments to meet current and future needs, without allowing laws to move too far ahead of the capacities of administration to implement them and of private actors to comply with them.

\subsection{Sectors and systems}

482. The issue of administration for integration is usually expressed in terms of compliance and enforcement capacities in individual sectoral areas - for example, regulations and inspectorates to enforce European standards of health and safety at work. These are part of the acquis and compliance will be closely monitored not only by bureaucrats but also by Western companies eager to avoid "unfair" competition. However, the "European Administrative Space" is more than this; it is about how administrative systems work, i.e. their general qualities of reliability, predictability, certainty, efficiency, due process, transparency, ability to challenge, etc. A sectoral approach to administrative reform - 
creating a health and safety inspectorate - is necessary but not sufficient. General, cross-governmental administrative systems, such as personnel management, policy-making, general procedural standards, control and redress mechanisms, need to be redesigned. But, as noted above, apart from the general criteria of democracy and rule of law (cf the "Copenhagen criteria") and the "obligation de résultat," such issues are not treated in the acquis communautaire.

483. Public administration has a key role to play in all of these changes. It is at the same time both a principal actor and object of change. Its reform must be given priority. But what kind of reform and with what objectives? How can the European Union be of help?

\section{A Possible Contribution by Europe to Administrative Reform in Central and Eastern European Countries: Incentives and Models Rather than Coercion}

484. Given the interdependence of governments of Member States, it is in the interests of all current Members that future Members are "administratively competent". In central and eastern Europe, the capacity to satisfy the "obligation de résultat" referred to above cannot be considered to have been completed. Much progress must still be achieved in order to secure accession. But administrative reform, which must fundamentally upset existing arrangements, is typically resisted. Administrative reform in the context of transition is also profoundly difficult - even more so than in the countries of Western Europe. Resources and skills are scarce. The European ambition is both a lever and powerful incentive for national governments in central and eastern Europe to bring about change.

485. The position of the Commission on the eve of the opening of negotiations for accession reinforces this message. In a recent Information Note on "New Policy Guidelines for the Phare Programme in the Framework Of Pre-Accession Assistance" (24 March 1997), it insisted on the importance of the issue: "The institutional and administrative capacity of the candidate countries is a key problem in the preparations for enlargement," the text reads. It implies that incorporating the acquis will not be enough. Candidates will need to "develop the public services required to implement Community rules with the same guarantee of effectiveness as in the Member States".

486. Based on this observation, the Commission indicates that institution-building will henceforth be one of the two main priorities of its Phare Programme. In addition, measures undertaken as part of its programme of support will no longer be driven by "demand" but by "accession" and reflect the need to implement Community acquis. A very clear link has thus been established between the process of accession to Europe and administrative reform. Administrative reform is clearly not limited to sectoral institutions and procedures, but covers the systems of governance.

487. But how can this link be translated into practical measures? What administrative-reform objectives should central and eastern European countries pursue in order to secure accession to the European Union as promptly as possible? How can choices be made among those objectives? What should be the sequencing?

488. These are crucial questions at a time when negotiations for membership are about to begin. However, the absence of acquis communautaire in terms of public administration makes it impossible to provide direct answers to them.

489. The European Union is not enabled to force its own solutions on candidate Members any more than it can impose them on its own Member States, except in certain special areas governed by specific 
Community regulations. Moreover, even if it could enforce its ideas about the content of administrative reform it would face three difficulties:

- administrative reform is fundamentally a political decision of sovereign States;

- it can only be designed and carried out with full knowledge and understanding of the local circumstances;

- it must be supported or "owned" by the people who have to carry it out.

490. The Commission recognises this and, in its Information Note, states that "through institution-building projects, Phare will help candidate countries to reinforce democratic institutions, the rule of law, their public administration and auditing bodies". The Note continues "If institution-building is to be effective, it will be necessary to increase the involvement of Member States...[and develop].. relations between present and future Member States".

491. Must one stop there? It would be in the interest of neither the Union nor the candidates for accession. Both are in need of more detailed and more practical basic standards than the general notion of the ability to live up to Community commitments. Candidate countries should be in a position to set concrete goals and priorities.

492. This is where the concept of a European administrative space becomes useful. Europe is not entitled to set conditions for future Members to which current Members are not subject and which they would find unacceptable. But Europe is fully justified in suggesting alternative models to serve as possible reform objectives.

493. In other words, the institutions and practices of leading modern democracies, in particular among the current Members of the European Union, could provide relatively easily the basic standards to which candidate countries could aspire and the Union could agree. These institutions and practices could guide shared understanding of the reforms which should be carried out.

494. It is true that the constitutional and administrative systems of Member States differ considerably. At least two or three organisational and operating models exist on matters such as the separation of powers, government structures, regional decentralisation or federalism, the civil service system, the judiciary, etc. Yet these systems also share many features. A few basic principles of governance have proved effective and have become relatively widely accepted. They form something akin to a common institutional base which countries could legitimately use as a reference point for administrative reform, when seeking to consolidate democracy, rule of law and the market system.

495. This is in fact how things are done in practice. Since 1989, central and eastern European countries have turned for inspiration to European Union and OECD Member States for examples and models of the new institutions they need. This process does not impose obligations on candidate States but rather provides them with examples and incentives.

496. Experience has shown that European Union Member States have created certain institutions and adopted operating rules in order to implement common policies democratically and efficiently. These rely on a common base of administrative principles and cross-governmental (or "horizontal") systems. The practical steps taken in various countries are not exactly the same, but all have certain features in common. An attempt could be made to list those features which seem most important, in the context of accession, for the reforms undertaken by candidate countries. 
497. The list which follows is a first attempt. It is an indicative list only and is not official. It includes a number of key factors which the governance systems of EU Member States have in common and which seem worth considering given the current situation of public administration in central and eastern European countries.

498. A few comments are in order concerning the list:

- It refers to objectives which have not necessarily been uniformly achieved in countries which are already EU Members.

- It includes only "horizontal" features, leaving aside sectoral aspects which are also important.

- The organisational and operational principles cited have been described in such a way that they are at once sufficiently specific and sufficiently broad: sufficiently specific to make it possible to define concrete measures for achieving them; sufficiently broad to cover the full range of possible solutions from which every country can select those which are the most suitable to its particular situation, culture and current needs. 


\section{Indicative List of Key Common Factors Found in Public Administration Systems of European Union Member States}

\begin{tabular}{|c|c|}
\hline 1. & Central Organisation and Decision-Making \\
\hline & $\begin{array}{l}\text { 1.1 a constitution guaranteeing the right of the people to replace those in power, the separation } \\
\text { of powers, and the rule of law; } \\
\text { a government organisation providing for effective co-ordination among the ministries and } \\
\text { a sound link with budgeting, giving the Prime Minister sufficient authority to assume the } \\
\text { political leadership of the country; } \\
1.3 \text { procedures to ensure a co-ordinated policy-making and implementing process including } \\
\text { procedures for producing laws and regulations, ensuring that these are proper from a legal } \\
\text { and technical standpoint and making it possible to assess their financial, economic and } \\
\text { social impact; } \\
1.4 \text { an organisation of ministries whereby Ministers and policy staffs are freed from } \\
\text { day-to-day implementation of policies and can instead concentrate on devising policies, } \\
\text { drafting statutes and overseeing their implementation; } \\
\text { a public sector which, in the areas in which it operates, is given specific tasks to fulfil with } \\
\text { a degree of management autonomy, within the framework of clearly laid out legal } \\
\text { structures. }\end{array}$ \\
\hline 2. & Territorial Administration, and Relations with Citizens and Economic Actors \\
\hline & 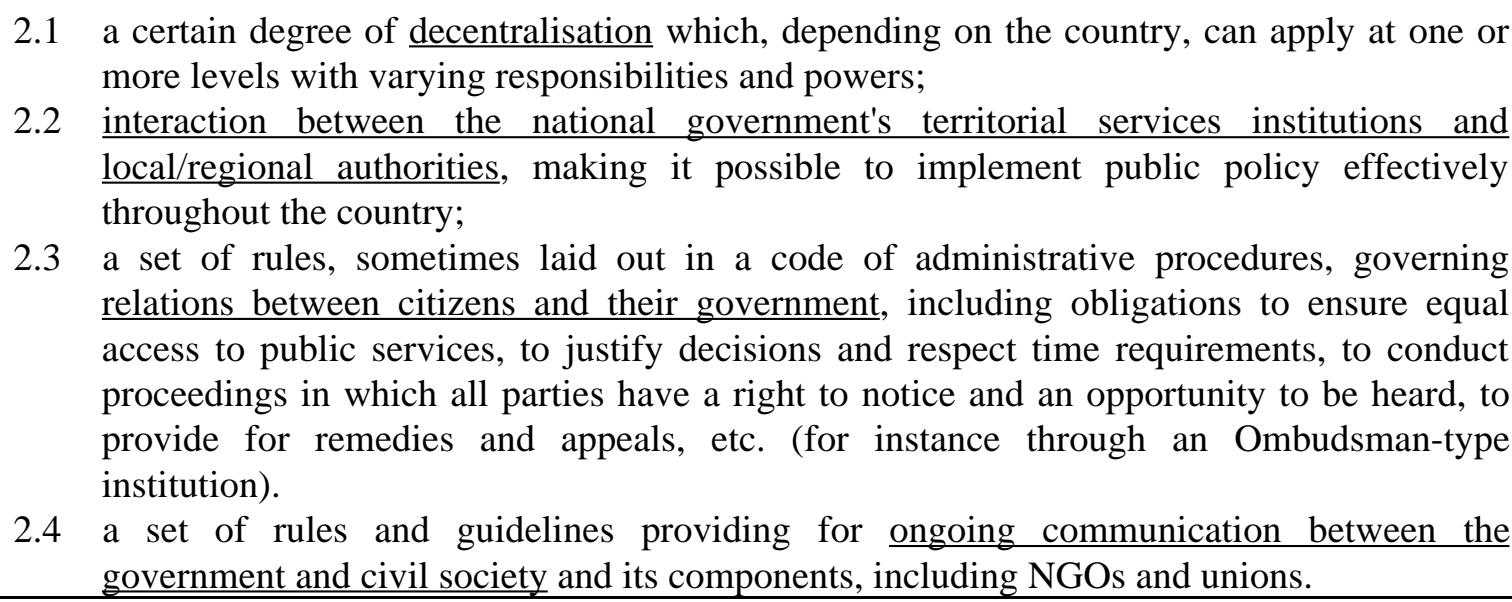 \\
\hline 3. & Means of Action and Control \\
\hline & 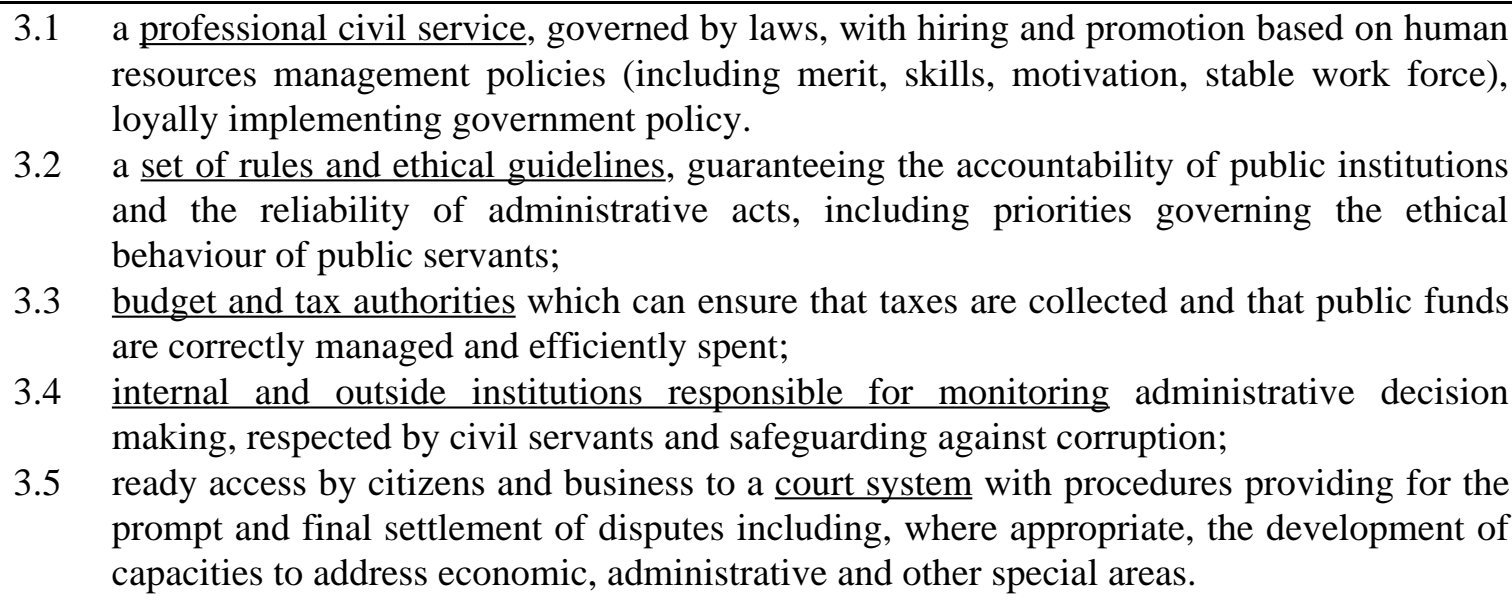 \\
\hline
\end{tabular}


499. Taking the above as points of reference and examining each of them thoroughly would probably make it possible to evaluate the existing situation and to establish goals and an order of priorities for measures to be carried out prior to accession.

500. However, the nature of these reference points has an important impact on the way in which this list should be used. Negotiation on these issues should not be based on constraint, but on shared understandings and goals.

501. Here again, reference may be made to the recent Commission Information Note. The "Accession Partnership", which it is proposing to set up between the Union and candidate States, certainly corresponds to this idea of the appropriate relationship for jointly engaging in administrative reform.

\section{Actions and Problems: Some Examples}

502. How far have things moved along the road described above? It is beyond the scope of this paper to review all reforms under way in all ten countries concerned.

503. We shall instead limit our remarks to some general observations about "horizontal" issues of governance which are particularly relevant to the notion of administrative reliability.

504. Our remarks concern first the administrative reform process as a whole, then the central organisation and decision-making in government, and finally the means of action and control.

\subsection{The Administrative Reform Process as a Whole}

505. It must be pointed out that the process is already well under way. Most of the candidate countries have created institutions responsible for planning and implementing administrative reform, and practical measures have already been taken in certain areas. For example, many laws have been enacted and regulations drafted, including on the organisation of work at the governmental level, the status of civil servants, government purchasing practices, etc. At the same time, all countries have set up a body responsible for European issues, in charge among other things of preparing the implementation of the acquis communautaire and, thereby, also involved in administrative reform.

506. Considerable interaction has developed with Member States of the European Union and the OECD, either bilaterally or multilaterally. Many co-operation projects have been conducted or are in progress, in particular as part of the Phare Programme, which is clearly the central tool for providing assistance, and is designed to act as a catalyst for aid initiatives.

507. Yet, much progress unquestionably still needs to be made, especially with respect to effective implementation and monitoring of decisions.

508. Among the issues which must be answered are how to generate tax revenue, enforce laws on public health or the environment, issue administrative permits needed by business, and provide ways for citizens to obtain information and appeal decisions. Answers are still far from having been found to these and other practical questions.

509. Experience from many countries shows that administrative reform is a time-consuming process. It requires material and human resources which are often cruelly lacking. It presupposes changes in attitudes and cultural transformations which can only be achieved very gradually. Although administrative 
reform is very technical, it has important political consequences. What can be done to facilitate the process? Three prerequisites seem essential.

510. The first is the existence of a political will. Administrative reform is a thankless task. It runs into many obstacles and its benefits become evident only with time. In order to be completed, it must have the strong and continuous backing of politicians. This in turn means that it is best for the authority responsible for the planning and oversight of reforms to be located as closely as possible to the centre of government (prime minister or council of ministers), and that a consensus must be sought on this topic so as to at least partially protect reforms from policy revisions resulting from changes in government. Latvia is a good example where administrative reform progressed because of strong political will. But, the abolition of the administrative reform ministry has slowed down this effort, which the government is attempting to relaunch today.

511. The second prerequisite is that planning and implementation of administrative reform be approached in an all-encompassing manner. Ten separate reforms, however well planned, do not amount to a general reform if they are not based on the same principles and carried out in a co-ordinated fashion. There is a need for an overall strategy. Regardless of the quality of available international assistance, a comprehensive vision can come only from the country concerned. Each country must set up organisations and processes to enable it to generate and pursue its own vision. Only with that vision will measures carried out as part of various programmes be co-ordinated and complementary, rather than incompatible, as is sometimes the case. Several countries developed comprehensive public administration reform strategies (e.g. Bulgaria, Hungary, Lithuania and Slovenia) which were sometimes thwarted by political cycles.

512. The third condition, perhaps the most debatable but also one which, from experience, we consider necessary, is that careful consideration should be given to risks involved in skipping any steps. Some European Union Member States, as well as other OECD Members, are currently experimenting with contracting out public management or introducing market-type mechanisms which add flexibility to the traditional operating rules of their public administration. Such innovations should be examined and discussed and may well be productive in countries which already have a sound administrative system. When applied in countries where the government system is still being assembled, they might have detrimental consequences, or the necessary conditions (e.g. information) may not be in place.

\subsection{The Government, National Public Administration, Centralised Decision-Making}

513. A sound central decision-making structure is of course essential for steering transition. This structure deals with a wide range of issues and operates at the frontier between the constitutional, political and administrative fields. A major transformation is taking place in this area.

514. Under the former system, the government did not really function as a collegial body and merely carried out decisions. The central committee of the single party decided upon policies. Ministers were responsible for implementing these policies in firms within their fields of jurisdiction.

515. The top and the bottom of this decision-making ladder have disappeared or are about to do so now. The central committee has ceased to exist. Most state firms are scheduled to be privatised. Between the two, a new type of government has to take hold, one in which national policies are debated among equals, ministers are no longer simple managers, but planners and regulators under the leadership of a prime minister who has to choose among alternatives and steer effectively the ship of State. 
516. Poland has set an example in this area, as it has launched a thorough restructuring of its state-sector administration. In 1996, an important step was taken with the enactment of a dozen new laws. They concern chiefly the reorganisation of the central government administration, the strengthening of the role of the prime minister, the redefining of the tasks of ministries, the consolidation of share-ownership in public-sector firms and the transfer of authority to regional authorities (voivodes). Many institutions have disappeared, or been transformed or created as part of these measures.

517. Problems arising in this connection are either of a political and constitutional nature or of an administrative and technical type.

518. The former concern the separation of powers. Some central and eastern European countries have created parliamentary systems in which chambers of deputies have considerable authority and use this authority often to legislate in greater depth and breadth than their equivalents in European Member States. Furthermore, the widespread adoption of proportional representation has often lead to a certain fragmentation of political forces and coalition government further encouraging parliaments to take greater legislative initiative. Under these circumstances, the question being raised in many countries is whether it would not be advisable, in the name of more efficient decision-making and of the implementation of reforms, to change somewhat the balance of power between the legislative and the executive and, within the executive, to give the prime minister more authority. Member States of the Union have their own differing experiences and ways of handling these matters, which it may be useful to examine.

519. At a more technical level, procedures have been developed in all countries for governmental co-ordination and drafting of laws and regulations. Yet not all problems have been resolved, including those having to do with the collection and dissemination of information, the legal contents of statutes and their impact, or the links between public policies and budgets. Exchanges of experiences which bring together officials from candidate countries with their counterparts from EU Member States can be very fruitful. The SIGMA Programme promotes such exchanges, e.g. on links between budgets and public policies, regulatory impact assessment, impact of accession on national audit institutions. Also, an organisation such as the Network of Institutes and School of Public Administration in central and eastern Europe (NISPAcee) brings together academics and public servants to exchange information on advances in public administration in the region.

\subsection{Means of Action and Control}

520. This section deals specifically with the civil service, the management of public funds, and controls - three areas which are addressed by the SIGMA Programme. However, it must be underscored that reforms undertaken in these three areas seek to address the same concerns, namely:

- making the rule of law a reality through the adoption of clear regulations on the exercise of authority, the use of public funds and their control;

- making administrative measures efficient so as to enable the government to properly fulfil its duties during the transitional period.

\section{The Status, Role and Conduct of Civil Servants}

521. This is obviously a key issue. The new policies adopted by the region's countries will bring results only if a body of experienced and motivated civil servants exists to plan and implement them. Fortunately, in every country, a great number of public employees meet those criteria. Yet it is evident that they are often put in particularly difficult and precarious positions. 
522. Under the former system, no specific rules governed the hiring and employment of government workers, who were covered by general labour legislation. The situation remains unchanged in certain countries (e.g. Czech Republic, Slovakia). Throughout the region, whatever the legal status, it is often the case that civil servants do not enjoy job security, are not protected from politically-motivated decisions and, given the government's limited financial resources, generally earn less than their counterparts in the private sector. As a result, they lack motivation, turnover is very high and there is a tendency to seek outside income and to be more vulnerable to corruption.

523. In these circumstances, it would seem that the creation of a professional civil service would be a key objective, for several reasons.

524. Civil servants are invested with the authority of the government and disburse public funds. Their authority and the means at their disposal are ultimately defined and granted by the parliament. Clear responsibilities must be established for those who are invested with that authority and use those funds, and mechanisms must exist to monitor their performance.

525. A basic reason for creating a civil service system is to establish the status of those to whom the authority of the government is delegated, define their duties and accountability as well as their rights and protection against unwarranted pressure. This is a key element of democratic reforms.

526. At the same time, economic and institutional reforms and the preparations for accession require that the government administration has access to considerable legal and technical expertise. A competent civil service is not just an instrument for drafting policies and laws but also for enforcing them.

527. Another very important reason for having a civil service is to make it possible to acquire qualifications and experience and to maintain continued staffing by career civil servants in all of the fields where reform takes place. It is a particularly productive long-term investment.

528. A well-designed and ably-managed civil service is a guarantee of reliability, professionalism, impartiality and continuity in governance. It makes it possible to meet quality standards and to monitor results in all administrative sectors and levels. Unlike systems where employment is governed by labour codes, a civil service promotes co-operation and communication within central government and between it and the various public agencies. It also contributes to the qualitative checks and balances of the State.

529. In 1992, Hungary became the first country after the revolutions to start along this road. Since then, other countries have followed suit, such as Estonia and Latvia. Poland enacted a new civil service law in 1996 to modernise the 1982 law and is about to start progressively putting it into practice. The new government of Romania considers this a priority. However, in general, budget restrictions block the implementation of new legislation, while cultural and political traditions remain hard to overcome.

530. Many issues remain to be resolved. They concern, among other things:

- the choice of legal status for government employees and the respective role played by the notions of jobs and careers; who will enjoy this status (whether it should cover only senior civil service officials or all government employees);

- policies to be adopted concerning the relationship between civil servants and politics, including the defining of positions for which appointments may be based on political considerations;

- policies to ensure compatibility of staffing of different branches and levels of government; 
- policies and financial means to make a civil service career attractive;

- approaches to be used with respect to codes of conduct and to prevent corruption;

- technical issues concerning administrative systems and methods.

\section{The Management of Public Funds}

531. Here too, the transition to democracy and the market system has been creating major problems for central and eastern European countries, causing them to make drastic changes from the way things used to be done.

532. A new government accounting and financial management system has to be developed, reflecting the new nature of the relationship which now exists between government and economic entities or individuals. The system must:

- correspond to fundamental democratic principles such as those of parliamentary oversight of the budget drafting and implementation process, equal assessment of taxes and distribution of government assistance, and control over the proper use of public funds;

- define a clear relationship between government and private sector enterprises where the private sector is associated with the delivery of public services;

- provide government with effective control over public finances, in particular the collecting of taxes, the level of spending and the balancing of budgets;

- create a mechanism for making choices between competing priorities for public expenditure in order to attain greater efficiency, effectiveness and economy in the delivery of public services.

533. These objectives may be achieved by strengthening the organisation of the ministry of finance. In the previous system, the ministry's role was essentially one of accountancy. It held an almost secondary role in the governmental and administrative systems. Without going from one extreme to the other, we can say that from the perspective of fulfilling the State's new market economy role, it must strengthen not only its attributions, but also the quality of its human resources.

534. In this way an important objective can be achieved when the time comes to open membership negotiations i.e. the establishment of trust between the financial administrations of the different countries and the Commission's departments.

535. In some countries, considerable progress has been made in this area. A new legal framework has been developed. Laws on budgets and on public spending have been enacted. Financial control practices through internal and independent audits have been strengthened.

536. Requests by the countries for co-operation in this area are becoming more specific and technical, which is a sign of progress. However, they are far from having found solutions to all problems. The serious financial crises faced recently by some countries provide further confirmation. The issues of concern include:

- the financial relationship of the government to state-owned firms and financial oversight of those firms;

- control over the growth of the informal sector; 
- management of the relationship between central budgets and local ones;

- management and oversight of social expenditures;

- management of government capital investments.

\section{$\underline{\text { Control and Appeal Mechanisms }}$}

537. As accession comes closer to becoming a reality, the matter of controls over public administration and of procedures for appealing its decisions tends to become more important. For the internal market to operate soundly, it is not sufficient to adopt provisions at the central level. Decisions made must also be put into practice on a daily basis, new regulations must be enforced throughout the land and an opportunity must exist to seek appeal mechanisms.

538. Community law frequently refers to the notion of equivalence between the standards and procedures applicable in various countries. For this principle to apply, government and control bodies must operate in a relatively uniform manner throughout Europe.

539. In this connection, everything that has to do with internal administrative controls, ombudsman and mediation functions, audit and oversight of government spending or the settlement of administrative disputes will be given priority in reforms over the coming years. The fact that community funding will go into infrastructure projects, which will be largely administered and controlled by the countries themselves, will lend urgency to reforms in this area.

540. The fundamental concept here is that of a legally constituted state. It means that the right to create ministries, departments and agencies must be defined in law, that the powers and obligations of State institutions should be clearly established by law and that they must, if their actions are questioned, answer to the law. It also means that the relationship between the citizen and the administration must not depend on the goodwill of its civil servants but must be governed by law. Lastly, it means that each ministry or agency must undergo examination and controls by other institutions or authorities whether they be of a legal or non-legal nature.

541. The countries in the region are at very different stages of development of law and administrative procedures. But they all have a long way to go, even in countries such as Hungary and Poland which have a long tradition in this domain which remained in place during the communist period. But other countries are only just beginning. In addition, there is a certain degree of contradiction between the procedures put in place during the communist period and those which are suitable for a democratic, legally constituted state. This contradiction is apparent in the countries which adopted codes of procedure during the communist period and which have simply modified them with a view to adapting them to the new requirements. This amendment approach ensures continuity and progressive adjustment but it may be that the principles of the two periods are so different that a complete re-write must be envisaged.

542. As for the procedures, the degrees of development of legal and non-legal controls of the administration vary considerably from one country to another. The most appropriate method of control of content and merits of administrative action is the subject of discussions, and varying views are expressed on this. The ombudsman system has been adopted in several countries and seems to work well. However, its capacity is limited and it has not been implemented everywhere.

543. Central audit institutions or courts of account have been set up in many countries. But the norms essential to external audit concerning independence and the range of controls, such as those established by 
INTOSAI ${ }^{37}$ and adopted by countries in the Union, are not always provided for, and even less applied in practice.

544. The accent is placed on the role of inspections and special commissions and a vast network of parliamentary special committees has been created. In general, these organisations are only beginning to function as a form of control of administration. One general problem is that the role, responsibilities and resources of these control bodies seem to be often badly defined, which results in cross-checking or excessive limitations. Lastly, while most countries have entrusted the public prosecutor with public action duties, his role is not always clearly defined, especially at a time when we are witnessing citizens' increasing recourse to legal controls.

545. To use public resources more efficiently, a strict financial control is needed which reduces the probability of fraud, waste or corruption. Such a control is also necessary to establish relations of trust between the taxpayer and the administration, and between the Union and the government. The quality of management controls and internal financial administration varies, not only between countries, but also between ministries and other organisations. It is, of course, equally true of the countries in the Union but to a lesser degree. Article 209a of the Maastricht Treaty and the declaration of the European Council of Madrid in December 1995 laid down an initiative on this point, the importance of which we cannot stress enough.

546. A solid financial control cannot be established in a modern State by external audits only, even if these are of the utmost importance. The basic structure is still made up of procedural and ethical norms of the administration itself.

547. It is evident that many questions remain on the points raised above and in particular, the following:

- How to ensure a balance between the concept of an efficient government with a large degree of decentralisation and the necessity of having strict financial and performance controls;

- How, to establish institutions and control mechanisms, as well as how to make them function effectively in practice;

- How to ensure the effective independence of the control institutions;

- How to develop and maintain the required abilities and qualifications;

- How to establish more trust between citizens and the political system.

\section{Conclusions}

548. As the Netherlands Inter-Governmental Conference draws to a close and at a time when negotiations for membership are about to start, the following points need to be emphasised:

549. Pursuing public administration reform is necessary to consolidate transition. But the pursuit of the European integration objective changes the content, timing, sequencing and significance of administrative reforms.

37. International Organisation of Supreme Audit Institutions. 
550. Accession to the European Union is governed by the Copenhagen criteria which include democracy, rule of law, and competitive economies. Public administration is fundamental to each of these, but there is only an indirect legal base and little practical possibility to impose norms especially for "horizontal" governance.

551. Effective national systems of government are necessary for the proper functioning of the Union. It is in the interests of all parties - candidate countries, current Members and the European Institutions - that public administration in central and eastern Europe be upgraded, at least to come close to the standards of reliability of current Member States. On the basis of this shared interest, negotiations can be started and aid programmes developed.

552. In order to successfully conclude the negotiations, the Commission needs reliable, competent counterpart institutions, benchmarks and yardsticks. The countries need a clear understanding of what is expected of them.

553. But there are no given solutions, and no fixed points. Both Europe and national systems of administration are constantly evolving. Each central and eastern European country has to find its own way forward and chase a rapidly-moving target of performance standards.

554. The only practical way forward is to reach a shared understanding of goals based on common public administration principles and practices of modern, democratic countries. These should serve as a reference to conduct assessments and reach decisions in this area. Aid should then be used to arrange for countries to have access to the rich and diverse experience of Member States. 
CCNM/SIGMA/PUMA(98)39

Chapter 9: EU Integration and Civil Service Reform

By Jacques Ziller ${ }^{38}$

38. Jacques Ziller is Professor of Public Law at the University of Paris I (Sorbonne). 


\section{Introduction}

555. This paper aims to clarify the rationale for developing the quality of a professional civil service in the perspective of integration to the European Union. It tries to explain why the European Commission may consider having a right to assess the quality of an administration and also tries to present features common to current EU civil services which could be used by the Commission as standards for the assessment of civil services in candidate states.

556. Since 1957 and the signature of the Treaties of Rome, the guiding principle of European integration has been, as stated in the Preamble of the EEC treaty, and later on in Article A of the Maastricht Treaty on European Union, to create "an ever closer union among the peoples of Europe". As the case law of the European Court of Justice (ECJ) shows, this is more than a philosophical statement. It is the guiding principle of a process of approximation of the economic, social and even political systems of the Members of the Union. Approximation does not mean harmonisation: there is neither a project nor a need for having identical systems and institutions throughout the Union. Approximation means that EU Members look more and more at each other and find a source of inspiration for reforms in successes and failures of their neighbours. As demonstrated in the legal sphere with the concept of "general legal principles common to Member States' which has become an important source of the case law of the ECJ, a set of standards common to EU Members exists and is developing in the fields of law, institutions and economy. Becoming a Member State of the Union means accepting those general standards as features relating to the acquis communautaire which is constituted not only by the Treaties, but mainly by all existing European Community (EC) legislation, case law and policies.

557. This is why EU Members' standards in matter of democracy, the rule of law and market economy are bound to have an impact on civil services of new EU Members. It also means that they will be at the background of a possible assessment of their civil services by the Commission, comparing them to some extent with the civil services of present EU Members. Even if civil services were not to be on the official agenda of negotiations, an assessment of the existing systems and reforms to be undertaken could be linked with the negotiations for accession. CEECs will be looked at as future Member States, having to comply with all obligations of any EU Member, and failures in the administrative system could slow down the negotiating process.

558. After having explained why the EU would asses the civil service system of a candidate to integration, the paper examines the impact on civil services of EU Member and candidate states' general standards and presents the general characteristics of the civil service systems of current EU Members.

\section{Why Would the EU Assess the Civil Service System of a Candidate to Integration?}

559. Since 1995, it has become clear that the quality of work done by public administration is a matter of concern of the EU in the framework of a possible accession of CEECs to the Union. Furthermore, although the organisation of civil services remains clearly the sole responsibility of Member States, a growing number of legal provisions and principles of EC law have an impact on civil services. This may justify the EU institutions in trying to monitor or even to assess the organisation and functioning of civil service systems of EU Members and candidates to membership. 


\subsection{CEECs Integration to the $E U$}

560. The White paper on "preparation of the associated countries of Central and Eastern Europe for integration into the internal market of the Union", of May 1995 already indicated that the Commission will look not only at the "paper work" done on adapting legislation, but also at the capabilities for implementation of common policies and enforcement of EC law in candidate states. The paper particularly insisted on the "Conditions necessary to implement and enforce legislation":

561. "3.25. The main challenge for the associated countries in taking over internal market legislation lies not in the approximation of their legal texts, but in adapting their administrative machinery and their societies to the conditions necessary to make the legislation work. This is a complex process requiring the creation or adaptation of the necessary institutions and structures, involving fundamental changes in the responsibilities of both the national administrative and judicial systems and the emerging private sector...."

562. "3.26 The presence of the necessary enforcing authorities is crucial to provide certainty of other Members of the Community that legislation is properly implemented. The proper operation of these administrative, judicial or private sector structures in turn depends on training and education facilities for the personnel concerned...."

563. The Commission's Opinions (Avis) about the candidatures of CEECs to the EU of July 1997 generally underline the weaknesses of these countries' public administrations and sometimes the lack of a civil service law. This has clearly to be read in the light of the approach developed in the White paper.

564. Following this approach, it seems logical that the Commission might try to assess the administrative structures and the civil services of candidate countries, however, this would be a quite unprecedented exercise compared with the preceding negotiations for accession or association. On one hand no assessment of existing administrative systems has been done during the preparation of the accessions of 1973, 1980, 1986 and 1995. On the other hand, the experience with the CEECs, be it the preparation of association treaties or the structured dialogue, are only partly relevant to the negotiations for accession. It has to be stressed that the Commission has only the power to make recommendations to participant governments and its influence is merely due to its capabilities to look for the Union's common interest and capacities to assess the development of negotiations. This means both that the Commission will have probably more freedom of expression and less influence on the outcome of the negotiations than experienced until now in the relations between the Union and CEECs.

565. The Commission's role is certainly to stress the objectives of integration on the side of the EU: making clear what are the implications of not only the internal market, but also the entire acquis communautaire. Upon this basis, it could try and find out what are the objectives of candidate governments in the matter of reforms they want to achieve in view of accession. Contents and time schedules could be produced by national administrations. The Commission could also try to get an independent expert assessment of the existing systems of civil service of candidate governments, in order to try and determine its capacity of adaptation. In these assessments, the Commission should mainly look at coherence in the way the problems are approached and identify obstacles (internal as well as external) to reform, in order to get an opinion about the possibilities of reform by "muddling through" and the necessities of positive intervention and technical assistance. Priorities and alternative strategies should be the main focus of reform projects, as well as trying to foster the interest of the population and businesses in administrative reform. 
566. It is important not to take existing civil services of EU Members (or elsewhere in the world) as models, nor to rely on the production of regulatory instruments, be they legally binding or of a recommendatory kind. The stress should be on studying existing and developing practices within civil services and looking at outputs of public administration in sectoral fields in order to compare it with different levels of productivity and compliance with legal principles in different EU Members. The purpose of an assessment of civil services, would be to check whether their structure and functioning are appropriate to reach the objectives of the Union.

\subsection{Legal Foundations in the EU Treaties}

567. Both the EU institutions (i.e. mainly the Commission and Court of Justice, but also Parliament, Council and not to be forgotten, the Court of Auditors) and other EU Members may be legitimately concerned with the organisation and functioning of the civil service of a Member State as far as they affect the proper functioning of the Community, the Union and their policies.

568. The clearest basis therefore is Article 5 of the EC Treaty, whereby "Member States shall take all appropriate measures, whether general or particular, to ensure fulfilment of the obligations arising out of this Treaty or resulting from action taken by the institutions of the Community...". The ECJ has made clear that this article was the basis of a Community control of the methods of implementation of EC directives. It has particularly stressed that internal administrative provisions are not sufficient for this purpose and that legally binding instruments have to be adopted by EU Members.

569. Article 209A - added to the EC treaty by the Maastricht Treaty - provides for action against fraud injuring the Community's financial interests. It stipulates that EU Members take the same measures against fraud whether it affects their own or the Community's financial interests. It provides also for co-ordination in order to protect the Community's financial interests, through a tight and regular collaboration between the competent services of their administrations. Although the scope of this provision is more narrow than that of Article 5, it is particularly important, be it only because it is the first consecration by European treaties of the concept of administrative co-operation. As the German example shows, this principle can become a basis for many obligations having a direct impact on the functioning of national civil services such as the exchange of information and personnel or co-ordination of administrative procedures.

570. Declaration No. 19 about the application of Community law, annexed to the Maastricht Treaty, whilst acknowledging that each EU Member is in charge of deciding the ways and means it finds most appropriate to the enforcement of community law, insists on the fact that community law has to be enforced at least as well as national law by Member States.

571. A last type of treaty-provisions could justify an assessment of civil services in order to check their adequation to the principles of democracy and the rule of law: Article F of the Maastricht treaty provides that government systems of Member States are founded upon the democratic principles and that the Union respects the fundamental rights as warranted by the European convention on the safeguard of human rights and fundamental liberties and as they result from constitutional traditions common to Member States. 


\subsection{Foundations in EC Law and Policies}

572. The implementation of the great majority EC directives and regulations is based on a good execution of their provisions by EU Members' administrations. According to the treaties, this has to be checked by the Commission and eventually by the ECJ on the basis of Article 169 EC treaty which provides for a specific procedure which stresses the role of the Commission as a "guardian of the treaties". Furthermore Article 177 of the EC treaty provides for a system of preliminary rulings upon the interpretation of EC law and upon the validity of EC directives, regulations and decisions, which in practice amounts to a possibility for any interested persons to bring a case before the ECJ. This is often used by businesses or individuals in order to fight their national legislation and bureaucracies, and can lead to a condemnation of the relevant Member State by the Court. This in turn can lead to the necessity to reform national legislation or reorganise public administration, as shown by the cases concerning access of foreigners to national civil services.

573. The scope for an impact of EC law on national civil services through these mechanisms is constantly growing. Three fields of importance have to be particularly mentioned:

- all aspects of the control of alleged discriminations according to national origins in the framework of the freedom of circulation of persons, goods, services and capital;

- directives on public procurements;

- competition law enabling control on direct or indirect subsidies to the private sector.

574. Whereas the two latter fields mainly have an impact on the working methods of the civil service and the organisation and functioning of ministerial departments, agencies, field services and local authorities, the first has a constantly deeper direct impact on the organisation and law of national civil services. The relevant cases are a perfect illustration of the ways and means by which EC law and institutions broaden their influence on matters which seem at first sight out of their scope.

575. Whereas Article 48(4) of the EC Treaty provides that freedom of movement of workers should not apply to "employment in public administration", a very difficult problem of interpretation of the EC Treaty appeared in the late seventies: was a Member State free to define the scope of "employment in [its] public service" - usually through the legislation on civil service - and thus reduce the field of application of the principle of free movement of workers, in order for instance to try and combat unemployment by reserving some sectors to nationals? The Court answered this question in a decision of 17 December 1980 (case 149/79, Commission v. Belgium). It stated that, for the purpose of reserving a post to nationals, "employment in public administration" had to be defined as employment "characteristic of the specific activities of public administration" as implying the "exercise of powers of public law and safeguarding the general interests of the state" or local authorities.

576. This Court decision has been the starting point of a series of reforms in the civil service laws of EU Members: most of them decided to open to non nationals the posts and careers which, to their understanding, did not imply the exercise of specific public law powers or the safeguard of public interest, while only a minority of EU Members considered that their existing legislation already was complying with the criteria set by the Court. Generally speaking, it seems that 60 to 90 per cent of public service jobs in Member States are nowadays open to citizens of all Member States of the Union. This was greatly due to persistent action by the Commission through negotiation with Member States and sometimes court procedures. 
577. This change concerning the citizenship condition for access to certain jobs in the public service is inducing a series of other consequences for the civil service which generally were not foreseen. The first consequence is the obligation to proceed to a classification of jobs and careers in order to determine whether they should be opened up or not. Then a series of steps have to be taken in order to ensure mutual recognition of qualifications and professional experience in public services, which can lead to a reappraisal of existing systems of training and mobility. Furthermore possibilities have to be created for international mobility of civil servants within the Union: this has an impact on the organisation of secondments, social security and pension schemes.

578. There are no general EU wide provisions about the civil service in the form of directives, regulations, or even non binding community instruments such as "white (or other colour) papers", yet the impact of EC law on civil service law is growing.

\section{The Impact on Civil Services of EU Member States' General Standards}

579. In broad terms standards on democracy, on the Rule of Law, and on market economy have an impact on Member States' civil services.

\subsection{Democracy and Neutrality of the Civil Service}

580. The impact of democracy on the civil service is quite important: starting with the principle of equal access on merit it extends to provisions on citizenship as a condition for participation in the service, special provisions for ethnical and cultural minorities in those countries where they are recognised, but also in the transparency of personnel management, the quality of appeal procedures and institutions as well as, last but not least, neutrality of the civil service.

581. Neutrality is an essential value of modern civil services and especially of the civil services of EU Member States. This is probably due to the fact that present day standards about neutrality have been developed after centuries of efforts to shape democratic civil services. It implies a set of standards in attitudes towards the public, which mean that neither personal relations, nor political, religious or philosophical opinions, nor obviously ethnical, gender or other differences may be taken into account by civil servants in their office.

582. In the framework of the EU, neutrality of the civil service is particularly important. It is absolutely necessary to enforce the prohibition of discriminations on grounds of nationality formulated in Article 6 EC Treaty. Less directly, it is also indispensable that national civil servants leave aside their personal opinions - or the opinions of their preferred political party - relating to European integration when applying EC law.

583. Neutrality means that even if cases of favouritism in the action of individual civil servants are revealed in practice, they are unanimously condemned. It is at the centre of the ethics of civil service. The best illustration probably of the importance of the standards of neutrality lies in the fact that even if a certain degree of politicisation of careers or even recruitments exists in some EU Members like Austria, Belgium or Germany - where it is strongly criticised in public opinion - this type of politicisation never leads to a politicisation of attitudes towards the public.

584. Standards of neutrality are however difficult to specify in abstract terms, as neutrality often has to be combined with accountability to elected politicians. In Westminster type democracies like the 
British Isles, France since the end of the fifties or Spain, politicians and civil servants have developed an understanding of the importance of neutrality through the succession of political parties in government and opposition. In consociational type democracies like Austria, Belgium or the Netherlands, neutrality is more the result of mutual supervision of political parties, which sometimes goes through the channel of politicisation of careers or even recruitment in order to ensure the representativity of the civil service. For this reason it is very important to dissociate in the assessment of neutrality between politicisation of the civil service internally and towards the public.

585. Breaches in neutrality towards the public nowadays mainly result from corruption, which has to be fought very strongly. Developments over recent years show an increase of revealed cases of corruption in a number of EU countries. It is difficult to say whether this means that corruption is increasing as such or that rejection of corruption in public opinion is strongly developing. In any case it means that neutrality of the civil service has to be more than ever at the centre of systems, rules and procedures relating to the civil service.

\subsection{The Rule of Law as a Foundation of Modern Administration}

586. The EC has often be called a "legal community" (Communauté de droit - Rechtsgemeinschaft) with reference to the "legal state" (Etat de droit-Rechtsstaat) which is the continental translation of the "Rule of Law". In modern societies based on the Rule of Law there is a growing need for predictability and equity in the way the civil service deals with citizens and businesses. This is one of the main reasons for professionalisation of the civil service, one of the common features of weberian and post-weberian administrations.

587. In the framework of the EC, it is to be stressed that legal integration has been brought much further than other forms of integration, both under the regulatory action of Commission and Council and under the pressure of ECJ case law. New developments in the framework of co-operation in matters of justice and internal affairs can only develop this aspect even more. This is why all aspects which relate the civil service to the Rule of Law have to be specially taken care of. It means that the civil service should not function as a network of personal, social, party-political or even nationality-bound relationships, but as a system of implementation of procedures related to clearly stated objectives and of enforcement of legally binding rules. This is one of the main reasons for having a special set of rules for the civil service.

588. Together with professionalisation of the civil service, the Rule of Law implies the existence, functioning and development of several different types of controls over the civil service. In all EU Member States internal control of the civil service is probably the most important - even though it is often neglected in literature. The main instrument of internal control is traditionally hierarchy, but in the framework of modernisation of public administration there is an important effort to reduce the distance between officials dealing with the public or the files and the top of the hierarchy, and to replace permanent ex-ante detailed interventions of the hierarchy by occasional ex-post evaluation based on objectives and outputs.

589. A specific form of internal control, only generalised in France and Spain, taking the form of specialised civil service careers - inspection "corps" - possibly could be fostered in the framework of common policies. There is also a tendency of developing audit - not only in the financial sphere - by either specialised public institutions like Courts of Auditors which co-operate more and more with one another and with the European Court of Auditors in Luxembourg, or by private auditing firms. 
590. In all EU Members, judicial control of the civil service is developing. Judicial review of administrative action by specialised administrative courts (according to a tradition common to France, Germany and other countries like for instance Sweden) or by ordinary courts (according to another tradition common to the British Isles and Denmark) is more and more developed, and there is a move towards approximation of administrative law of EU Members, mainly based on exchanges of information between judges, the legal profession and academics. The influence of EC law on national administrative law is steadily growing. This movement greatly contributes to develop the aspects linked to the Rule of Law in organisation and functioning of the civil services. There is also a growing tendency to control the civil service by means of criminal law and personal liability of civil servants; this instrument of control only present in Sweden since the beginning of the 19th century and for many decades is growingly used and also reinforces the priority of legality over hierarchy within the administration.

591. Last but not least extra-judicial control of the civil service is developing: most EU Member States have installed an ombudsman type institution, mainly to intervene quickly and in a flexible way in cases of maladministration where there is not a breach of law or where judicial action appears inappropriate.

\subsection{Public Management in a Market Economy}

592. Even if the second and third pillars ${ }^{39}$ of the EU are developing and if the acquis communautaire is not confined to the internal market but includes also a growing number of common policies, the internal market will probably for long remain the nucleus of European integration. Therefore the impact of market economy on the work, organisation and functioning of the civil service is not only due to increase, but also in a way which will be more and more common to different EU Members. Exchange of information and experience between civil services is constantly growing and more and more procedures and ways of dealing with a policy are developed in common by national and European civil servants.

593. The importance of a good civil service in international competition is nowadays recognised by governments and international organisations and particularly by the European institutions. Whereas many economists still tend to compare mainly the weight of public expenditure, a more comprehensive approach also takes account of the quality of civil service. Improving this quality in the view of avoiding mismanagement and raise service orientation and efficiency is seen as one way of creating competitive advantages of European countries in order to attract foreign investment and to help national businesses. In the framework of the EC, this will over years become one the main instruments for national government to help business, as it is one of the rare actions which cannot be considered as an "aid granted by State" which are forbidden by Article 92 and followings of the EC Treaty.

\subsection{The Impact of Accession and Participation in the EU on Member States'Civil Services}

594. Accession to the EU will have an impact on the civil services of candidates and new EU Members not only because of the consequences attached to belonging to the group of EU states who share a common approach to values such as democracy, the Rule of Law and market economy. It will have a more direct impact in at least three areas where careful and early preparation is needed.

39. Second pillar policies concern common foreign and security policy; third pillar policies concern justice and home affairs. 
595. Civil services of candidate states will have to prepare for all aspects of free movement of labour forces within the public service, with the possible exception of a limited number of functions. They will have to establish precise and detailed criteria in order to determine clearly which positions or careers in the civil service they want to keep for their own nationals. They will have to create systems for the mutual recognition of professional qualifications - even for positions and careers reserved to nationals as the latter will have the right to study in foreign countries. For those positions open to non-nationals, they will have to decide whether special procedures should apply to foreigners - in order to avoid the possibility of discriminations - or not, and make sure that a system of judicial control will be open to candidates to the civil service.

596. They will also have to adapt their system of lateral mobility, of promotion, of social protection and of retirement for the civil service to a possible mobility with other EU Members' and European institutions' civil services. As these are aspects where the acquis communautaire is still very limited, they should insist in participating in the EC mutual information process between civil services - amongst others in meetings of the ministers in charge of the civil service - as soon as negotiations for enlargement start. This means that responsibility to deal with those aspects has to be very quickly allocated within the civil service.

597. Last but not least, training for participation in the decision making process and the implementation of EC directives, regulations and programmes has to be fostered and accelerated especially in the framework of technical assistance.

\subsection{The Impact of Traditions and Civil Service Reform}

598. Whilst there is a tendency to approximation between the civil services of EU Members to which candidate governments have to comply with, important differences remain between the civil services of different EU Members - even the oldest ones as the Benelux countries, France, Germany and Italy mainly due to the impact of differing national traditions and differences in the pace and priorities of ongoing civil service reform. This obviously will also have to apply to candidate governments.

599. In the framework of an assessment, the standards for comparison probably will be high: it will not be possible to use existing failures in EU Members in order to argue that the EU could cope with poorly organised civil services; on the contrary, experiences of previous accession negotiations will probably lead several EU Members to adopt a much stricter attitude than they did in some of the previous occasions. On the other hand a too rigid attitude could be seen as a disguised way to hamper negotiations.

600. The solution of this dilemma has to follow three directions:

- For some aspects, mainly those relating to the free movement of labour in the public sector, transition periods will probably be laid down in the accession treaties. They should be linked to a set of criteria which could be used as reform objectives with timetables;

- For other aspects the stress should be laid on technical assistance during the negotiation period and after. Successful experiences in the eighties and nineties with amongst others the structural funds could be used in this context;

- More generally a boarder line should be drawn in discussions between the Commission, EU Member governments and candidate governments in order to determine what the objectives of European integration, and more specifically the objectives of EU and EC require in matter of civil service standards. 


\section{Characteristics of Civil Service Systems in EU Member States}

601. This section tries to outline the aspects which should be dealt with in approaching civil service reform in the framework of EU integration. It provides concrete illustrations from different EU Member States. They are not to be seen as prescriptions but as examples for comparison and as possible sources of inspiration.

\subsection{Definition of the Civil Service}

602. There is no definition of the civil service common to all EU Members of the EU. There are common purposes, but with different solutions. The main questions are whether government employees have to be submitted to ordinary civil- and labour law legislation or to a specific set of rules possibly under control of specific courts - "administrative" or "civil service" courts —, and whether the rules applying to these personnel should be homogeneous or differentiated. The reasons for these questions are to be found in constitutional provisions relating to the civil service, which usually reflect broader concepts about democratic accountable government. These concepts can be linked to the necessity of providing for the quality of staffing, continuity and stability of government employees, and specific obligations linked to the exercise of public authority, spending public money and so on.

603. In all EU Members a number of government employees are submitted to a set of specific rules, different from the usual contractual work relationship: they are usually defined as civil servants, fonctionnaires, Beamte, public servants (in Ireland) etc. So defined, the scope of the civil service varies greatly from one country to another.

604. In a majority of EU Members, including such different countries as Greece, France, Ireland the Netherlands or Sweden, government employees - be they employed by central government or local authorities - normally are civil servants, with possible exceptions for temporary employment, which often is also governed by special public law rules. In a more limited number of countries only a part of permanent government employees are civil servants. In Germany, there is a traditional distinction between positions related to public authority, which are reserved to civil servants by constitutional principles (about 40 per cent of government employment), and other functions which may be fulfilled by personnel under private and labour law. In Great Britain, the traditional distinction is between local government employees, submitted to ordinary labour law and civil servants, i. e. national government employees submitted to rules adopted by the executive under the "royal prerogative". Some countries are changing from one model to the other like Denmark over the last thirty years or Italy with a radical reform of 1993: nowadays only a few thousand higher officials in Italy are submitted to a specific civil service legislation, all others being employed by government on the basis of civil law contracts.

605. Whatever the overall choice is, there is room for more specific regulation of groups of civil servants or aspects of government employment. In France a distinction is made between state civil servants, employed by national government, "territorial civil servants" employed by local and regional authorities, and the "hospital civil service". In Germany the federation and each of the 16 Länder all have their own civil service law, but the latter comply with a general federal framework law on the civil service. In Italy most aspects of employment of government personnel are regulated by civil law and collective bargaining, but recruitment by competitive examination (concorso) being a constitutional principle is submitted to regulation by law.

606. Special attention has to be given to the difference between civil service and political functions. Elected officials and officials directly responsible to parliament are not considered as civil servants: they 
are either members of parliament and government or heads of autonomous administrative authorities. The case of employees directly selected and appointed by ministers is somewhat more difficult. The most common solution is that permanent positions are filled by civil servants even if they have a special legal position enabling government to hire and fire them at discretion: this is the case of top ministerial jobs in France (emplois à discrétion du gouvernement) and in Germany (politische Beamte) to the difference of Great Britain where traditionally the neutrality of the civil service means that even permanent secretaries are considered as totally neutral civil servants. Non permanent positions like special counsellors to the minister or members of "cabinets" - as they exist in Belgium, France or the European Commission are usually considered as political appointments to which civil service rules don't apply. In France for instance this does not preclude civil servants being seconded to such political jobs.

607. EC law has no direct impact on the definition of EU Members' civil services. The ECJ case law on Article 48(4) only applies to the question of nationality as a condition of access to the civil service. Although the Commission communication of 1988 considers education as one of the sectors to be opened to foreigners, it never asked Member States to change the nature of their employment: in a majority of countries like Belgium, France, Germany, Ireland or Spain, teachers of public institutions (schools and universities) are considered as civil servants, even often representing more than half of the total of civil servants. Nevertheless, they obviously have specific conditions of employment within the general civil service framework, be it only in matters of working hours and holidays. Furthermore in all countries where judges are considered as civil servants, they are placed under specific legal rules guaranteeing their independence.

\subsection{Legal Sources}

608. Legal sources of civil service conditions of employment are clearly of the only competence of EU Members. According to different constitutional provisions, there is a possibility of choice between a law on the civil service (necessary in France or Germany or Ireland), other statutory instruments (in the United Kingdom regulations applying to the civil service - if any - are taken in the form of "orders in council") or even internal rules of a different grade of legal binding force.

609. As far as free movement of workers is concerned, EC law makes it necessary to rely on legally binding instruments, but for the rest only internal legal principles are relevant. In most cases (except the United Kingdom) all matters relating to the political status of civil servants as citizens are settled by acts of Parliament, whereas matters relating to the management of the civil service may be settled by governmental statutory instruments in a number of countries. The main criterion for choice - apart from specific constitutional traditions - is clarity and openness of the decision making process. This is the reason why some countries prefer a general law on the civil service, whether other use governmental statutory instruments preceded by intense consultation of trade unions and professional bodies. In many countries there is a difference between general principles applicable to the whole civil service, set down in an act of parliament, and specific rules settled in statutory instruments only applicable to special groups of civil servants.

610. A tendency to codification exists in a majority of countries, but it has to be noted that codification does not necessarily mean legal binding force: the traditional "Estacode" of the British civil service mainly contained the description of rights, duties, procedures having the force of a moral code of conduct. Another rather general tendency is to settle conditions of employment by collective bargaining; depending on constitutional and legal principles the result is binding by the mere force of a collective agreement like in Italy or must be consolidated by law or delegated legislation. 
611. In the case of candidate states, special attention in the framework of an assessment should obviously be given to transitional provision, as most governments will be conducting in the same time negotiations for accession and civil service reform.

\subsection{Duties and Rights}

612. A prominent part of civil service laws is usually devoted to duties and rights of civil servants. There is not comprehensive and homogeneous list of those, common to all EU Members of the EU. Special attention has to be devoted to not only the formulation of those rights and duties - specially for the sake of clarity, which means that statutory instruments have to be preferred to internal practices and courts' case law - but specially to means of enforcement, which vary greatly from one principle to the other. A very useful way of proceeding for this purpose is not only to distinguish between rights and duties, but also especially between duties to the public and duties to the service.

\subsection{1. $\quad$ Duties to the Public}

613. In a modern civil service, duties to the public should come first, even if this is not usually the case in the formulation of civil service laws. The most prominent duties to be found in this context are the duty to be impartial, the duty to answer questions and provide information, to be combined to the duty of professional discretion as far as information concerning individuals are concerned and the duty to disobey illegal orders.

614. The latter has been given special attention not only in civil service laws but also very often in penal codes after the experience of the fascist and Nazi regimes and the Nurnberg trials. Guarantees to enforcement mainly lie in the accessibility of judicial and administrative courts by the public and civil servants themselves, with the help if necessary of public opinion.

615. The first ones, very extended in Swedish tradition, are only getting at the forefront of concern with the civil service since ten or twenty years. They still sometimes collide with legislation on official secrets (as in the United Kingdom) or more generally with traditions of secrecy common to most EU Members but the Nordic countries. Enforcement goes through efficient systems of access to official documents and generally through involvement of the press with government work. Under the pressure of Nordic countries, the EU is giving more and more attention to this aspect.

\subsubsection{Duties to the Service}

616. Duties to the service are the more classical ones in most EU Member States.

617. In most countries the first duty of a civil servant is to devote his entire working time and capacity to the service. This may be combined with a limited possibility of work outside of the service like acting as a trainer or writing, but these possibilities have to be very narrowly and clearly foreseen. Those EU Members, like some Mediterranean countries, which have accepted the possibility to have other professional activities outside of office hours - usually in order to compensate for low salaries - have found out that this was a very important cause of poor quality of public administration. It should be recommended to avoid such a possibility, even for part-time government employees. Enforcement of these principles, which can be easy and quite automatic once they are well established, demands a special effort 
and usually procedures of outside auditing and control in order to become effective, avoiding phenomena of internal complicities in the service.

618. Other duties to the service are mainly linked to the necessity of guaranteeing loyalty to the country, to public institutions and the government of the day as well as obedience to hierarchy. They are usually enforced by means of disciplinary procedures and find their limits in democratic rights and in the disciplinary procedure itself.

619. Amongst more recent duties of civil servant some countries highlight the duty to undergo professional training and to adapt to new conditions of work. This should be particularly born in mind in the light of accession to the EU.

620. As far as duties to the service are concerned, a great clarity in formulation is a precondition, but can only work in the context of an efficient human resource management, in order to avoid phenomena of organisational inertia too common to most big bureaucracies, be they public or private organisations.

\subsubsection{Rights}

621. Civil servants' rights have a prominent part in civil service laws which were the consequence of a strive to democratise the functioning of public administration. They have to be considered as incentives but also as part of democracy and the Rule of Law. Several categories of rights can be distinguished.

622. Civil servants enjoy rights as citizens. Although a general tendency is to let civil servants enjoy the same rights as all other citizens, a number of restrictions are considered as normal by some countries. No limitation to equality of treatment is accepted, which means that either the civil service law has to specifically forbid discriminations and provide for enforcement systems, or that general legislation against discrimination has to be applicable to civil service employment.

623. Generally speaking, the expression of political opinions is free but has to be moderate in form and tone. Some countries restrict the right to strike, such as Germany where it is totally forbidden for civil servants - but can be exercised by public service employees. Some countries restrict the right to participate in political activities, such as Great Britain where higher grade civil servants are forbidden to be members of political parties and where a civil servant has to resign prior to participate in an election. In other countries however, civil servants not only are totally free to participate in political life, but they also enjoy a particularly comfortable situation as they automatically return to the civil service after having hold a political position, as in France, Germany and Spain where a great number of members of parliament and of prominent politicians are civil servants on temporary leave.

624. Civil servants also enjoy rights as employees: working conditions, salaries, leave of absence, holidays etc. have to be organised as well as participation in trade unions, in co-management institutions. In many cases this can be settled by reference to labour law or collective agreements, even if it is quite often formulated specially in the civil service law. Although it is difficult to make a generally applicable statement about this point, differences of salaries between the civil service and business are rather minor and usually decreasing in EU Member States. Some hierarchical levels get better pays than their counterparts in the private sector in some countries but not in others.

625. A permanent question is whether public employees should enjoy specific rights, different from those or private sector employees, e.g. specially a right to a permanent job. Apart from specific regulations applying to trial periods or to non permanent posts, most EU governments appoint civil 
servants without any time limit other than retirement, which amounts to a certain form of tenure. It must however be stressed that all civil service laws include the possibility of a disciplinary dismissal, which is quite often practised, and that in many cases, the possibility to dismiss civil servants either because they are not adapted to their job or because of structural changes in public administration exists in legal terms. Practice however in most countries is to try and avoid such dismissals — for good and bad reasons.

626. Special attention has to be given to protection by the service against the public. In some situations, hostility against government is directly turned at civil servants who are thus scapegoats of political struggles. Here the necessity of protection is obvious. But as it is also often difficult to draw the limit between cases of maladministration notwithstanding the good work of civil servants and those where the employee himself is one of the causes of maladministration, a system has to be developed enabling redress of torts by liability of the institution without de-responsibilisation of the civil servants. Civil service laws can only lay down the right to protection and the duty to accomplish the job in the best way possible. The rest is to be settled by means of an adapted administrative law on public liability on one side, and by modern management - close to the customer - on the other.

\subsection{Recruitment}

627. All EU Members recognise equal access on merit as the governing principle for recruitment to the civil service. In some countries the stress is on merit and recruitment techniques are mainly seen as a way to get the best candidates for vacancies, in others the stress is more on equality as access to the civil service is considered as a very important citizen's right. In almost all countries — but for the Netherlands and some Nordic countries - recruitment systems have been built as a reaction to political or social patronage or nepotism and therefore are incorporating procedures to warrant equality which sometimes are perceived as cumbersome and rigid bureaucratic procedures.

628. In only one country - the Netherlands - recruitment to the civil service in the narrow sense of the above mentioned definition is based on free choice by the head of the department where vacancies have to be filled. On the other hand, recruitment is in most countries based on free choice for government employees who are not civil servants, but in Italy for instance, the constitutional principle is that all government employees notwithstanding their legal status have to be recruited by competitive examination.

629. Germany is the only country with the Netherlands not to practice competitive examination, but choice is not entirely free as candidates to the civil service must have passed very difficult state-examinations (Staatsexamen) which only differ from competitive examinations by the fact that there is no predetermined number of people to be admitted. All other countries are practising competitive examination - although in varying forms. In Spain, a very useful distinction is made between "competicion" and "concurso". In the case of "competicion", candidates are selected by an independent jury by means of examinations, a part of which is written in order to practice a first selection amongst anonymous candidates so as to guarantee impartiality of choice. In the case of "concurso" candidates are selected directly on the basis of a submitted file and interviews - thus leaving room for favouritism but also enabling a possibly better adapted choice. In most other countries the majority of competitions even if called "concours" or "concorso" etc. follows the model of "competicion" while there is also usually room for "concurso" type recruitments bearing the same label of "concours". The first category is much more difficult to manage than the second, but it is the only effective way to stop patronage.

630. In the majority of EU Members, developed systems of appeal exist against the decision of recruitment and they make for a statistically very important part of civil service case law. EC law has an impact here. As far as recruitment is for jobs or careers open to non-nationals, principles laid down by the 
ECJ compel EU Members to have systems of judicial review effectively open to candidates and to enable candidates to know the motives of a possible rejection of their candidacy. Even if EC law does not apply to the entire civil service it is hardly feasible to have better guarantees for non-nationals than for nationals as far as access to the civil service is concerned. Therefore countries where recruitment is not submitted to detailed judicial control will probably have to adapt their systems because of the impact of EC law.

631. Some countries differentiate external recruitment - open to all with only conditions of academic degrees - from internal recruitment - reserved to government employees. Here again the impact of EC law is gradually more and more important: according to the ECJ, public service employment in other EU Member States have to be considered as equivalent to employment in the state where recruitment takes place (23/2/1994 Scholtz v./Opera universitaria di Cagliari, case 419/92). If governments want to keep this instrument of promotion in the civil service, they have to be very careful in defining the conditions of access to internal recruitment in order to avoid making their system ineffective by opening it too much and on the other hand avoid restricting it in a way which would collide with EC law.

632. The system of employment in the civil service - career system or employment system obviously has consequences on the nature and content of recruitment procedures. In the framework of a career system the recruitment to the service - at the beginning of the career - is very different from the selection for a given position whereas they do not differ in the framework of employment systems.

\subsection{Mobility}

633. Mobility is a very important issue in all civil services, whatever system - career or employment - is chosen. The main difference between the two systems can be defined as such: in a career system, mobility is considered as the problem of the organisation and thus detailed provisions for mobility are laid down in civil service laws and regulations, whereas in an employment system mobility is considered as the employee's problem and occurs according to opportunities. Traditionally in the EU Members apart from the Netherlands, EU government generally have chosen a career system for their civil servants, reserving employment systems to non civil service government employees. It is probably useful to note that even the Netherlands government is now exploring the way of organised mobility - i.e. a career system - for the top managers of the civil service.

634. Mobility is usually considered as an incentive for members of the civil service, a way of renewing human resources thus increasing the dynamism of civil service, and one of the components of a culture fostering internal co-ordination in government. A very important issue in this context is the size of the unit of civil service management: if the civil service is very fragmented - as a result of traditional boundaries between departments or of the creation of autonomous agencies - mobility is much more difficult to organise than in a system of government wide civil service.

\subsubsection{Vertical Mobility}

635. Vertical mobility is usually considered as one of the major incentives for civil servants together with and sometimes above good salaries, pension prospects and interesting work. It is the main concern of career systems but cannot be neglected in employment systems. In the framework of career systems a balance has to be found between formal criteria and performance. Amongst formal criteria length of service is the most easy to define and to use but others, like examinations or training periods can be used in order to avoid seniority becoming a negative incentive. 
636. In many countries criteria for vertical mobility are formulated in a general civil service law or regulation. This usually goes together with the definition of different groups or categories of civil servants, according to the level of recruitment - secondary school, A level (baccalauréat - Abitur), academic degree. One of the big problems then is mobility from one category to the other, which can be solved by means of internal recruitment.

637. In France and Spain, careers are managed in the framework of so called corps or cuerpos of civil servants - more than a thousand different corps exist in each country for national civil service. Criteria for mobility - vertical as well as lateral - are formulated in separate regulations specific to each corps together with particular duties or working conditions. This can become a source of fragmentation and rigidity of the public service, but on the other hand it allows in France for a clear dissociation between rank (grade) in the corps - greatly conditioning career prospects and a major part of salary - and position (emploi) in government employment - conditioning responsibilities, work and a minor part of salary. It is possible to benefit from vertical mobility in the corps in the absence of existing vacancies of positions.

638. EC law again has an impact: the ECJ considers that once recruited a foreign government employee may not suffer discriminations compared with national employees (12/2/1974, Sotgiu, case 152/73) but for positions covered by the exception of Article 48(4). In career systems, this means that regulations on vertical mobility have to take account of restricted jobs and that a precise job description has to be undertaken, covering not only jobs reserved to career beginning. In employment systems it means that appeal mechanisms have to be organised in order to make sure that mobility results only from merit and not from practical discriminations in information about job vacancies or in choices made by officials responsible for human resource management.

\subsubsection{Lateral Mobility}

639. Lateral mobility defined as mobility between government departments and agencies often is also considered as an important incentive but also as a tool of public management. It enables reshuffling of administrative structures without having to fire employees and is a major component of intragovernmental or even intergovernmental co-ordination because if facilitates mutual information and knowledge of each other's problems, interests and working methods. As such it is becoming more and more important in the context of European policy-making.

640. The record of most EU civil services in matters of lateral mobility is rather poor and there is a rather disquieting tendency for lateral mobility to decrease due to the creation of executive agencies. Lateral mobility is largely a matter of management of the civil service (see 3.7) but also depends on regulations applicable to the civil service.

641. A major tool for lateral mobility is the organisation of leaves (congés) and secondments (détachement). They are becoming a major component of co-operation between national governments and the European Commission. Career systems integrate these more easily than employment systems. A precise definition of conditions for leave and secondments - initiative of the employee, reasons for leave and organisations to be seconded too, maximum number of employees on leave or secondment at the same time etc. - has to be given, taking in account the fact that heads of services are usually reluctant to see their good employees quit the service even temporarily. It must be also very clear how the link with the civil service is maintained in matters of pension rights and future promotion and - most difficult in practice - how civil servants will be reintegrated in the service at the end of the period of leave or 
secondments. Secondment to and from European institutions and other EU Members' administrations has also to be taken care of.

642. An emerging problem of lateral mobility is that of persons wanting to follow a career path including periods in different EU Members and European institutions. Secondment provisions are only one possible solution. An effort is presently undertaken by the Commission and EU Members departments responsible for the management of civil services in order to allow for transfer of pension rights and possibly of seniority rights from one civil service to the other.

\subsection{Training}

643. Training of civil servants is becoming more and more important in all EU Members as well as in European institutions, especially in the form of in-service training, sometimes linked to career development. Several different models for training exist throughout the EU.

644. France and Spain are the only countries with a long established tradition of civil service schools, closely linked to the corps system. In France several hundreds of these are to be found. They are in charge of recruiting candidates with education or academic degrees but also through internal recruitment and of preparing them for their future jobs. In other countries, schools and institutes of public administration focus more on in-service training. The impact of EU membership mainly concerns the necessity of European training, but gradually a problem of mutual recognition of training for and experience in the civil service is emerging, especially in the fields of health and education. Here again an effort is undertaken by the Commission and EU Members departments responsible for the management of civil services in order to allow for intra EU careers.

\subsection{Management of the Civil Service}

645. The diversity of organisation and techniques in the management of the civil service is quite large amongst EU Member States and allows for a wide range of experiences to compare.

646. At government level the main issue is centralisation or decentralisation of civil service management. In a number of countries like France, Portugal or Spain and formerly in Ireland as well as at times Great Britain, a special ministry of public administration or of the civil service is in charge of the general aspects of civil service management like preparing the laws and regulations on civil service, organising or monitoring recruitment, co-ordinating human resource management and negotiating with trade unions. In other countries like Belgium, Germany or the Netherlands this is the role of the Ministry of Interior or of the Finance Ministry (Ireland nowadays). In Italy a special executive agency has been set up in order to negotiate with trade unions in the name of national and local governments and agencies. Having a specialised department in charge of the civil service does not necessarily mean a centralisation of human resource management, which can be nevertheless deconcentrated at department or agency level. Two conflicting series of issues have to be balanced: the need for autonomy and efficiency of line managers which pushes towards a maximum of decentralisation on one side and the issues linked to equal treatment and mobility on the other which require a certain degree of centralisation.

647. At department or agency level it is not possible to present a comprehensive picture of practices throughout the EU. A rather general feature is that of civil servants' representation in decision making process relating to civil service issues. This is usually seen both as a necessity of democracy and a possible source of rigidity in human resource management. "Social dialogue" in the public sector is an 
important focus of attention, since almost a decade for the Commission and some national governments in the framework of meetings of the ministers in charge of the civil service.

648. As far as payment systems are concerned most EU Members use a general common scheme for salaries in government. This means that a major aspect of job classification is to relate each position in government employment to a point or a series of points in a general salaries' grid. This however does not preclude a number of possibilities of variations through bonuses or other means, which usually have been designed in order to allow for performance related pay, but which tend to become unified in practice at department or agency level.

649. Whereas participation in the EU has no direct consequences on these issues, comparison of experiences of EU Members in matters of management of the civil service leads to the conclusion that established systems should be revisited from time to time, as there is a constant tendency in bureaucracies - public or private - to develop antidotes to regulations, structures and procedures which have been established with the best possible intentions. 


\section{FURTHER READING}

AUER, A., DEMKE, C. and POLET, R., eds. Civil Service in the Europe of Fifteen - Current Situation and Prospects, European Institute of Public Administration, Maastricht, Netherlands, 1996. (Also available in French and German).

BODIGUEL, J-L. Les fonctions publiques dans l'Europe des Douze, LGDJ, Paris, France, 1994.

CLAISSE, A. and MEININGER, M-C.. Fonctions publiques en Europe, Montchrestien, Paris, France, 1994.

"L'acces des ressortissants CE et des étrangers ordinaires aux fonctions publiques". Administration publique - Revue du droit public et des sciences administratives, Institut français des sciences administratives, Brussels, Belgium, T 1/1997.

MAGIERA, S. and SIEDENTOPF, H. Das Recht des öffentlichen Dienstes in den Mitgliedstaaten der Europäischen Gemeinschaft, Duncker \& Humblot, Berlin, Germany, 1994.

ZILLER, J. Administrations comparées - Les systèmes politico-administratifs de l'Europe des Douze, Montchrestien, Paris, France, 1993.

ZILLER, J. Égalité et mérite - l'accès à la fonction publique dans les Etats de la Communauté européenne, Bruylant/European Institute of Public Administration, Brussels, Belgium, 1988.

ZILLER, J. Top Management Service in Central Government -Iintroducing a System for the Higher Civil Service in Central and Eastern European Countries, SIGMA Papers: No. 1, SIGMA/OECD, Paris, France, 1995. 
Chapter 10: The Impact of EU Accession on Budgeting, Control and Audit

By Kjell Larsson and Richard Allen ${ }^{40}$

40. Kjell Larsson of Sweden is Senior Counsellor for Administration Oversight, Financial Control and Audit at SIGMA. Richard Allen of the United Kingdom is Senior Counsellor for Budgeting and Resource Allocation, SIGMA. 


\title{
1. Introduction
}

650. It is clear from the Opinion published by the Commission in July 1997 that, in general, the budgetary and control systems of the applicant countries in Central and Eastern Europe fall short of standards set by the Commission and by existing Member States. The Opinion includes many references to the need for candidate countries to develop their institutional and administrative framework in order to ensure effective administration of the acquis communautaire in the budgetary area; and to consolidate and improve the overall professional standards of staff, including training and improvements in pay. These Commission recommendations cover not only the ministry of finance but all ministries and agencies (e.g. tax and customs authorities, ministries of regional development) involved in the handling of Community funds. The Commission has, for example, argued in the Opinion that:

\begin{abstract}
"the protection of the Community's financial interests requires the development of anti-fraud services, training of specialised staff (investigators, magistrates) and the reinforcement of systems of specific co-operation. The implementation of Community policies, especially for agriculture and the structural funds, requires efficient management and control systems for public expenditure, with provisions to fight fraud. Administratively it is essential to have a clear separation between external and internal audit. Police and judicial authorities need to be able effectively to handle complex transnational financial crime (including fraud, corruption and money laundering) which could affect the Community's financial interests."
\end{abstract}

651. SIGMA has recently published a study - in two volumes - that describes the experience of national ministries of finance and supreme audit institutions of seven EU Member States (including the three countries - Austria, Finland and Sweden - that joined most recently) in integrating national and EC budgetary procedures and requirements ${ }^{41}$. SIGMA believes that a pooling of the responses of different Member States to the budgetary, financial control and audit requirements of membership could be instructive for the applicant countries of Eastern and Central Europe, as well as signposting issues for possible future examination in the context of the EU's ongoing programme of financial management reform.

652. Section 1 of this paper attempts to put the issues reviewed in the SIGMA study in a broader context. How will eventual EU membership affect the national budgets and budget systems of the applicant countries? What are the wider implications for reforming the budgetary institutions in these countries? Section 2 of the paper highlights some of the main lessons learned from the SIGMA study. This is a distillation of some of the experiences recorded by the Member States. It is necessarily both simplified and selective. Section 3 of the paper presents some conclusions.

\section{The Fiscal Impact of EU Enlargement}

653. The Commission's recent Communication "Agenda 2000" - covering the period from 1999 to 2006 - sets out an overall framework which is intended to accommodate the budget impact of any future EU enlargement over the medium-term. In the case of the five countries (Czech Republic, Estonia,

41. Effects of European Accession, Part 1: Budgeting and Financial Control, and Part 2: External Audit, SIGMA Papers Nos. 19 and 20, SIGMA/OECD, Paris, 1997. Also available in French. 
Hungary, Poland, Slovenia) which the Commission has recommended are ready to commence accession negotiations with the Council, the budget allocations proposed by the Commission for expenditure on agriculture, structural adjustment and other policies are less generous than those applying to existing Member States. Nevertheless, the net impact of membership on the national budgets of the five countries should be substantially positive. This is because their GNP per capita and fiscal potential is substantially below the average of the existing Member States, so that their receipts from Community expenditure programmes should greatly exceed their total contributions to the EU budget.

654. The magnitude of the net fiscal benefit to the new Members will vary from country to country depending on:

- the date on which the country joins the Community;

- developments in EU policies between now and then, in particular, decisions on future reform of the Common Agricultural Policy and new guidelines for the Structural Funds;

- progress made by candidate countries in terms of economic growth, competitiveness and productivity and their ability to apply the acquis;

- any transitional measures that result from the negotiations.

655. The net budgetary benefit of EU membership is likely to decrease with any further waves of enlargement since the average fiscal potential of a Community of 20 Member States will be smaller than for the existing EU15.

656. On the expenditure side, most applicant countries should benefit substantially from the Structural Funds - on the figures in "Agenda 2000" by up to 4 per cent of GNP of their GNP, after the phasing in period - and, to a generally lesser extent, from the Common Agricultural Policy and other Community expenditure programmes.

657. On the revenue side, new Members' contribution to the Community budget should, in terms of total GNP and VAT resources, be close to the proportion of the EU's GNP they account for. This ranges from less than 0.1 per cent in the case of Estonia to about 1.8 per cent in the case of Poland. These countries' share of the "traditional own resources" (ie. import duties and agricultural levies) will depend on the structure of their trade flows at the time of accession and in the future.

\subsection{EU Membership and Budgetary Autonomy}

658. Membership of the Community will diminish the budgetary autonomy of the new Members for several reasons:

- in order to manage EU budgetary funds (both revenues and expenditures) in compliance with EU regulations, each new Member State will have to develop new systems for collecting, monitoring and evaluating financial information; and radically change their financial control and audit procedures, as described later in this paper;

- Community regulations substantially limit the capacity of Member States to determine the structure and rates of VAT and customs duties. Over time, fiscal competition, operating through the single market and international trade, is likely to increase pressures for bringing the rates and structures of other taxes towards the "average" or "general" level in the Community as a whole; 
- the development of a European common currency and the implementation, under the Maastricht Accord, of the so-called macro-economic "stability pact", will greatly sharpen the need for fiscal discipline in the Member States and thus further reduce their budgetary independence;

- for similar macro-economic reasons, Member States will have to exercise greater control over the financial behaviour of local authorities' budgets and funds such as social security which, in many countries, are not counted as part of the state budget but affect the overall level of public expenditure and borrowing. This may create tensions with policies of decentralisation and "fiscal federalism" that are being encouraged in Europe (e.g. by the Council of Europe).

659. Thus, broadly speaking, new Member States are likely to experience:

- a positive economic impact since enlargement will increase their net budgetary capacity;

- a negative impact on the new Members' national budgetary sovereignty;

- a greater concentration of fiscal power at the centre of government and, especially, with the Ministry of Finance.

\section{The SIGMA Study: Experience and Lessons Learned}

660. As emphasised in the SIGMA study, compliance with the European Commission's budgetary and financial control requirements is one of the basic objectives of EU membership. The subsidiarity principle applies in this area, however, and, until recently, budgetary requirements were not described in any specific mechanisms. Member States are thus free to decide how to integrate EU budgetary flows receipts and expenditures — with their own national budgets.

661. The mechanisms for managing EC finances have been the focus for continuing debate among the institutions and within the Member States for the past decade. Important reforms have been introduced with the aim of increasing accountability and value for money. Enlargement and the preceding negotiations are likely to add impetus to the process of reforming both the EC's budgetary rules and some of the principal expenditure policies borne by the budget, notably the Common Agricultural Policy and the Structural Funds. The SIGMA study shows that, particularly for the most recent Member States, accession may be one element in a process of fundamental reform of national political structures and financial systems. In such cases, the reform processes at EU and national level can be mutually supportive.

\subsection{The EC Budget}

662. The Commission, Council and Parliament all contribute to the process by which the EC's budget is adopted annually, with the Parliament having the last word in most areas. The process is a long and complicated one - starting in February and usually finishing in December. Not only is each Member State expected to give its opinion on the general outlines (macro-economic framework, fiscal projections, etc.) but also on the detailed expenditure proposals in the draft Finance Bill. Familiarisation with the budget process and procedures is an essential priority for any new Member State.

663. Member States contribute all the EC budget's revenue and execute more than 80 per cent of the spending, though the Commission retains ultimate responsibility for implementing the budget. From a Member State's point of view, some EC budget expenditure replaces equivalent national expenditure. This used to be true for most of the EU's agricultural support spending, and is still true of part of it. There are 
other expenditures which are demonstrably and intentionally additional to the equivalent national programmes. The Structural Funds are the clearest case in point.

664. As the SIGMA study shows, a Member State needs to equip itself to perform three main types of role in relation to the EC Budget:

1. An information role: the Member State needs reliable information, in an accessible form, in order to monitor and forecast the impact of the EC budget on the national budget; it is also an essential source for the Commission of budgetary data, notably forecasts of own resources, movements of agricultural stocks and the rate of progress of Structural Funds programmes. The Member States have a general duty under Article 5 of the Treaty (to be reinforced by the Treaty of Amsterdam) to assist the Commission in its responsibility for managing the budget.

2. A negotiating role: in its own interest the Member State will wish to negotiate (a) as a member of the Council, about the size and composition of the budget; and (b) as a member of the Council and bilaterally with the Commission in order to maximise its benefit from Structural Funds.

3. A compliance role: the Member State must comply with all relevant EC rules about collection and transfer of EC budgetary revenue and the proper management of funds received from the EC Budget. It must be vigilant in preventing, detecting and reporting fraud and irregularities against EC funds. The Commission requires a Member State not only to comply with the rules, but to be able to demonstrate after the event, on the basis of documentary records or other evidence, that it has done so.

665. For new Member States, as for the seven countries reviewed in the SIGMA study, effective fulfilment of these roles is likely to involve some changes in machinery of government and the expenditure of some additional resources. Accounting and audit expertise, and computing resources, will be of special relevance. There is hardly any season of the year when budgetary business of one sort or another is not on the Council agenda at ministerial or official level in Brussels. The range of interests affected by the EU Budget, and the speed of response required from national representations in Brussels, make it imperative for a Member State to have effective procedures in place for co-ordinating the views of different government services.

666. The national budget is the principal instrument used by existing Member States in order to account for the flows of funds to and from the EC budget. Receipts from the EU are entered on the revenue side of the national budget (or occasionally shown as negative expenditure) while the expenditure side shows the disbursement of the same funds to beneficiaries and part (or sometimes all) of the national contribution to the EC budget. This treatment is not a requirement of EC law, and there are significant differences between the practice of different Member States. For example, the United Kingdom enters all transactions with the EC budget on the expenditure side of the national budget. The Finnish authorities account for the price support subsidies of the Agriculture (Guarantee) Fund in a separate intervention fund which is outside the budget and endowed with its own borrowing power. (There are, however, rules on the way in which flows of funds involving the EC budget must be treated for national accounts statistics purposes.)

667. Since most Member States use gross accounting in their budgets, this treatment adds to budget totals of both revenue and expenditure. The figures concerned are not likely to be a valid substitute for a comprehensive analysis of the EC's budgetary impact since, in most cases, they omit an important part of the national contribution and some receipts. 
668. On the other hand, the practice has the advantage of convenience, and this is the main reason why Member States have adopted it. Most of the flows of funds could be accommodated without difficulty in existing budget headings. More importantly, from both a national and EU point of view, this practice ensures that the same safeguards and controls are ipso facto applicable to EC as to national budgetary funds. This approach seems to have practical as well as cost advantages. It should also facilitate compliance with the Maastricht Treaty which requires Member States to be equally conscientious in the protection of EU and national financial interests. This is a good example of the kind of question which applicant Member States could discuss informally in advance of accession with the Commission and selected Member States.

\section{2. $\quad$ The Role of the Ministry of Finance}

669. If a Member State is to manage effectively the EC budget process, and integrate this into its national budget procedures, the experience of the countries reviewed in the SIGMA study indicates that the ministry of finance must play a central role. In western countries, ministries of finance are both an important part of the small group of policy-making ministries and offices at the "centre of government" and, in many cases, provide direct advice to the prime minister on economic and financial issues. They play a crucial role in the planning and execution of the national budget (and its links with the Community budget) and in the policy making process itself. For example, line ministries and other spending agencies will usually be required to obtain the ministry of finance's opinion before any policy proposal that has financial and public expenditure implications is submitted to the council of ministers. In addition, the ministry of finance will typically provide technical support to spending agencies in analysing the economic and financial implications of policy options, and to challenge these agencies if the information or analysis they provide is inadequate; to establish a common framework - through the issuing of regulations and guidance to line ministries - on financial management and control techniques and systems; and to verify that these systems have been implemented and operate effectively.

670. Such functions - which require the necessary constitutional and legal powers, a high level of technical skills and very good access to financial information - may be beyond the capacity of ministries of finance in many central and eastern European countries whose responsibilities, in the budget and control area, often do not extend much beyond the legal requirement to act as "paymaster" to government spending agencies. Thus, in these countries, there is commonly no requirement for the ministry of finance to take responsibility in ensuring that public expenditure achieves value for money (economy, efficiency, effectiveness) or that the financial management procedures and systems (staff, IT, training, etc.) of spending agencies are organised within a common framework and meet certain standards of regularity and efficiency. One major challenge for countries in Central and Eastern Europe is to provide their ministries of finance with the legal authority to fulfil such functions, and with the necessary technical skills and other resources. In order to achieve the degree of fiscal discipline that is necessary to comply with the Maastricht Accord, countries may also need to strengthen their budget processes ${ }^{42}$.

42. A recent study concludes that "a budgeting process that gives the prime minister or finance (or treasury) minister a position of strategic dominance over the spending ministers, and that leaves little room for changes in the budget during the execution process is strongly conducive to fiscal discipline, ie. relatively small deficits and public debt. A strong position of the prime minister or the finance (or treasury) minister and limited parliamentary power enable the government to commit fiscal strategies limiting expenditures and deficits and to defend these strategies against the political pressures for more profligate policies which spending ministers and members of parliament are exposed to in the day-to-day political process. Appropriate 
671. Changing the powers of the Ministry of Finance relative to other ministries is, of course, a sensitive matter for most countries, and will need careful preparation and management.

\subsection{Customs and Tax Administration}

672. The strong impression given in the SIGMA study is that adaptation to the requirements of the own resources system was a laborious experience for most of the Member States.

673. A prospective Member State will need to adapt its frontier and domestic taxation arrangements in order to deliver to the EU sufficient sums of "own resources" (customs duties and agricultural levies) and the required share of VAT revenue. In the Portuguese case, for example, one of the major problems of accession was the necessity to improve officials' skills at all levels in the customs administration. The solution adopted was a comprehensive training course in the Commission for customs officials. Accession to the EU will involve the adoption of EC levels of levies and customs duties (subject to any transitional arrangements), including any changes that may be required in national legislation. It will also involve the introduction of a VAT system of indirect taxation where such a system does not already exist.

674. The provision of EU-compatible GNP data can also cause difficulty for new Member States. The Swedish authorities have commented: "With regard to the various types of payment that constitute our own resources in the EC budget, VAT-based payment is the most complicated and requires new calculations and good statistical documentation....It is also essential to adjust the system of national accounts in such a way that it can supply the information required to calculate the GNP-based payment". This will require upgrading the capacity and skills of National Statistics Offices. An early start should be made in planning and implementing the necessary changes.

675. While the overall evolution of a Member State's budget contribution is a matter for the national ministry of finance, the management of its component parts is likely to involve different agencies and levels of government. Agricultural policy, customs, indirect taxation and statistics are among the main areas concerned. Most Member States have found it necessary to set up a specialist unit within the budget sector of the ministry of finance to co-ordinate all action in connection with the calculation, reporting and payment of their contribution. In this way, the distribution of powers amongst ministries has been altered. Today the ministry of finance has a much stronger position.

676. There are some further important implications of EU integration for customs and tax administration in new Member States.

677. First, the trend in tax collections in the customs area is strongly downwards. Internal duties will disappear with the completion of the single market, whereas external duties are being eroded under successive "GATT round" pressures. An important implication of EU membership is that Customs services will have to adapt their administrative systems to these changing circumstances and pressures. For example, the application of Schengen principles, where applicable, will lead to a withdrawal of all customs officers from border posts. Similarly, border controls for VAT collection purposes have been

institutional reforms can help governments and parliaments to materialise a newly reached consensus for greater fiscal discipline." See J. von Hagen, "Budgeting Procedures and Fiscal Performance in the European Communities", European Commission Economic Papers, No. 96, October 1992. 
removed, though the "destination" principle of VAT collection has been retained for the time being ${ }^{43}$. Some customs administrations are responding to these developments by downsizing their traditional operations and redeploying resources into areas such as controls of drugs and money laundering. This implies an ever increasing need for co-operation between the customs services, police and judicial authorities in the Member States.

678. Second, the expected impact (indeed the objective) of the single market is to create a much more open, competitive and flexible market, not only for goods and services but also labour and capital. As noted above, this could lead to growing tax competition and further restrictions on Member States' freedom to make changes in the structure and rates of taxes for macro-economic or micro-economic policy purposes. Moreover, viewed from a Community perspective, the tax base will become progressively more mobile, fluid and volatile and thus more difficult to monitor and "capture" by national tax authorities. As a consequence, there will be pressures for stronger intra-European co-ordination between the tax authorities, for example, through exchanges of information, files and staff.

\subsection{Managing the Agriculture and Structural Funds Programmes}

679. The Agriculture (Guarantee) Fund accounts for about half the total expenditure of the EC Budget. Day-to-day management of the expenditure is devolved to Member States, which are fully reimbursed by the Commission. There is a delay of at least $2 \frac{1}{2}$ months between disbursement of funds to beneficiaries and reimbursement by the Commission. A new Member State must therefore be prepared to provide the initial start-up finance.

680. Each of the various measures financed by the Fund is defined in permanent, specific legislation (Council and/or Commission regulation). The annual budget authorises sufficient funds to enable the Member States to fulfil their obligations to beneficiaries in accordance with the different measures. Expenditure on some of the measures, notably those directed at price support, is volatile and difficult to forecast. Numerous working groups in Brussels try to keep track of the expenditure from month to month, while other working groups examine Commission proposals for new or amending legislation - typically with a view to strengthening financial and accounting controls in Member States, and reducing the risk of fraud. This activity makes significant demands on the time (and negotiating skills) of a Member State's agricultural and budgetary experts.

681. The Member State is obliged to set up one or more paying agencies as the vehicle for disbursement to beneficiaries of receipts from the Fund. Paying agency status is granted (by the Member State) only to bodies which can demonstrate an ability to maintain high standards of accounting, financial management and financial control. The criteria which a Member State has to apply in deciding whether to grant paying agency status were spelt out in detail in a 1995 Regulation (Regulation 1663/95). The Member State must also select a certifying body (which must be operationally independent of the paying agency and need not be in the public sector) to audit the annual accounts of each paying agency.

682. Under the so-called "clearance of accounts" procedures, the Commission reviews the paying agency's annual accounts in the light of the certifying body's audit. In addition, and separately from the annual accounts, the Commission may subject the paying agency's handling of EC funds to a more searching audit of compliance with EC rules. This sort of audit often covers more than one Member State.

43. Should the VAT "origin" principle be introduced, this would have further implications for the organisation of tax collection in the Member States. 
If the Commission finds evidence that the paying agency has failed to comply with EC rules, it reduces the agency's current year funding by an amount which reflects the Commission's assessment of the loss to EC funds.

683. The paying agency is also subject to audit by the European Court of Auditors, the EU's external audit body. The Court has no direct power to sanction Member States, but its findings, which are presented to the Council and the Parliament, may lead the Commission to recover any irregular payments and, in certain cases, to terminate further payments to the country concerned. Member States are increasingly expected to reply to any criticism of their management of EC funds by the ECA and to explain what they have done to put things right.

684. Regulation 1663/95 represents an important new departure from the EU's previous practice of allowing Member States to interpret EC financial control requirements in the light of their national administrative traditions and practice. It also demonstrates that there need be no incompatibility between the doctrine of subsidiary and the Commission's responsibility for safeguarding Community assets.

685. A paying agency needs staff who are conversant with both the agricultural and the budgetary legislation of the EC and a place within the structure of government which enables and encourages them to co-ordinate their work with their colleagues in the Ministry of Finance. Above all, the paying agency needs staff who are competent in financial management and a structure which gives due weight to the requirements of financial control.

686. The Structural Funds co-finance multiannual programmes in the Member States. In contrast with the expenditure of the Agricultural (Guarantee) Fund, which is characterised by a high degree of automaticity, there is a substantial discretionary element in the spending of the Structural Funds. Optimum exploitation of the potential benefits of the Structural Funds is a labour-intensive exercise for Member States, both for this reason and because of the extensive co-ordination which is required in pursuit of the principle of partnership, which is basic to all the Structural Funds' operations.

687. For the national authorities, the preparation of bids for aid involves co-ordinating the views of different levels and agencies of government, and of non-governmental bodies. The monitoring of existing programmes is another collective operation, in which representatives of national, regional and local government and of the Commission all participate. For historical reasons, there is some overlap between the objectives supported by the different funds. For all these reasons, co-operation with the Structural Funds has led to increases in the workload and changes in the procedures of some governmental agencies in most Member States, and in some cases the creation of new structures, such as the special units set up by the United Kingdom and the Portuguese authorities, in the latter case prior to accession.

\subsection{Financial Control}

688. As regards financial control, Member States are required to verify the efficiency and regularity of all operations aided by the Structural Funds, and to tell the Commission how they propose to fulfil that obligation. They also have a specific obligation to certify the validity of claims for payment, and in the case of final payments arrange for an independent certificate. These obligations are less comprehensive and less detailed than the criteria which Regulation 1663/95 established for the authorisation of paying agencies. Nevertheless, in at least one case (Sweden) they were a contributory factor in a Government decision to set up new internal audit units in the principal government agencies responsible for handling receipts from the Structural Funds. 
689. The Commission services can and do conduct on the spot audits of Structural Funds expenditure in the Member States, and may also require the Member State to carry out specific enquiries. The operations of the Structural Funds are also subject to audit by the European Court of Auditors. Any evidence of irregularity is likely to lead the Commission to insist on reimbursement by the recipient and is increasingly likely to lead to a net financial cost to the Member State. In some instances - and increasingly so - the system of reimbursement is highly automized.

690. The activities of the various financial control and audit services at EU and national level have not always been co-ordinated to best effect. It is clear that countries have to find new and more efficient methods of co-ordination. This is partly a matter of the institutions concerned committing sufficient resources and time to the task, partly a matter of agreeing between themselves a common approach and methodology.

691. Co-ordination has not been helped by a lack of clarity in the division of responsibilities between the multiplicity of financial control and audit services in the ECA, Commission and Member States. However, it seems that co-ordination has improved in recent years, and at the same time there has been increased involvement of national financial control and audit services in the safeguarding of EC assets.

692. The position remains more fluid in relation to the Structural Funds. With a view to making the best use of all the EU's financial control and audit services, the Commission's Financial Controller has invited Member States to sign protocols which would co-ordinate both the timetable and the methodology of work by the Commission's and Member States' financial control/audit services. This proposal has caused some difficulty for Member States with federal constitutions and/or decentralised systems of financial control, but about half the present Member States have already signed protocols and negotiations are well advanced with the others. Early negotiation about a protocol could provide an applicant country with useful insights into the scope and frequency of financial control work which it would be expected to carry out after accession, the minimum standards which the Commission would expect that work to meet, and thus the extent to which existing financial control and audit services might need to be strengthened prior to accession.

\subsection{External Audit}

693. The Treaty amendments which set up the European Court of Auditors (ECA) introduced the first ever reference in Community legislation to national Supreme Audit Institutions (SAIs). The ECA's audit work in Member States is required to be carried out in liaison with SAIs; SAIs are required to inform the ECA whether they intend to take part in the audit; and are also required to forward to the ECA, at its request, any document or information necessary to carry out its task.

694. Over the past decade, the Commission, as the EU Institution responsible for implementing the Community budget, has taken an increasingly active interest in the effectiveness of the control measures applied by Member States to Community funds. It has taken important initiatives designed to involve national control services in the audit and control of agricultural subsidies and the structural funds, and to ensure that the standard of their work meets certain minimum criteria. The responses of SAIs to these initiatives have varied. While the Community has legislated about SAI/ECA relations, it has never attempted to regulate the SAI/Commission relationship by law.

695. It seems likely that the Commission will continue its policy of prescribing control and audit procedures for Member States to follow and of requiring them to observe certain minimum standards in so 
doing. Enlargement, with the additional demands that it will place on the Commission's own control and inspection services, will add a new impetus to the process.

696. Most SAIs consider that accession has led to a noticeable but not a significant increase in the volume of their audit work. The United Kingdom's SAI estimates that EU-related work takes up approximately 2 per cent of its time which "is broadly in line with the proportion of United Kingdom expenditure provided from the European Community Budget". This sort of calculation does not do justice to the unquantifiable changes in approach and organisation which accession has brought in its wake for some SAIs. The audit of compliance with EC rules requires a substantial initial effort of familiarisation with them. And implementation of the new rules can generate additional audit risk.

697. The extent of the cultural shift which can be needed is brought out in the following observation of the Swedish SAI: "We cannot exclude the possibility that, to some extent, the reason for mismanagement, irregularities, fraud and corruption in the EC payments system lies in the way the system is designed. If national and "European" budget funds are used for the same purpose, there may be a greater risk of error in relation to a relatively complex regulatory structure....The fundamental approach and structure implicit in the administration systems of control which now apply to Sweden as a result of EU membership differ in certain important respects from our national practice. This means that it is not always easy for Swedish officials to understand and implement these control systems". The auditor, in planning his priorities, has to take into account the risk that national systems of administration may not devote the same care and attention to the management of EC funds as they would to national funds.

698. There is now a well-established liaison routine which covers the scheduling, implementation and follow-up of ECA audits in Member States. The a priori conditions are that, basically, each body must itself determine whether co-operation will give it some added value. Within the Community, there are some differences in national approaches to co-operation with the ECA. The option in the Treaty for SAIs to take part in ECA audits is interpreted in a variety of ways.

699. Participation has normally taken the form of attaching a representative of the SAI to the ECA audit team as an observer. The Austrian SAI believes in a more active form of participation which raises the question whether its independence would be compromised by active participation in an audit initiated and executed by the ECA.

700. The SAIs and the ECA have been co-operating since the early 1990s to carry out a limited number of joint audits. These are audits in which the ECA and one or more SAIs pool their resources in a single audit enquiry. As a variant on that idea, there have also been some experiments with parallel or co-ordinated audits, in which two or more audit bodies carry out separate enquiries into the same subject area.

701. Several SAIs emphasise the educative value (for both parties) of joint audits. SAIs also draw attention to the relatively heavy demands which all forms of co-operation with the ECA place on their available human resources.

702. Another form of co-operation between SAIs and the ECA relates to the ECA's obligation under the Treaty to provide the European Parliament and the Council with a Statement of Assurance (SOA) as to the reliability of the accounts and the legality and regularity of the underlying actions. This is a very specific responsibility which places a big onus on the auditor to ensure, and if necessary to be able to demonstrate, that his conclusion is supported by the audit evidence. 
703. The ECA has been seeking to negotiate bilateral arrangements with SAIs on a voluntary basis in order to enable it to use the results of SAIs' audit work as an input to the SOA which the ECA has to give, at the end of each year, on the overall EC budget. The object of the negotiations is to reduce the ECA's workload in connection with the SOA and/or to strengthen the basis on which the SOA rests. A key question is the extent to which the ECA is satisfied that the SAIs' audit results are reliable. There is an affinity here with the recent initiatives of the Commission referred to above. In both cases, the national control bodies operate according to standards laid down by or agreed with Community Institutions. The negotiations have not yet been concluded, but if they are successful it might suggest that this sort of arrangement, in which the roles of the two parties are complementary rather than additive, represents a more cost-effective model of co-operation for the future than joint audits.

704. There is no provision of EU law which bears directly on contacts between SAIs and the Commission, and until recently such contacts were infrequent. Today, however, the need to establish and maintain such contacts is much more obvious.

705. The country papers included in the SIGMA study reveal divergent responses to the two Commission initiatives referred to above. In France, Sweden and the United Kingdom, the national authorities have appointed their SAIs as certifying bodies under Regulation 1663/95. In recognition of the unusual nature of their role in this matter, the French SAI has set up an auditing commission to handle the certification work, and the United Kingdom's SAI has entered into a contractual relationship with its national paying agency. However, comparable proposals by the national authorities in Denmark and Finland have been resisted on grounds of principle by the SAIs in these countries. These SAIs have emphasised that they do not think it appropriate for SAIs to be involved either directly or indirectly in the negotiations between the Commission's financial controller and national control authorities about structural fund protocols.

\section{Conclusions}

706. The SIGMA study emphasises the importance of countries making an early start to making preparations for EU membership. Several years of preparatory work are needed and many practical questions require deep and careful consideration. Countries that have based such preparatory work on early policy decisions, laying down the principles that will guide the implementation process, find this to have been of great value.

707. Training of staff is an essential element in preparation. The country papers underline the importance of language training. Training in financial management skills, and in the standards and methods of internal control and audit, is equally important.

708. For new Member States, effective integration into the Community is likely to involve changes in the machinery of government and the expenditure of some additional resources. The financial control and audit systems in government administration have to be changed, often in a fairly fundamental way. In addition, preparation for membership demands a thorough analysis, adaptation and development of existing budgeting, financial control and audit systems. This can be resource demanding - new financial information systems, for example, may be required. Experience of the most recent Member States suggests that EU accession may be part of, and help reinforce, the process of fundamental reform of national political structures, and of administrative and financial systems.

709. The requirements to conform with detailed EU budgetary and control regulations and procedures - and, more broadly, with the needs of fiscal discipline implied by the Maastricht Accord - 
put strong pressure on new Member States to strengthen their administrative systems and processes in a range of institutions including National Statistics Offices, tax and customs authorities and Ministries of Finance. Internal control systems and internal audit need much more attention and a well designed organisational solution. Strong and responsive arrangements are required, with the Ministry of Finance playing a leading role in co-ordinating the views and actions of different ministries with interests in the EC budget. Usually, this also includes a clear overall responsibility for the government-wide development and implementation and of internal control standards and audit.

710. It is imperative for Member States to have effective procedures in place for co-ordinating the views of different ministries and other government agencies. The country papers show how essential it will be for the applicant countries to supplement their formal contacts with the Commission and Member States with close and continuing informal contacts at all technical levels as well as at senior official and political level. Negotiating a protocol on financial control and audit with the Commission is one means which an applicant country might use to build closer working relations with the Commission and, at the same time, deepen its understanding of the EU's financial control system.

711. In strengthening their financial control and external audit systems, the experience of existing Member States highlights the importance of developing an integrated and co-ordinated approach in which the relevant authorities in government, notably the Ministry of Finance, and the SAI should work closely together. This demands careful consideration not least because of the issue of independence of the SAI. An adaptable and flexible approach will be required to deal with the significant changes in EU budgetary and control systems that are likely to arise over the next few years as a result of modifications to the major EC expenditure funds (agriculture, structural adjustment, etc.) and, to the control system itself, through the SEM $2000^{44}$ exercise.

44. Sound and Efficient Management 2000. 
Chapter 11: Rebuilding the State:

Administrative Reform in Central and Eastern Europe

\author{
By Joachim Jens Hesse ${ }^{45}$
}

45. Joachim Jens Hesse is Professor, European Centre for Comparative Government and Public Policy, Berlin, Germany. 


\section{Introduction}

712. The countries of Central and Eastern Europe are still undergoing fundamental, if not revolutionary changes affecting the very foundations of their political, economic and social life. Although both the extent of the transformation processes that have thus far taken place and the pace differ considerably from country to country, it is no doubt possible to detect a number of shared characteristics which suggest a common pattern of change. The distinguishing features include: the transition of what were effectively, if not in name, systems of one-party rule, in which the leading role of the Communist Party in all sectors of society was firmly entrenched, to pluralist, parliamentary systems with democratically elected and accountable governments; the abandoning of the principle of "democratic centralism" in favour of a far-reaching deconcentration and decentralisation of political power to be exercised under the rule of law; the rejection of the principle of unity between politics and the economy, which involved the emergence of distinct spheres of political and economic life; and far-reaching economic reforms whose principle aims are the strengthening of private enterprise, the denationalisation (or rather privatisation) of a large share of the previously state-controlled productive capital and a substantial deregulation and liberalisation of the national economy.

713. The underlying ideas spurring the ambitious reform attempts at replacing a nationalised, centralised and planned economic system with a market economy are, in principle, also being applied to the task of re-organising or perhaps, rather, re-founding public administration. Thus, there are moves to strengthen democratic control over state administration to increase its accountability to democratically elected bodies; efforts are under way which aim at the deconcentration and decentralisation of the bureaucratic apparatus; the need to bring public institutions strictly under the rule of law and to guarantee the legality of public acts is stressed; and it is universally accepted that public efficiency, effectiveness and flexibility must be increased. All this implies that the organisation of governance is subject to the same pressures for change which have already led to radical political reforms, which transformed the economy profoundly and, partly by extension, revolutionised the fabric of society.

714. It is worth repeating, though, that the task of modernising public administration or the public sector at large goes much beyond subjecting it to the basic legal norms of conduct which govern the execution of public responsibilities in the majority of the industrialised countries of Western Europe. The challenge with which public institutions are faced in Central and Eastern Europe, is to redefine even their role in society, or, more concretely, their relationships with politics, the economy and the civil community. One is well advised, therefore, to recall that the dynamics of institutional transformation are intimately linked to changes in the political, legal, social and economic environments in which public institutions operate and on whose material and immaterial inputs they crucially depend. Although public administration is both an object of reform and, almost invariably, its chief agent, the reform process is an interactive one.

715. Acknowledging these contextual conditions, reforms have made considerable progress in overcoming understandable, but still damaging anti-state attitudes by stressing the positive contribution of a modernised public administration to a functioning market economy. In such an environment, the need for an inclusive approach at reform is generally accepted. This means that tasks, organisational structures, administrative procedures and issues of personnel are not to be considered in isolation. It also implies that horizontal and, in particular, vertical linkages and interdependencies between different levels of government are taken into account. Doing so, it becomes obvious that the contextual conditions under which the central and eastern European public sector operates are subject to a degree of change which has made large-scale adjustments inevitable. Although bureaucratic organisations are, of course, capable of absorbing considerable external "shocks" without having to resort to fundamental reforms, the 
unprecedented character of the central and eastern European transformation processes calls into question some of the most basic principles on which the administrative apparatus had been built. Public administration is, therefore, under tremendous pressure to adapt. As reform efforts aim at introducing stability, dependability and continuity into the administrative system they must, at the same time, not hamper later revisions and modifications, which are bound to be required as the environment continues to be transformed. Thus, stability needs to be combined with flexibility, dependability with openness, continuity with adaptability. Under such conditions, one needs to be careful in prescribing specific institutional, procedural and personnel arrangements or even an elaborate public management approach.

\section{Common Reform Trends}

716. Looking at the different stages of development, it might be possible, however, to identify some common trends that are to be distinguished in the central and eastern European reform process:

- During the initial phase of transformation the old legal, political, social and economic orders irrevocably broke down and new structures began to be formed. Characteristics of this transformation phase include: the emergence of multi-party systems; regular elections at the national, regional and local levels; the overhaul of public sector institutions, in some cases amounting to an attempt at recreating the entire governmental machinery; the formulation and partial implementation of what often were radical economic reform programmes; as well as thorough and in some cases heated constitutional debates. As all encompassing the developments appeared, the results were varied and often fragmentary. Volatile voting patterns, unstable coalitions and unresolved power struggles between different governmental institutions were as common as constitutional debates were inconclusive, privatisation programmes incomplete and institutional arrangements and re-arrangements short-lived.

- The initial transformation phase was followed slowly by what one could call a process of consolidation, during which increased political stability allowed for a more systematic approach to dé-étatisation, privatisation and marketisation. Whilst the demarcation between the executive and the legislative as well as that between the political and administrative spheres remained somewhat fuzzy, and whilst constitutional issues remained unsolved, the programmes of economic transformation began to show first encouraging results. Less erratic voting behaviour supported the expectation of continuity which proved to be necessary to stimulate and sustain private sector investment, and that also turned out to be conducive to a more rational approach at evaluating and reforming the public sector. As "big bang" approaches lost their appeal, designing and implementing crucial and more specific policies became the staple rule of the game.

- The said stability in turn allowed for at least a medium-term approach, instead of ad hoc measures, which - combined with enhanced problem awareness - led to the third phase of modernisation. The need to overhaul institutional arrangements and to look out for "best practice", not least triggered by the need to secure various policies, characterised this stage. Unresolved problems and newly emerging deficiencies suggested, finally, a redefinition of the public sector, its extent, role and institutional make-up. It became increasingly clear that marketisation and privatisation would in the long run only produce the hoped for results if based on a comprehensive and binding legal framework accompanied by the necessary safety provisions, checks and balances, and, if supported, regulated and controlled by an efficient and reliable public administration. Yet, the re-organisation of the machinery of central government as well as both the functional and territorial demarcation of competencies proved notoriously difficult undertakings. Added to this was a widespread problem of discontinuity 
in personnel, resulting on the one hand from the increased attractiveness of private sector employment, and from the practice of incoming governments to replace large fractions of the administrative leadership on the other. In some cases, the mentioned unresolved constitutional issues continued to hamper the modernisation process.

- A fourth and partly overlapping phase to be distinguished in the process of reforming public administration is that of adaptation towards the state of the art of public sector performance, as observed in Western environments, as well as towards the pressures brought about by the preparation for European Union membership. Ten of the thirteen countries working with the SIGMA Programme (Bulgaria, the Czech Republic, Estonia, Hungary, Latvia, Lithuania, Poland, Romania, Slovakia, Slovenia) have deposited their applications for membership at the Commission and have already concluded association agreements. The remainder is also working towards membership. The administrative capacities as well as the regulatory instruments (legal approximation) needed in order to cope with the acquis communautaire will require enormous legislative, institutional and procedural adjustments to be made by the applicant countries. Given that the extent to which these preparations have been made will be one of the determining factors in the European Union's decision on the opening of formal negotiations, this adaptation process has been given high priority in the countries concerned.

717. In distinguishing these phases or stages of transformation, consolidation, modernisation and adaptation, one has, of course, to be aware of their contingency when applied to thirteen such widely different contexts. The succession of these phases should, furthermore, not be taken to suggest a "logic", a time continuum, let alone a uniform experience within the countries working with the SIGMA Programme. Neither should different stages be distinguished merely depending on the respective developmental process; in each case they represent the outcome of different settings such as specific legacies, state traditions or indeed different administrative cultures. Instead, they may serve as broad categories wherein which all thirteen countries can be located. If the most advanced have gone through this typical development, the four phases might help to identify a kind of "state of the art" as far as the reform process and its constituent parts are concerned. This should not, however, be confused with convergence of the public administration systems of the thirteen, let alone with global convergence. Nonetheless, given that there are a number of important similarities in the external and internal challenges facing public administration in Central and Eastern Europe - and indeed in Western environments as well - it seems more than appropriate that international organisations should be involved in supporting the reform process.

\section{Institutional Issues at the Centre of Government}

718. As regards the contextual conditions of administrative reform, there are signs of an increasing consolidation. In the political sphere, the process of institutionalising a framework of democratic governance has been more or less concluded, and the main outlines of the future political order became increasingly evident. The unpredictability and uncertainty of political life which characterised the transition years is gradually declining, as more settled patterns of political behaviour evolve. As regards economic reconstruction, it is, of course, still far from being completed; the transition from socialist planning to marked-based economy through privatisation, liberalisation and marketisation has proved a much more complex and drawn-out process than many had originally predicted. Moreover, the disruptive effects of this reconstruction process, in terms of falling production, rising inflation, mushrooming unemployment or declining living standards, have been much more severe than the proponents of reform were initially ready to admit. However, whilst economic policy faces mounting problems, the basic structural foundations of the different national economies also begin to emerge more clearly. Generic 
declarations in favour of creating market-based economies are increasingly replaced by more differentiated policies. This concerns, for example: the role of publicly owned enterprises; the mix between small, medium-sized and large firms and corporations; or the sectoral composition of the economy. Here, a comparative analysis reveals significant policy differences between the countries working with the SIGMA Programme, even though they share basic commitments. At the same time, as the guiding objectives of economic reconstruction become more specific, and policies therefore more distinct, the creation of the legal institutions of a mature market system is progressing. For administrative development, the stabilisation of important variables of political and economic reform implies an increased degree of dependability and predictability. As the context of public administration begins to settle, political expectations and functional demands in the medium - and long-term become more apparent. Consequently, there is a more realistic chance for positive, purposive reform, which goes much beyond change via negationis, i.e. the rejection of the administrative inheritance of "democratic centralism".

719. As regards institutional issues, it is worth noting that in contrast to the intermediate/regional and local levels of public administration, reorganisation at the centre of government remained by and large restricted to structural adjustments that were immediately connected with democratisation and economic liberalisation. For the main part, these early adjustments focused on two areas: internal security and economic administration. It might come as a surprise that the extensive array of government departments and national offices, which form the core of the central machinery of government, has in many countries not yet been subject to a comprehensive reform. That is not to say, however, that no significant changes have taken place; nor does it mean that the need for a wholesale re-examination of the central institutions of governance has remained unacknowledged. However, political instability since the autumn of 1989 and uncertainty about the future role of central administration and its relationships with sub-central levels of government have prevented far-reaching reforms. Although this has changed profoundly in some cases over the last two years, there is still significant work to be done. In general, one witnesses broad agreement amongst policy-makers that a comprehensive restructuring of departmental competencies at the central level will only be possible once the future tasks of central administration have been defined more clearly. In other words, decisions are required on the scope of the future powers and responsibilities of the national administration as opposed to regional/provincial and local governance.

720. But however skilfully prepared and carefully monitored, the ultimate success of any modernisation programme depends crucially on the ability of reformers to overcome intra-organisational resistance to change. Here, administrative reform analysts would appear to agree almost unanimously that coercive strategies, relying on the exercise of power to push through reforms, are unlikely to produce the desired results. Instead, they stress the need to adopt an essentially persuasive approach, aimed at mobilising those belonging to the organisation to be reformed. Although it will be several years before the success of the modernisation process can be judged, the high degree of importance which is attached to administrative organisation at this level is encouraging.

\section{Intermediate/Regional Level of Government}

721. Turning to the intermediate/regional level of government, one is again able to detect a number of common characteristics in the countries of Central and Eastern Europe. This refers first of all to the uncertainty about the future of the intermediate level and intergovernmental arrangements at large. Whilst the previous district offices were abolished almost everywhere, since they served as organs of state government, the future of the regional level is still wide open. Although there is mostly consensus on the need for further structural change, as the current territorial organisation of state administration is widely seen as ineffective, there are only few successful reforms; several experiments failed. We still witness, 
therefore, a great deal of instability and confusion concerning the appropriate intermediate level in central and eastern European countries. Whereas the old intermediate authorities have been discredited and decisively weakened, the new ways promoted have led to a proliferation of specialised deconcentrated units of state administration. What emerges is an attempt to disentangle governmental levels, although there is growing awareness that problems of co-ordination and control might be at the forefront of the administrative reform process over the years to come. Owing to the multitude of institutions with partly overlapping competencies, it should not come as a surprise that tangible performance deficits tend to worry administrative reformers. All in all, intergovernmental arrangements and the intermediate level seem to have developed into a serious bottle-neck of the ongoing reform process. Since they serve as a key in implementing administrative policies, intermediate institutions undoubtedly deserve special consideration.

\section{Local Government}

722. In discussing the attempts to rebuild local government in Central and Eastern Europe, it is important to distinguish between the changes in the normative framework, on the one hand, and the actual practice of local government and administration, on the other. Although the reform legislation mostly adopted in 1990/91 is not free of internal contradictions and ambiguities and is partly in need of clarification and specification, it did provide a solid legal basis for the separation of state administration from local government. The concept of a "unified" or "homogeneous" state authority (in which local authorities act as representatives of central state government and are unequivocally sub-ordinate to central directives and control) was rejected and replaced by a dual system, in which state and local governments act within their own spheres of influence. In view of the recentness of some of the reforms and the in many cases still unstable constitutional, political, economic and social environments in which they have to be implemented, it should not come as a surprise that the reality of local government partly lags behind the normative ideal: Looking at the legal framework alone would, therefore, provide an incomplete and, in fact, distorted view of the state of local government.

723. Whilst local government reform legislation has, undoubtedly, greatly strengthened the role of the local level and succeeded in establishing a sphere of genuinely autonomous government, many argue that the reforms have shown too little appreciation of the need for active inter-governmental co-ordination and co-operation and integrated policy-making. Such criticisms appear partly justified, not least due to the lacking organisational and procedural capacities and the undoubtedly underdeveloped and highly sectoralised intergovernmental co-operation. The problems of sectoralisation are compounded by the fragmented nature of the local government map. Weak intermediate institutions mean that central bodies are increasingly required to try to build up direct links with local governments, a task made more difficult by the great number of local units and, especially in case of many small localities, the lack of professional capacity. Conversely, local governments cannot rely on the county councils to represent their interests at the central government level, but need to find alternative channels of access. As a result, the sectoralised and fragmented nature of intergovernmental relations is perpetuated.

724. However, the fragmentation of the local government level not only adversely affects intergovernmental co-ordination and co-operation, it also impairs local government's own administrative capabilities. Difficulties resulting from increased tasks, inexperience with the fundamentally altered political, legal and financial framework, and a lack of central guidance are magnified by the extreme deconcentration of governmental and administrative resources at the local level. One common objection to local government reform is that it has resulted in an atomised local tier incapable of performing its new functions efficiently and effectively. There can, indeed, be little doubt that many of the very small localities, with few or no professional staff and very limited financial resources, face great difficulties in 
carrying out their mandatory tasks and cannot take advantage of the considerable scope for local government action which the new legal framework affords.

725. It seems, therefore, as if reformers have placed too high hopes in local government reform. The very understandable emphasis on what one could call a "bottom-up" approach led to significant shortcomings: The capacities of local governments were partly over-estimated; conversely, there has been a significant underestimation of the need for central steering and control; eventually, the over-emphasised principle of local autonomy led to significant problems of intergovernmental co-ordination. As a result, there are growing calls for a partial "reform of the reform", seeking to adopt a more pragmatic approach towards local government.

\section{Civil Service}

726. Moving on to issues of personnel, public administration in the post-communist countries of Central and Eastern Europe has conventionally been depicted as vastly over-extended and over-staffed. Consequently, a drastic scaling-down of the public service through privatisation and massive redundancies are often considered inevitable consequences of the transition towards a modern public service, comparable in its tasks, structures and procedures to Western public administration. However, such an assessment is to be questioned on at least two grounds. First, it would seem to underestimate the large differences in the size of government employment which exist between the Western industrialised countries as well. The second objection to a simple cutback argument is based on the fact that it tends to overestimate the current size of public administration. Whilst the socialised sector of the economy did until very recently account for the overwhelming part of civilian employment, by far the largest proportion of this was made up for enterprises in state-ownership and co-operatives. By contrast, public administration itself is comparatively small. The quantitative challenge is not, therefore, found in core public administration, but in the socialised sector of the economy.

727. By far the greater challenge in reforming the personnel sector lies in addressing qualitative deficiencies. This requires the development of a reasonably coherent and sustained personnel policy, which takes into account the interdependence between its central elements, such as personnel recruitment, personnel utilisation, personnel motivation, staff representation, and personnel training and qualification. Until very recently, only few countries were able to formulate and implement policies which could be expected to result in major improvements in the personnel sector. The steps which have been taken were principally directed at alleviating some of the most pressing short-term difficulties, but have often failed to tackle more deep-seated structural problems. Moreover, there is little indication that in adopting measures concerning particular elements of personnel policy, sufficient thought has been given to their inter-linkages. In other words, isolated steps, without reference to a more comprehensive reform design, have predominated.

728. It is possible to identify several factors which have thus far prevented the emergence of a more comprehensive personnel policy. The most important is, perhaps, that the unified public service does, in quite a number of cases, not really exist; in fact, the idea of the public service as such, does not have a basis in law. As yet, there are only few civil service codes which aim at regulating the rights and duties of the public service; instead, most employees in public administration fall under the general labour law. Special regulations regarding labour relations only exist for parts of public administration (notably the internal security forces, the armed forces, the police and prison guards); for the most part the idea of uniform labour relations prevailed. The negative effects of this lack of a comprehensive legal framework to regulate employment in the public sector are compounded by the fact that there is often not a single employer. Rather than being employed by the state, employee's labour contracts are with individual 
government departments. This leads to a great deal of variance in contractual arrangements. The absence of a common legal framework for the public service and the independence of individual ministries in matters of personnel greatly impede the development of a coherent personnel policy. Moreover, until recently, the need for an organisational focus in government to consider personnel issues and to prepare reform legislation was scarcely recognised.

729. The passing of a civil service legislation is, therefore, rightly seen as a vital ingredient of the reform process. A stable, competitive, accountable and democratically reliable civil service is a pre-condition for success not only of administrative reform, but for political stability and economic development as well. Coping with the EU's acquis communautaire should serve as a further impetus to reform.

730. Increased political stability, improved economic performance and prospects as well as the growing expertise of public sector personnel are now beginning to combine to allow for a profound modernisation of public administration. In doing so, issues of implementation have come to the fore again. Here, it is important to note that viable implementation strategies for creating a responsive and accountable public administration and an effective system of rule of law have been dangerously underestimated during the early stages of the transformation process. In reforming constitutional law and secondary legislation, for example, the emphasis has firmly been on substantive issues; the normative content of legislative acts has been at the centre of the political and legal debates. By contrast, procedural aspects have tended to be neglected. In particular, the decisive questions of how constitutional and secondary law can be made effective, what difficulties may arise in the implementation process and how they could be minimised have not been addressed in a systematic manner. West-East knowledge transfer was of marginal help in this respect, as the efforts focused almost exclusively on assisting legislative activity (in particular the legal adaptation to a market economy). In fact, one may well argue that law-making was for a rather long period largely dissociated from its own implementation; new legislation was often adopted although it was recognised that the administrative preconditions for giving effect to these new laws were lacking and could not be created within a short period. Legislation, therefore, degenerated (and partly still degenerates) into symbolic politics. The resulting dangers should be obvious: The adoption of laws which cannot be enforced (or which legislators do not intend to see enforced) not only discredits the legislative process, but, in the longer term, also the very idea of a polity based on the rule of law.

731. In the rare cases where implementation issues have been given explicit consideration in the reform process, it would appear that the potential for a direct application of Western experiences was viewed too optimistically as well. Western experiences over the last two decades have undoubtedly helped to highlight the complex preconditions for giving effect to legal regulations and political decisions; to a certain extent they have also improved the capacity for designing more efficient implementation processes by identifying key actors and resources. However, the lessons drawn from Western experience seem of little immediate use in trying to improve implementation in Central and Eastern Europe. Western analyses have mostly focused on implementation in comparatively stable environments, whereas the normative frameworks in Central and Eastern Europe are, of course, still undergoing a process of dynamic change. More generally, the often still turbulent context in which implementation does (or does not) take place, means that few of the basic assumptions with which Western policy-makers and administrators are used to operate can directly be applied to the central and eastern European situation. That is why the reformers now rightly stress to build up the domestic potential to implement crucial policies; it is, once again, the process of recognising the own potential that is important in this respect.

732. As regards procedural questions, reference has already been made to the elusiveness of "global convergence", let alone that of a new "paradigm" in public administration reform. This has not, however, 
prevented "management gurus" or "academic tourists" from advocating their "products". Only now is it being recognised that within the environments of Central and Eastern Europe it needs "rowing" as well as "steering" to keep the boat afloat, as even the most attentive steering is conditional upon the day-to-day success of those implementing public policy. To go even further, the introduction of business approaches in public administration, as advocated by New Public Management concepts, may well prove disastrous in systems based on a continental European tradition in which either the preconditions may not be in place or where they may be rejected due to their inherent logic. Particularly problematic in the transformation context will be the all too limited ability of New Public Management systems to cushion the impact of unrestrained free market behaviour. At best, a drive towards improved management methods may be appropriate, while it appears impossible to simply adopt Anglo-Saxon administrative cultures. A note of caution is therefore appropriate: With regard to procedural issues, "recognising the own potential" has to be read as a recommendation rather than an identification of an already prevailing trend.

733. The creation of an efficient, accountable and reliable public service is, therefore, conditional upon a number of prerequisites, which, if ignored, may well cause appropriate individual reforms to remain ineffectual:

- The most basic, yet undoubtedly most consequential among these can be termed legal minima. Without a legal framework, provided for example by a comprehensive civil service law, it will be impossible to attract an élite into the public service. Confidence - particularly important as a determinant in individual career choices during transformation and modernisation processes - will only be ensured if employment duties as well as rights are guaranteed and made enforceable. A degree of flexibility which may have been appropriate during the earliest stages of reforming the machinery of government now hinders the development of the reliability and expertise required by modernisation and adaptation.

- In addition to confidence based on legal minima, there has to be broad political backing for public administration reform, as well as political will to see this effort through to its successful conclusion. Official and public acknowledgement of the importance of a solid, efficient and accountable public service to secure democratic government is essential not only in creating legitimacy, but therewith also in enhancing the social prestige of public sector employment. Once again, the historical experience of a discredited state apparatus suggests that an extra effort has to be made in this regard in order to attract qualified personnel.

- Motivation and long-term commitment of individuals to working in the public sector have to be ensured with the establishment of a career system. Only detailed job descriptions, institutionalised qualification requirements, and promotion prospects made calculable by equality of treatment and performance appraisals will allow for the degree of career planning necessary to enhance the attractiveness of continued civil service employment. A transparent pay structure and the possibility of performance related bonus-awards complete the list of incentives, the combination of which will significantly contribute to achieving the desired quality and continuity in the civil service. It is in this context that lessons can be drawn from Western models, albeit by negation rather than imitation. A successful implementation of a career system thus defined may well make the fledgling democracies leaders rather than followers in international comparison.

- A fourth and somewhat broader precondition for creating an efficient and successful public service is the incorporation of individual reform initiatives within an overall reform strategy. Of course, it may not be possible - perhaps not even advisable in view of on-going change and adaptation - to aim at a "once-and-for-all" definition of the size, shape, tasks and or- 
ganisational make-up of the public sector. Yet, rather than accepting disarray and flux as "inevitable" companions of transformation processes, some effort will have to be made to broadly define long-term objectives, so as to allow for individual reform initiatives to be formulated and implemented as part of an incremental and evolutionary, yet coherent, process.

\section{Conclusions}

734. Summing up, the following observations ought to be of interest in comparative perspective:

- Given the available evidence, attempts at generalising specific findings on administrative reform are made difficult by the simple fact that the countries of Central and Eastern Europe are still at very different stages of their administrative development. What is to be discerned are similar characteristics, but the national contexts, state traditions, administrative cultures are often too different to allow for comparable responses. Convergent problem structures may prevail, but it is differentiated responses which are called for. Given the time pressures under which association agreements have to be made fully operational in advance of EU negotiations, there is a danger to over-generalise the assistance requirements of individual countries.

- Examining different attempts at reform, a predominant mode is still one of "reform by announcement", "reform by legislation" and/or "reform by programme". One witnesses, therefore, a striking mismatch of intentions and factual outcomes/real changes. A closer look at the impact of individual reforms in different countries has confirmed the often misleading character of evaluations based exclusively on the drafting of legislative texts, the development of specific reform programmes and the multiplicity of official declarations.

- The further tendency to engage in "top-down" approaches at reform is accompanied by a rather asymmetric perception of the given needs. The according over-emphasis on issues of central government is complemented by an under-estimation of the need to build up regional capacities and to review the experiences made with the mostly very liberal local government legislation since 1989. This lack of acknowledgement has led to striking regional imbalances and a number of severe social disparities. This has by now been acknowledged, but the intricate issues of intergovernmental relations associated therewith do not seem to have been given the required attention. As mentioned, in many of the central and eastern European countries the relationships between central, regional and local governmental levels remain a crucial bottleneck in implementing reform policies. These circumstances are being aggravated by the fact that territorial and sectoral reform efforts rarely coincide.

- It furthermore appears that improved processes of co-ordination and co-operation are urgently needed. A specific characteristic of the countries under observation is not only that co-ordination, co-operation or even communication channels between and among ministries remain under-developed, but also that a basic understanding of the need to establish and maintain such processes with other levels of government is lacking. The inefficiency of many an ambitious public administration reform programme can be traced back to one of the continuing legacies of the communist past: State officials are not sufficiently aware of the need for both horizontal and vertical co-operation.

- General assistance programmes for public administration have certainly not yet lost their justification. In very many cases, basic administrative requirements are still not in place. In order to aim at a steady building up of a domestic body of expertise, such programmes should not, therefore, prematurely be discontinued but require sustained attention. That they remain 
crucial can be illustrated not least with reference to the situation in countries, where incoming governments face the task of re-examining basic governmental structures all over again. Valuable and costly sectoral or problem-specific initiatives are in danger of remaining ineffectual, if basic administrative capacities and/or expertise are still lacking.

- As regards issues of personnel, the attempts at improving pre-service and in-service training ought to be evaluated. It seems as if the policies pursued during the early stages of the transformation process have outlived their purpose. What appears necessary now is to provide a solid needs assessment for each country in order to target funds more effectively. "Mass-training" schemes threaten to become counter-productive in so far as the (often all-too young) representatives of consultancies do not provide the problem-specific information needed by now. This should not be taken to mean that general administrative skills are fully secured by now. Yet, the results of needs analyses should be used to target training to the remaining problem areas. Additionally, such analyses can be expected to uncover very specific problem-related skill requirements. Here, it is to be explored whether a policy of "twinning ministries" or better "twinning professionals" should be given priority.

- It has, furthermore, become apparent that the implementation of various policies has developed into a crucial bottleneck to the reform process. There is a growing awareness that it needs institutions as well as procedural know-how and qualified personnel to bring reforms to a successful conclusion. That, in turn, should encourage not only to complete horizontal reforms and to put further emphasis on sectoral policies, but also to reinforce attempts at improving the governance systems of the countries under consideration. In this respect, it would make sense to set up "focal points" for information exchange on administrative reform and related issues, especially in those countries which have not yet adopted a positive attitude towards institutional development and administrative stabilisation.

- In this context, it is once again necessary to recognise that public administration is both the subject and the object of reform. Issues of monitoring administrative performance and of enhancing control and accountability should not, therefore, be considered as being of negligible importance. Particular care has, for example, to be taken in formulating terms of reference for training efforts and other reform projects to a level of specificity which is necessary to allow for a meaningful qualitative assessment upon completion. That will, of course, also require a simultaneous strengthening of auditing capacities in the countries under consideration.

- "Learning by doing" no longer suffices for the reform needs of the countries under consideration; "learning from experience" is to be added. This refers not only to the help and assistance provided by "Western" environments, but also to the possibility of utilising the experiences made in neighbouring countries. Multi-country programmes, intra-regional co-operation and cross-border projects should, therefore, be accorded greater emphasis. The possibility of benefiting from the experience of others might add a stronger multilateral attitude to administrative reform than is to be detected so far. The cost-effectiveness of such attempts is to be stressed; respective policies are, therefore, to be encouraged by international organisations and bilateral donors.

- The capacities to absorb specific programmes seem to be rather unevenly distributed among the countries of Central and Eastern Europe. It might, therefore, be taken into account that further implementation proficiency is needed even in very specific policy areas. This, in turn, asks for a broader perspective to be applied in administrative reform, i.e. to acknowledge the interchange of organisational structures, procedural requirements, resources and personnel. 
- As regards external assistance, a tendency to "reinvent the wheel" is to be noted. While this is understandable in cases where some early assistance programmes failed (i.e. in the areas of civil service legislation or regional development), it might signal a misdirection of resources difficult to justify, considering the possibility to learn from experiences in other contexts. There is the danger that daily routines degenerate into the well-worn mode of "throwing money at problems".

- Despite different attempts at reform and changing priorities for assistance, there is hardly a coherent policy framework that would allow for longer-term, interlinked and mutually supportive assistance programmes. If costly duplication is to be avoided, the welcome attempts at decentralising initiatives in order to fully take account of specific circumstances, have to be supplemented by an overall framework of policy priorities to be followed, synergetic effects to be exploited and mutual learning processes to be enacted. While the divergence of administrative problems, political and economic circumstances as well as development potential necessitate some form of de-centralisation, it would be disastrous if unavoidable strategic guidance were to be neglected simultaneously.

- Donors so far show a mixture of first "supply-driven", then "demand-led", eventually "need-driven" and by now "accession-driven" approaches. This led to an element of confusion and counter-productive fluidity in the reform process.

- The lack of co-ordination between bilateral donors, international organisations and specific country projects has occasionally led to a duplication of efforts and a confused perception on the parts of the recipient countries. It ought to be mentioned here, that extended interviews with central and eastern European administrators have revealed a degree of resentment to frequently having to discuss the same issues with a number of different foreign delegates, receiving partly conflicting advice on different occasions. Clearer profiles and a sound division of labour seem to be needed. The different approaches of the donor institutions might be turned into an advantage, if the roles of strategic guidance and problem-solving advice are separated as far as possible.

- Concerning EU accession, the obvious link between legal approximation and public administration reform is to be acknowledged to a much greater extent than has so far been the case. It is to be ensured by the management process that individual programmes of these two strands do not remain unrelated on the ground. This refers to the need to utilise obvious institutional and procedural overlaps as well as to target training accordingly.

- In pursuing international assistance further, it might make sense - apart from concluding the general assistance programmes for public administration in crucial horizontal and sectoral areas of reform - to concentrate on the main elements of the pre-accession strategy, such as complementarity, additionality, conditionality and evaluation as well as on a further targeted and problem-specific programme development. Of course, it is one thing to refer to these issues, quite another thing, however, to secure those in the management process as well as on the ground.

- Finally, it is to be mentioned that multi-country programmes have demonstrated their value as flexible instruments that have certain advantages over single-country approaches. They facilitate the transfer of information, experience and "best practises" across borders. This allows comparative approaches to solving problems that are common to all participating countries. To counterbalance the decentralisation trends of country-specific programmes, the position of multi-country programmes could well be strengthened. 


\section{PARTICIPANTS LIST \\ (In English Only)}

Athens, 8-10 October 1997

(in alphabetical order by country, and then by individual)

\section{ALBANIA}

Mr Bujar Bala

Chief of EU Section

Ministry of Foreign Affairs

Dept for EuroAtlantic Cooperation

Boulevard "Jeanne d'Arc" No 6

Tirana

Mr Krenar Loloçi

Legal Adviser to the Prime Minister

Prime Minister's Office

Bulevardi Deshmoret E Kombit

Tirana

Mr Rustan Petrela

Director, Prime Minister's Office

Department of Public Administration

Bulevardi Deshmoret et Kombit

Tirana

\section{BULGARIA}

Mr Ivo Draganov

Adviser to Deputy Prime Minister and

Minister of Education

Council of Ministers

Dondukov Blvd. 1

1000 Sofia

Ms Zlatina Nikolova

Head of Chancellery Department

Council of Ministers

Dondukov Blvd. 1

1000 Sofia

Ms Jasmine Popova

Head of the European Integration Dept

Ministry of Foreign Affairs

2 Ul. al. Zhendov

BG-1113 Sofia tel: (355 42) 62065

fax: (355 42) 62084/2085

tel: (355 42) 35398

fax: (355 42) 28498

tel: (355 42) 30846

fax: (355 42) 28498

tel: (359 2) 8872068

fax: (359 2) 9811736

tel: (359 2) 9814964

fax: (359 2) 882726

tel: (359 2) 737412

fax: (359 2) 707589 


\section{CZECH REPUBLIC}

Mrs Petra Bartáková

Department for Coordination of

Relations with EU

Ministry of Foreign Affairs

Loretánské námesti 5

11800 Prague

Mr Petr Kubernát

Director, Department for Coordination of

Relations with EU

Ministry of Foreign Affairs

Loretánské námesti 5

11800 Prague

Mrs Eva Pauknerová

Advisor to the Prime Minister

Office of the Prime Minister

Nabrezi Edvarda Benese 4

11800 Prague 1

\section{ESTONIA}

Mr Henrik Hololei

Head of Office of European Integration

State Chancellery

Lossi Plats 1A

EE 0100 Tallinn

Ms Mari Pedak

Department Head

Local Government and Regional Development

Ministry of Internal Affairs

Pikk 57

EE-0001 Tallinn

Mr Aivar Rahno

Assistant to the Secretary of State

State Chancellery

Lossi Plats 1A

EE 0100 Tallinn tel: (420 2) 24182513

fax: (420 2) 24182046

tel: (420 2) 24182175

fax: (420 2) 24182046

e-mail: s_okeu@mzv.cz

tel: (420 2) 2900563

fax: (420 2) 24002317

e-mail:pauknero@vlada.cz tel: (372) 6316721

fax: (372) 6316724

e-mail: henrik@wp.rk.ee

tel: (372) 6125100

fax: (372) 6125101

e-mail: mari@sisemin.gov.ee

tel: (372) 6316749

fax: (372) 6316994

e-mail: aivar@wp.rk.ee 


\section{"FORMER YUGOSLAV REPUBLIC OF MACEDONIA"}

Mr Plamen Georgievski

Assistant Minister of Justice

Ministry of Justice

"Veljko Vlahovic" bb

91000 Skopje

Mr Idjet Memeti

Deputy-Secretary of the Government

Expert Service of the Government

bul. "Ilenden" bb

91000 Skopje

Mr Dragan Tilev

Head of the Aid Co-ordination Unit

bul Ilinden bb

91000 Skopje

\section{HUNGARY}

Mr Zsolt Becsey

tel: (36 1) 4581075

Director

State Secretariat for Integration

Ministry of Foreign Affairs

Bem Rakpart 47

H-1027 Budapest

Mr Endre Kovács

Senior Advisor

International Department

Ministry of the Interior

XII Németvölgyi út 41

H-1903 Budapest

Mr Imre Verebelyi

Government Commissioner for

Modernisation of Public Administration

Kossuth Ter 4

H-1055 Budapest tel: (389 91) 230-723

fax: (389 91) 226-975

tel: (389 91) 115-239

fax: (389 91) 113-710

tel: (389 91) 239165

fax: (389 91) 113710 tel: (36 1) 2662645

fax: (36 1) 2663048

tel: (36 1) 2683200

fax: (36 1) 2683202 


\section{LATVIA}

Mr Edvins Andersons

Director

Project Management Department

State Chancellery

36 Brivibas Blvd

LV-1050 Riga

Ms Solvita Harbacevica

Deputy Director

European Integration Bureau

Elizabetes 57

LV-1050 Riga

Mrs Svetlana Proskurovska

Director

Bureau of Public Administration Reform

Raina Bulv. 4

LV-1050 Riga

\section{LITHUANIA}

Ms Teresélé Kazlauskiené

Deputy Minister

Ministry of Public Administration Reforms and Local Authorities

Gedimino Ave 11

2022 Vilnius

Mr Adolfas Savicius

Government Secretary

The Prime Minister's Office

Gedimino Ave 11

2022 Vilnius

Mr Virgilijus Savickas

Adviser to the Prime Minister

The Prime Minister's Office

Gedimino Ave 11

2022 Vilnius tel: (371) 7284447

fax: (371) 7213505

tel: (371) 7286672

fax: (371) 7287904

e-mail: eib@eib.gov.lv

tel: (371) 7223109

fax: (371) 7223148

e-mail: bpar@com.latnet.lv tel: (370 2) 620110

fax: (370 2) 226935

tel: (370 2) 626595

fax: (370 2) 221088

tel: (370 2) 627041

fax: (370 2) 619953

e-mail: v.savickas@ervk.lt 


\section{NETHERLANDS}

Mr Jos van der Steen

tel: (31 70) 3027078

Senior Adviser

fax: (31 70) 3027634

International Affairs

Ministry of Interior

Schedeldoekshaven 200

2500 EA The Hague

\section{POLAND}

Mr Wiktor Marek Anselm

Director of the Department for Accession Negotiations

tel: (48 22) 6946719

Office of the Committee for European Integration

fax: (48 22) 6946988

Al. Ujazdowskie 9

00-583 Warsaw

Ms Izabella Dudzin

Director General of the Chancellery

tel: (48 22) 6287870

of the Prime Minister

fax: (48 22) 6947296

$1 / 3$ Al. Ujazdowskie

00-583 Warsaw

Ms Elwira Kucharska

tel: (48 22) 6949327

Director General of the Office of the

fax: (48 22) 6946988

Committee for European Integration

Al. Ujazdowskie 9

00-583 Warsaw

\section{ROMANIA}

Mr Grigore Lapusanu

tel: (40 1) 6595090

State Secretary, Chief of the Department

fax: (40 1) 3113641

for Local Public Administration

Piata Victoriei 1

71201 Bucharest

Mr Florin Lupescu

tel: (40 1) 222 3692, 2225470

Director

Department for European Integration

fax: (40 1) 2225470

Directorate for Institutional Cooperation

e-mail: uca@mail.kappa.ro

Victoria Palace, Victoria Square 1

Bucharest 
Mr Laurentiu Tachiciu

Secretary of State for Reform

Council for Reform

Department for Economic Reform

Piata Victoriei 1

71201 Bucharest

\section{SLOVAKIA}

Mr Stanislav Becica

Head of Minister's Office

Ministry of Interior

Pribinova 2

81272 Bratislava

Mr Frantisek Pauliny

Director

International Cooperation Department

Ministry of Interior

Drienova 22

81272 Bratislava

Mr Jaromir Turanec

Executive Assistant

Department for European Integration

Government Office of the Slovak Republic

Namestie Slobody 1

81370 Bratislava

\section{SLOVENIA}

Mr Zarko Bogunovic

State Undersecretary

Chief of Cabinet of the Minister of Interior

Ministry of Interior

Stefanova 2

61000 Ljubljana

Mr Peter Jeglic

State UnderSecretary

Ministry of Interior

Beethovna 3

61000 Ljubljana tel: (40 1) 2225973

fax: (40 1) 2223691

tel: (421 7) 321166

fax: (421 7) 362222

tel: (421 7) 234142

fax: (421 7) 235857

tel: (421 7) 5314461,5333689

fax: (421 7) 5333838

tel: (386 61) 217735

fax: (386 61) 302308

tel: (386 61) 1724273

fax: (386 61) 1251486

fax: (386 61) 1724253 
Ms Tatjana Koselj

Adviser

Office for European Affairs

Slovenska 27

61000 Ljubljana

(from 13/10/97: PM Cabinet

Counsellor for European Affairs)

\section{GREECE (Host country)}

Mr Vassilis Andronopoulos

Director General

Directorate General for Personnel Matters

Secretariat General for Public Administration

Ministry of the Interior

Public Administration and Decentralisation

15 Vassilssis Sofias Ave

10674 Athens

Mr. Stavros Benos

Deputy Minister

Ministry of the Interior

Public Administration and Decentralisation

15 Vassilssis Sofias Av.

10674 Athens

Mr Christos Boursanidis

Advisor to Education and Research

National Center of Public Administration

Pireos and Thrakis 2

17778 Tavros, Athens

Mrs Irini Bovoli

National Center of Public Administration

Pireos and Thrakis 2

17778 Tavros, Athens

Mrs Alexandros Denezakos

Lawyer, Special Scientific Advisor

Directorate General of Administrative Modernisation

Secretariat General for Public Administration

Ministry of the Interior

Public Administration and Decentralisation

15 Vassilssis Sofias Ave

10674 Athens tel: (386 61) 1781101

fax: (386 61) 1781101 tel: (30 1) 3393311

fax: (30 1) 3393300

tel: (30 1) 3496244

fax: (30 1) 3428049

tel: (30 1) 3496273

fax: (30 1) 3428049

tel: (30 1) 3333337

fax: (30 1) 3393300 
Mrs Maria Diamantopoulou

First Secretary of Embassy

Office of the Secretary General for European

Affairs, Ministry of Foreign Affairs

1 Vassilissis Sofias Ave

10674 Athens

Mrs Anna Giobre

Lawyer

Unit of Community Legal Affairs

Ministry of National Economy

Platia Syntagmatos

Athens

Mrs Vissaria Griva, Director

Directorate of International Affairs

Secretariat General for Public Administration

Ministry of the Interior

Public Administration and Decentralisation

15 Vassilssis Sofias Ave

10674 Athens

Mr Antonis Kaltsounis

Advisor to Education and Research

National Center of Public Administration

Pireos and Thrakis 2

17778 Tavros, Athens

Mr Themistoklis Kouroussopoulos

Honorary President of the Council of the State

President of the National Center of Public Administration

Pireos and Thrakis 2

17778 Tavros, Athens

Mrs Maria Lekka

Secretariat General of Public Works

182 Charilaou Trikoupi Str

10178 Athens

Mr Nikiphoros Manolas

Council of Economic Advisers

Ministry of National Economy

Platia Syntagmatos

Athens

Mrs Vassiliki Mesthaneos

Advisor to Education and Research

National Center of Public Administration

Pireos and Thrakis 2

17778 Tavros, Athens tel: (30 1) 3394017

fax: (30 1) 3394201

tel: (30 1) 3332341

fax: (30 1) 3332130

tel: (30 1) 3393478

fax: (30 1) 3393427

tel: (30 1) 3496211

fax: (30 1) 3428049

tel: (30 1) 3496201

fax: (30 1) 3428015

tel: (30 1) 6442090

fax: (30 1) 6442090

tel: (30 1) 3332545

fax: (30 1) 3332527

e-mail: soe1@athena.compulink.gr 
Mrs Georgia Michalakakou-Rokana

tel: (30 1) 3627810

Research Fellow

fax: (30 1) 3611136

Centre of Planning and Economic Research

22, Ippocratous Street

10680 Athens

Mr Sarantis Pantelias

Advisor to the Minister of Environment, Urban

Development and Public Works

182 Charilaou Trikoupi Str

10178 Athens

Mrs Anastassia Papastilianou

Head of Informatics Department

National Center of Public Administration

Pireos and Thrakis 2

17778 Tavros, Athens

Mrs Maria Politopoulou

tel: (30 1) 3393341

Director

Directorate for Administration and Finance

fax: (30 1) 3393390

Secretariat General for Public Administration

Ministry of the Interior

Public Administration and Decentralisation

15 Vassilssis Sofias Ave

10674 Athens

Mrs Aikaterini Polychronaki

Advisor to Education and Research

tel: (30 1) 3496270

fax: (30 1) 3428049

National Center of Public Administration

Pireos and Thrakis 2

17778 Tavros, Athens

Mrs Nelli Sakellariadou

tel: (30 1) 6449502

fax: (30 1) 6449502

tel: (30 1) 3496279

fax: (30 1) 3428049

e-mail: ideplhol.gr

Special Scientific Advisor

Ministry Coordinator for SIGMA Programme

Directorate General of Administrative Modernisation

Secretariat General for Public Administration

Ministry of the Interior

Public Administration and Decentralisation

15 Vassilssis Sofias Ave

10674 Athens

Mrs Vassiliki Sakellariou

tel: (30 1) 3313648

Director

fax: (30 1) 3313650

Directorate of Coordination and

Implementation of Public Accounting

Regulations

General Accounting Office

Ministry of Finance

23, Lekka Street

Athens 
Mrs Alkaterini Samoni

Legal Advisor

Head of the Special Legal Service of European Matters

Ministry of Foreign Affairs

1, Vassilissis Sofias Ave

10674 Athens

Mrs Vassiliki Sarantopoulou

Director General

Directorate General of Administrative

Modernisation

Secretariat General for Public Administration

Ministry of the Interior

Public Administration and Decentralisation

15 Vassilssis Sofias Ave

10674 Athens

Mr Vincenzo Scordamaglia

Honorary DG of the Council of the

European Union

61 Keas Street

11255 Athens

Mr Dimitrios Sfikas

Director

Directorate for Organisational Development

Secretariat General for Public Administration

Ministry of the Interior

Public Administration and Decentralisation

15 Vassilssis Sofias Ave

10674 Athens

Mr George Siolavos

Director General

Ministry of Development

Platia Kanigos

Athens

Mrs Calliope Spanou

Assistant Professor, University of Athens

Advisor to the Minister of the Interior

Public Administration and Decentralisation

77 Mavromichali Street

10680 Athens

Mr Photis Spathopoulos

Lawyer, Head of Unit of Community Legal Affairs

Ministry of National Economy

Platia Syntagmatos, Athens tel: (30 1) 3394097

fax: (30 1) 3394202

tel: (30 1) 3393496

fax: (30 1) 3393300

tel: (30 1) 2281016

tel: (30 1) 3393131

fax: (30 1) 3393100

tel: (30 1) 3817159

fax: (30 1) 3821707

tel: (30 1) 3602560

fax: (30 1) 3602560

tel: (30 1) 3332341

fax: (30 1) 3332130 
Mrs Ermioni Tavernari

tel: (30 1) 3332638

Chief of Division

fax: (30 1) 3332760

Directorate General of Economic Policy

Directorate of EU Relations

Ministry of National Economy

Platia Syntagmatos

Athens

Mrs Vassiliki Tselenti

tel: (30 1) 3393499

Director

fax: (30 1) 3393427

Directorate of Administrative Reforms

Secretariat General for Public Administration

Ministry of the Interior

Public Administration and Decentralisation

15 Vassilssis Sofias Ave

10674 Athens

Mrs Helen Verikaki

Directorate of International Affairs

tel: (30 1) 3393568

Secretariat General for Public Administration

fax: (30 1) 3393427

Ministry of the Interior

Public Administration and Decentralisation

15 Vassilssis Sofias Ave

10674 Athens

Mrs Stamatina Vodina

Lawyer, Special Scientific Advisor

Legal Service of European Matters

Ministry of Foreign Affairs

1, Vassilissis Sofias Ave

10674 Athens

Mrs Maria Zaoussi

Unit of Phare/TACIS Programmes

tel: (30 1) 3286236

Directorate of Relations with Eastern European

fax: (30 1) 3286234

and Balkan Countries

Ministry of National Economy

Kornarou 1 and Ermou

10563 Athens

tel: (30 1) 3394100

fax: (30 1) 3394202 


\section{EUROPEAN COMMISSION}

Ms Carolyn Leffler-Roth

Task Manager (DG1A/B5)

European Commission SC27 2/5

200 rue de la Loi

B-1049 Bruxelles, Belgique

Mr G. Zavvos

Counsellor

Directorate General 1A

European Commission

200 rue de la Loi

B-1049 Bruxelles. Belgique

\section{EXPERTS}

Mr Hans Brunmayr

Deputy Director General

DGF

Council of European Union

175 rue de la loi

1048 Bruxelles, Belgium

Mr Francisco Granell

Director, DG8

European Commission

200 rue de la Loi

1000 Bruxelles, Belgium

Professor Joachim Jens Hesse

European Centre for Comparative

Government and Public Policy

Rheinbabenallee 49

D-14199 Berlin, Germany

Dr Vitor Martins

former Secretary of State for European Affairs

ave Sidónio Pais $24-3 \mathrm{E}$

1050 Lisboa, Portugal

Professor Les Metcalfe

EIPA, O.L. Vrouweplein 22

NL-6201 BE Maastricht, The Netherlands

Professor Anargyros Passas

Secretary-General of the

National Center of Public Administration

17 konstantinopoleos str

151 2L Athens, Greece tel: (32 2) 2967470

fax: (32 2) 2968040

tel: (32 2) 2995659

fax: (32 2) 2993861

tel: (32 2) 2859197

fax: (32 2) 2857934

tel: (32 2) 29998 54/53

fax: (32 2) 2992905

tel: (49 30) 8417510

fax: (49 30) 84175111

tel: (351 1) 3528511

fax: (351 1) 3533812

tel: (43 3) 296222

fax: (43 3) 214237

tel: (30 1) 6122021

fax: (30 1) 6122021 
Professeur Jean-Louis Quermonne

Professeur émérité des Universités

6 allée de la Roseraie

38240 Meylan, France

Ambassador Byron Theodoropoulos

Former Secretary General at the Foreign

Ministry and Head of the Negotiating Team

for Greece's accession to the EU

Athens, Greece

\section{SIGMA STAFF}

Mr Richard Allen

Senior Counsellor

Budgeting and Resource Allocation

Ms Michal Ben-Gera

Principal Administrator

Policy-Making, Co-ordination and Regulation

Mr Bob Bonwitt

Head of SIGMA Programme

Ms Linda Duboscq

Project Coordinator

Policy-Making, Co-ordination and Regulation

Mr Jacques Fournier

Senior Counsellor

Policy-Making, Co-ordination and Regulation

Mr Kjell Larsson

Senior Counsellor

Administrative Oversight, Financial Control and Audit

Ms Winnie Marshall

Project Assistant

Policy-Making, Co-ordination and Regulation

Mr Staffan Synnerström

Senior Counsellor

Public Service Management

Mr Tony Verheijen

Administrator

Policy-Making, Co-ordination and Regulation tel: (33 4) 76410123

fax: (33 4) 76826070

tel: (30 1) 3605392 tel: (33 1) 45241300

fax: (33 1) 45241301

tel: (33 1) 45241398

fax: (33 1) 45241305

tel: (33 1) 45241310

fax: (33 1) 45241300

tel: (33 1) 45241317

fax: (33 1) 45241305

tel: (33 1) 45241308

fax: (33 1) 45241305

tel: (33 1) 45241373

fax: (33 1) 45241300

tel: (33 1) 45241308

fax: (33 1) 45241305

tel: (33 1) 45241315

fax: (33 1) 45241305

tel: (33 1) 45241313

fax: (33 1) 45241305 